IN A TWO-FOOT-SQUARE PILOT PLANT CALCINER
PROCESS FOR ALUMINUM NITRATE WASTES
PART I. EQUIPMENT DEVELOPMENT AND INITIAL PROCESS STUDIES

B. P. Brown, E. S. Grimmett, and J. A. Buckham

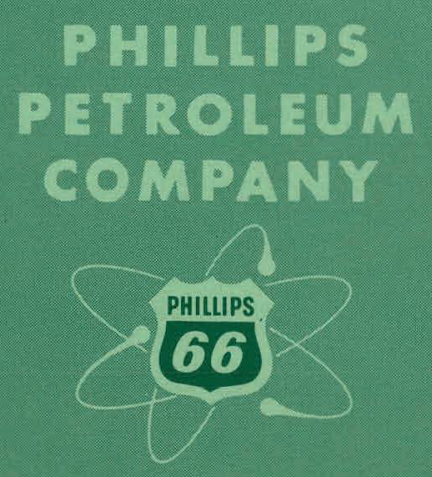

ATOMIC ENERGY DIVISION

NATIONAL REACTOR TESTING STATION US ATOMIC ENERCY COMMISSION 


\section{DISCLAIMER}

This report was prepared as an account of work sponsored by an agency of the United States Government. Neither the United States Government nor any agency Thereof, nor any of their employees, makes any warranty, express or implied, or assumes any legal liability or responsibility for the accuracy, completeness, or usefulness of any information, apparatus, product, or process disclosed, or represents that its use would not infringe privately owned rights. Reference herein to any specific commercial product, process, or service by trade name, trademark, manufacturer, or otherwise does not necessarily constitute or imply its endorsement, recommendation, or favoring by the United States Government or any agency thereof. The views and opinions of authors expressed herein do not necessarily state or reflect those of the United States Government or any agency thereof. 


\section{DISCLAIMER}

Portions of this document may be illegible in electronic image products. Images are produced from the best available original document. 
PRICE $\$ 2.25$

\author{
Available from the \\ Office of Technical Services \\ U. S. Department of Commerce \\ Washington 25 , D. C.
}

\title{
LEGAL NOTICE
}

This report was prepared as an account of Government sponsored work. Neither the United States, nor the Commission, nor any person acting on behalf of the Commission:

A. Makes any warranty or representation, express or implied, with respect to the accuracy, completeness, or usefulness of the information contained in this report, or that the use of any information, apparatus, method, or process disclosed in this report may not infringe privately owned rights; or

B. Assumes any liabilities with respect to the use of, or for damages resulting from the use of any information, apparatus, method, or process disclosed in this report.

As used in the above, "person acting on behalf of the Commission" includes any employee or contractor of the Commission, or employee of such contractor, to the extent that such employee or contractor of the Commission, or employee of such contractor prepares, disseminates, or provides access to, any information pursuant to his employment or contract with the Commission, or his employment with such contractor. 


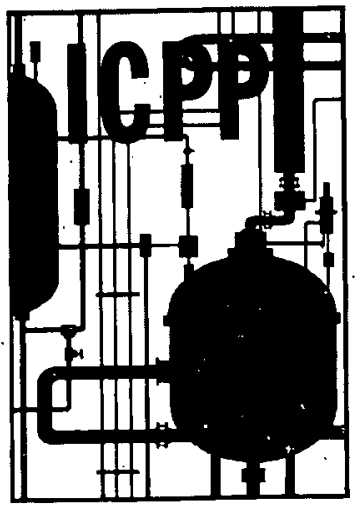

IDO-14586

AEC Research and Development Report Waste Disposal and Processing TID-4500, Edition 17 Issued: June 20, 1962

DEVELOPMENT OF A FLUIDIZED BED CALCINATION PROCESS FOR ALUMINUM NITRATE WASTES IN A TWO-FOOT-SQUARE PILOT PLANT CALCINER

PART I. EQUIPMENT DEVELOPMENT AND INITIAL PROCESS STUDIES

B. P. Brown

E. S. Grimmett

J. A. Buckham

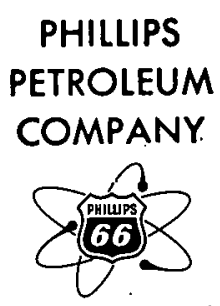

Atomic Energy Division

Contract AT (10.1).205

Idaho Operations Office

U.S. ATOMIC ENERGY COMMISSION 


\section{PAGES 2 to 4 WERE INTENTIONALLY LEFT BLANK}


DEVELOPMENT OF A FLUIDIZED BED CALCINATION PROCESS FOR ALUMINUM NITRATE WASTES IN A TWO-FOOT-SQUARE PILOT PLANT CALCINER

PART I. EQUIPMENT DEVELOPMENT AND INITIAL PROCESS STUDIES

$$
\begin{aligned}
& \text { B. P. Brown } \\
& \text { E. S. Grimmett } \\
& \text { J. A. Buckham }
\end{aligned}
$$

A two-foot-square fluidized bed calciner was designed and operated to further the development of a process to convert aqueous, highly radioactive wastes into granular solids. The calciner exceeded somewhat its designed feed capacity of calcining, at a bed temperature of $400^{\circ} \mathrm{C}$, 100 liters per hour of aluminum nitrate solution simulating wastes from the reprocessing of spent aluminum-uranium alloy reactor fuel.

Heat was supplied to the calciner by circulating NaK with an electromagnetic pump, at temperatures up to $1400^{\circ} \mathrm{F}$, through a tubular heat exchanger placed directly in the fluidized bed of solids.

The results of ten extended runs made in the calciner are presented and discussed. Equipment development progressed to the point where a continuous, trouble-free, operating period of 43 days was attained. Several properties of the alumina product were routinely measured, and some of the effects of the calciner operating variables on these properties were determined. The production of both amorphous and alpha crystalline material was found to be possible; the crystalline nature of the product had a profound effect on product properties and off-gas loading. 


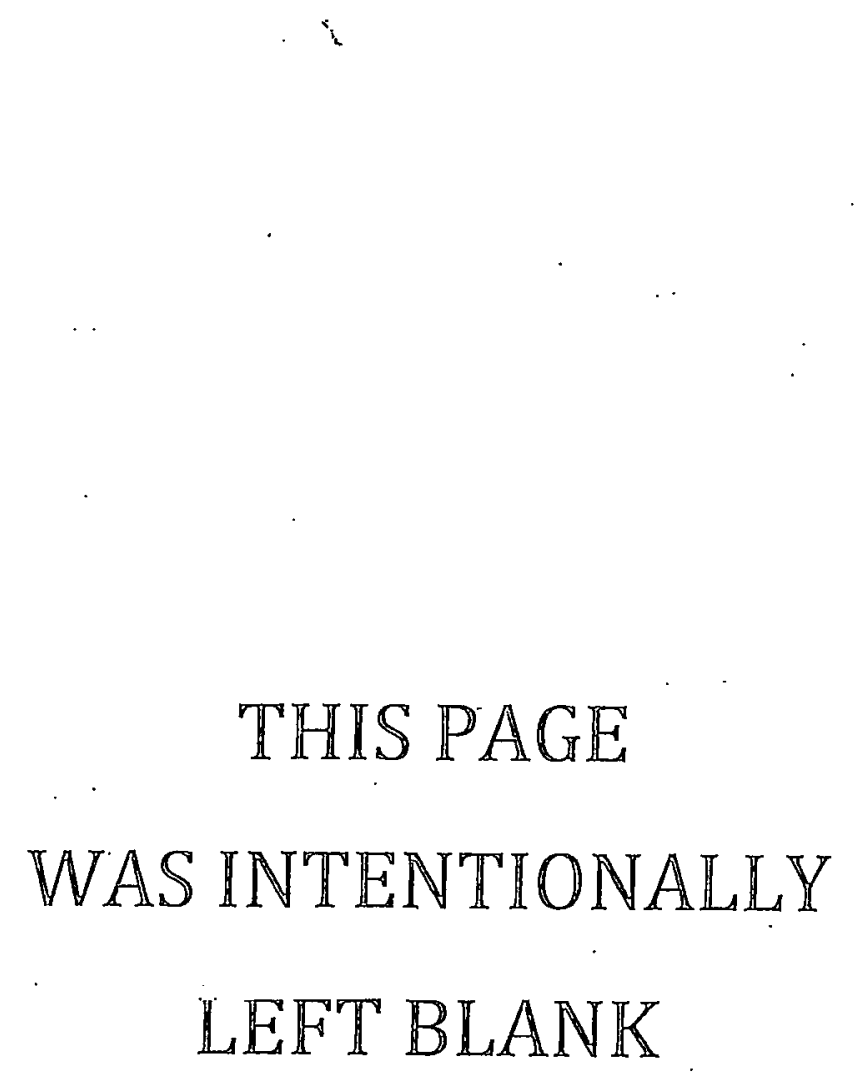


DEVELOPMENT OF A FLUIDIZED BED CALCINATION PROCESS FOR ALLMINUM NITRATE WASTES IN A TWO-FOOT-SQUARE PILOT PLANT CALCINER

PART. I. EQUIPMENT DEVELOPMENT AND INITIAL PROCESS STUDIES

TABLE OF CONTENTS

Page

I. SUMMARY . . . . . . . . . . . . . . . . 13

II. INIRODUCTION. . . . . . . . . . . . . . 15

A. The Fluidized Bed Calcination Process ....... 15

B. Previous Fluidized Bed Calcination Studies. . . . . 16

C. Need for Additional Studies . . . . . . . . 17

III. EQUTPMENT . . . . . . . . . . . . . . . . 19

A. Calciner Vessel . . . . . . . . . . . 19

1. Air Distributor Plate . . . . . . . . . 19

2. Product Removal System. . . . . ...... 21

3. Feed Nozzle Location. . . . . . . ... 21

4. Pressure Probes .............. 21

5. Gasket Materials............ 21

B. Off-Gas Cleanup System... . . . . . . . . . 22

1. Primary Cyclone . . . . . . . . . . . . 22

2. Fines Return Air-Jet Pump . . ...... . . . 22

3. Venturi Scrubber and Demister Cyclone..... 23

4. Off-Gas Condenser ............. 23

5. Scrub System................ 23

c. Heating Systems . . . . . . . . . . . 23

1. NaK System................. 23

2. Preliminary Systems............. 24

3. Fluidizing Gas Preheater. . . . ..... 25

D. Feed System . . . . . . . . . . . . 25

E. Process Control .. . . . . . . . . . 26

F. Equipment Cleanout. ............. 26

IV. INITIAL PROCESS STUDIES . . . . . . . . . . . . 29

A. Observed Operating Variable Ranges. . . . . . . . 29 
IV. INITIAL PROCESS STUDIES (continued)

A. Observed Operating Variable Ranges (continued)

1. Feed Composition............ . 30

2. Calciner Capacity. . . . . . . . . . . 30

3. Superficial Fluidizing Velocity. . . . . . 30

4. Feed Nozzle Air. . . . . . . . . . 32

B. Product Properties . . . . . . . . . . . 32

1. Product Particle Size Distribution .... . . 33

2. Product Bulk Density ............ 34

3. Absolute Material Density. . . . . . . . 35

1. Apparent Particle Lleneity. . . . . . . . . . . , 35

5. Intra-Particle Porosity. . . . . . . . 36

6. Product Nitrate Content. . . . . . . . 36

7. Product Hardness . . . . . . . . . . . 37

8. Structure of Calcined Alumina. . . . . . . 37

C. Dependent Operating Variables. . . . . . . 39

1. Heat Transfer Coefficients . . . . . . . 39

2. Fluidized Bed Weight... . . . . . . . 40

3. Fluidized Bed Height.... . . . . . . . . 40

4. Fluidized Bed Density. . . . . . . . . . 40

5. Product Rate and Theoretical Production Rate . . 40

6. Time Required for 90 Per Cent Bed Replacement. . 40

7. Solids Leaving with the Scrub Solution.... . 41

D. Effect of Operating Variables on Product Properties. 41

E. Comparison of In-Bed Samples with Overflow Product : 42

1. In-Bea Samples Taken Durlng Runs . . . . . . . 42

2. Samples Taken from Bed After Run Termination . . 42

V. CONCLUSIONS. . . . . . . . . . . . . . . 44

VI. ACINOWLDOMENTC. . . . . . . . . . . . . 4.7

VII. LITERATURE CITED . . . . . . . . . . . . . 48

VIII. APPENDIX . . . . . . . . . . . . . . 49

A. Detailed Description of NaK Heating System . . . 49

1. System Description ........... 49

2. Operating Problems........... 50 
VIII. APPENDIX (continued)

B. Run Data Summary.............. 51

$\operatorname{Run} 1 . . \cdot . \cdot . \cdot . \cdot . \cdot . \cdot 052$

$\operatorname{Run} 2 . \cdot . \cdot . \cdot . \cdot . \cdot . \cdot . \cdot . \cdot . \cdot . \cdot .65$

$\operatorname{Run} 3 . . . . . . . . . . . . . . . .668$

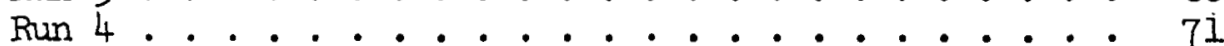

$\operatorname{Run} 5 . . . . . . . . . . . . .978$

$\operatorname{Run} 6 . . \cdot . \cdot . \cdot . \cdot . \cdot . \cdot . \cdot . \cdot 179$

$\operatorname{Run} 7 . . . . . . . . . . . . . .987$

$\operatorname{Run} 8 .$. . . . . . . . . ...... 88

$\operatorname{Run} 9 . \cdot . \cdot . \cdot . \cdot . \cdot . \cdot . \cdot . \cdot . \cdot 95$

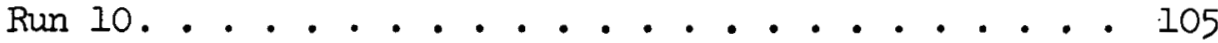

LIST OF TABLES

Table

1 The Effect of the Feed Spray Nozzle Operating

Conditions on the Production of 'F'ines in the

Two-Foot-Square Calciner. . . . . . . . . . 33

2 Relationship Between the Alpha Alumina Content of the Product and Presence of Sodium in the Feed. . . 38

3 Effect of Calciner Operating Variables on the Calciner Product Properties .. . . . . . . . . . 41

4 Comparison of In-Bed Samples with Overflow Product. . . 42

5 A Comparison of In-Bed Samples with Product Samples on Run 10 . . . . . . . . . . . . . . 43

\section{LIST OF FIGURES}

\section{Figure}

1 Schematic Diagram of Two-Foot-Square Pilot Plant

Fluidized Bed Calciner System . . . . . . . . 16

2 Calciner Vessel Details . . . . . . . . . . 19

3 Air Distributor Plate Used Subsequent to Run 6. . . 20 
4 Initial Air Distributor Plate . . . . . . . . 20

5 NaK Heating System.............. 24

6 Tube-Side-Fired Heat Exchanger. . . . . . . . 25

7 Calciner Process Control Polnts . . . . . . . . 27

8 In-Bed Product Sampler. . . . . . . . . 28

9. Two-Foot-Square Calciner Capacity ........ . 31

10 Relationship Between Bulk and Apparent Particle Densities of Calcined Alumina......... 36

11 Observed Fluidized Bed Heat Transfer Coefficients . . . 39

1.2 Calciner Heat Exchanger Bundle. . . . . . . 50

13 Product Data, Run 1.............. 53

14 Calciner Bed Data, Run 1. . . . . . . . . 57

15 General Data, Run I............ 61

16 Product Data, Run 2............. 66

17 General Data, Run 2... . . . . . . . . 67

18 Product Data, Run 3.............. 69

19 General Data, Run 3 ............. 70

20 Product Data, Run 4 . . . . . . . . . 72

21 Calciner Bed Data, Run 4. . . . . . . . . . 74

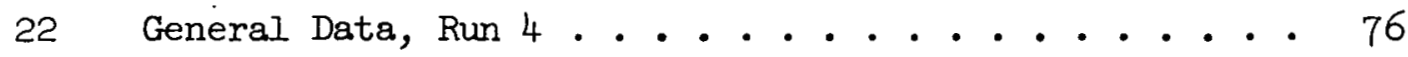

23 Product Data, Rur 6............... 81

24 Calciner Bed Data, Run 6............. 83

25 General Data, Run 6............. 85

26 Product Data, Run 8 . . . . . . . . . 89

27 Calciner Bed Data, Run 8. . . . . . . . . . 91 
28 General Data, Run $8 \ldots . \ldots 93$

29 Product Data, Run 9................. 96

30 Calciner Bed Data, Run 9............ 99

31 General Data, Run 9............ 102

32 Product Data, Run 10............ 106

33 Additional Product Data, Run 10 ......... 110

34 Calciner Bed Data, Run 10............ 114

35 General Data, Run 10................... 118 


\section{THIS PAGE}

\section{WAS INTENTIONALLY \\ LEFT BLANK}




\title{
DEVELOPMENT OF A FLUIDIZED BED CALCINATION PROCESS FOR. ALUMINUM NITRATE WASTES IN A TWO-FOOT-SQUARE PILOT PLANT CALCINER
}

\section{PART I. EQUIPMENT DEVELOPMENT AND INITIAL PROCESS STUDIES}

\author{
B. P. Brown \\ E. S. Grimett \\ J. A. Buckham
}

\section{SUMMARY}

Equipment development and process data obtained during the first ten extended runs made in a two-foot-square calciner are described. This calciner was designed to further the development of a fluidized bed calcination process for converting highly radioactive aqueous wastes into granular solids; specific studies were directed toward development of a process for calcining wastes from processing aluminum-uranium alloy fuels. Previous pilot plant work for this process had been conducted in a six-inch-diameter calciner, $(7)$ but that unit was not satisfactory for obtaining the data required to design a 48-inch-diameter Demonstrational Waste Calcining Facility (DWCF).(9) The two-foot-square calciner was designed, built, and tested so that process scale-up factors could be obtained and a liquid metal ( $\mathrm{NaK}$ ) heat transfer system could be tested. During the period covered by this report, equipment development progressed to the point where a voluntarily terminated continuous run of 43 days was made.

The two-foot-square calciner exceeded somewhat its designed capacity of calcining, at a bed temperature of $400^{\circ} \mathrm{C}$, 100 liters per hour of acidic aluminum nitrate feed solution. Excellent performance was achieved with the NaK heat exchanger; over-all heat transfer coefficients of from 40 to $100 \mathrm{Btu} /(\mathrm{hr})\left(\mathrm{ft}^{2}\right)\left({ }^{\circ} \mathrm{F}\right)$ were obtained. A tube-side-fired, in-bed heat exchanger was tested as a promising alternate method of supplying heat to the process; use of hot gases from a 50-psig oil-fired combustion chamber in the tubes of a heat exchanger resulted in over-all heat transfer coefficients of from 8 to $50 \mathrm{Btu} /(\mathrm{hr})\left(\mathrm{ft}^{2}\right)\left({ }^{\circ} \mathrm{F}\right)$.

Most of the calciner product properties were found to be associated with the relative amounts of amorphous and alpha alumina in the product; these properties varied widely throughout these runs, even though the operating variables were held constant, because conditions necessary for the conversion of amorphous alumina to the alpha phase were not known. Data indicate that a necessary but not sufficient condition for production of the alpha phase is the presence of sodium ion in the feed solution. A product which contains a high percentage of alpha alumina is harder to crush, is more dense, has a lower nitrate content, and is more friable than a product which has a lower percentage of alpha alumina. Thus, when a high alpha alumina-content product is being made, calciner bed weights are higher, particle sizes are smaller, and the amounts of 
small particles being elutriated from the bed of the calciner are greater than when a product containing little or no alpha alumina is being made.

Control of the particle size distribution in the product has been effected by altering the atomizing feed nozzle air-to-liquid volume ratio. However, for any given value of this ratio, a product containing a high percentage of alpha alumina consists of smaller particles than a product which contains a low percentage of alpha alumina.

Operability of the fluidized bed calcination process has been demonstrated in these studies over wide ranges of operating conditions. Additional studies are necessary to determine quantitative relationships between the many independent process variables and the product properties and other dependent variables. 


\section{INTRODUC'IION}

Extensive efforts on an international scale are being directed toward the ultimate disposal of radioactive waste solutions produced in process.ing spent reactor fuel elements to recover unused fuel: These efforts have been discussed extensively at AEC Working Meetings on the Fixation of Radioactivity in Solld Media, $(1,2)$ and at an International Conference on the Peaceful Uses of Atomic Energy. (3) There is general agreement among workers in this field that -- as a first step, at least -high-level liquid radioactive wastes should be converted to a solid state.

\section{A. The Fluidized Bed Calcination Process}

One of the most promising methods of converting aluminum nitrate and other reactor fuel wastes into a solid form is the fluidized bed calcination process. This process was originally conceived by the Argonne National Laboratory (ANL) Chemical Engineering Division. (4) For several years, the ICPP Technical Branch has been actively engaged in developing this process on a pilot plant scale. (5)

The fluidized bed calcination process, as currently conceived, involves spraying an aqueous solution of metal salts through pneumatic atomizing spray nozzles into a heated, gas-fluidized bed of granular solids where the salts are largely converted to the oxides. The freeflowing granular solids produced continuously in the bed leave the reaction vessel through an overflow pipe, and water vapor and volatile decomposition products leave with the fluidizing gas. Practical methods for furnishing heat to the fluidized bed include heating the vessel walls (for emall vessels) or placing heat exchangers in the fluidized bed (for larger vessels). The fluidizing medium can be any suitable gas (air, superheated steam, reducing or oxidizing gas), the selection depending upon the chemistry and economics of the particular process.

Fluidized bed calcination, as applied in these studies to aqueous wastes from processing aluminum alloy fuels, converts the acidic aluminum nitrate solutions into free-flowing granular aluminum oxide, with a resultant volume reduction in the range of six-to 20-fold. Nearly all of the feed spray droplets are deposited and dried in layers on the bed particles, although a small percentage of the droplets may be spray-dried.

Heat was supplied to the calciner in these studies by circulating $\mathrm{NaK}$ through a heat exchanger placed directly in the calciner bed. The $\mathrm{NaK}$ is heated by an oil-fired furnace whose firing rate is automatically controlled by the temperature in the calciner bed.

Fluidizing gas is introduced at the bottom of the calciner vessel and is evenly distributed to the alumina bed through an air-distributor bed-support plate. Alumina fines generated by attrition of the bed and by the feed spray nozzles are entrained by the fluidizing gas and must be separated before the air and waste gases are discharged to the atmosphere. The off-gas leaving the pilot plant calciner vessel is cleaned successively by a primary cyclone, a venturi scrubber with its associated cyclone, and a condenser. The fines removed by the primary cyclone are 
returmed to the bed, along with part of the off-gas, by means of an airjet pump utilizing part of the fluidizing air for the jet motive force. The fluidizing air is preheated so that the water vapor in the dry fines return gas does not condense. The cleaned off-gas from the pilot plant is finally discharged through a stack to the atmosphere. Figure 1 shows a schematic diagram of pilot plant equipment used to study this process.

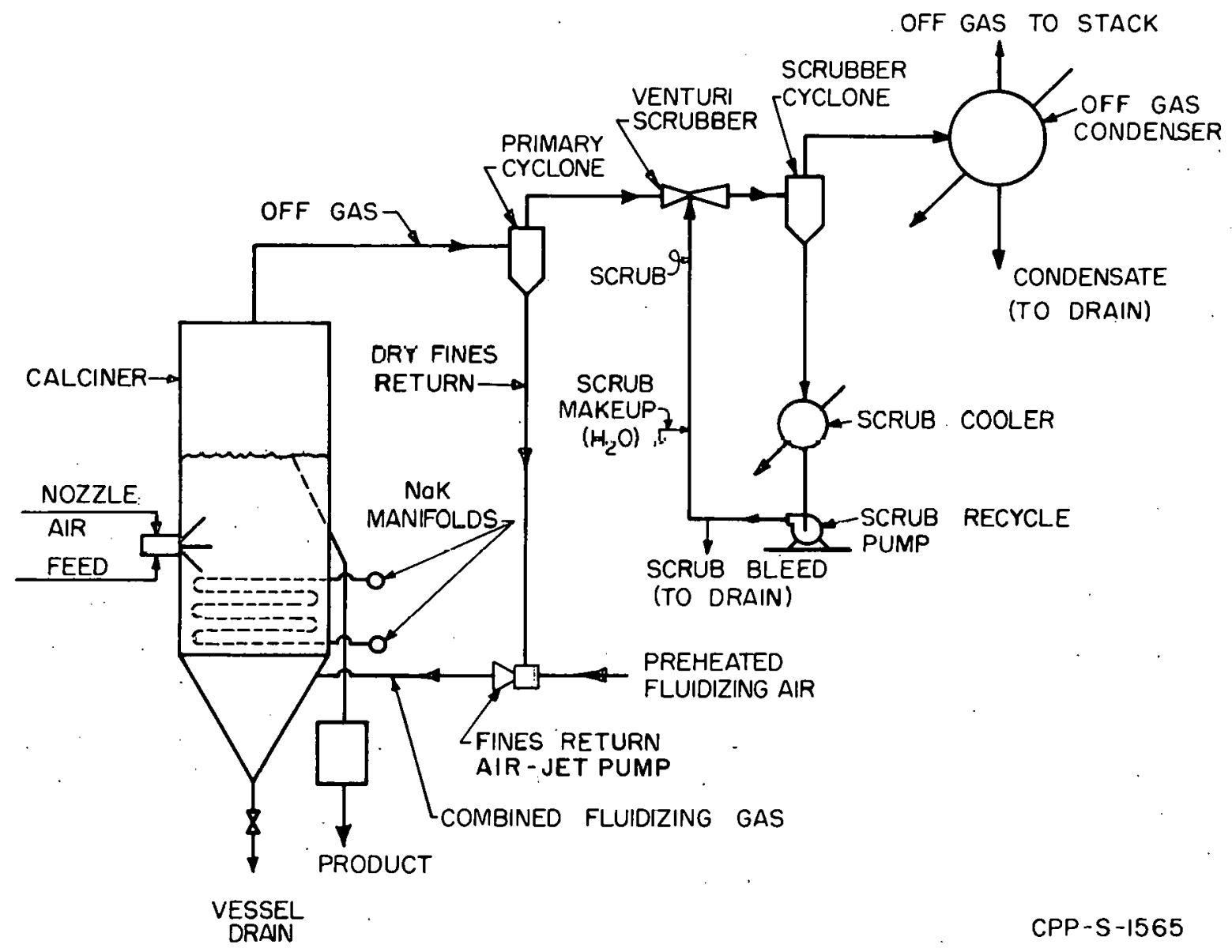

Fig. 1. Schematic Diagram of Two-Foot-Square Pilot Plant Fluidized Bed Calciner System

Increased radiological safety and a reduction in storage costs are expected to be among the results of this conversion of liquid to solid. Furthermore, corrosion problems associated with the liquid waste storage will almost surely be reduced significantly, and the solids would be essentially immobile should the container rupture during storage. Remote handling (necessary when high-level radioactivity is involved) makes extremely desirable the simplicity of operation and continuous processing offered by the fluidized bed calcination technique.

\section{B. Previous Fluidized Bed Calcination Studies}

ANL first used the fluidized bed calcination technique for the continuous fonversion of uranyl nitrate solutions to solid uranium trioxide. (4) This led to a study of the application of this technique to producing granular solids from aqueous radioactive wastes. The initial 
work was applied to the fluidized bed calcination of the acidic aluminum nitrate solution resulting from the recovery of fissionable material from a highly enriched uranium fuel of the MTR type.(5) Later studies included runs made with synthetic solutions spiked with up to 12 per cent of as-produced ICPP aqueous radioactive waste that was three to five years old. (8) All of these tests at ANL were conducted in a six-inchdiameter calciner.

Research and development work to determine the feasibility of fluidized bed calcination as a possible step toward the ultimate disposal of radioactive wastes was initiated at ICPP in May, 1955, using a six-inchdiameter ffuidized bed pilot plant calciner. (7) The most important information gained from studies in the six-inch calciner is summarized below:

1. A fluidized bed calciner for converting aqueous aluminum nitrate solutions to granular aluminum oxide was developed, and operability was demonstrated at temperatures from 185 to $550^{\circ} \mathrm{C}$ and at superficial fluidizing velocities from 0.6 to 4.5 feet per second.

2. The nozzle air-to-liquid volume ratio (NAR) was found to be a major operating variable which greatly influenced the product particle size.

3. In a run at $400^{\circ} \mathrm{C}$ with ruthenium-spiked feed, 67 per cent of the ruthenium introduced in the feed remained with the solid product, 28 per cent accumulated in the liquid stream from the condenser, and 5 per cent was not accounted for. This high a ruthenium retention in the product was obtained only by returning both dry and wet fines to the calciner.

4. Zirconium and stainless steel wastes were also successfully calcined to granular solid material in short exploratory mus.

C. Need for Additional Studies

Even though the results of the six-inch calciner studies were very encouraging, it became apparent in early 1956 that studies would have to be extended to a larger calciner and to development of a better heating system. The electrical heating elements used in the six-inch calciner were a constant source of trouble; momentary dead spots near heater. elements caused localized hot spots which usually burned out the heater elements. It was obvious that it would be extremely risky to operate a calciner in a remote cell, using such an unreliable heating system.

Preliminary planning was underway at that time for a Demonstrational Waste Calcining Facility (DWCF) $(9)$ which was to calcine a feed stream whose rate (60 gph) would be an increase of some 25 -fold over the highest feed rate used in the six-inch calciner. Scale-up problems of this magnitude were completely undefined, and design data that could be used for such a large unit were, for the most part, unavailable.

Several heating systems for a larger pilot plant calciner were considered, including high-temperature fluidizing gas, high-temperature 
liquid metal, fused salts, and Dowtherm: The final choice was a liquid metal heat transfer system using a 22 per cent sodium-78 per cent potassium alloy $(\mathrm{NaK})$ as the heat transfer medium. This choice was based on the following considerations:

1. High-temperature operation reduces the amount of heat transfer surface required for a given heat load and bed operating temperature. (For the NaK system, temperatures as high as $1400^{\circ} \mathrm{F}$ can be employed.)

2. For a given calciner feed rate, smaller heat transfer surfaces allow a smaller fluidized bed, and hence a smaller calciner vessel.

3. For a given calciner feed rate and fluidizing velocity, a vessel with a smaller diameter requires less fluidizing gas, and hence less off-gas must be treated in the off-gas cleanup system.

4. A properly designed liquid metal heat transfer system is reliable, and temperatures can be controlled easily.

These considerations led to the design and instillation of a twofoot-square pilot plant calciner having a feed capacity of 100 liters per hour of aluminum nitrate-nitric acid solution. The unit was heated w1th an oil-fired NaK heat transfer system. A fluidizing vesse.1, with a square cross section was chosen because it simplified considerably the design of the calciner heat exchanger and permitted construction of the vessel in local shops with available material. Except for unimportant cormer effects, it was assumed that fluidization would be as good in a square vessel as in a round vessel, an assumption substantiated by tests in a one-foot-square plastic model. Major purposes of this unit were: (1) to develop further the calcination process, (2) to provide engineering design data for the DWCF, (3) to test and operate the NaK heat transfer: system, and (4) to help train operators for the DWCF.

'I'he object of' this report is to present a summary of the equipment development effort and of initial process results obtained during the first ten extended calciner runs which culminated in a continuous, trouble-free run of 43 days. The calciner system is described, as are some of 'the problems encountered and solved in arriving at the final' design. Detailed operating data obtained during this period are presented in graphical form for each of the ten extended runs made. The problems associated with control of the product properties are discussed, and areas requiring additional development efforts are indicated. 


\section{EQUIPMEINT}

Equipment designed and developed during these studies is described in this section. A significant portion of the effort represented by these studies was expended in development of equipment, as opposed to development of the process; therefore, the courses of significant development efforts are summarized along with description of the equipment.

\section{A. Calciner Vessel}

The calciner is a vertical vessel two feet square by six feet high, and is constructed of 1/4-inch-thick Carpenter-20 stainless steel. The one-foot-high $\mathrm{NaK}$ heat exchanger is located in the lower portion of the vessel. Four pneumatic spray nozzles are mounted flush with the calciner inside wall, with their center lines six inches above the center line of the top tubes of the NaK heat,exchanger. A solids overflow pipe is located $37 \frac{1}{2}$ inches above the bed support plate, and allows the product to flow to a collection vessel. The bed support plate, containing many modified bubble-cap air distributors, is held between the two halves of the bottom calciner flange. A four-inch viewing port is located $2 \frac{1}{2}$ feet above the support plate. Figure 2 shows a schematic drawing of the assembled calciner vessel.

\section{Air Distributor Plate}

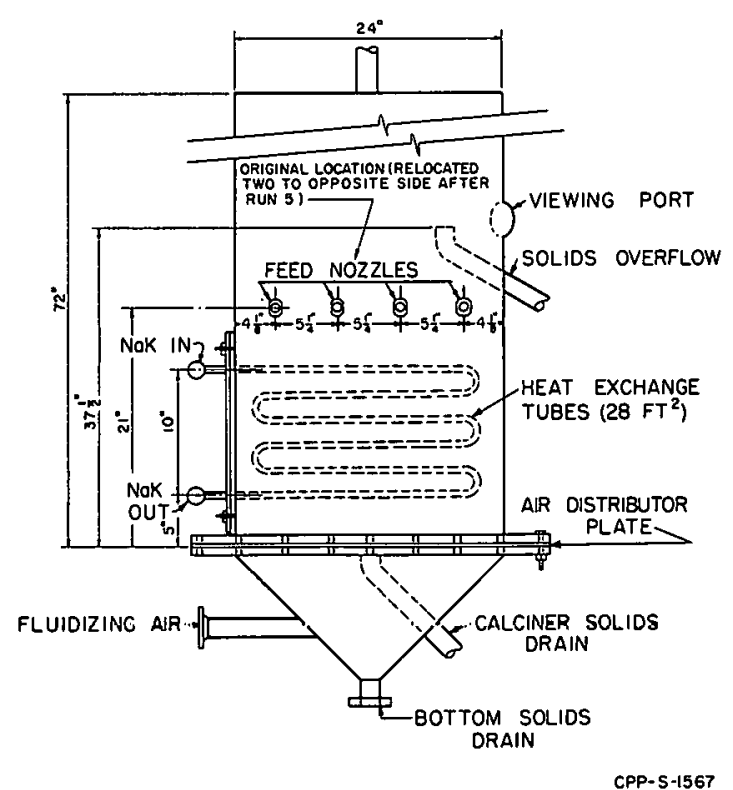

Fig. 2 Calciner Vessel Details
Dependable operation of a fluidized bed calciner requires that the bed be thoroughly fluidized, and that dead spaces be absent, in order to promote high thermal heat transfer rates and minimize the possibility of bed caking. To a large extent, this must be accomplished by proper introduction of the fluidizing medium into the bed, and hence by proper design of the fluidizing gas distributor or bed support plate. Fluidizing gas can be distributed adequately by a number of different designs, but with any design, satisfactory uniform fluidization cannot be achieved unless the pressure drop across the bed support plate is at least 40 per cent of the pressure drop across the bed.(10) When this provision is followed, rolling of the bed will not start preferential flow of gas through a portion of the bed.

The air distributor plate adopted after initial testing of several designs is shown in Figure 3. This 

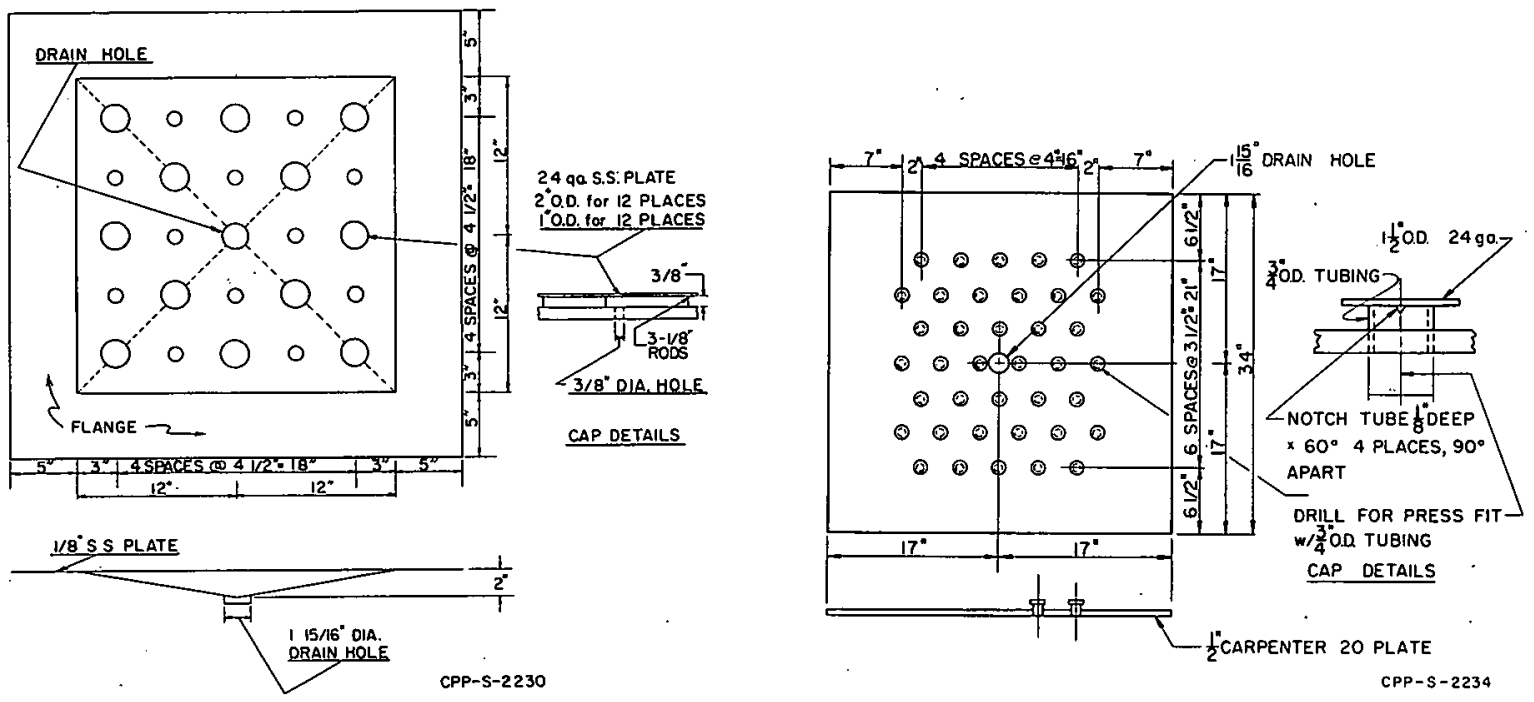

Fig. 3 Air Distributor Plate Used Subsequent to Run 6

Fig. 4 Initial Air Distributor Plate

plate, with its 23 capped openings, has given satisfactory service, and was used on Run 6 and subsequent runs. From 38 to 53 per cent of the pressure drop across the fluidized bed is generated across this plate when using superficial fluidizing velocities from 0.8 to 1.0 foot per second.

Other bed support. plates that were tested are listed below:

a. A flat bed support plate containing 38 air distributor caps positioned on a four-inch triangular pitch: Details of this plate are shown in Figure 4. This was the initial air distributor plate used in the calciner, and as far as could be determined, its operation was as good as that for the plate shown in Figure 3 .

b. A plate similar to that shown in Figure 3, except that it did not have air distributor caps and was perforated with 3/16-inch-diameter holes centered on a 1 13/16-inch triangular pitch: Evaluation of this plate was inconclusive, because during the test run the plate warped away from the center drain pipe and allowed part of the fluidizing gas to enter the bed through this rather large opening. During the initial part of the run, bed fluidization seemed to be good; later in the run, bed fluidization was poor. No further tests were made using this plate, but there are no known reasons why it should not give satisfactory service if properly installed.

c. A plate similar to that shown in Figure 3, except that it had twelve air distributor caps, placed over 3/4-inch-diameter holes spaced on a nine-inch-square pitch, instead of 23 capped openings. The pressure drop across this plate was only 9 to 13 per cent of that across the bed, and its use resulted in poor bed fluidization which in turn frequently 
caused the bed to cake. Operation of the calciner, using this plate, was extremely unsatisfactory.

\section{Product Removal System}

Product overflows continuously from the calciner vessel through a purged $l \frac{1}{2}$-inch solids-overflow line having a horizontal opening. Once the bed level stabilizes, the production rate is equal to the equivalent solids feed rate, less any sollds loss to the off-gas stream. The product is collected in a catch vessel which is emptied intermittently by means of Teflon-lined plug valves located in the inlet and outlet lines.

The opening to the solids-overflow line was initially $29 \frac{1}{2}$ inches above the air distributor plate, or $8 \frac{1}{2}$ inches above the feed nozzle level. At the conditions used, the bed level stabilized in early runs at a point which did not sufficiently cover the feed spray nozzles located at the $2 l$-inch level; operating under these conditions caused much of the feed to become spray-dried, and consequently produced a high solids loading in the off-gas. This problem was eliminated by adding an eight-inch extension to the solids-overflow pipe, making the opening $16 \frac{1}{2}$ inches above the feed nozzle level.

\section{Feed Nozzle Location}

Feed is introduced into the calciner through four feed nozzles located 21 inches above the air distributor plate. Two of the nozzles are located on one side of the calciner vessel, and two on the opposite side; the exact location of each nozzle is shown in Figure 2. Initially, all four nozzles were located on the same side of the vessel, but after Run 5 alternate nozzles were relocated on the opposite side so that the feed would be introduced more evenly throughout the calciner bed.

\section{Pressure Probes}

In-bed pressure probes are used to measure the pressure at points about $1 / 4$ inch and $12 \frac{1}{4}$ inches above the bed support plate. Both probes are pointed downward at $a 4^{\circ}$ angle. The lower probe extends into the bed to a distance of $5 \frac{1}{2}$ inches from the wall and is cut off horizontally; the upper probe is cut off flush with the wall. Additional pressure taps are installed below the bed support plate and above the bed.

5. Gasket Materials

Gaskets are used to connect the off-gas line, the drain lines, the product catch vessel, and the fluidizing gas line to the calciner vessel nozzles. The top, bottom, and heating coil tube sheet are all bolted to the calciner vessel through flanged, gasketed connections. Originally, all of the gasket material was made from an asbestos base, for high-temperature service. This was not a satisfactory gasket material for the bottom flange or for the heat exchanger tube sheet.

A satisfactory gasket material for the bottom flange was $1 / 8$-inch lead sheet. A good seal could be made using lead, even after the calciner 
bottom had been removed several times. Since the calcining temperature was generally higher than the melting point of lead, the gasket was kept cool by not insulating the flange and by passing cold air over hot areas near the NaK outlet header.

Temperatures around the heat exchanger tube sheet were so high that lead could not possibly be used as a gasket material. At this location, an aluminum "O"-ring type of gasket was used successfully. The seal was effected by two sets of two 1/8-inch-diameter aluminum rods spaced $3 / 4$ inch apart around each face of a 1/4-inch-thick aluminum gasket.

\section{B. Off-Gas Cleanup System}

Since the pilot plant calciner was designed to operate over wide ranges of off-gas rates, no single off-gas cleaning system could be installed to give maximum efficiency for all operating conditions. The primary cyclone and scrubber were designed on the basis of maximum of't-gas production, whereas the condenser was designed on the basis of maximum feed input. The units in this system were therefore not suited to obtaining design data on gas-cleaning efficiency. Such data were obtained in separate studies, and are reported separately.(11)

\section{Primary Cyclone}

The primary cyclone removes the major portion of the entrained solids from the calciner off-gas stream. The off-gas enters and leaves the cyclone through four-inch flanged connectors; the body of the cyclone is seven jinches in diameter. The cyclone design is that suggested by Lapple. $(6)$

\section{Fines Return Air-Jet Pump}

Collected fines are removed from the bottom of the primary cyclone and are combined with the fluidizing gas by means of an air-jet pump actuated with part of the fluidizing gas. Use of an air-jet pump for this service was initiated during studies with the six-inch calciner $(7)$ after serious difficulties were encountered with the use of a dipleg seal on that unit. The use of the air-jet pump circumvents the need for a mechanical contrivance, improves cyclone efficiency by removing a silhstantial portion of the gas from the cyclone bottom along with the solids, and reduces the amount of gas which must be treated downstream of the primary cyclone. However, additional development of this air-jet pump is required before one could be installed on a radioactive unit.

Serious erosion of the stainless steel mixing section of the experimental air-jet pumps was encountered on early runs; this was circumvented by use of liners made of tungsten carbide and of boron carbide.

Early operation of the air-jet pump with high-temperature $\left(1400^{\circ} \mathrm{F}\right)$ combustion gases as the motive force was unsatisfactory because frequent plugging from soot was encountered. Later operation using heated $\left(350^{\circ} \mathrm{F}\right)$ air was also unsatisfactory because at the maximum available pressure of 25 psig the air-jet pump does not develop sufficient head for this service. However, reliable trouble-free operation is indicated if 
a source of clean, high-pressure (60 psig) air is available; further development studies along this line are planned.

The measurement of the flow of gases containing solids, as was required in this system, was difficult. A venturi flowmeter was installed in the line between the bottom of the cyclone and the inlet side of the air-jet pump. At times, acceptable flow rate determinations were obtained; at other times, the pressure taps became clogged and rendered the meter inoperative. Use of the air-jet pump performance curve to determine this flow may be the best solution to this problem.

3. Venturi Scrubber and Demister Cyclone

The venturi scrubber and demister cyclone remove from the off-gas a high percentage of the fines not removed by the primary cyclone. The venturl throat of the scrubber used in the pilot plant unit was made $13 / 4$ inches in diameter to accommodate the wide variation in off-gas rates without incurring excessive pressure drop. The demister cyclone used in conjunction with the venturi scrubber is six inches in diameter and of conventional design.

\section{Off-Gas Condenser}

Following the scrubber system, the off-gas passes through a condenser where water vapor is condensed and oxides of nitrogen are partially absorbed. The shell-and-tube condenser contains 45 square feet of condensing surface and is operated as a downdraft unit, with the off-gas on the tube side.

\section{Scrub System}

Because a pump which could circulate the highly abrasive scrub solution slurry was not avallable, water was used on a once-through basis as the scrub solution during these studies. The slurry collected from the bottom of the demister cyclone was cooled and sent directly to the drain.

\section{Heating Systems}

\section{NaK System}

The recirculating NaK heating system used for this calciner has given excellent performance; during the tests reported herein, the system was heated from room temperature to operating temperature 112 times. The system was operated during this period with the $\mathrm{NaK}$ calciner inlet temperature between $1000^{\circ}$ and $1400^{\circ} \mathrm{F}$ for 5050 hours, and below $1000^{\circ} \mathrm{F}$ for 800 hours. Two external NaK leaks constituted the only serious operating problems with the system during this period; both leaks occurred because of thermal stresses at improperly designed tule-header joints.

An oil-fired furnace is used to heat the circulating NaK. The hot NaK passes through a 28-square-foot U-bend exchanger placed directly in the fluidlzed bed of the calciner, and is then circulated back to the furnace by means of an electromagnetic pump. The heating system is designed to deliver 500,000 Btu per hour to the calciner at a 
NaK inlet temperature of $1400^{\circ} \mathrm{F}$ and an outlet temperature of $1300^{\circ} \mathrm{F}$. Figure 5 is a schematic flow diagram showing the NaK heating system components. Additional details of the system are given in Appendix A.

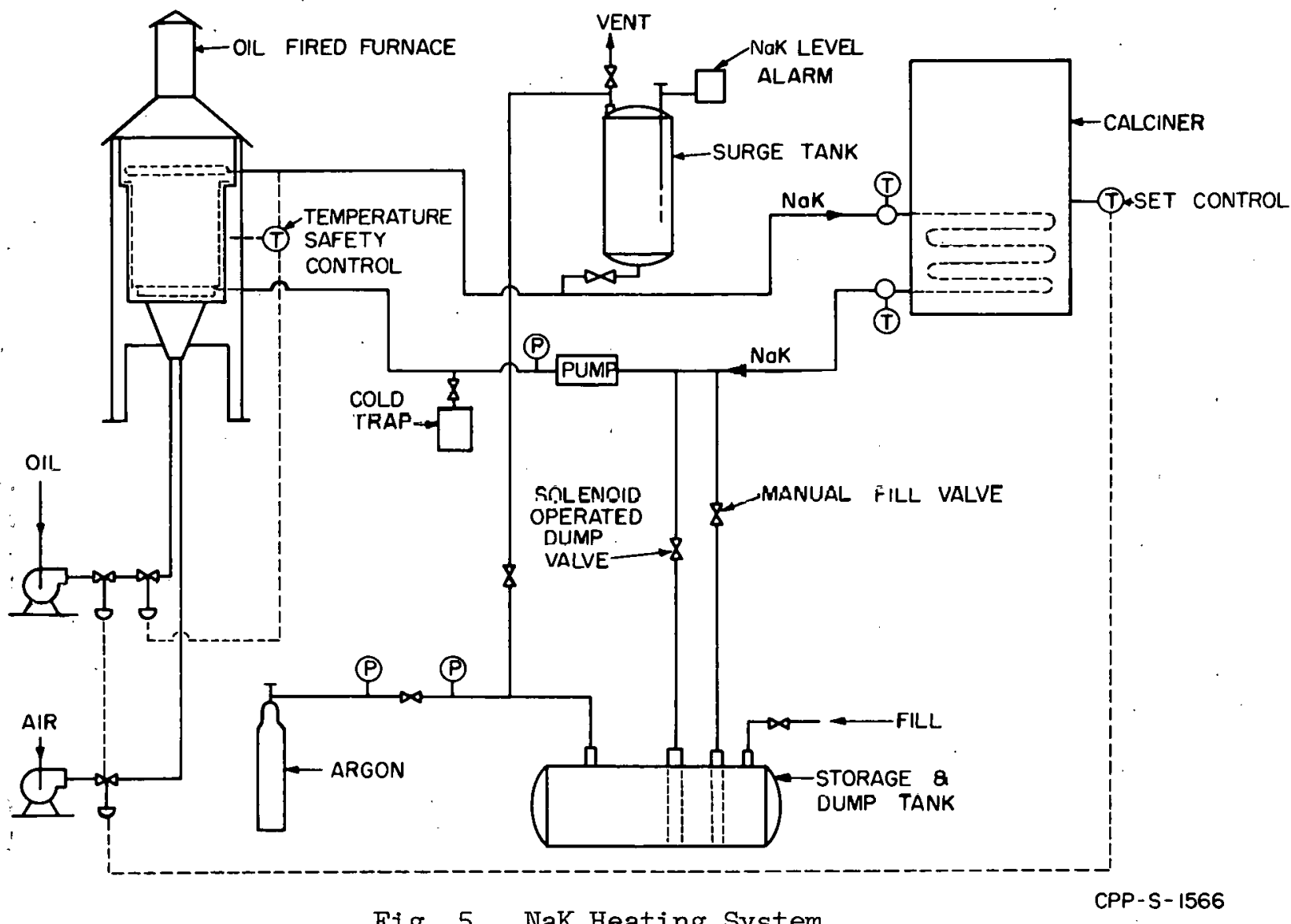

Fig. 5 NaK Heating System

2. Preliminary Systems

Delivery of the NaK heating system was delayed several months beyond completion of the calciner and other auxiliaries. During this interim period, an electrical heating system and a tube-s1de-fired heat exchanger were used to check out the calciner system.

Feed rates up to 30 liters per hour were possible when using a 24-unit, five-square-foot electrical heating system in conjunction with the use of hot combustion gased ns the fluidlzing medium.

Feed rates up to 30 liters per hour were possible with the special tube-side-fired heat exchanger pictured in Figure 6. Tubes for this unit were made from 3/4-inch Type 316 stainless steel tubing having a $0.06,5-1, n c h$ wall thickness; tntal hast transfer surface was ten square feet. Hot gases (up to $1200^{\circ} \mathrm{F}$ ) were supplied to the unit from a 50-psig oil-fired combustion chamber.

Over-all heat transfer coefficients obtained with the tube-side- 


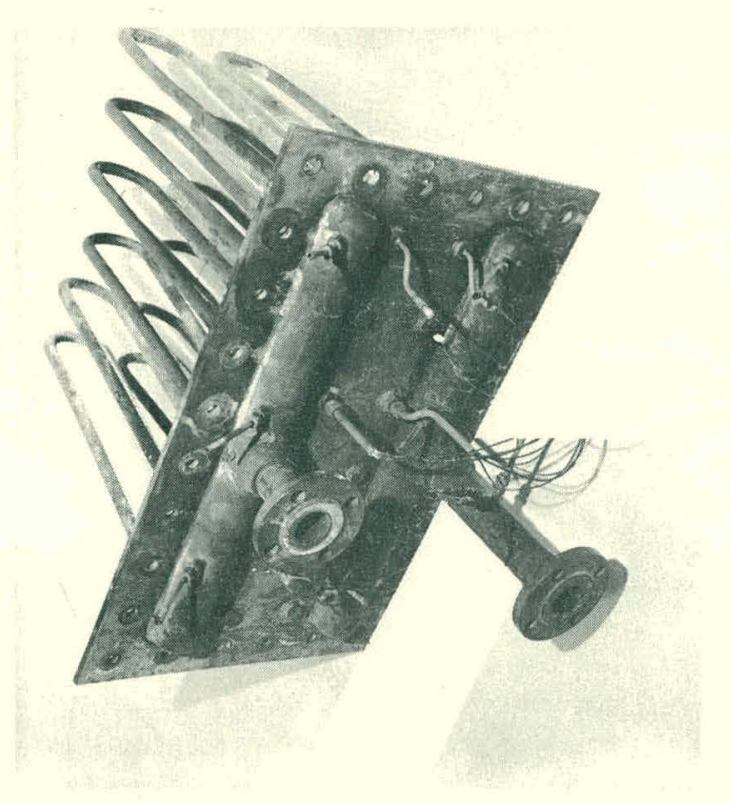

Fig. 6 Tube-Side-Fired Heat Exchanger

fired heat exchanger ranged from 8 to $50 \mathrm{Btu} /(\mathrm{hr})\left(\mathrm{ft}{ }^{2}\right)\left({ }^{\circ} \mathrm{F}\right)$, while overall coefficients ranging from 40 to $100 \mathrm{Btu} /(\mathrm{hr})\left(\mathrm{ft}{ }^{2}\right)\left({ }^{\circ} \mathrm{F}\right)$ were obtained with the NaK system. In view of the relatively high operating temperatures, relatively high heat transfer rates, and inherent low cost of the tube-side-fired heat exchanger, this type of heating system should be considered for future fluidized bed calciner installations.

\section{Fluidizing Gas Preheater}

The fluidizing gas for the fluidized bed calcination process should be heated above the dew point in the system to eliminate any possible condensation of water vapor in the plenum chamber or around the fluidizing gas distributor caps. In the present system, the fluidizing air

is preheated in a three-inch stainless steel pipe which carries metered air through the hot stack gases above the combustion chamber in the oilfired NaK heater. In earlier runs, the fluidizing medium was hot combustion gases or air heated by passing it through a pipe looped through the top of the calciner vessel.

\section{Feed System}

Feed is introduced into the calciner through four pneumatic atomizing spray nozzles. For the most part, Type 347 stainless steel construction is used throughout the feed system.

A canned-motor feed pump is used. Originally, an alumina-coated shaft and alumina bearings were to be installed in the pump so that slurry-bearing feed (from the scrub bleed stream) could be pumped through the system. Subsequent tests showed that these pump alterations did not solve the slurry-handling problem. Performance of the pump while handling solids-free feed has been excellent.

Feed is metered. to each of the four feed nozzles by an integral flow nozzle $\mathrm{d} / \mathrm{p}$ cell transmitter and pneumatic recorder-controller. An electromagnetic-type recorder-controller was tested in the feed system, also, and its operability was found to be excellent. Magnetic-torque and magnetic-induction flow recorder-controllers were also tested; the control effected by these instruments was completely unreliable. Manual feed rate control was also unsatisfactory.

The feed spray nozzles used are Spraying Systems Company, Type 1/4 J (catalog nozzle setup No. 4), which give a solid cone spray with a total spray angle of approximately $18^{\circ}$. The atomizing air is metered to each of the four nozzles through individual flowmeters. The relative 
volumetric rates of atomizing air and liquid feed are used to characterize the spray produced. High ratios of air rate-to-feed rate produce a spray containing very small droplets; low ratios produce a spray containing larger droplets.

\section{E. Process Control}

Process control points for the calciner and off-gas system are shown in Figure 7, and those for the NaK heating system were shown in Figure 5. These figures show the sampling locations, flows measured, temperatures measured, pressure taps, and pressure differences measured. Most of these data were recorded continuously during operation.

Product samples were routinely collected from the overflow stream and analyzed by methods discussed in Section IV. of this report. A bed sample was occasionally collected by means of the in-bed sampler shown in Figure 8. This sampler is located in the center of the calciner about two inches above the NaK heat exchanger. In operating this device, sufficient air is used to maintain a constant flow from the sample pickup out through the cyclone and back into the calciner vessel. Solids are removed from the air stream by the cyclone; when the cyclone is filled, the excess solids are carried back to the calciner vessel via the air stream. When a sample is required, the solids accumulated in the cyclone are dropped into the sample catch pot and discarded. A representative bed sample is then collected.

\section{F. Equipment Cleanout}

Many times during the operation of the two-foot-square calciner, conditions were such that portions of the bed became caked. Some of this caked material formed around the heat exchanger tubes to the extent of almost half the bed volume. Other material seemed to originate at the feed nozzles and grew to the size of basketballs. In nearly every case, the formation of caked material in the bed was made evident by erratic bed temperature and bed differential pressure readings. Determination of suitable cleanout methods is, of course, mandatory for operation with radioactive material.

Various methods of cleaning caked material from the interior of the calciner were tried. The most successful method, and one which is adaptable to remote operation, consists of boiling dilute ( $2.0 \mathrm{M}$ ) nitric acid in the calciner for a few hours until the caked material disintegrates. At this point, the solids slurry is flushed from the bottom of the calciner. During this procedure, sufficient fluidizing gas is admitted to keep the acid in the calciner above the bed support plate. If any caked. material still remains in the calciner vessel, the procedure is repeated. This method is also effective in cleaning the calciner vessel walls and off-gas lines. In hot operation, it would be advantageous to remove from the calciner as much as possible of the uncaked solids before the cleaning procedure is initiated, to minimize the amount of radioactive slurry which must be returned to the calciner feed system. 
(5) SAMPLE T TEMPERATURES RECORDED

(F) FLOW (P) PRESSURE TAPS

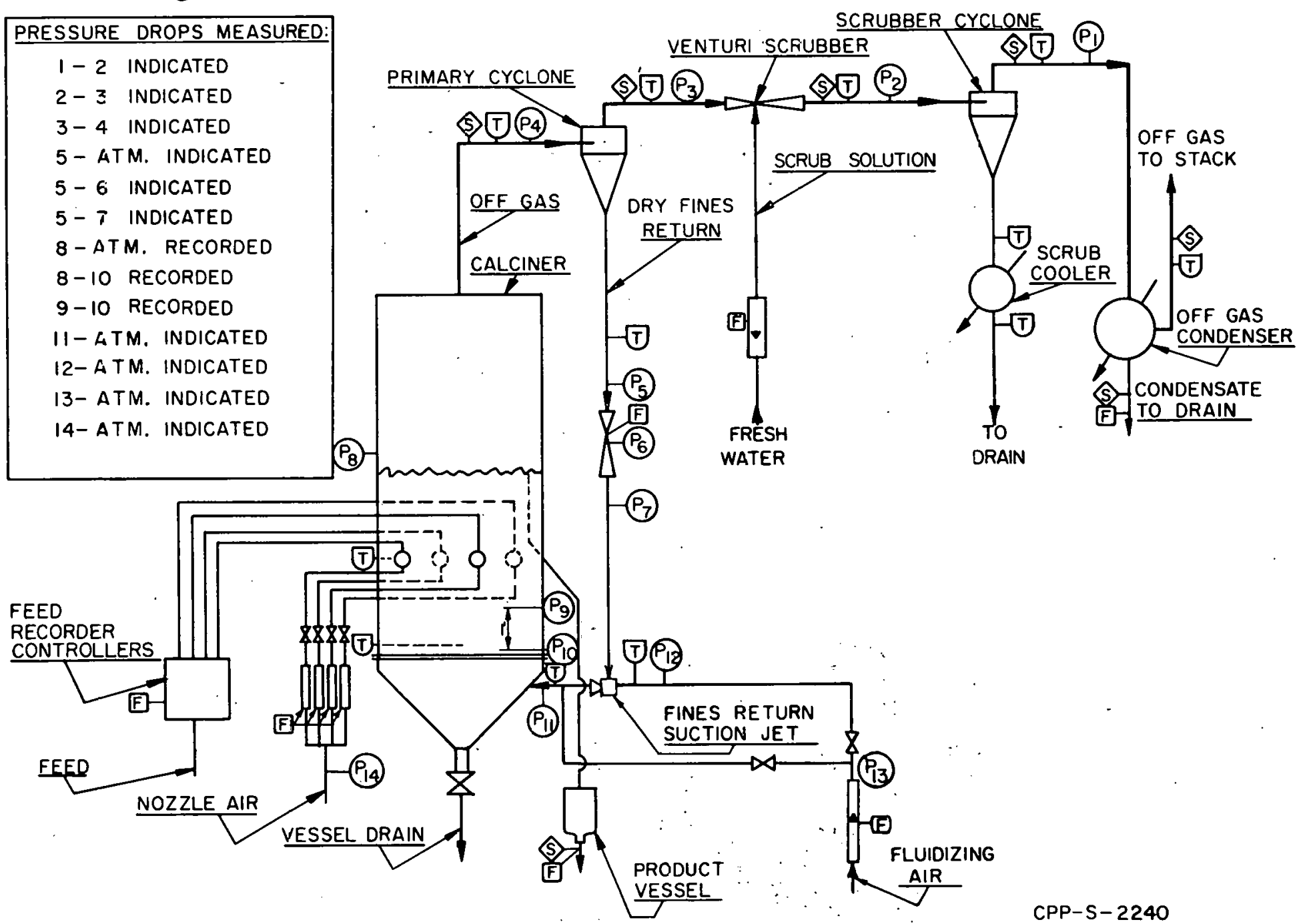

Fig. 7 Calciner Process Control Points 


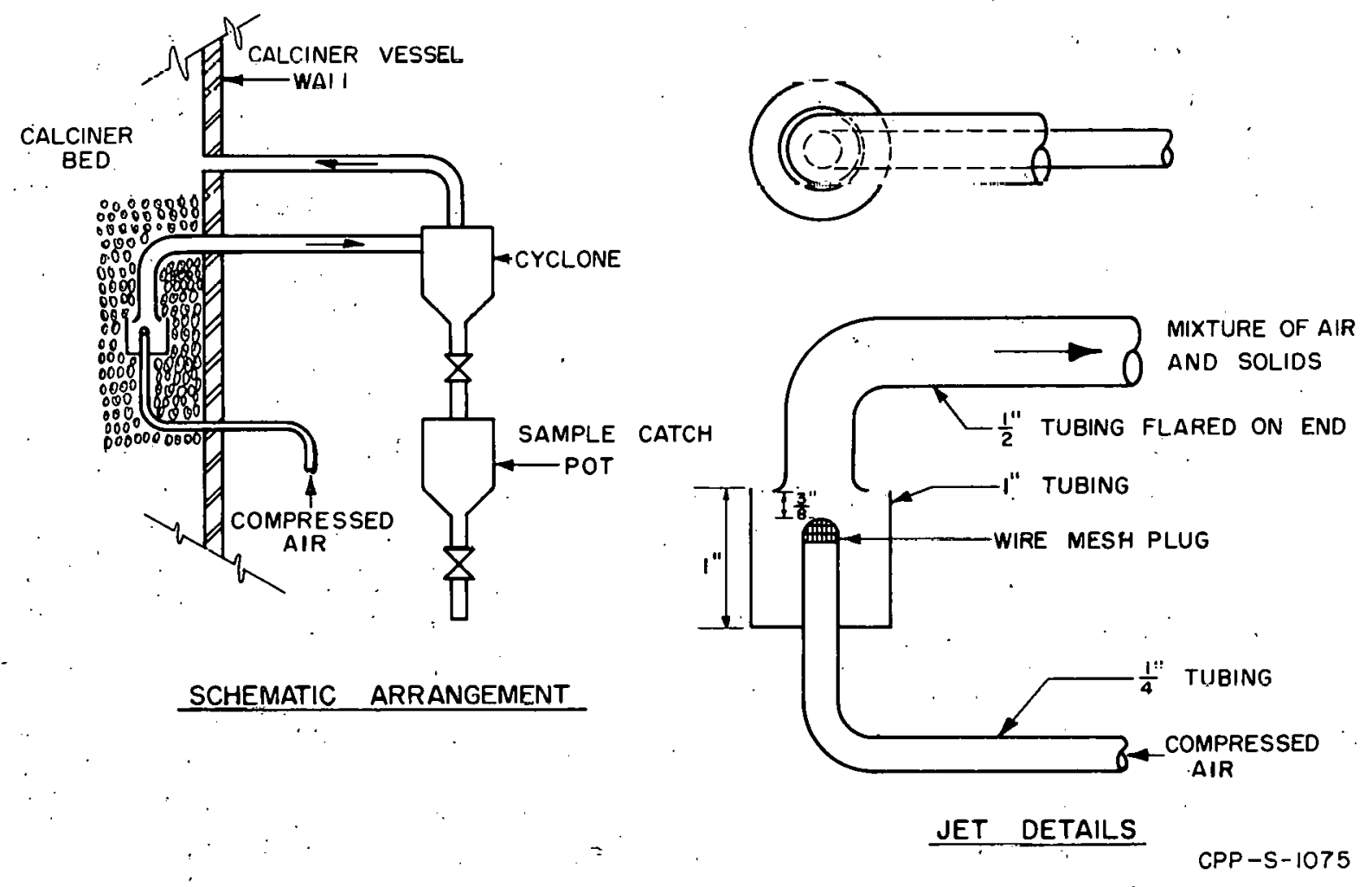

F1g. 8 In-Bed Product Sampler 


\section{INITIAL PROCESS STUDIES}

Simultaneously with the equipment development efforts made during the first ten calciner runs, considerable data of process significance were obtained. The fluidized bed calcination process mechanism is exceedingly complex, and is far from defined in detail today. In view of the process complexity, studies to generate process information generally were made on an empirical rather than on a mechanistic basis.

The independent operating variables are:

Feed rate to calciner Nozzle air-to-liquid volume ratio Superficial fluidizing velocity Calciner bed temperature

Feed composition

Dry fines return from primary off-gas cyclone

The significant dependent variables are:

Product particle size distribution

Product bulk density

Product nitrate content

Product alpha alumina content

Calciner vessel pressure

Sollds loading in the off-gas

The calciner vessel pressure could be independently controlled, but in these studies it was allowed to reach a value which depended on the other factors; hence, it is included with the dependent variables.

Sufficient data were obtained during these first ten runs to permit estimation of the operable ranges of many of the independent variables and to determine the possible variation in many of the product properties. Process data procurement was subordinated to equipment development, however, and the necessary concurrent testing of equipment frequently made process data analysis difficult.

General process data developed during these studies are discussed in this section of the report; detailed data summaries for each run are presented graphically in Appendix B.

A. Observed Operating Variable Ranges

During the initial runs in the two-foot-square calciner, the operable ranges were unknown for many of the variables, such as the feed rate, the fluidizing velocity, the bed temperature, and the feed nozzle air rate. Imposing operating variable values into the system which were not in an operable range resulted in equipment malfunction and often in a caked bed. Sometimes the results of a poor choice took several days to manifest themselves. As operating experience was accumulated, involuntary equipment shutdowns became less frequent, and finally a continuous run of 43 days was achieved. 


\section{Feed Composition}

Unless otherwise specifled, the feed composition used during the ten runs reported was:

$\begin{array}{ll}\text { Aluminum nitrate, } \frac{M}{\bar{M}} & 1.95 \\ \text { Nitric acid, } & 1.25 \\ \text { Sodium nitrate, } \bar{M} & 0.089 \\ \text { Mercuric nitrate, } \bar{M} & 0.006\end{array}$

While this composition does not correspond precisely to that of the liquid in any of the ICPP waste storage tanks, it is similar to that of the liquid stored in all of them.

\section{Calciner Capacity}

'I'raneter of' heat into the fluidized bed is apparently the factor which limits the capacity of this unit. Assuming that the source of heat is not limited, that the bed is well fluidized so that it has the usual extremely high heat-carrying capability from one part of the bed to another, and that the heat transfer coefficient between the NaK coil and the bed is fixed at some value, the capacity of the calciner is determined by the feed composition, the bed temperature, and the mean NaK temperature in the heat transfer coil. For all ten mus reported, the bed calcination temperature was maintained at $500^{\circ} \mathrm{C}$; feed rates ranged from 40 to 100 liters per hour.

The calculated calciner feed capacity for various bed temperatures, various mean $\mathrm{NaK}$ calciner heat exchanger temperatures, and for a heat transfer coefficient of $50 \mathrm{Btu} /(\mathrm{hr})\left(\mathrm{t}^{2} \mathrm{t}^{2}\right)\left({ }^{\circ} \mathrm{F}\right)$ is plotted in Figure 9. The ranges of the variables shown were those usually employed in these studies. For these conditions, and without exceeding a mean NaK temperature in the calciner heat exchanger of $1350^{\circ} \mathrm{F}$ (the boiling point of $\mathrm{NaK}$ is $1444^{\circ} \mathrm{F}$ ), calciner feed rates up to 285 liters per hour are indicated for a bed temperature of $300^{\circ} \mathrm{C}$; this capacity drops to $205 \mathrm{l} / \mathrm{hr}$ at a $400^{\circ} \mathrm{C}$ bed temperature, to $125 \mathrm{I} / \mathrm{hr}$ at a. $500^{\circ} \mathrm{C}$ bed temperature, and to $50 \mathrm{l} / \mathrm{hr}$ at a $600^{\circ} \mathrm{C}$ bed temperature. A proportionally higher capacity would be attainable if operating conditions were such as to result in a higher over-all heat transfer coefficient. As discussed in a subsequent section, experimentally determined heat transfer coefficients have ranged from 40 to $100 \mathrm{Btu} /(\mathrm{hr})\left(\mathrm{ft}^{2}\right)\left({ }^{\circ} \mathrm{F}\right)$.

\section{Superficial Fluidizing Velocity}

The superficial fluidizing velocity is defined on the basis of the empty cross section of the calciner at the calciner bed temperature and vessel pressure, and includes the combined fluidizing gas (fresh air and dry fines return gas); it does not include the nozzle air, the water vapor, or the decomposition products of the feed, although some of these materials undoubtedly circulate below the feed nozzles and influence the effective velocities throughout the bed.

No doubt a minimum usable fluidizing velocity exists for each combination of feed rate and bed temperature, but these have not been 


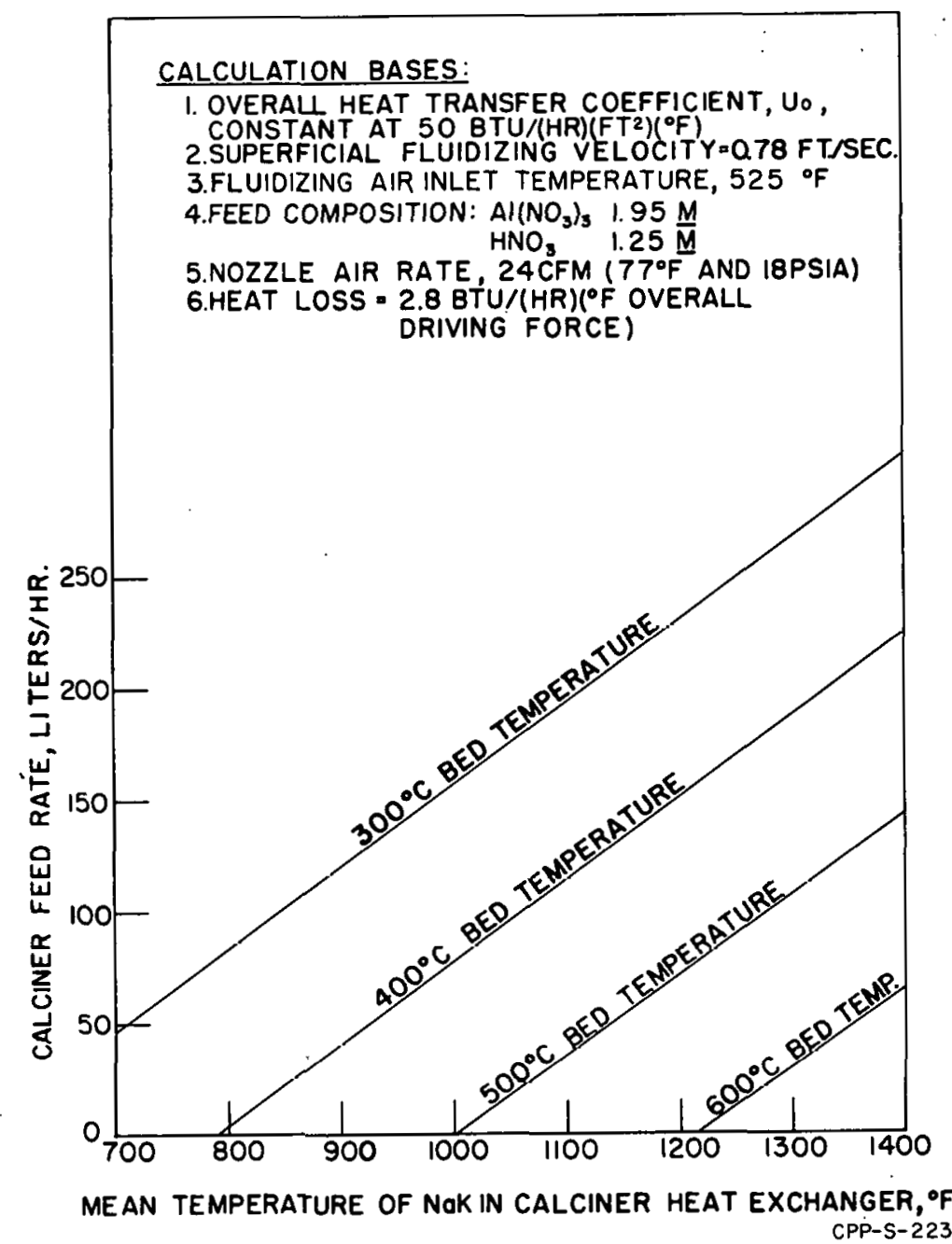

Fig. 9 Two-Foot-Square Calciner Capacity

determined precisely as yet, Other factors important in determining the minimum usable fluidizing velocity are the way the fluidizing medium is distributed to the bed, the particle density, and the size distribution of the material in the bed.

Superficial fluidizing velocities used during this test perlod ranged from 0.3 to 1.0 foot per second. When operating the calciner with a feed rate of $40 \mathrm{l} / \mathrm{hr}$ and a bed temperature of $500^{\circ} \mathrm{C}$, a superficial fluidizing velocity of $0.3 \mathrm{ft} / \mathrm{sec}$ was found to be too low. At this same feed rate and bed temperature, a superficial fluidizing velocity of 0.64 $\mathrm{ft} / \mathrm{sec}$ seemed to be in an operable range; however, there were some indications that this velocity might be borderline.

At feed rates of $80 \mathrm{l} / \mathrm{hr}$ and bed temperatures of $500^{\circ} \mathrm{C}$, superficial fluidizing velocities up to $1.0 \mathrm{ft} / \mathrm{sec}$ were successfully employed. A continuous run of 43 days was made at a superficial fluidizing velocity of $0.78 \mathrm{ft} / \mathrm{sec}$ with a feed rate of $80 \mathrm{l} / \mathrm{hr}$ and a bed temperature of $500^{\circ} \mathrm{C}$. 
4. Feed Nozzle Air

Both the air flow and the feed flow to each feed nozzle are metered independently. The feed nozzle air-to-liquid volume ratio (NAR) has been useful in characterizing, in a general way, the nature of the spray from the feed nozzles. For consistency in applying this ratio, the air volume is determined at the metered temperature and the calciner vessel pressure. A high NAR value produces a spray having a large number of very small droplets; a low NAR produces a spray having fewer and larger droplets. In general, if the calciner is operated with a high NAR, the particle sizes in the bed become small; if the calciner is operated with a Low NAR, the particle sizes in the bed become large. Use of too low a value of NAR promotes formation of caked calcine around the feed nozzles and heat transfer tubes. Use of too high a value of NAR results in excessive amounts of fines being entrained in the off-gas. NAR values have ranged from 195 to 486 in these initial studies.

It is a fundamental requirement of steady-state operation that new particles be introduced into and captured in the calciner her at the same rate as product particles leave the calciner bed. Small "spray-dried" aroplets from the feed nozzle can produre some of these now particlea; attrition of the particles in the bed, particularly by the high-velocity nozzle stream, accounts for the remainder. The relative role each wechanism plays in producing new particles is not presently known, nor is the relative size distribution of the newly generated particles. It is also clear that new particles which are smaller than a given size are almost quantitatively elutriated from the bed and leave with the off-gas and are therefore not effective as "seed" particles.

A test was conducted to determine qualitatively the source of newly generated particles. The initial feed rate was 80 liters per hour, and a sufficient flow of nozzle air was maintained to give an $N A R$ of 282 . Scrub samples were taken 30 minutes after each of several different atomizing nozzle conditions was imposed on the calciner. The results of these tests are summarized in Table 1 . The average amount of fines caught in the scrub stream when operating with water and with feed solution in the nozzle was used as the basis for reporting the fines production rate under other conditions. From these data, it is concluded that: (a) the greatest quantity of fines is generated when feed solution or water is fed through the nozzle; (b) the amount of atomizing air has a considerable effect on the production of fines; and (3) that in this experiment, approximately 20 per cent of the fines was produced by attrition caused by the fluidizing air alone.

\section{B. Produot Properties}

In this section, methods used for determination of product properties are described, and ranges over which these properties have been observed are discussed. Some of the properties were not determined routinely until during later runs when their significance was recognized. In such cases, available samples from previous runs were re-analyzed. 
Table 1

THE EFFECT OF THE FEED SPRAY NOZZIE OPERATING CONDITIONS ON THE PRODUCTION OF FINES IN THE TWO-FOOT-SQUARE CALCINER

No dry fines return

Alpha alumina content of bed: 77 per cent

Mass median particle diameter: $0.44 \mathrm{~mm}$

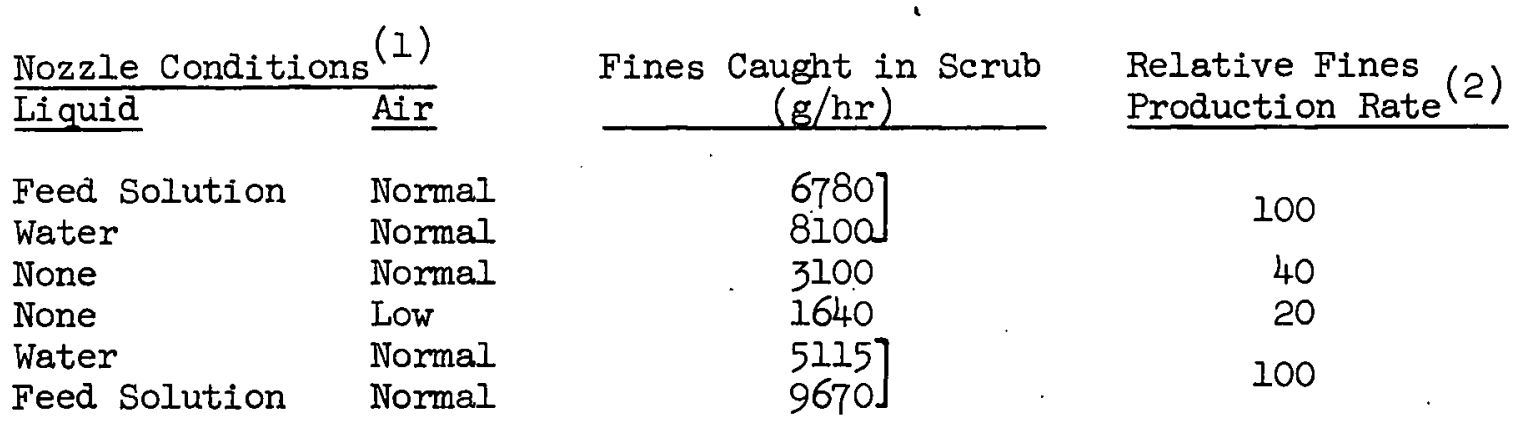

(1) The liquid rate for both water and feed solution was 80 liters per hour. Normal air was that amount of nozzle air required to give an NAR of 282. Low air was that amount just sufficient to keep the air orifice from clogging.

(2) Based on the average scrub fines rates for both water and feed solution.

I. Product Particle Size Distribution

The size distribution of the product particles is an extremely important product property. The rate of heat transfer from a heat source to a heat sink in a fluidized bed is strongly influenced by the particle size distribution of the bed. Also, factors affecting the transportation of granular solids from one location to another are influenced by the particle size distribution of the transported material. Therefore, determination of the product particle size distribution and of factors influencing this property was an important part of the experimental program.

The product size distribution is determined by making a screen analysis using Tyler screens and a Tyler "Rotap" Testing Sieve Shaker. The Tyler screen sizes generally used during these muns were 14, 20, 28, 35,65 , and 100 mesh, although other sizes were used wheri needed. A $250-m l$ homogenous sample of the product is weighed and then screened for 15 minutes in the "Rotap" Shaker. The weight percentage of the material retained on each screen is then determined.

The results are reported herein as cumulative weight percentage finer than the screen size shown. 
It is desirable to represent all the particle sizes by an average or median particle diameter. The mass median particle diameter $\left(\mathrm{d}_{50}\right)$ is used for this purpose in this report; it is defined as the particle diameter of a sample at which 50 per cent of the mass is associated with larger particles and 50 per cent with smaller ones. It can be determined graphically by plotting the cumulative screen analysis vs the particle diameter. The following empirical equation was developed for more rapid determination of $\mathrm{d}_{50}$ :

$$
\begin{aligned}
& \mathrm{d}_{50}=\mathrm{d}_{\mathrm{n}}-0.008(\mathrm{~mm}) \\
& \mathrm{d}_{\mathrm{n}}=\overline{\mathrm{n}}_{1} \mathrm{D}_{\mathrm{p}_{1}}+\overline{\mathrm{n}}_{2} \mathrm{D}_{\mathrm{p}_{2}}+\cdots=\sum \overline{\mathrm{n}} \mathrm{D}_{\mathrm{p}}
\end{aligned}
$$

where $\bar{n}=\begin{aligned} & \text { weight fraction retained between two } \\ & \text { consecutive screens }\end{aligned}$

$\mathrm{D}_{\mathrm{p}}=\begin{aligned} & \text { geometric mean opening of the two corresponding } \\ & \text { rnnserutive screen sizes } \cdot(\mathrm{mm})\end{aligned}$

A statistical analysis of 46 product samples indicated that 90 per cent of all graphical d50 values will be within $0.0076 \mathrm{~mm}$ of the value calculated from the preceding equation.

During the calciner runs summarized in this report, the $d_{50}$ value of the product, and hence of the bed, varied from a low of $0.33 \mathrm{~mm}$ to a high of $1.35 \mathrm{~mm}$. High NaK tube-to-bed heat transfer coefficients are associated with beds having a low value of $d_{50}$, while low heat transfer coefficients are associated with beds having high values of $d_{50}$. Beds with high $\alpha_{50}$ values are difficult to fluidize, whereas the elutriation of fines is high from beds with low $d_{50}$ values. A $d_{50}$ range which represents a practical compromise of the above factors is from 0.25 to $0.6 \mathrm{~mm}$. Within this particle size range, fluidization is good, over-all heat transfer coefficients from the $\mathrm{NaK}$ to the fluidized bed are at least $50 \mathrm{Btu} /(\mathrm{hr})\left(\mathrm{ft}^{2}\right)\left({ }^{\circ} \mathrm{F}\right)$, and the fines elutriation rate is within an acceptable range.

\section{Product Bulk Density}

The bulk density is the weight, in grams, of a cubic centimeter of poured, unpacked, solid product. This property is used to determine the reduction in volume of the original calciner feed and in determining the volume required for storing a given weight of calcined product. It is obvious that an optimum product should have a bulk density as high as possible.

Prior to Run 9, the procedure used for bulk density determination permitted handling techniques to influence the result, and caused a relatively wide data spread. The improved procedure used on Run 9 and on all succeeding runs consisted of pouring rapidly a 600 - to $800-\mathrm{ml}$ sample of product into a supported funnel whose discharge spout is two inches above a standard one-liter graduated cylinder cut off at the 500-ml mark. Care is taken to prevent packing by unnecessary movement of the cylinder. 
The excess solids on top of the cylinder are removed by drawing the blade of a spatula across the top of the cylinder, and the bulk density is determined by weighing the $500 \mathrm{ml}$ of unpacked solids.

For the feed composition used during these experiments, the product bulk density has varied from a low of $0.60 \mathrm{~g} / \mathrm{cc}$ to a high of $1.28 \mathrm{~g} / \mathrm{cc}$. The bulk density depends upon the absolute material density, the intra-particle porosity, and the inter-particle vold fraction of the particles. The first two of these factors are discussed in succeeding subsections. The inter-particle void fraction depends on the shape of the particle and the particle size distribution in the sample. During Runs 8,9 , and 10, the bulk density was determined on a gross product sample and on a sample of $-28,+35$ Tyler mesh material taken from the gross product sample. Since the bulk density of both samples varied with time in the same direction and over the same range of values, it is concluded that the changes in product bulk density noted during these runs were due to changes in the particle density of the product material, not to changes in the vold spaces between the particles. A constant inter-particle void fraction of 0.41 is indicated by particle apparent density measurements discussed in a later subsection.

\section{Absolute Material Density}

The absolute material density is the density of the basic material from which the particle is formed. It is measured on the assumption that a suitable liquid fills even the smallest of the voids within the particles in a sample contained in a pycnometer. In the analytical method for determining this property, a known weight (about 10 grams) of product sample is placed in a pycnometer of known volume. Carbon tetrachloride is added, the solids are de-gassed by vibration and vacuum techniques, and the pycnometer is again weighed. The absolute density of the sample material can then be calculated.

From the standpoint of the volume reduction of the waste during calcination, it is advantageous to have a product with as high an absolute material density as possible. Calciner product has been obtained with absolute material densities between 2.6 and $3.8 \mathrm{~g} / \mathrm{cc}$.

\section{Apparent Particle Density}

The apparent particle density is defined as the density, in $\mathrm{g} / \mathrm{cc}$, of the material which would be observed if the particles were covered with a weightless, dimensionless, impermeable membrane which would follow the surface contour, including the surface cracks and pores. The volume of the intra-particle pores is thus included in the volume used to compute this density value.

The development of an analytical method (13) for this measurement was completed in time for Run 10. In the method, mercury is used as the displacement liquid. The high interfacial tension between it and alumina minimizes its penetration into the intra-particle voids. The method involves (1) placing a weighed sample into a container of known volume, (2) evacuating the air with a vacuum pump, and (3) introducing mercury under continuously increasing pressure. The inflow of the mercury stops 
when the particles are "completely outlined". The difference in the volume of the empty container and the volume of the mercury at complete outlining is the apparent particle volume; dividing this into the sample weight gives the apparent particle density.

Product apparent particle densities have ranged from a low of 1.0 to a high of $1.8 \mathrm{~g} / \mathrm{cc}$. Values determined in these studies are plotted in Figure 10, which indicates a linear relationship between bulk density and apparent particle density.' Such a linear relationship can exist only if all samples had the same inter-particle void fraction. The constant inter-particle void fraction indicated by this correlation is 0.41 .

\section{Intra-Particle Porosity}

A product with the highest possible bulk density would incorporate a high absolute density with a low intra-particle porosity. The intra-particle porosity of the product is the volume traction of voids within a particle, and can be calculated by the following relationship:

$$
\text { Intra-particle porosity }=\frac{\rho_{\mathrm{a}}-\rho_{\mathrm{p}}}{\rho_{\mathrm{a}}}
$$

where

$\rho_{\mathrm{a}}=$ product absolute density

$\rho_{\mathrm{p}}=$ product apparent particle density

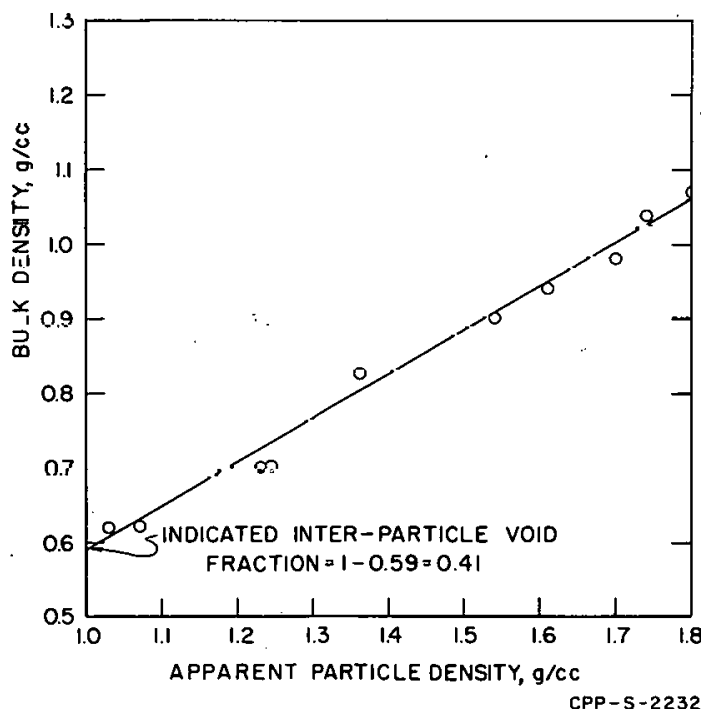

Fig. 10 Relationship Between Bulk and Apparent Particle Densities of Calcined Alumina
Calculated values of the product intra-particle porosity during Run 10 averaged 0.60 ; this characteristic could not be obtained in earlle! dus bechuse the apparcrit particle density determination had not yet been developed.

\section{Product Nitrate Content}

The amount of nitrate rcmaining in the calcined product is a measure of the completeness of the calcination reaction. Aluminum nitrate decomposes at $150^{\circ} \mathrm{C}$, sodium nitrate decomposes at $380^{n} \mathrm{c}$, und mirurli nitrate melts at $79^{\circ} \mathrm{C}$ and decomposes above this temperature.

Calciner product nitrate analyses indicate that some nitrate remains even though the retention times are long and bed temperatures are above the decomposition temperatures. Since the decomposition temperature 
of sodium nitrate is much higher than that for the other nitrates, it was thought at first that most or all of the nitrate remaining in the product was associated with the sodium. However, because the usual amount of nitrate was also found in product made with feed containing no sodium nitrate, considerable doubt must be cast on that hypothesis.

Calcination runs made in the six-inch calciner(5) showed that the calcination temperature had a marked effect on the nitrate content of the product; that is, low product nitrate contents were associated with high calcination temperatures. The effect of retention time in the calciner on the product nitrate content has not been clearly defined by any of the studies to date.

The product nitrate contents have varied from 0.22 to $0.95 \mathrm{milli}-$ mole of nitrate per gram of product. A Kjeldahl method is used for determining the nitrogen content of the product, which in turn is reported as nitrate.

\section{Product Hardness}

The product hardness is determined by crushing, individually, twenty particles from a closely sized product. The average force in grams required to crush each particle is calculated and reported. Ordinarily, particles passing through a 28-but retained on a 35-Tylermesh screen are used for this test. Reproducibility of the test results is poor, but the test does give some indication of the resistance to crushing of the product particles. Values of product hardness have been observed over a range of from less than 120 grams (detectability limit) to 460 grams.

\section{Structure of Calcined Alumina}

Although alumina can exist in a number of forms, only two have been found in the calcined product with any degree of regularity. The calcined product has been either amorphous alumina or a mixture of amorphous and alpha alumina. Alpha alumina content of the product is determined by $\mathrm{X}$-ray diffraction analysis, and is reported as the percentage of the total sample. Material not identifiable as crystalline by this technique is defined as amorphous. The observed alpha alumina content of the product has varied from zero to 85 per cent. When an alpha alumina value of zero is reported, no alpha alumina was found in the sample. However, if alpha alumina is detected in the sample but does not exceed 5 per cent, the results are reported as $<5$ per cent.

The significant direct effect of the structure of the calcined alumina on product properties and its indirect effect on many of the other dependent variables were detected during these studies; however, factors causing formation of a particular form were not icolated. Particles containing a relatively high percentage of alpha alumina are more easily attrited than those with a lower alpha alumina content. Consequently, high alpha alumina content beds contain smaller particles and generate more overhead fines than do low alpha content beds. High alpha alumina content beds are more dense and contain less nitrate than low alpha alumina content beds, both desirable features. 
A striking example of the effect of a change in bed alpha alumina content is shown in the data plots for Run 10 in Appendix B. During that run (on March 22, 1960), without changing any of the operating variables, the properties of the calcined material changed markedly over a 24-hour period. The bulk density increased, the product hardness increased, the absolute density increased, the $d_{50}$ value decreased, and the nitrate content decreased. Accompanying these changes, the product rate decreased, the quantity of solids leaving with the scrub solution increased, the fluidized bed weight increased, the fluidized bed density increased, and the time required for 90 per cent bed replacement increased. All of these changes have been attributed to the sudden increase in alpha alumina content of the bed to 60 per cent from its previous value of 25 per cent. The factors causing this increase are believed to be complex and interwoven, and have not been isolated.

Examination of data from all ten of these runs resulted in the postulate (since proved on later runs) that the presence of a significant quantity of sodium ion in the feed is a necessary but not sufficient criterion for the production of the alpha form of alumina. Table 2 shows some data in support of this postulate.

Table 2

RELATIONSHIP BETWEEN THE ALPHA ALUMINA CONTENT OF THE PRODUCT AND PRESENCE OF SODILM IN THE FEED

\begin{tabular}{|c|c|c|c|}
\hline & Run Number & $\begin{array}{l}\text { Alpha Alumina Content } \\
\text { of Product - Per Cent }\end{array}$ & $\begin{array}{l}\text { Sodium Added } \\
\text { to Feed * } \\
\end{array}$ \\
\hline & 8 & 0 & No \\
\hline & 8 & $u$ & No \\
\hline & 8 & 0 & No \\
\hline & 8 & 40 & Yes \\
\hline & 9 & 48 & Yes \\
\hline & 9 & 67 & Ye.s \\
\hline & 9 & 68 & Yes \\
\hline & 9 & 0 & No \\
\hline & 9 & 0 & No \\
\hline * & \multicolumn{3}{|c|}{$\begin{array}{l}\text { About } 0.01 \mathrm{M} \text { sodium is present in all feed solutions; it is intro- } \\
\text { duced as a contaminant of the technical grade of al.uminum nitrate } \\
\text { used for feed preparation. When added, } 0.089 \mathrm{M} \text { additional sodium } \\
\text { was present. }\end{array}$} \\
\hline
\end{tabular}


C. Dependent Operating Variables.

Values obtained for the dependent operating variables depend upon the manner in which the calciner is operated and also upon the physical properties of the material being produced. By following closely these values during operation, changes in product properties can be detected, the over-all performance of the equipment can be ascertained quickly, and potential operating problems can be detected and corrected before they become serious.

\section{Heat Transfer Coefficients}

Over-all coefficients of heat transfer between the NaK heat transfer loop and the fluidized bed, based on the outside area of the colls, have ranged from 40 to $100 \mathrm{Btu} /(\mathrm{hr})\left(\mathrm{ft}^{2}\right)\left({ }^{\circ} \mathrm{F}\right)$; these coefficients are affected by the mass median particle diameter and to a lesser extent by the fluidized bed density. A correlation of the over-all coefficients of heat transfer (which because of the very high NaK-side coefficients are essentially equal to the fluidized bed-surface coefficient has been developed, based on a method reported by Mickley and Trilling.(12) This correlation, showing the heat transfer coefficient as a function of the dimensional ratio of the square of the fluidized bed density to the cube of the mass median particle diameter, is shown in Figure 11 . Values from this study are over double those reported by Mickley and Trilling, (12) probably because of the much wider distribution of particle sizes in the present study. The reported over-all coefficients of heat transfer were calculated from heat transfer rates determined from the measured flow rate and temperature drop of the NaK through the calciner heat exchanger. The log mean temperature difference between the measured inlet and outlet NaK temperatures and the uniform fluidized bed temperature was used as the driving force.

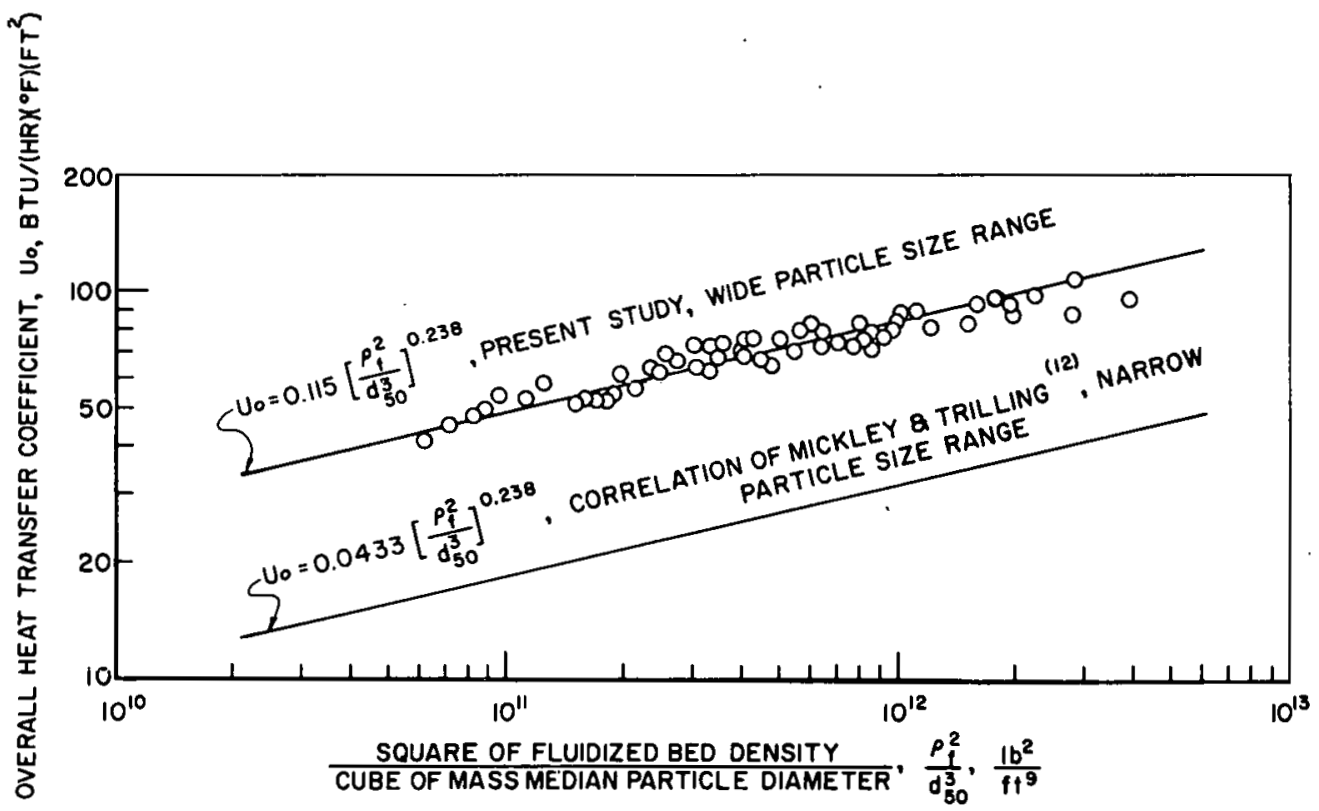

CPP-S-2233

Fig. 11 Observed Fluidized Bed Heat Transfer Coefficients 


\section{Fluidized Bed Weight}

The fluidized bed weight is determined by the pressure drop indicated across pressure probes placed beneath and above the fluidized bed. This, of course, assumes that the bed is completely fluidized. It is necessary to know the bed weight when determining the time required for replacement of any given percentage of the bed and for material balance and other calculations.

\section{Fluidized Bed Height}

The fluldized bed height is determined from a pressure drop reading taken over the lowest one-foot increment of bed and the pressure drop over the entire bed. Dividing the latter by the former gives the bed height in feet if fluidization is uniform.

\section{Fluidized Bed Dengity}

The fluidized bed density is determined by the pressure drop across the lowest foot of the bed. Changes in this value usually indicate a change in the apparent particle density, and hence bulk density, of the product. Erratic bed density values usually indicate poor fluidization or a caked bed. This reading, in conjunction with bed temperature readings, is extremely valuable in determining the onset of troubles within the fluidized bed.

\section{Product Rate and Theoretical Production Rate}

The product rate of the calciner, plotted in the data correlations in the Appendix, is based upon the average rate of product accumulation over each four-hour period. The theoretical production rates shown on. these data sheets are based on the arbitrary assumption that all of the aluminum, mercury, and sodium in the feed is calcined to the respective oxides $\left(\mathrm{Al}_{2} \mathrm{O}_{3}, \mathrm{HgO}\right.$, and $\left.\mathrm{Na}_{2} \mathrm{O}\right)$ and appears as product.

6. Time Required for 90 Per Cent Bed Replacement

The time (hours) required for a 90 per cent bed replacement is determined on the basis of a "washout" equation, wherein the bed is assumed to be perfectly mixed, the particle density is assumed to remain constant, and steady-state conditions are assumed to persist over the interval involved. The fraction of initial bed material removed at any time during a run can be calculated from the following equation:

where

$$
x=1-\bar{e} \frac{P t}{W}
$$

$$
\begin{aligned}
& \mathrm{x}=\text { weight fraction of bed removed } \\
& \mathrm{W}=\text { weight of bed, } \mathrm{kg} \\
& \mathrm{P}=\text { product rate, } \mathrm{kg} / \mathrm{hr} \\
& \mathrm{t}=\text { time, hours }
\end{aligned}
$$

Plots in the Appendix show continuous records of the value of $t$, for which $x$ is 0.9 . 


\section{Solids Leaving with the Scrub Solution}

The solids leaving with scrub solution are the fine particles elutriated from the bed which have not been removed from the off-gas stream by the primary cyclone, but have been removed by the venturi scrubber. Since the venturi scrubber removes at least 98 per. cent of the particles which enter it, the sum of the product rate and the rate at which the solids leave with the scrub solution should equal closely the theoretical product rate.

The rate at which solids leave with the scrub solution is calculated from the measured flow rate of this solution and from an analysis of it for both dissolved and undissolved solids.

\section{Effect of Operating Variables on Product Properties}

Some control of the particle size can be accomplished by increasing or decreasing the feed nozzle NAR. As has been stated previously, most of the properties exhibited by the product are functions of the alpha alumina concentration. Since conditions required for promoting or retarding the formation of the alpha alumina phase are not all known. it has not been possible to control the product properties at all times.

Quantitative effects on the product properties of varying the process variables have not yet been established. Table 3 summarizes the qualitative relationships which have been determined in these or in previous six-inch calciner runs.

\section{Table 3}

EFFECT OF CALCINER OPERATING VARIABLES

ON THE CALCINER PRODUCT PROPERTIES

Product Property
Particle Size, $d_{50}$
Absolute Material
Density
Nitrate Content

Hardne $\varepsilon \varepsilon$

BuIk Density

Alpha Content

\begin{tabular}{|c|c|}
\hline emperature & NAR \\
\hline dir & $\begin{array}{l}\text { Decreases with } \\
\text { increase in NAR }\end{array}$ \\
\hline
\end{tabular}

Not known Not known

Decreases Not known with temperature increase

Not known Not known

Decreases Not known

with temperature increase

Not known
Feed Composition

Increases when $\mathrm{Na}$ is removed

Decreases when $\mathrm{Na}$ is removed

Not known

Decreases when $\mathrm{Na}$ is removed

Decreases when $\mathrm{Na}$ is removed

Disappears when $\mathrm{Na}$ is removed 
Additional runs are being planned in the two-foot-square calciner to obtain additional quantitative information about the effect of the operating variables on the product properties. They will include runs designed to determine the effects of feed composition, calcination temperature, nozzle design, and fluidizing velocity on the physical and chemical properties of the calcined product.

E. Comparison of In-Bed Samples with Overflow Product

1. In-Bed Samples: Taken During Runs

Samples obtained by means of the in-bed sampler were compared with those taken from the overflow product. The majority of the in-bed samples contained more fines than comparative samples from the product, which may be due to attrition in the sampler lines. A comparison of typical in-bed samples and overflow product samples is shown in Table 4.

Table 4

COMPARTSON OF IN-BED SAMPLES WITH OVERRLOW PRODUCT

Typical Simultaneously Sampled Product and

In-Bed Samples on Run 1

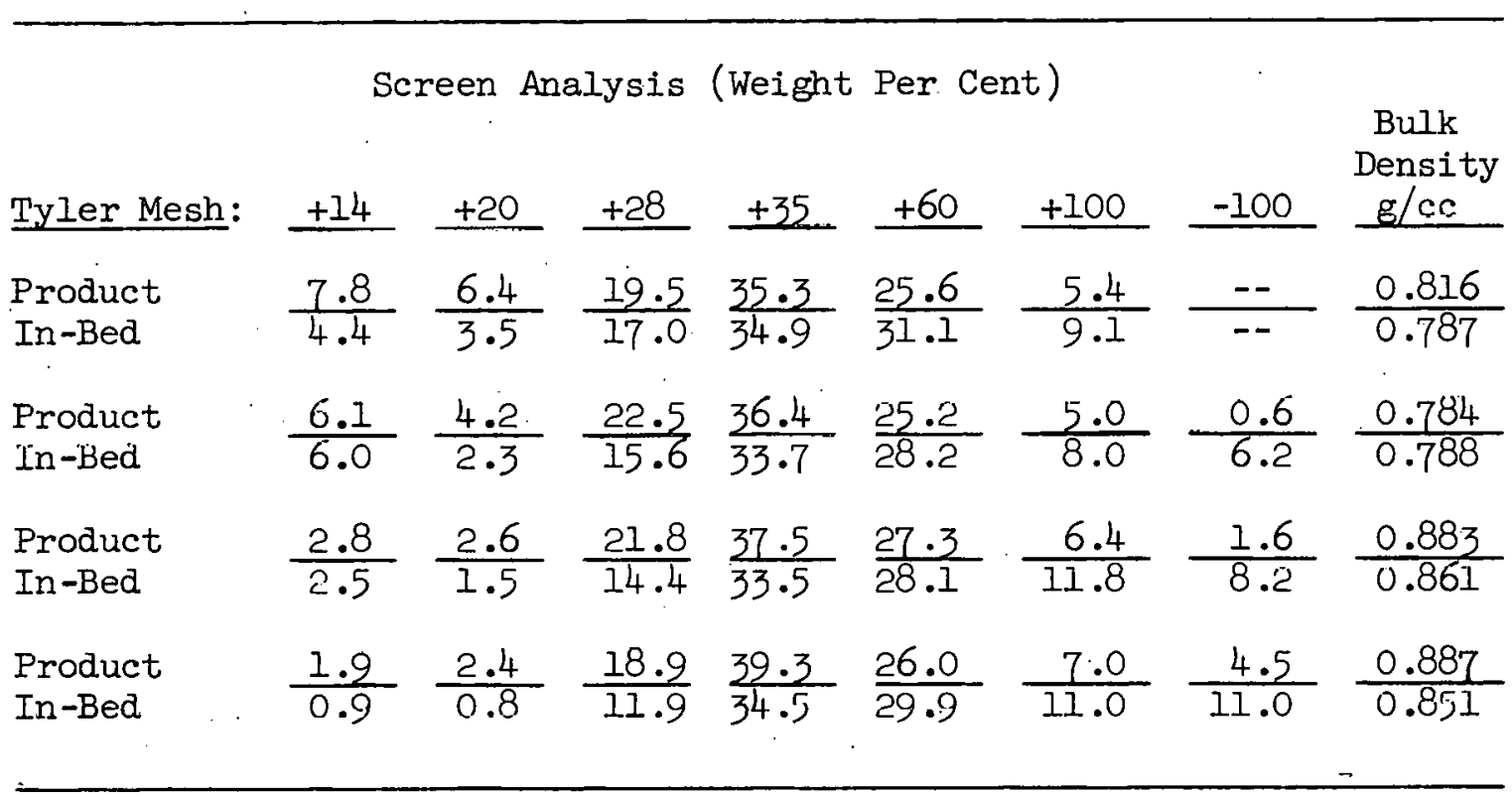

\section{Samples Taken from Bed After Run Termination}

At the conclusion of Run 10, the bed was thoroughly sampled. Thirty-nine samples were taken by aspiration, 13 near the top of the bed, 13 near the middle of the bed, and 13. near the bottom of the bed. Each sample was analyzed for bulk density and particle size distribution; the data were then analyzed statistically. Four of the samples, those from the lower corners of the bed, showed slight but statistically significant differences in particle size distribution when compared with 
the average of the others. One sample, taken from a position near a viewing port ledge, had a particle size distribution which did not agree with the other samples. The close agreement of the other 34 samples was an indication that excellent fluidization uniformity existed in the bed. A comparison of the average shutdown sample analyses with the two preceding overflow product sample analyses taken during this near-steadystate period of operation is given in Table 5 .

Table 5

A COMPARISON OF IN-BED SAMPIES WITH PRODUCT SAMPLES ON RUN 10

\begin{tabular}{|c|c|c|c|c|c|c|c|c|}
\hline \multirow[b]{2}{*}{ Sample } & \multirow{2}{*}{$\begin{array}{l}\text { Bulk } \\
\text { Density } \\
\text { g/cc } \\
\end{array}$} & \multicolumn{2}{|r|}{ Screen } & \multicolumn{3}{|c|}{ Analysis (Weight Per } & \multicolumn{2}{|l|}{ Cent) } \\
\hline & & +14 & +20 & +28 & +35 & +60 & +100 & -100 \\
\hline $\begin{array}{l}\text { Average of } \\
34 \text { aspirated } \\
\text { samples }\end{array}$ & 0.90 & 0.1 & 1.3 & 29.5 & 44.2 & 21.1 & 3.3 & 0.5 \\
\hline $\begin{array}{l}\text { Overflow produc } \\
\text { sample just } \\
\text { before shutdown }\end{array}$ & 0.90 & Trace & 1.3 & 31.5 & 44.5 & 19.8 & 3.0 & Trace \\
\hline $\begin{array}{l}\text { Overflow produc } \\
\text { sample } 4 \text { hours } \\
\text { before shutdown }\end{array}$ & 0.90 & Trace & 1.3 & 30.8 & 43.9 & $20 . .2$ & 3.8 & Trace \\
\hline
\end{tabular}




\section{CONCLUSIONS}

The following conclusions can be drawn from the operating experiences and data obtained from the first ten extended runs made in the two-foot-. square calciner:

1. Equipment and operating techniques were developed to the point where a voluntarily terminated continuous run of 43 days was achieved.

2. A liquid metal (NaK) system is a reliable and effective method of supplying heat to a fluidized bed calciner. Because of the high temperatures possible with such a system $\left(1400^{\circ} \mathrm{F}\right)$, large amounts of heat can be transferred to the process materlals with a minimum of heat transfer surface.

3. A tube-side-fired heat exchanger in which combustion gases are the heat transfer medium is a promising alternate method for supplying heat to the process. With a modest development effort, it is possible that a reliable, inexpensive, and compact system of this type could be designed.

4. A properly designed fluidizing gas distributor and bed support plate is essential if good fluidization is to be obtained in the calciner. The pressure drop of the fluidizing gas. across the bed support plate should be at least 40 per cent of that across the bed.

5. The design feed rate of 100 litèrs per hour at a calcination temperature of $400^{\circ} \mathrm{C}$ was easily reached in the two-foot-square calciner. Even at a calcination temperature of $500^{\circ} \mathrm{C}$, a feed rate of 100 liters per hour was effectively employed.

6. An instantaneous sample of the bed was obtained with the aid of an in-bed sampler. The sample obtained with this in-bed sampler consistently contained more fine material than that obtained from the overflow product line.

7. Large masses of caked bed, which on occasion developed around the feed nozzles and the heat exchanger due to maloperation or the use of unsuitable operating conditions, could be removed by boiling for several hours in dilute nitric acid.

8. The calciner was operated successfully with superficlal fluidizing velocities of from 0.5 to 1.0 foot per second.

9. Over-all heat transfer coefficients have ranged from 40 to 100 $\mathrm{Btu} /(\mathrm{hr})\left(\mathrm{ft} \mathrm{t}^{2}\right)\left({ }^{\circ} \mathrm{F}\right)$. High coefficients are associated with beds having small particle sizes and high fluidized bed densities, whereas low coefficients are associated with beds having large particle sizes and low fluidized bed densities.

10. The calciner has been operated with nozzle air-to-liquid volume ratios (NAR) from 195 to 486. The two-foot-square calciner product particle size responds to changes in NAR in the same direction as did 
product from the six-inch calciner; high NAR values generally result in a product having a small average diameter, whereas low NAR values result in a large average product particle size.

11. At least under conditions employed on a single test, only about 20 per cent of the fines leaving the calciner with the off-gas were produced by the fluidizing action in the bed alone; the remaining 80 per cent were formed as a result of the feed nozzle and feed nozzle interactions with the bed.

12. Although not always obtained during these runs, a desirable product should have a mass median particle diameter between 0.25 and $0.60 \mathrm{~mm}$ to provide good heat transfer rates and permit use of a wide range of fluidizing velocities without incurring excessive particle carryover.

13. Product bulk densities have varied during these runs between 0.60 and $1.28 \mathrm{~g} / \mathrm{cc}$.

14. Product absolute material densities have varied from 2.6 to $3.8 \mathrm{~g} / \mathrm{cc}$.

15. Product apparent particle densities have varied from 1.0 to $1.8 \mathrm{~g} / \mathrm{cc}$.

16. A straight-line relationship exists between the product bulk density and the product apparent particle density. The product apparent particle density is 1.7 times as great as the product bulk density, thus indicating a constant void fraction of 0.41 .

17. Product intra-particle porosities measured on Run 10 averaged 0.60 ; measurements could not be made on earlier runs.

18. Product nitrate content has varled during these runs from 0.22 to 0.95 millimole of nitrate per gram of product.

19. Product hardness has varied from less than 120 to 460 grams, based on an empirically developed test.

20. Generally, only two phases of alumina were produced during the calcination process, amorphous and alpha. Most of the product properties were related to the relative abundance of these phases. Product having a high concentration of alpha alumina was harder to crush, was more dense, had a lower nitrate content, and was more friable than that having a low alpha alumina concentration.

21. An increase in the rate of formation of alpha alumina was found to be associated with the sodium content of the feed; a feed containing about $0.1 \mathrm{M}$ rather than $0.01 \mathrm{M}$ sodium was a necessary but not a sufficient condition for formation of detectable quantities of alpha alumina in the calciner.

Other factors influencing the rate of formation of alpha alumina in the calciner were not defined by these studies; therefore, no method 
was developed of controlling, in a reliable manner, the product properties. The apparently erratic behavior associated with the product properties observed during many of the runs was attributed to uncontrolled alpha alumina formation.

22. Off-gas solids loading in the gas leaving the calciner during periods when dry fines were not returned to the bed varied from $3 \cdot$ to 120 . per cent of the product rate, depending primarily on the alpha alumina content of the bed. Data were not obtained on off-gas loading when dry fines were returned to the bed. 
The efforts of literally dozens of individuals combined to make possible the work reported herein. Individual recognition of all persons associated with the work is not possible in this short space, but some names may be mentioned.

Particular recognition is due C. E. Stevenson and D. M. Paige for their early direction of the work and for their encouragement throughout all early difficulties.

Development of a reliable NaK heating system was achieved largely through the efforts of $G$. E. Lohse.

The Chemical Engineering Laboratory operators are due special thanks for their untiring, careful efforts.

The many members of the ICPP Analytical Section, under the direction of $R$. C. Shank, should receive credit for development of several of the analytical methods employed in this work and for careful analysis of thousands of samples.

To these persons, and to the many others who shared in this work, the authors are deeply grateful. 
1. Morgan, J.M., Jr., Editor, Report of Working Meeting on Fixation of Radioactivity in Stable, Solid Media, held at the Johns Hopkins University, June 19-21, 1957, TID-7550, March, 1958

2. Morgan, J.M., Jr., Editor, Report of Second AEC Working Meeting on Fixation of Radioactivity in Stable, Solid Media, held at Idaho Falls, Idaho, September 27-29, 1960, TID-7613.(2 books), July, 1961

3. Symposium on the Reprocessing of Irradiated Fuels, held at Brussels, Belgium, May 20-25, .1957, TID-7534 (1957)

4. Jonke, A. A., E. J. Petkus, J. W. Loeding, and S. Lawroski, Nuclear Science and Engineering, $\leqq 303-319$, (1957)

5. Grimmett, E. S., Calcination of Aluminum-Type Reactor Fuel Wastes in a Fluidized Bed, IDO-14416, August, 1957

G. Lapple, C. E., Fluld and Parllele Mechlanlis, 307, Unlverslly ur Delaware Press, Newark, Delaware (1956)

7. Evans, D. R., Pilot Plant Studies with a Six-Inch Diameter Fluidized Bed Calciner, ID0-14539, April, 1961

8. Loeding, J. W., E. L. Carls, L. J. Anastasia, and A. A. Jonke, The Fluid-Bed Calcination of Radioactive Waste, ANL-6322, May, 1961

9. Macqueen, D. K. and J. I. Stevens, Design Bases for ICPP Waste Calcination Facility, IDO-14462, April, 1959

10. Zenz, F. A. and D. F. Othmer, Fluidization and Fluid-Particle Systems, 260, Reinhold Publishing Corp., New York, N. Y. (1960)

11. Wheeler, B. R., Venturi Scrubber Evaluation for Waste Calcination Off-Gas Facilities, IDO-14484, December, 1959.

12. Mickley, H. S. and C. A. Trilling, Ind. and Eng. Chem., 41 , $1135-1147$ (1949)

13. Cartan, F. O. and G. J. Curtis, Contribution in Manual of Analytical Methods Used by the Control Laboratory at the Chemical Processing Plant, IDO-14316, October, 1961 


\section{APPENDIX}

\section{A. Detailed Description of NaK Heating System}

\section{System Description}

Demonstration of the operability of the NaK heating system, shown in Figure 5, at temperatures up to $1400^{\circ} \mathrm{F}$ was an important objective of these studies. A detalled description of this system follows.

The oil-fired furnace is a commercially built direct-fired radiant heater. The furnace has a NaK heating coil consisting of two circular headers with vertical interconnecting tubes. The two headers are 3 -inch $0 . d$. by 0.1875 -inch wall thickness, stainless steel Type 316 tubing; the top and bottom headers have a $20 \frac{1}{2}$-inch and a $14 \frac{1}{2}$-inch radius, respectively. The headers are about four feet apart, with 35 vertical tubes, 0.840 -inch $0 . d$. by 0.109 -inch wall thickness, stainless steel Type 316, equally spaced and welded to the headers. The coil has 38 square feet of effective radiant heat absorption surface.

The calciner heat exchanger bundle consists of horizontal inlet and outlet manifolds, each 2 inches $0 . d$. by $1 \frac{1}{4}$ inches $1 . d$., stainless steel Type 316 tubing with twelve 3/4-inch 0.d., 14 BWG Carpenter-20 coiled tubes welded to the manifolds. The bundle has 28 square feet of outside heating surface in the calciner. Details of the bundle are shown in Figure 12. Dotted lines indicate the original position of the NaK inlet and outlet headers; these were changed after excessive thermal stresses resulted in two leaks.

The electromagnetic pump used is a Callery Chemical Company Style 25-30. a.c. conduction-type pump which can deliver 13,000 pounds per hour of NaK at a developed pressure of 10 psig. The NaK flow rate is determined by the measured pressure difference across the electromagnetic pump and a calibration chart supplied by the manufacturer.

The NaK transfer lines are Schedule $80,1 \frac{1}{2}$-inch, stainless steel Type 304 pipe, and the surge and storage vessels are stainless steel Type 316 with $1 / 4-$ inch wall thickness.

Controls for the system include an electronic-pneumatic temperature recorder-controller that controls the air to the burmer. The air to the burner in turn controls the oil through an air-to-oil Ratiotrol. An indicating pyrometer controller with a thermocouple welded to the NaK outlet line from the furnace stops the flow of oil to the furmace when the $\mathrm{NaK}$ outlet temperature exceeds $1400^{\circ} \mathrm{F}$. This temperature is controlled to insure that the bolling temperature ( $1444^{\circ} \mathrm{F}$ at 1 atmosphere) of the NaK is not exceeded. An electrical resistance placed across the NaK surge tank activates an alarm when the NaK level drops below a safe level. The NaK system can be dumped to the storage tank by manually activating the solenoid valves. 


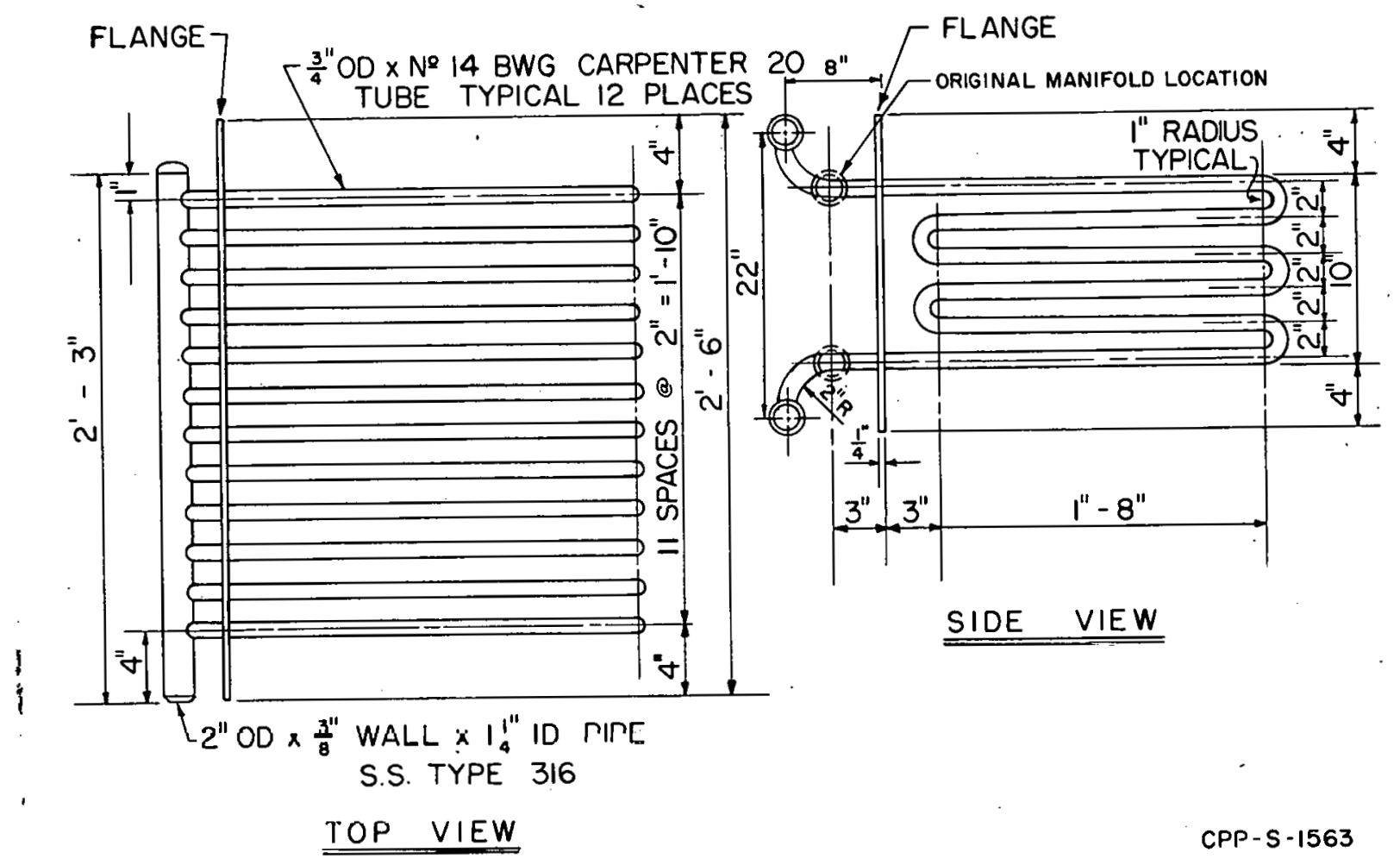

Fig. 12 Calciner Heat Exchanger Bundle

\section{2.' Operating Problems}

After approximately 2100 hours of operating time, the electric power input lines to the electromagnetic NaK pump failed. These lead wires were designed to operate at the temperatures and amperages required for this type of service, having been Type A-1, No. 14 AWG, with a rating of 30 amperes at $125^{\circ} \mathrm{C}$. They were replaced with Type A-2, No. 12 AWG, with a rating of 40 amperes at $200^{\circ} \mathrm{C}$. For each lead, two wires were run parallel in order to halve the current. Since this alteration, no further pump lead failures have occurred.

The two NaK leaks external to the calciner occurred 60 hours apart, the f'irst one after the system had been operated for 2825 hours and after 73 start-ups. This crack occurred at a point where the first of twelve Carpenter-20 alloy tubes was welded to a two-inch o.d b manifold of stainless steel Type 316. The crack was repaired by welding and the system was put back into service.

The second leak was detected at a point where the twelfth tube was welded to a Carpenter-20 alloy tube sheet. A metallurgical examination of the coil and of a short section of the NaK loop was performed. 
Failure at the weld zone (stainless steel Type 316 to Carpenter-20) was due to a transgranular crack, probably caused by repeated thermal cycle overstressing. Insignificant amounts of surface corrosion on the NaK side of the tube and loop specimens were measured.

B. Run Data Summary

Important data obtained during the first ten calcination runs are summarized here. Prior to these runs, a few exploratory runs were made, including previously mentioned tests with a tube-side-fired heat exchanger. 
$\underline{\text { Run 1. }}$

Period Covered: From January 19, 1959 to March 11, 1959

Objective: This was the first run of a statistical program designed to relate the product and off-gas characteristics with the calciner operating conditions. Equipment development and evaluation was another objective.

Equipment: The equipment used in this run was essentially. that shown in Figure 1. Combustion gases from the oil-fired burner were used as the fluidizing medium. The air distributor plate used was the one shown in Figure 4.

Cumulative NaK Heating System Operating Data (including this run):

50 start-ups; 1165 hours above $1000^{\circ} \mathrm{F} ; 422$ houre below $1000^{\circ} \mathrm{\Gamma}$.

Run Conditions:

Bed temperature, ${ }^{\circ} \mathrm{C} \quad 500$

Feed rate, I/hr 40

Nozzle air-to-liquid volume ratio 376

Number of Spraying Systems Company Type 1/4 J nozzles 4

Total nozzle air rate, scfm

Superficial fluidizing velocity, ft/sec

Initial

Changed on January 22 to

0.30

0.64

Feed Composition: Aluminum nitrate, M 1.95

Nitric acid, $\overline{\mathrm{M}} \quad 1.25$

Sodium nitrate, $\overline{\mathrm{M}} \quad 0.089$

Mercuric nitrate, $\bar{M} \quad 0.006$

Results: Results significant to the statistical program were not obtained during this run because steady-state operation was not achieved. However, operating experience and techniques were acquired, and evaluation of equipment was made.

Difficulties: Most of the troubles occurred with the oilfired fluldizing air preheater and the feed rate controllers. A fluidizing velocity of $0.3 \mathrm{ft} / \mathrm{sec}$ gave poor bed fluidization; therefore, during the run this value was increased to $0.64 \mathrm{ft} / \mathrm{sec}$. 
CALCINER 2 - FT. RUN No.

FEED RATE $40 \mathrm{l} / \mathrm{hr}$. BED TEMP $500^{\circ} \mathrm{C}$

NOZZLES: No. 4

TYPE $S S-\frac{1}{a}$
SUPERFICIAL FLUIDIZING VELOCITY $-0.3 \rightarrow 0.64 \mathrm{ft} / \mathrm{sec}$

DRY FINES RETURN 11.3

scfm
FEED:

$\mathrm{Al}\left(\mathrm{NO}_{3}\right)_{3} \quad 1.95$

$\mathrm{HNO}_{3}-1.25$
$\mathrm{NaNO} 30.089$

$\mathrm{Hg}\left(\mathrm{NO}_{3}\right)_{2} \underline{0.006} \underline{\mathrm{M}}$

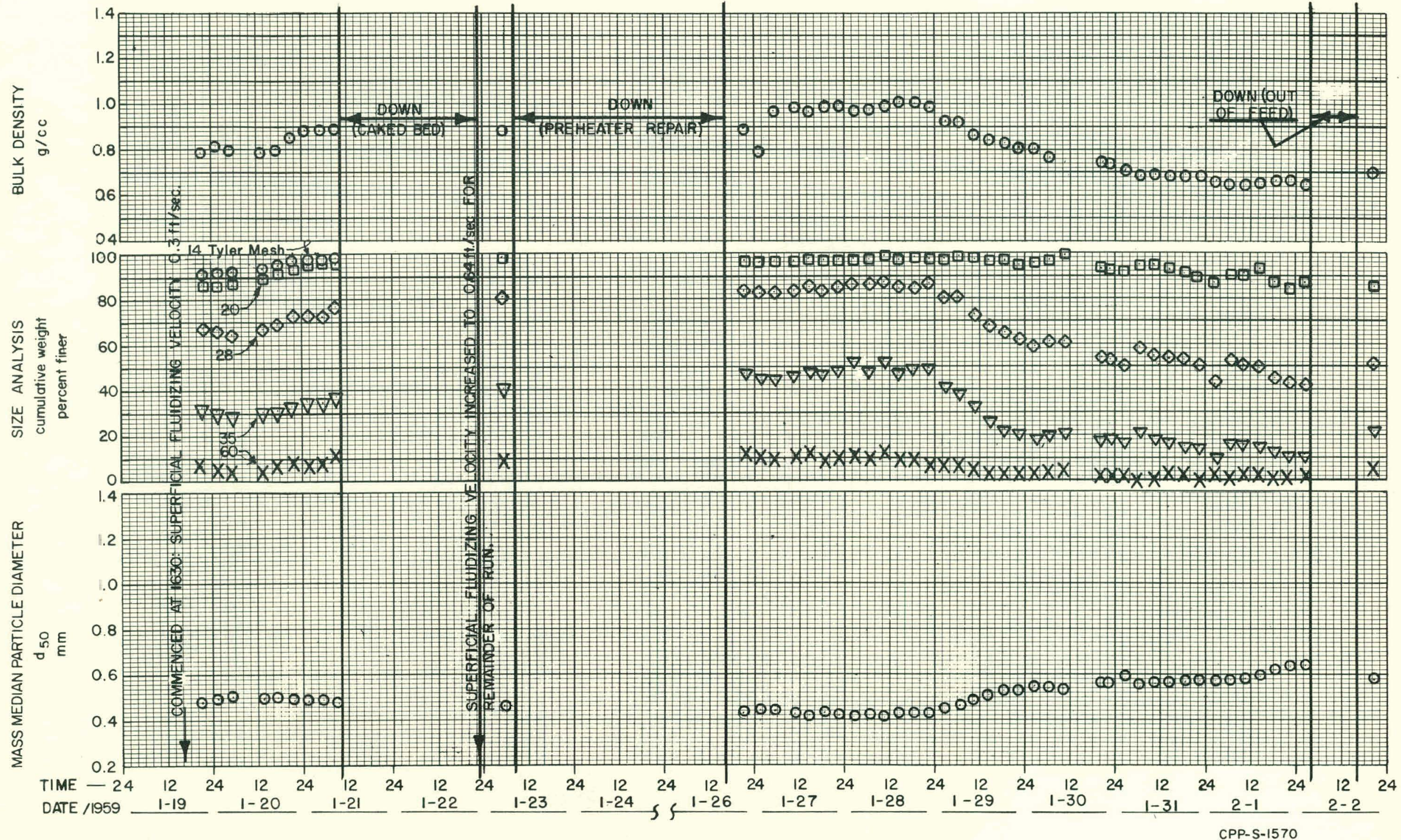

Fig. 13 Product Data, Run 1 (Sheet 1 of 4 ) 
CALCINER 2-Fi RUN No. 1

FEED RATE $40 \mathrm{l} / \mathrm{hr}$. BED TEMP. $500{ }^{\circ} \mathrm{C}$

SUPERFICIAL FLUIDIZING VELOCITY0.3 $\rightarrow 0.64 \mathrm{ft} / \mathrm{sec}$

DRY FINES RETURN 11.3

NOZZLES: NO. 4 TYPE SS I/4-J AIR-TO-LIQUID VOLUME RATIO 376
FEED:

$\mathrm{Al}(\mathrm{NO} 3) 3-1.95-\mathrm{M}$

$\mathrm{NaNO}+0.089 \mathrm{M}$

$\mathrm{HNO}_{3}-\frac{1.25}{-M}$

$\mathrm{Hg}\left(\mathrm{NO}_{3}\right)_{2} 0.006 \mathrm{M}$

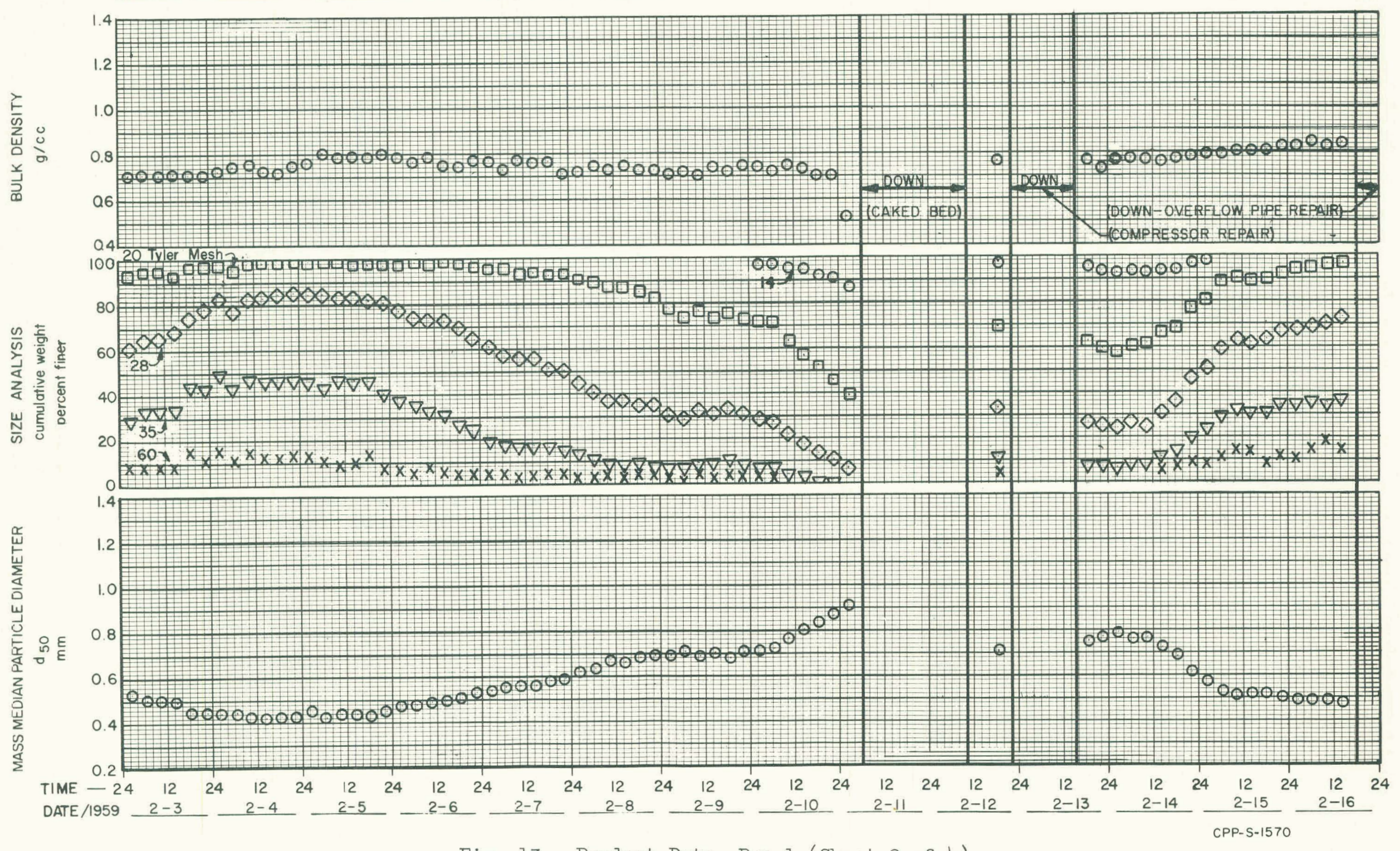

Fig. 13 Product Data, Run 1 (Sheet 2 of 4 ) 


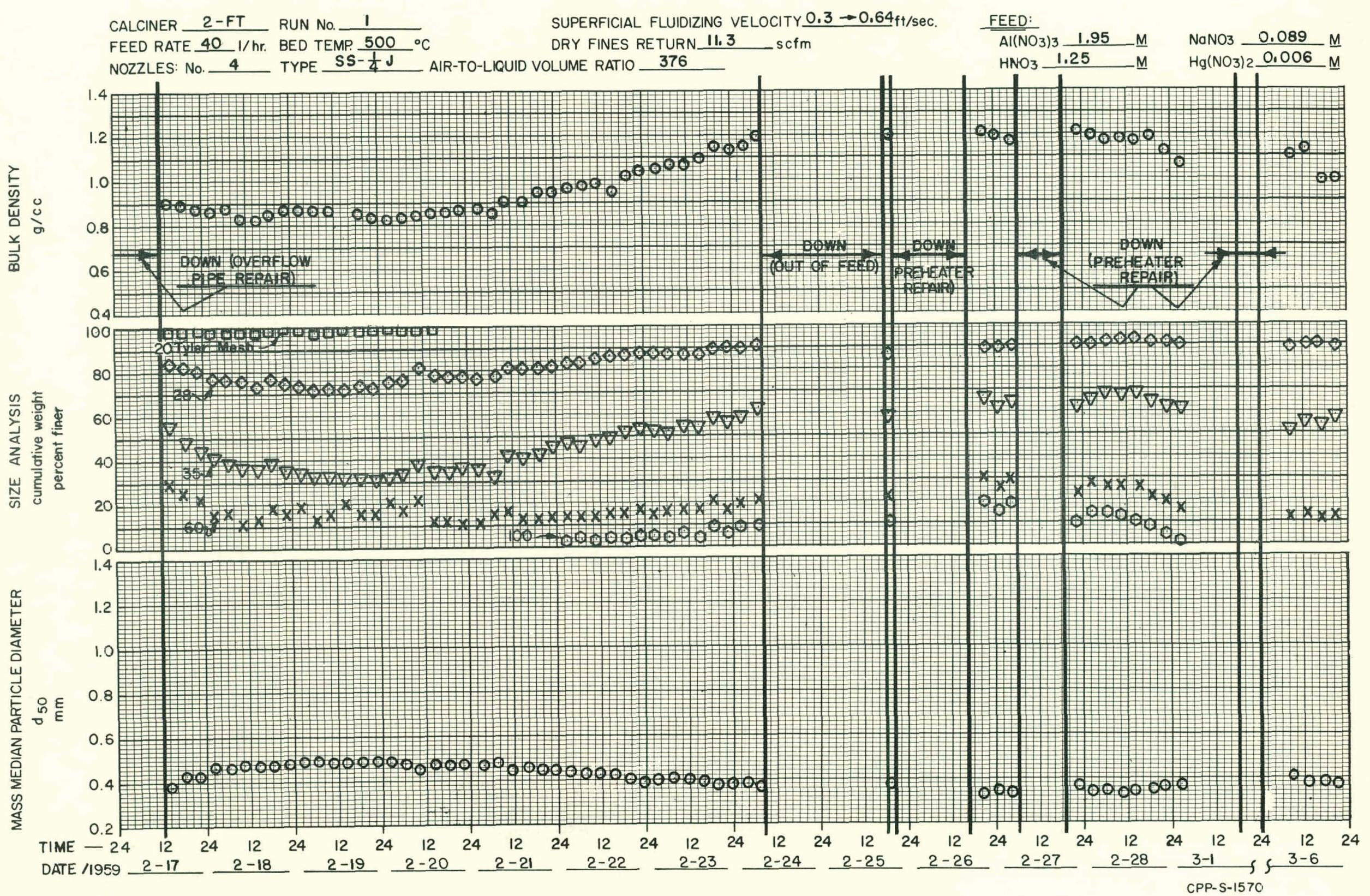

Fig. 13 Product Data, Run 1 (Sheet 3 of 4 ) 
CALCINER 2-FT RUN No.

FEED RATE $40 \mathrm{l} / \mathrm{hr}$. BED TEMP. $500{ }^{\circ} \mathrm{C}$

4 TYPE $S S-\frac{1}{4}$ AIR-TO-LIDUID VOLUME RATIO 376
SUPERFICIAL FLUIDIZING VELOCITY $0.3 \rightarrow 0.64 \mathrm{ft} / \mathrm{sec}$.

DRY FINES RETURN_ 11.3 scfm
FEED:

$\mathrm{Al}\left(\mathrm{NO}_{3}\right) 3 \quad 1.95 \quad \mathrm{M}$

$\mathrm{HNO}_{3}$
$\mathrm{NaNO}_{3} \quad 0.089 \mathrm{M}$ $\mathrm{Hg}\left(\mathrm{NO}_{3}\right)_{2} 0.006$ M

衣

1.

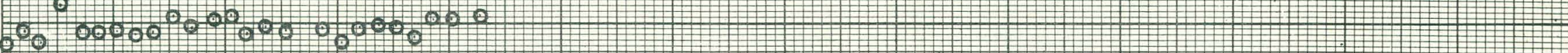

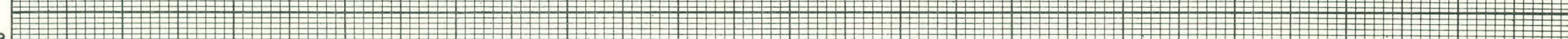

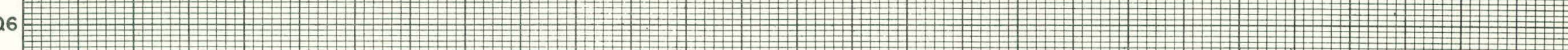
Q

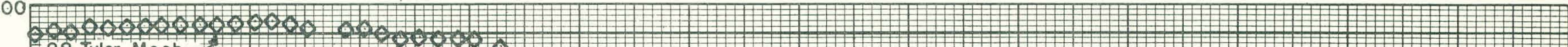

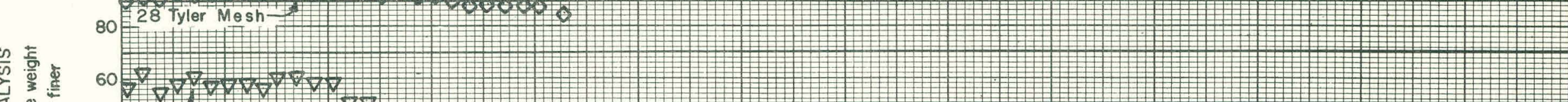

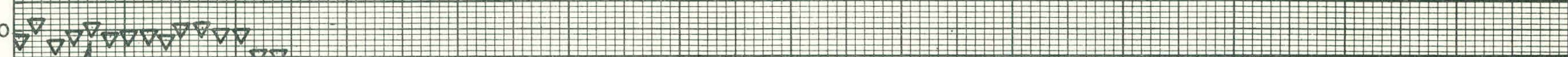

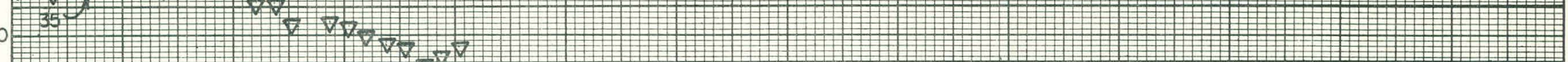

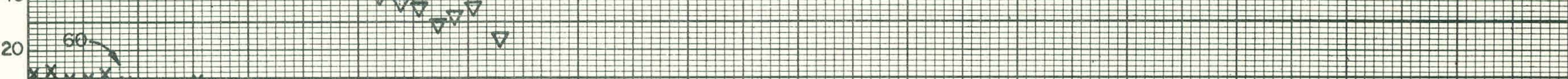

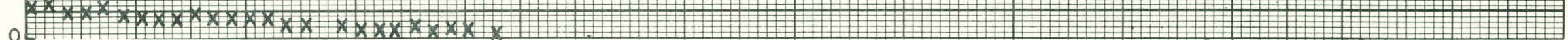
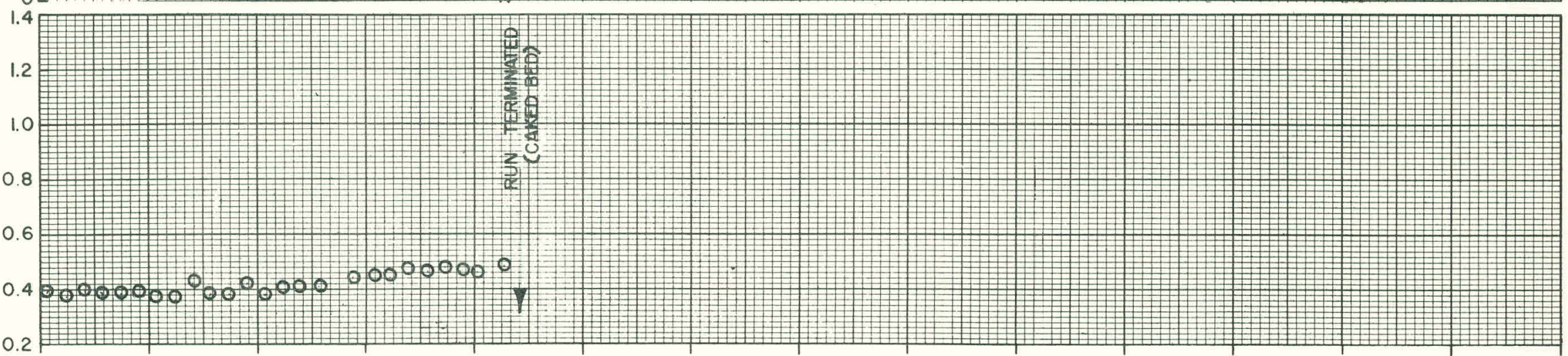

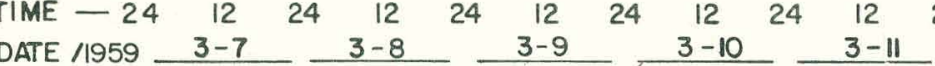

Fig. 13 Product Data, Run 1 (Sheet 4 of 4 ) 


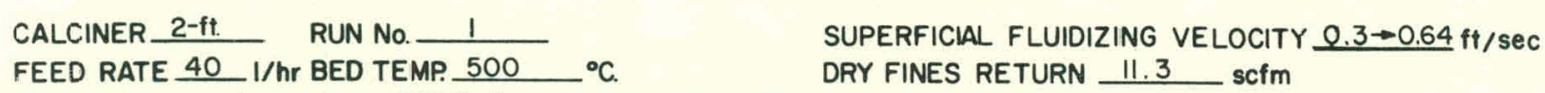
NOZZLES: 4 TYPE SSI/4-J AIR-TO-LOUID VOLUME RATIS RETURN 11.3 scfm
EEED:

$A I\left(\mathrm{NO}_{3}\right)_{3} \frac{1.95}{\mathrm{M}} \mathrm{NaNO}_{3} \frac{0.089}{\mathrm{M}}$ $\mathrm{HNO}_{3} \mathrm{I} .25 \mathrm{Mg}\left(\mathrm{NO}_{3}\right)_{2}$
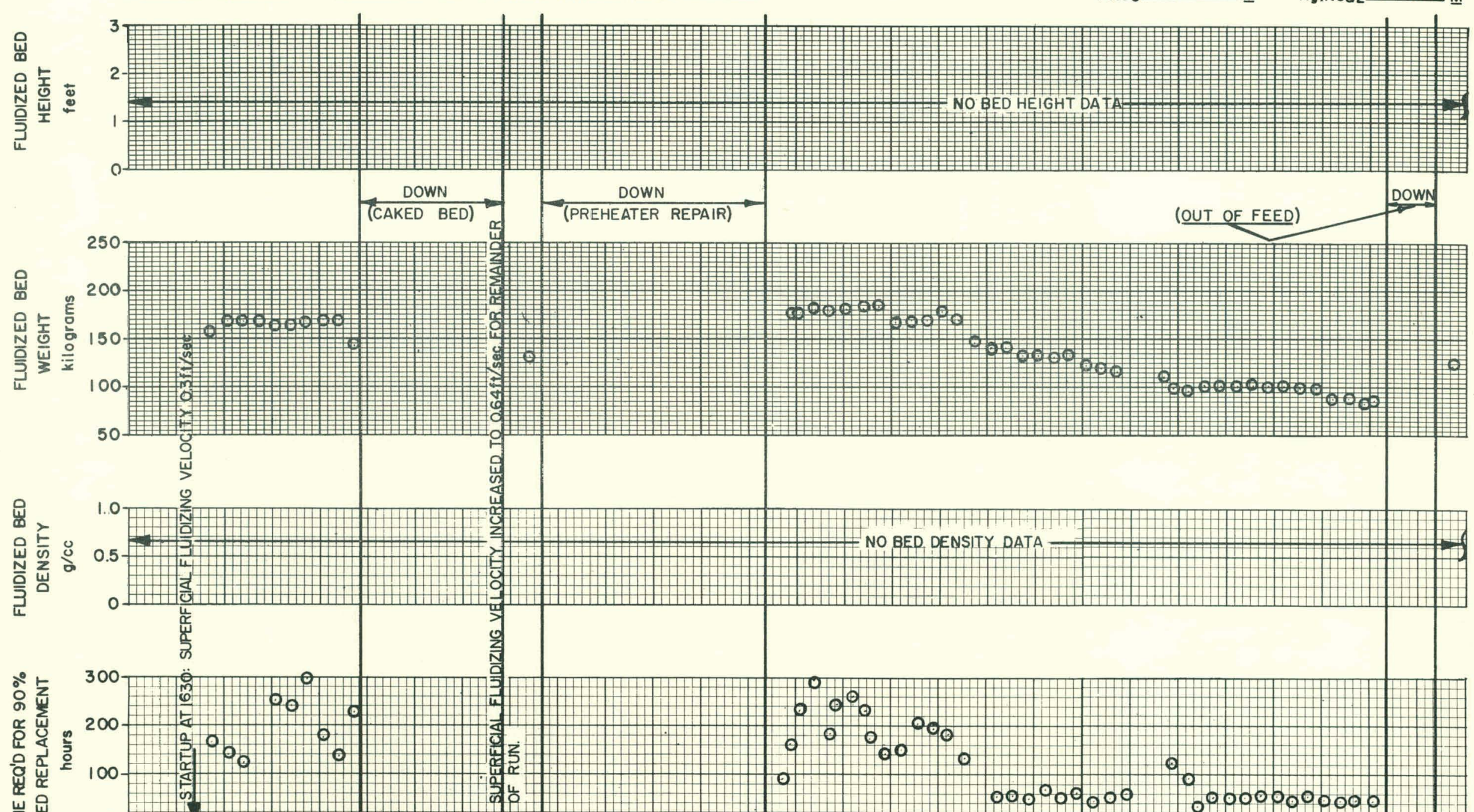

崖㟧
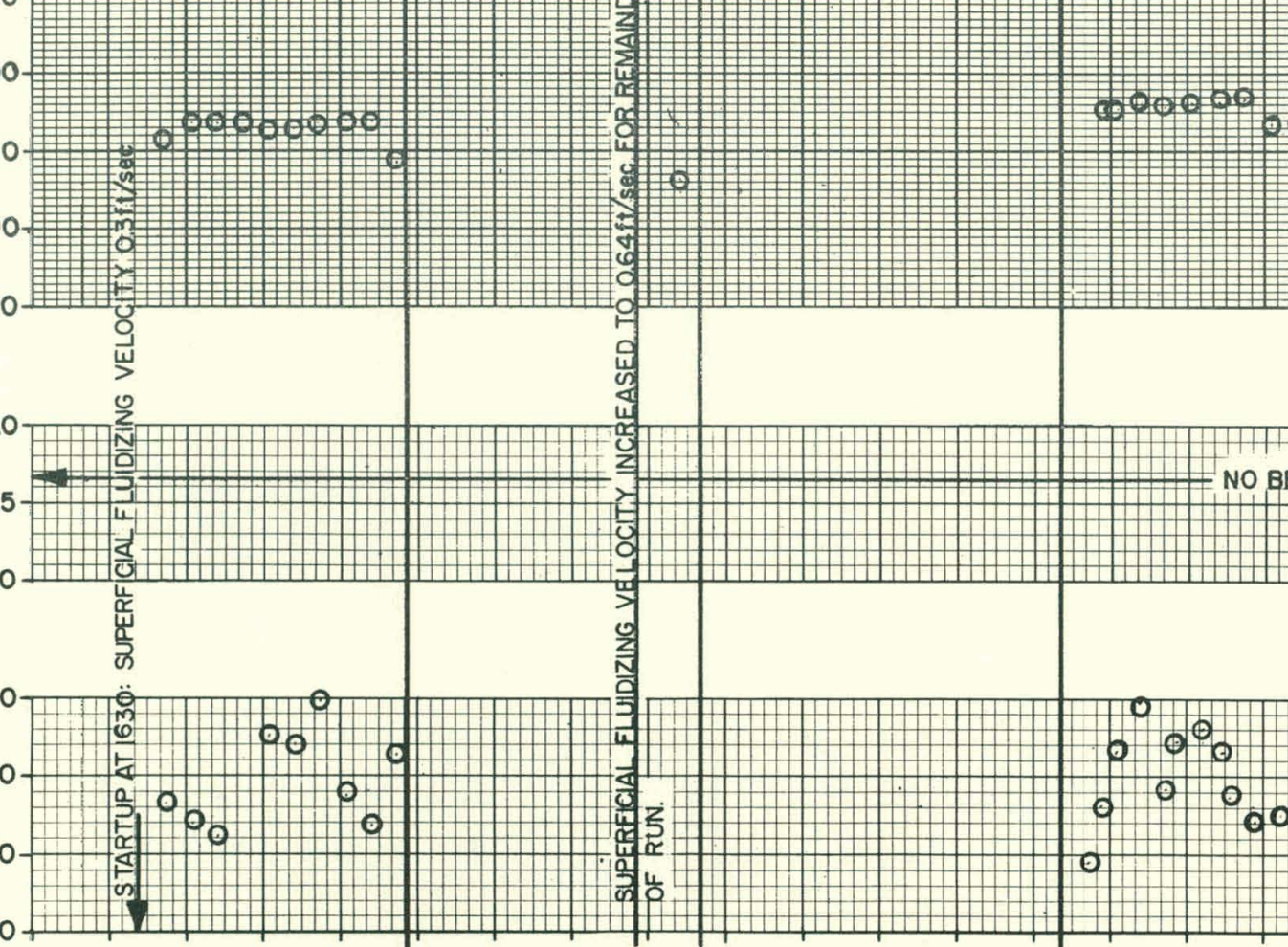

\section{(1)}

$+$ $\frac{1000}{00}$

$\begin{array}{llllllllllllllll}\text { TIME } & - & 24 & 12 & 24 & 12 & 24 & 12 & 24 & 12 & 24 & 12 & 24 & 12 & 24 & 12\end{array}$

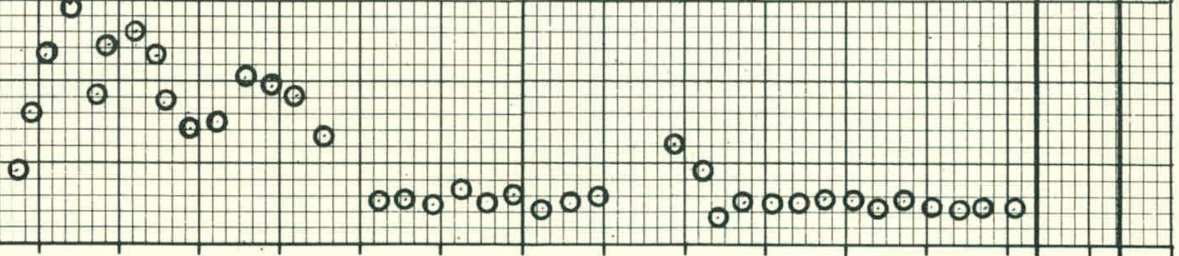
DATE/ $1959 \quad 1-19 \quad 1-20 \quad 1-21 \quad 1-22 \quad 1-23 \quad 1-24 \quad 1-26$

$\begin{array}{llllllll}24 & 12 & 24 & 12 & 24 & 12\end{array}$

Fig. 14

Calciner Bed Data, Run 1 (Sheet 1 of 4 )

CPP-S-1571 
CALCINER_2 FT RUN NO.

FEED RATE $40 \mathrm{l} / \mathrm{hr}$ BED TEMP. $500 \quad{ }^{\circ} \mathrm{C}$

NOZZLES: NO. 4 TYPE_SS-1/4 N AIR-TO-LIQUID VOLUME RATIO 376
SUPERFICIAL FLUIDIZING VELOCITY $\underline{0.3 \rightarrow 0.64} \mathrm{ft} / \mathrm{sec}$

DUY FINES RETURN 11.3 scfm
FEED:

$\mathrm{Al}\left(\mathrm{NO}_{3}\right)_{3} \quad 1.95-\mathrm{M} \quad \mathrm{NoNO}_{3} \quad 0.089$ $\mathrm{HNO}_{3} \quad 1.25-\mathrm{M} \quad \mathrm{Hg}\left(\mathrm{NO}_{3}\right)_{2}-0.006$ M
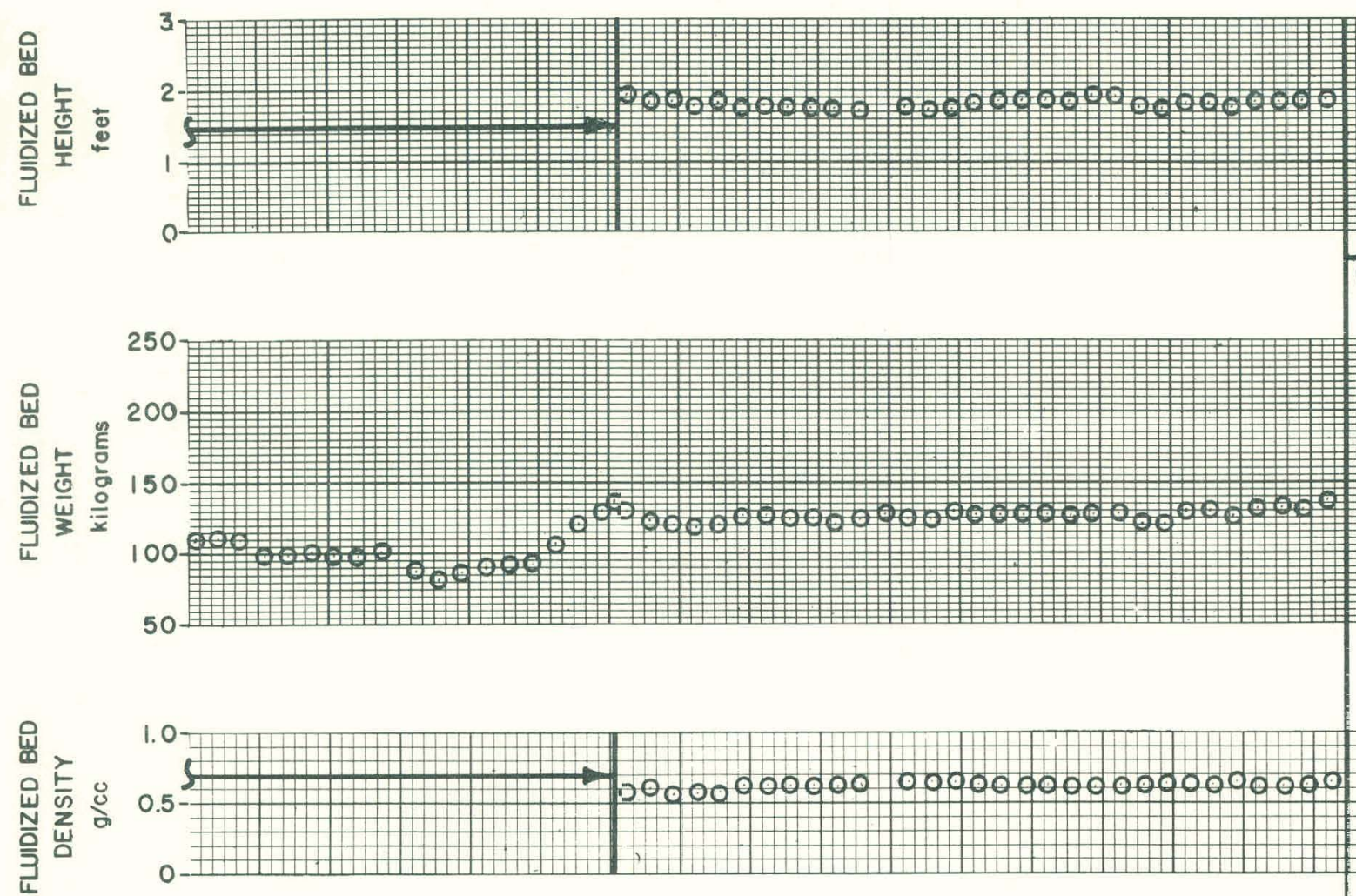

\section{0}

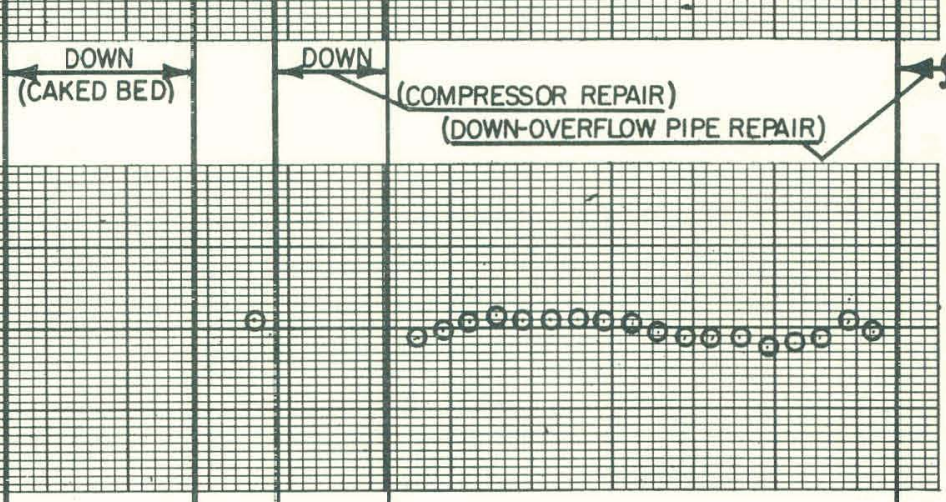

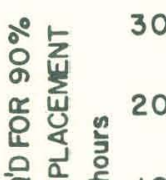

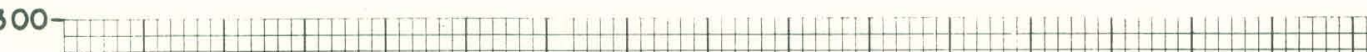

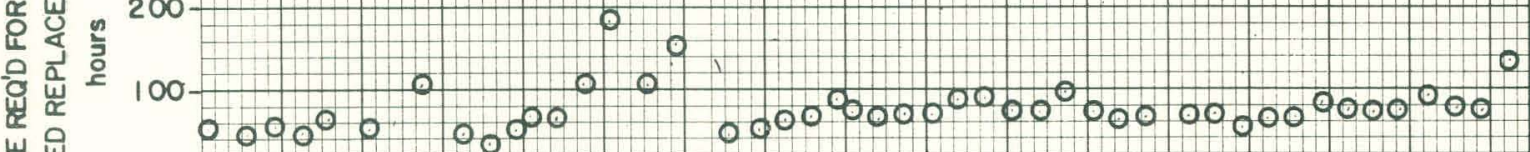

崖

$0000^{0} 0.00$

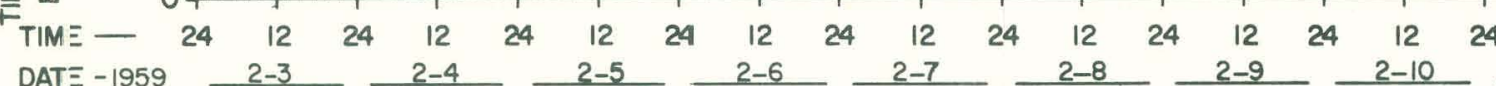

DAT $=-1959 \quad 2-3$

Fig. 14

Calciner Bed Data, Run 1 (Sheet 2 of 4 )
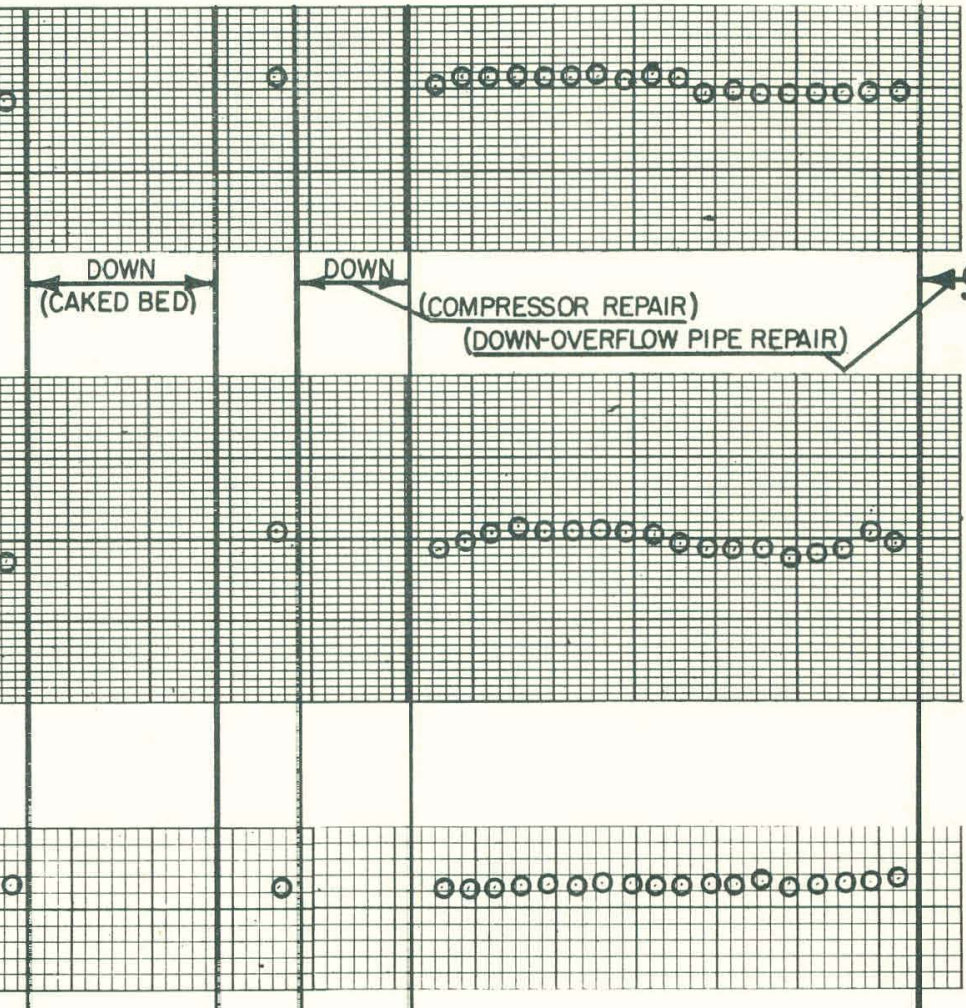

0.0000000000000

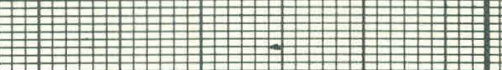

MOMESSOR REPAIR || |||| $0000000000^{0000000 \mid}$ 
CALCINER 2 2 FT. RUN No. 1 FEED RATE $4 \mathrm{C} \mathrm{I} / \mathrm{hr}$ BED TEMP. $500{ }^{\circ} \mathrm{C}$ ${ }^{\circ} \mathrm{C}$
SUPERFICIAL FLUIDIZING VELOCITY $0.3 \rightarrow 0.64 \mathrm{ft} / \mathrm{sec}$ DRY FINES RETURN 11.3

UME RATIO 376
EEED:

$\mathrm{Al}\left(\mathrm{NO}_{3}\right)_{3} \quad 1.95$

$\mathrm{HNO}_{3} \quad \mathrm{I} .25 \mathrm{M}$
$\mathrm{NaNO}_{3} \mathrm{O} 089$

$\mathrm{Hg}\left(\mathrm{Na}_{3}\right)_{2} 0.0006$

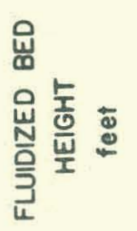

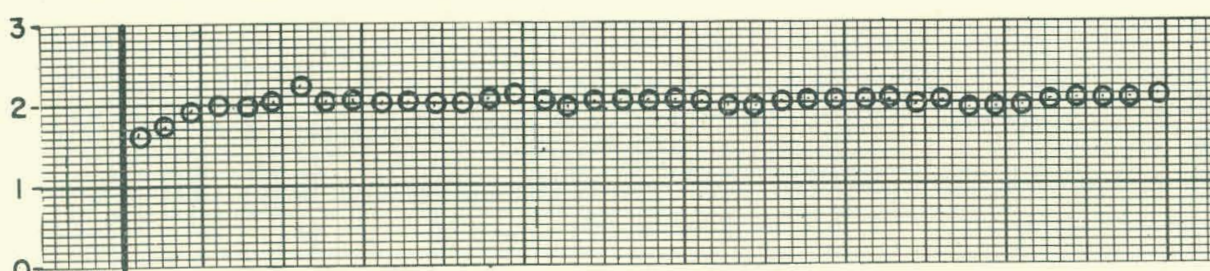

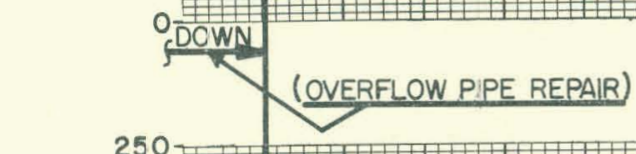

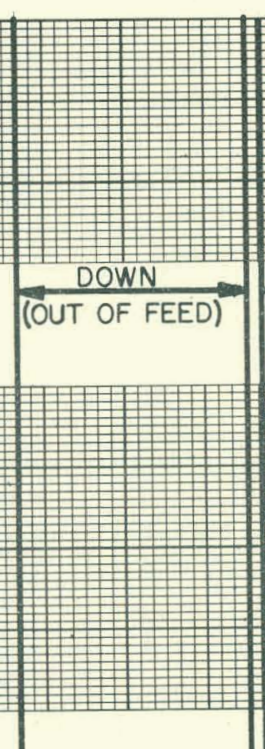

50 -

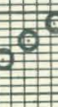

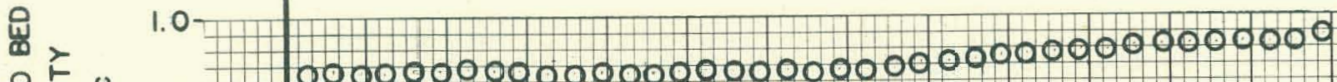

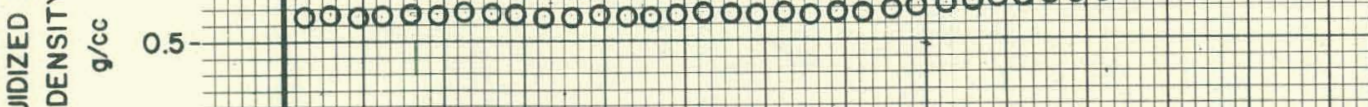

윽

$0-\pi$

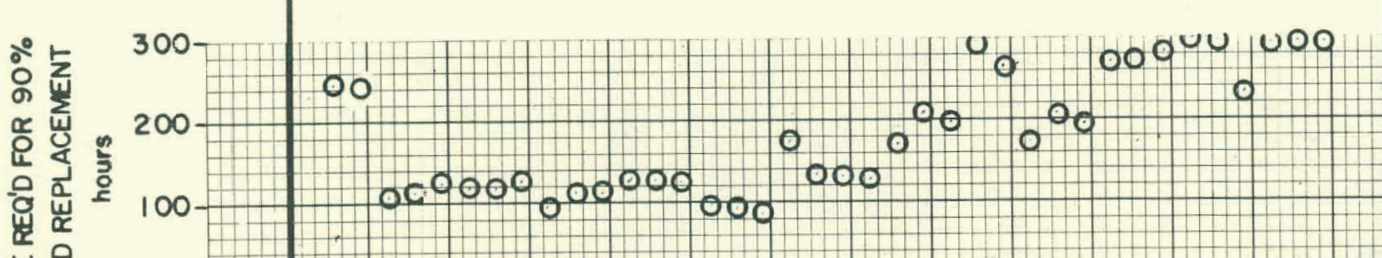

崖

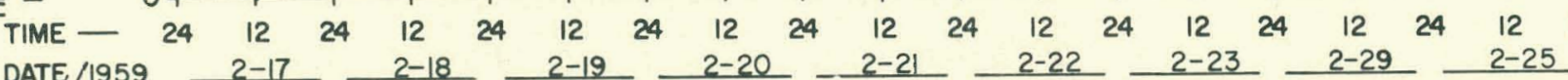

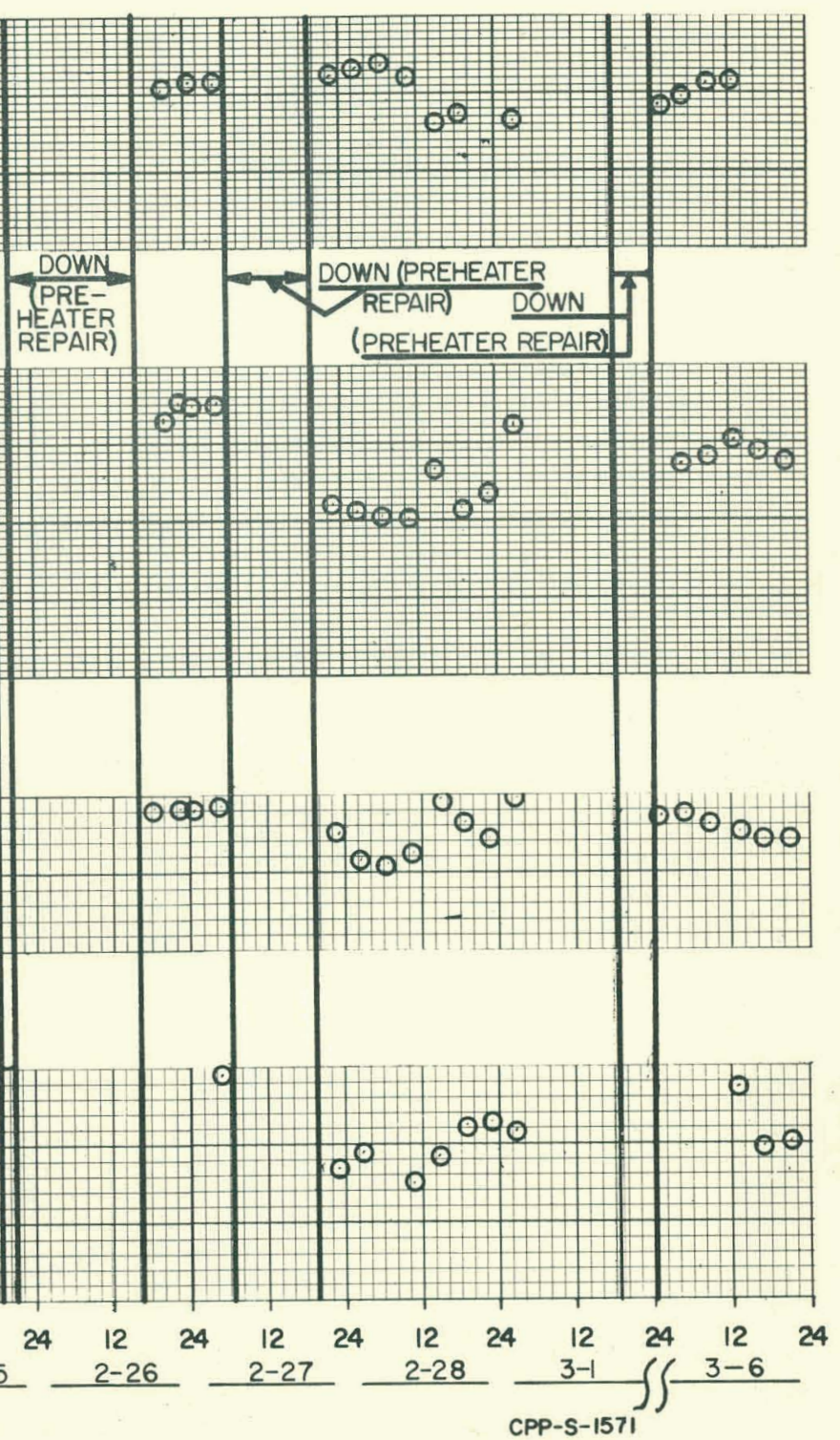

Fig. 14 Calciner Bed Data, Run 1 (Sheet 3 of 4 ) 
CALCINER $2 \mathrm{ft}$ RUN NO.

FEED RATE $40 \quad 1 / \mathrm{hr}$ BED TEMP. 500 드.
SUPERFICIAL FLUIDIZING VELOCITY $0.3 \rightarrow 0.64 \mathrm{ft} / \mathrm{sec}$

DRY FINES RETURN $11.3 \mathrm{scfm}$
EEED:-

$\mathrm{Al}\left(\mathrm{NO}_{3}\right)_{3}+1.25 \mathrm{M}$ $\mathrm{HNO}_{3}-1.25$ M
$\mathrm{NaNO}_{3} \mathrm{O} 0.089-\mathrm{M}$

$\mathrm{Hg}$ (NO3) 0.006 M

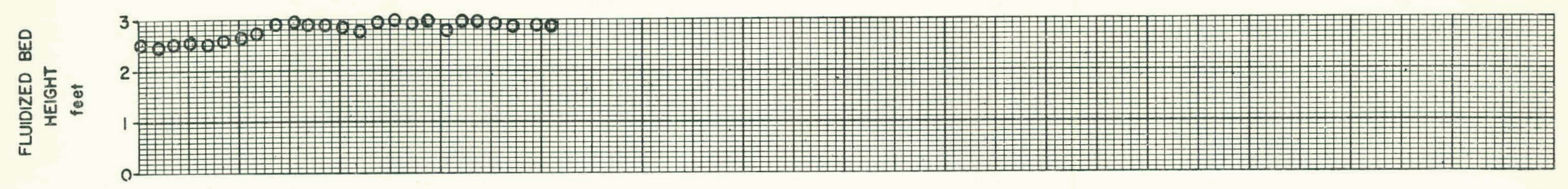

8
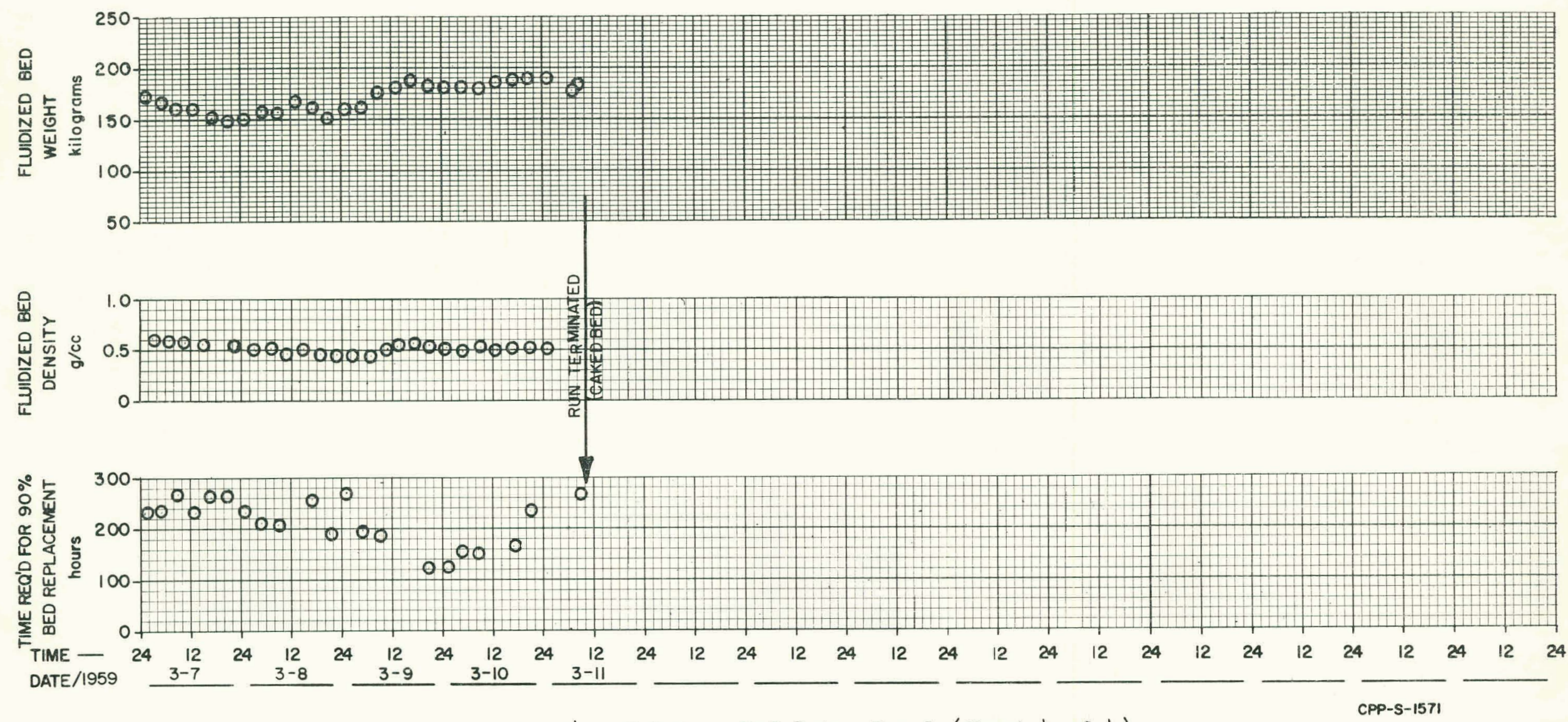

Fig. 14 Calciner Bed Data, Run 1 (Sheet 4 of 4) 


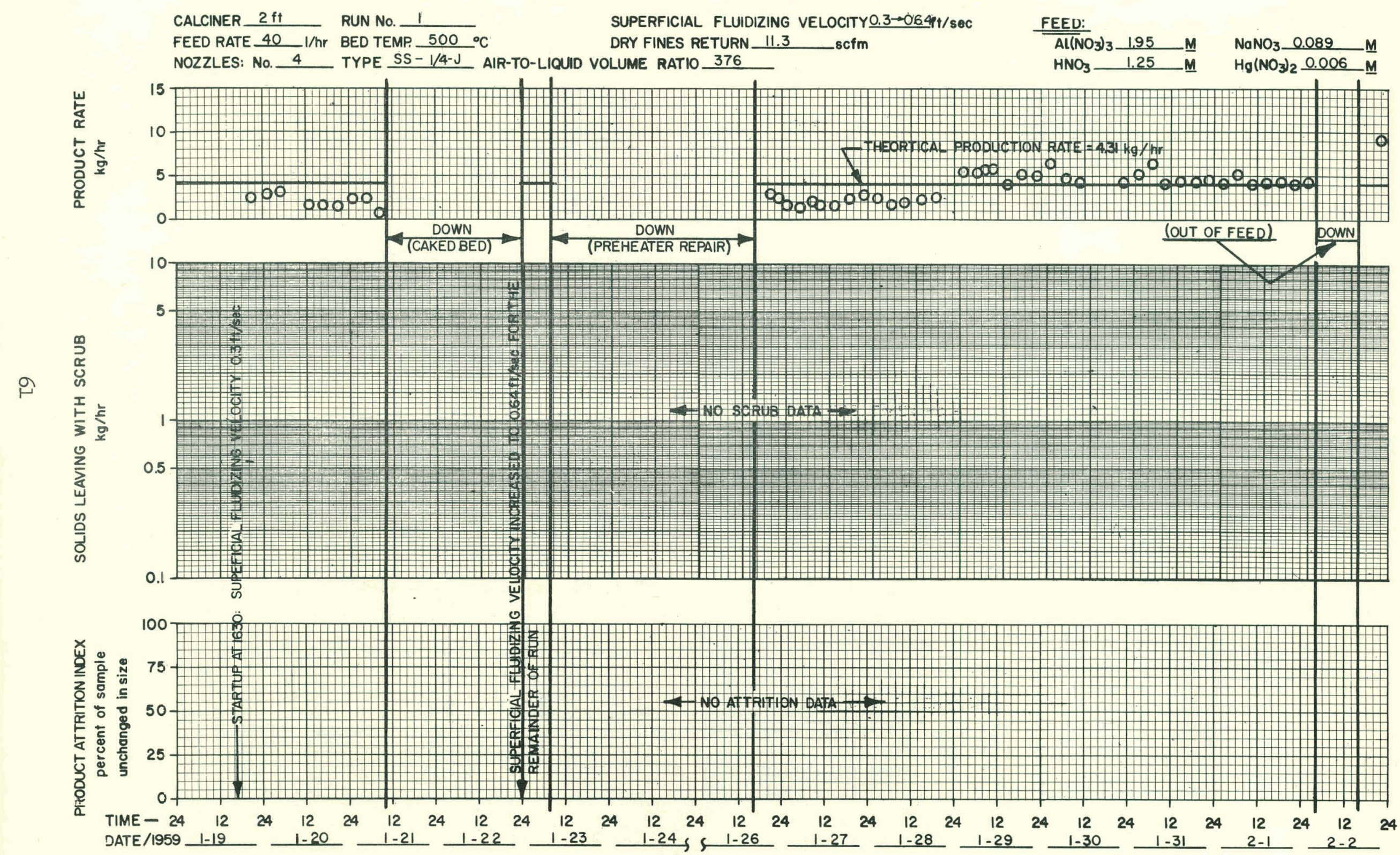

Fig. 15 General Data, Run 1 (Sheet 1 of 4) 
CALCINER 2 FT RUN No. 1

FEED RATE $40 \quad \mathrm{l} / \mathrm{hr}$ BED TEMP $500{ }^{\circ} \mathrm{C}$

NOZZLES: No. 4
SUPERFICIAL FLUIDIZING VELOCITY $0.3 \rightarrow 0.64 \mathrm{ft} / \mathrm{sec}$ DRY FINES RETURN 11.3 scfm

3

scfm
TYPE SS- $1 / 4 \mathrm{~J}$ AIR-TO-LIQUID VOLUME RATIO 376

FEED:

$\mathrm{Al}\left(\mathrm{NO}_{3}\right)_{3}+1.95$

$\mathrm{HNO}_{3}-1.25$
$\mathrm{NaNO}_{3}-0.089-\mathrm{M}$

$\mathrm{Hg}\left(\mathrm{NO}_{3}\right)_{2} \underline{0.006} \underline{\mathrm{M}}$
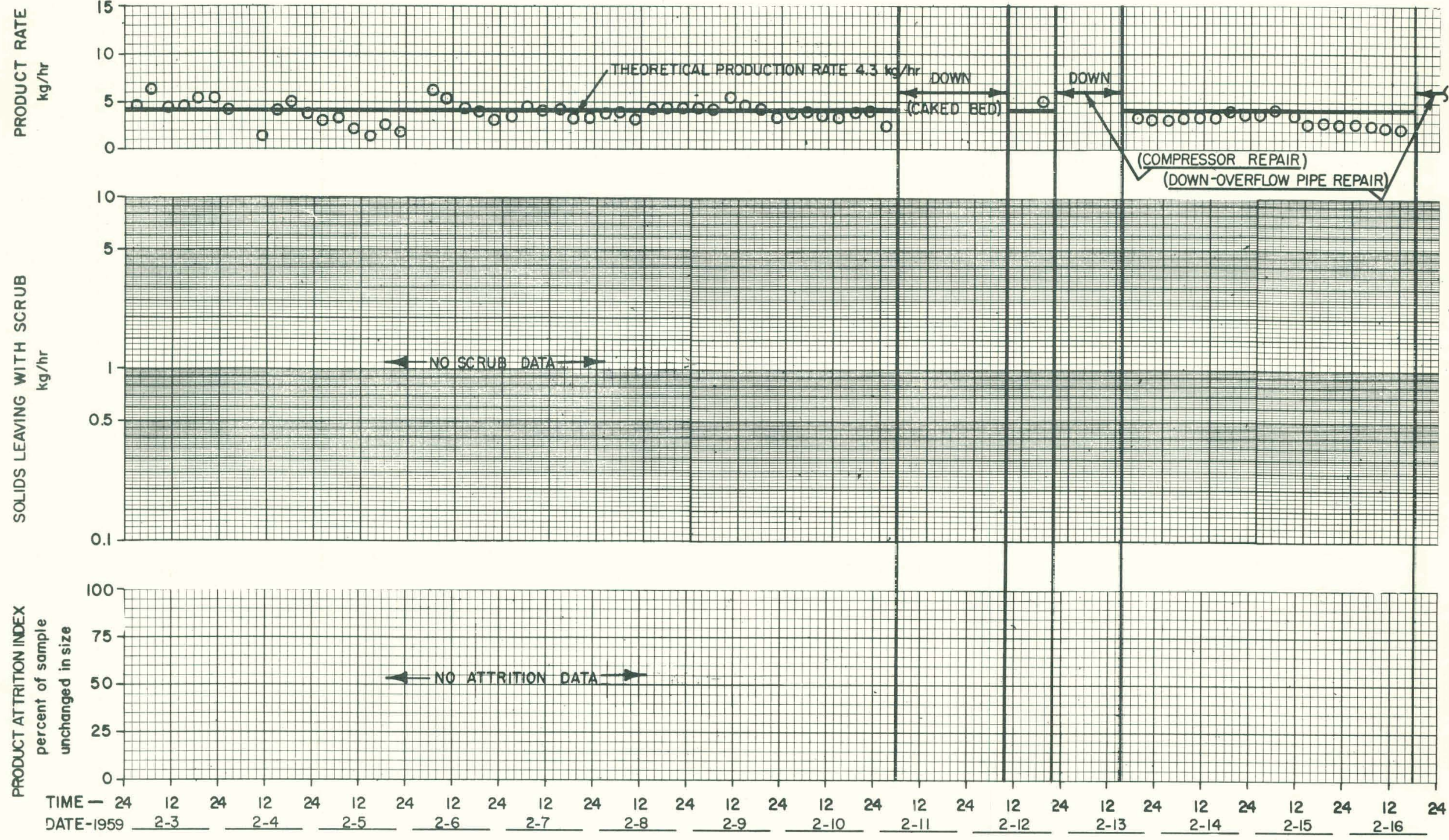

Fig. 15 General Data, Run 1 (Sheet 2 of 4)

CPP-S- 1573 
CALCINER 2 FT RUN No. 1

FEED RATE 40 I $/ \mathrm{hr}$ BED TEMP. $500{ }^{\circ} \mathrm{C}$

NOZZLES: No. 4 TYPE SS $1 / 4$
SUPERFICIAL FLUIDIZING VELOCITY $0.3 \rightarrow 0.64 \mathrm{f} t / \mathrm{sec}$

DRY FINES RETURN $11.3 \quad \mathrm{scfm}$
FEED:

$\mathrm{Al}\left(\mathrm{NO}_{3}\right)_{3} \quad 1.95-\mathrm{M} \quad \mathrm{NaNO}_{3} \quad 0.089$ M $\mathrm{HNO}_{3} \frac{1.25}{\mathrm{M}} \quad \mathrm{Hg}\left(\mathrm{NO}_{3}\right)_{2} 0.006 \mathrm{M}$
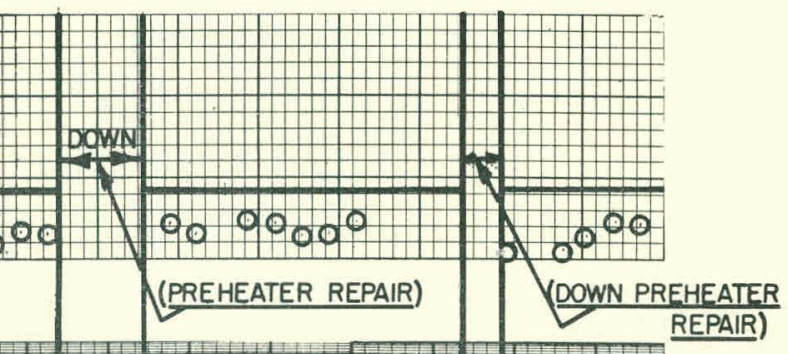

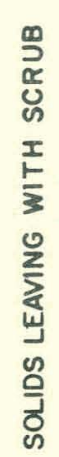

5

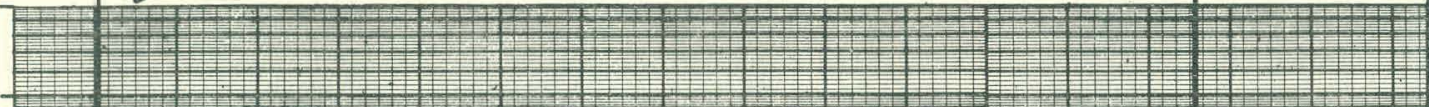
$0000000000000070000000000000000 \mid$ (OVERFLOW PIPE REPAIR)

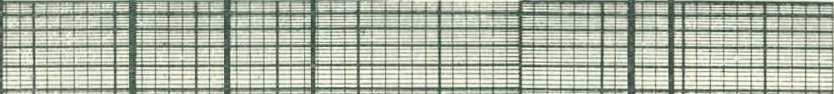
REPAIR)

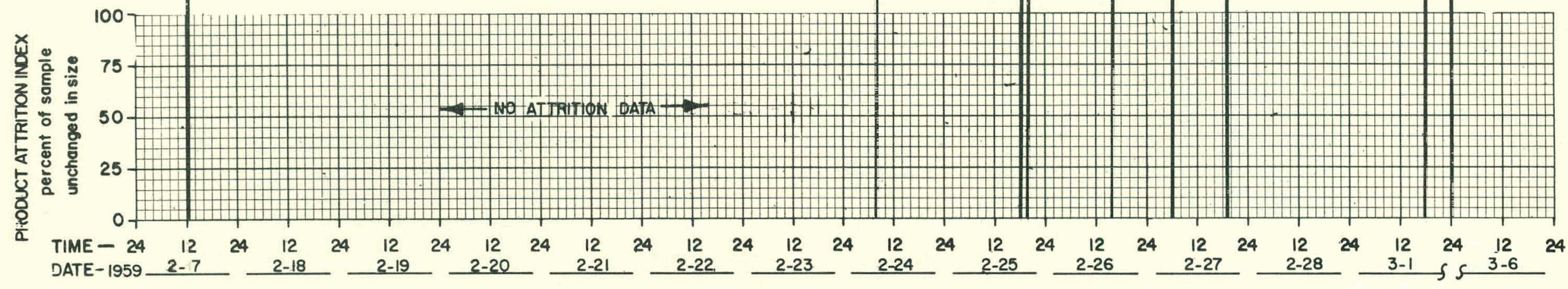

Fig. 15 General Data, Run 1 (Sheet 3 of 4) 
CALCINER $2 \mathrm{f \uparrow}$ RUN No.

FEED RATE $40 \quad 1 / \mathrm{hr}$ BED TEMP. $500^{\circ} \mathrm{C}$

NOZZLES: No. 4
SUPERFICIAL FLUIDIZING VELOCITY $0.3-3.64 \mathrm{ft} / \mathrm{sec}$

DRY FINES RETURN 11.3
FEED:

$A l\left(N O_{3}\right) 3 \frac{1.95}{1.95}$
$\mathrm{NaNO}_{3} 0.089$

$\mathrm{Ho}\left(\mathrm{NO}_{3}\right)_{2} 0.006-\mathrm{M}$
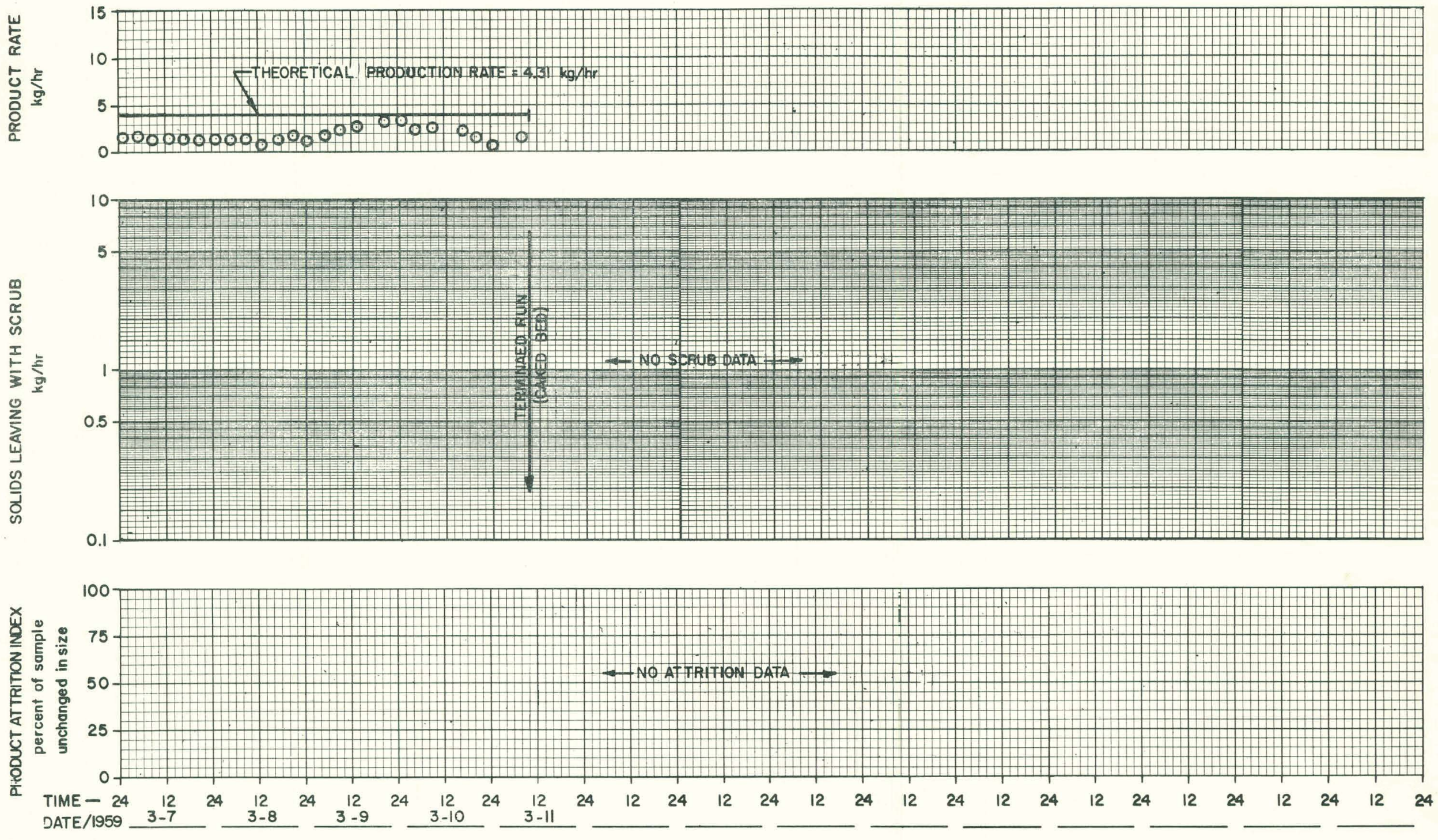

Fig. 15 General Data, Run 1 (Sheet 4 of 4) 
$\underline{\text { Run } 2}$

Period Covered: From March 13, 1959 to March 30, 1959

Objective: This was the second mun of a statistical program designed to relate the product and off-gas characteristics with the calciner operating conditions. Another objective was to continue equipment development and evaluation.

Equipment: The equipment used for this run was the same as that used in Run 1 .

Cumulative NaK Heating System Operating Data: (including this run)

55 start-ups; 1377 hours above $1000^{\circ} \mathrm{F} ; 457$ hours below $1000^{\circ} \mathrm{F}$.

\section{Run Conditions:}

Bed temperature, ${ }^{\circ} \mathrm{C} \quad 500$

Feed rate, I/hr 40

Nozzlc air-to-liquid volume ratio 244

Number of Spraying Systems Company Type 1/4 J nozzles 4

Total nozzle air rate, scf'm

Superficial fluidizing velocity, ft/sec

Initial

0.78

Changed on March 25 to

0.90

Feed Composition: Aluminum nitrate, $\underline{M} \quad 1.95$

Nitric acid, $\quad \overline{\mathrm{M}} \quad 1.25$

Sodium nitrate, $\bar{M} \quad 0.089$

Mercuric nitrate, $\underline{\bar{M}} \quad 0.006$

Results: No results were obtained which were significant to the statistical program because steady-state operation was not achieved. Additional operating experience was obtained and the equipment was evaluated further.

Difficulties: The oil-fired fluidizing air preheater gave trouble throughout the run. It was difficult to determine and hold the proper oil-to-air ratio. One of the feed rate controllers failed to control throughout most of the run. 
CALCINER 2-FT RUN NO. 2

FEED RATE $40 \mathrm{l} / \mathrm{hr}$. BED TEMP. $500{ }^{\circ} \mathrm{C}$

NOZZLES: No. 4
SUPERFICIAL FLUIDIZING VELOCITY $0.78-0.9 \mathrm{ft} / \mathrm{sec}$.

DRY FINES RETURN 14.3 scfm

AIR-TO-LIQUID VOLUME RATIO 244
FEED:

$\mathrm{Al}\left(\mathrm{NO}_{3}\right)_{3} 1.95$

$\mathrm{HNO}_{3} 1.25$
$\mathrm{NaNO}_{3} 0.089$

$\mathrm{Hg}\left(\mathrm{NO}_{3}\right)_{2}$ ㅇ․이 $\mathrm{M}$

竧.

$\frac{\omega}{\frac{5}{5}}$

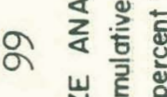

\begin{tabular}{|l|l|l|l|l|l|l|l|}
\hline & & & & \\
\hline
\end{tabular}

\begin{tabular}{|c|c|c|c|}
\hline & & \\
\hline
\end{tabular}

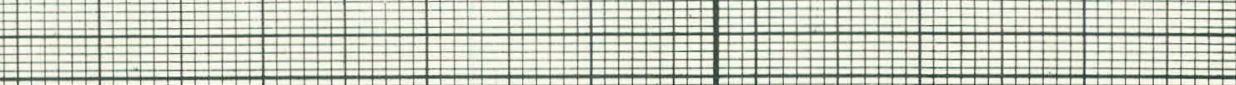

$00 \longrightarrow 20$ Tyler Mesh $+2+1$

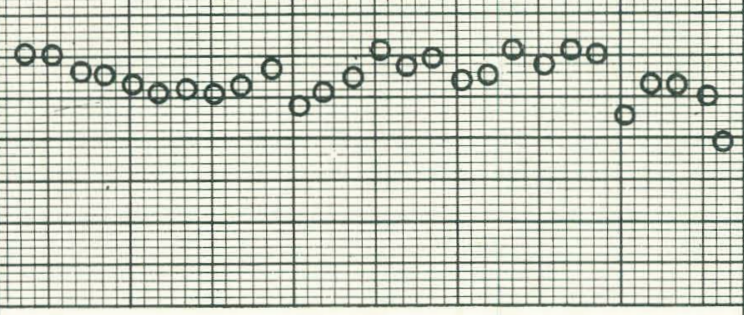

$00^{0000000}$

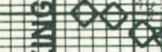

60
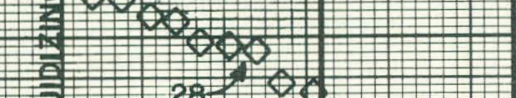

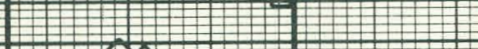

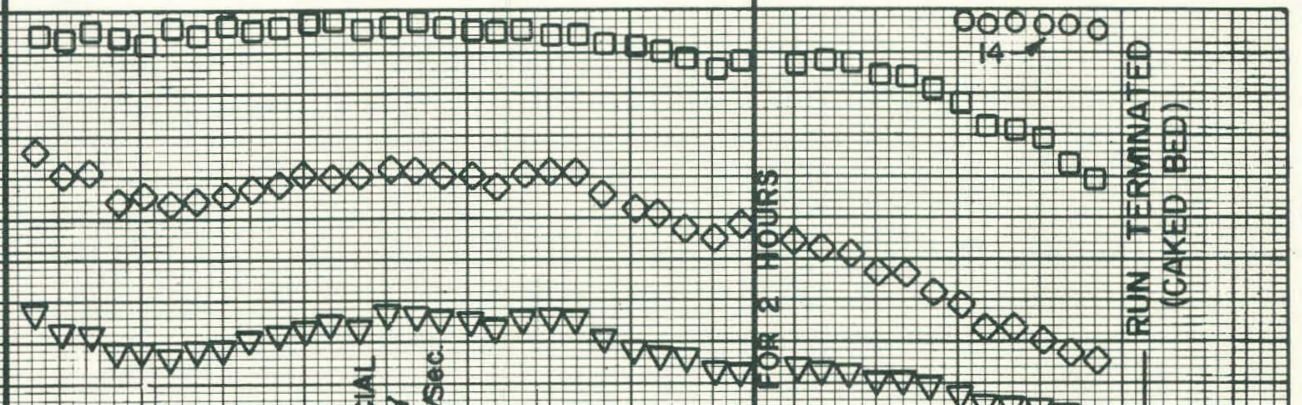

20

\begin{tabular}{r|r|r|r|}
\hline+4 \\
\hline
\end{tabular}

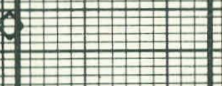

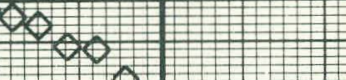

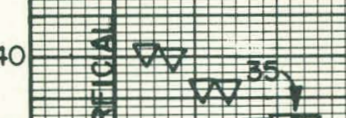

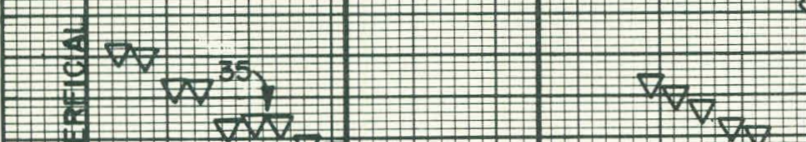

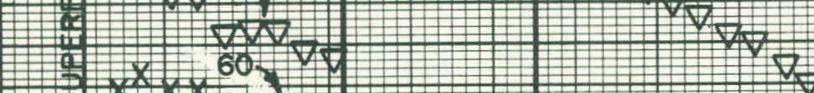

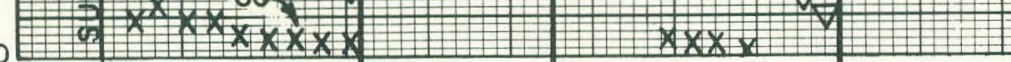

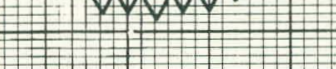

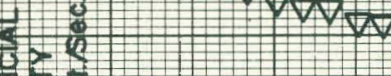

$\forall \rightarrow-1+2$

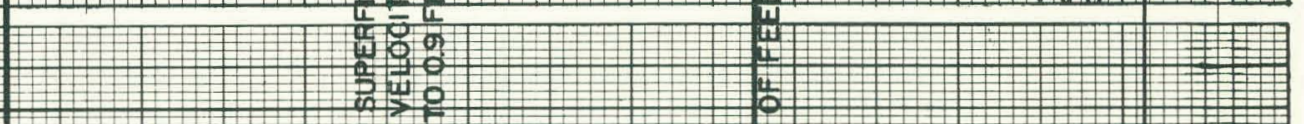

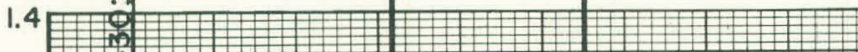

$0 . 8 \longdiv { 1 + 4 }$

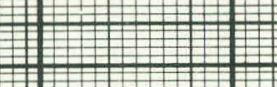

0.6 (

$0.6 \div$

0.4 0000000

0.2

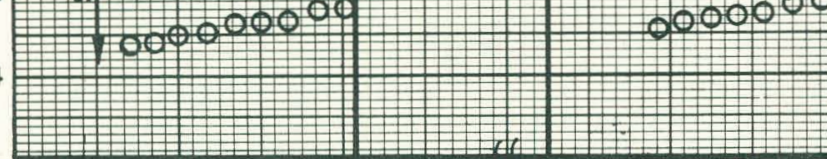

$\begin{array}{lllllllllllll}\text { TIME }-24 & 12 & 24 & 12 & 24 & 12 & 24 & 12 & 24 & 12 & 24 & 12\end{array}$

DATE $/ 1959-3-13-3-14-3-15$ J 5

$$
\text { Fig. } 16 \text { Product Data, Run } 2
$$

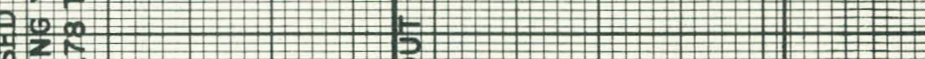
Q 4. $=$ $2 \frac{1}{2}$

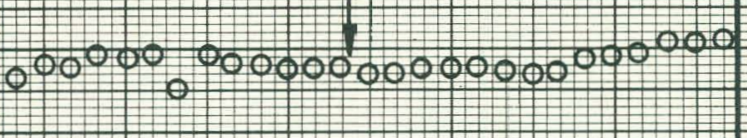
$+1000000$ $00000000 .+$ $\begin{array}{r}\hline \\ \hline\end{array}$

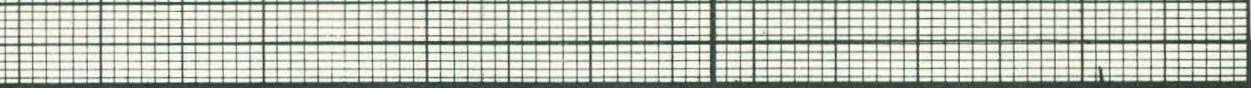
$\begin{array}{llllllllllllllll}12 & 24 & 12 & 24 & 12 & 24 & 12 & 24 & 12 & 24 & 12 & 24 & 12 & 24 & 12 & 24\end{array}$ 
CALCINER 2-Ft. RUN No. 2

FEED RATE 40 l'hr BED TEMP $500{ }^{\circ} \mathrm{C}$

NOZZLES: No. 4
SUPERFICIAL FLUIDIZING VELOCITY $0.78-0.9 \% 1 / \mathrm{sec}$

DRY FINES RETURN 14.3 scfm
FEED:

$\mathrm{Al}\left(\mathrm{NO}_{3}\right)_{3} 1.95 \mathrm{M}$

$\mathrm{NaNO}_{3} \mathrm{O} .089$

$\mathrm{Hg}\left(\mathrm{NO}_{3}\right)_{2} 0.006 \frac{\mathrm{M}}{\mathrm{M}}$

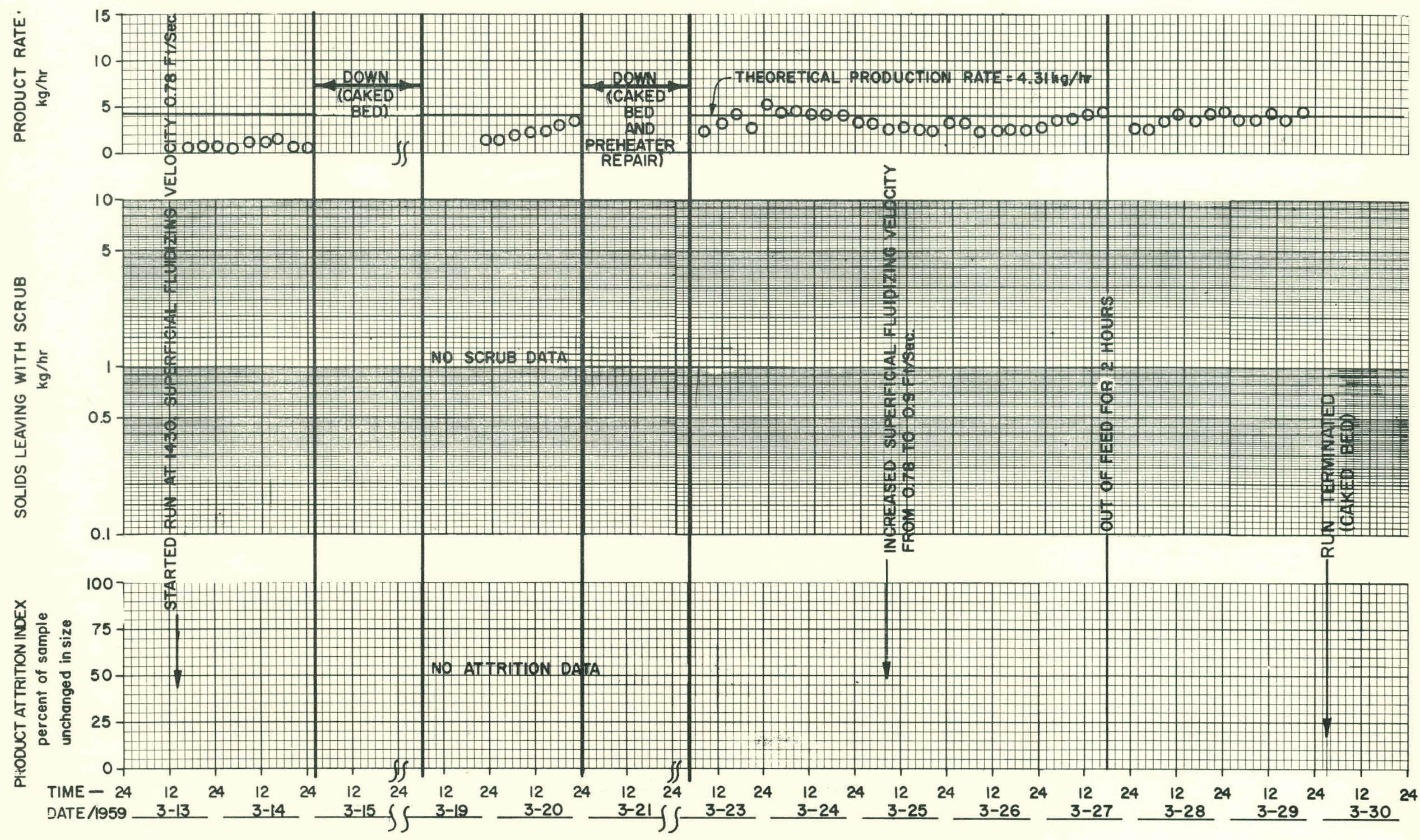

Fig. 17 General Data, Run 2

CPP-S-1573 
$\underline{\text { Run } 3}$

Period Covered: From March 30, 1959 to April 12, 1959

Objective: The statistical program was revised so that the calciner could be operated under more favorable conditions, as many of the operating variables called for in the initial program were found to be in an inoperable range. This was the first run made under the new statistical program. Another objective was the continuation of equipment development and evaluation.

Equipment: The equipment used for this run was the same as that used in Run 1 .

Cumulative NaK Hcating Syctem Operating Data (incluning this run):

56 start-ups; 1654 hours above $1000^{\circ} \mathrm{F} ; 479$ hours below $1000^{\circ} \mathrm{F}$.

Run Conditions:

Bed. temperature, ${ }^{\circ} \mathrm{C} \quad 500$

Feed rate, I/hr 40

Nozzle air-to-liquid volume ratio 412

Number of Spraying Systems Company Type 1/4 J nozzles 4

Total nozzle air rate, scfm 12

Superficial fluidizing velocity, ft/sec 0.52

Feed Composition: Aluminum nitrate, $\underline{M} \quad 1.95$

Nitric acid, $\overline{\mathrm{M}} \quad 1.25$

Sodium nitrate, $\bar{M} \quad 0.089$

Mercuric nitrate, $\bar{M} \quad 0.006$

Results: Results significant to the reviscd statistical

program were not obtained during this run because of

failure to achieve steady-state operation.

Difficulties: The connecting leads to the electromagnetic pump burmed out and were replaccd with heavier unes. The oil-fired fluidizing air burner failed when a spark plug broke. 
GALCINER 2-FT. RUN No. 3

FEED RATE $40 \mathrm{l} / \mathrm{hr}$. BED TEMP. $500{ }^{\circ} \mathrm{C}$

NOZZLES: No. 4 TYPE SS-1/4J AIR-1
SUPERFICIAL FLUIDIZING VELOCITY 0.523

DRY FINES RETURN 13.9 scfm

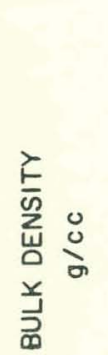

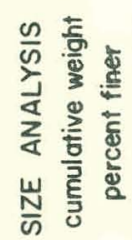

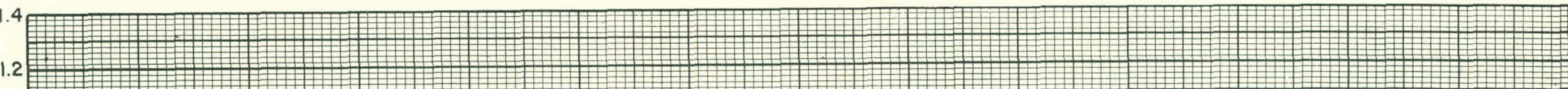

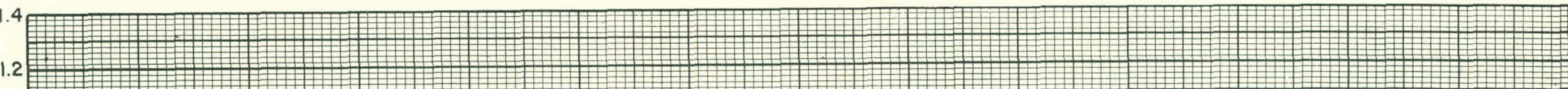

FEED:

$A l\left(\mathrm{NO}_{3}\right) 3+1.95-\mathrm{M}$

$\mathrm{HNO}_{3}-1.25-\mathrm{M}$
$\mathrm{NaNO} 3 \stackrel{0.089}{\mathrm{M}}$

$\mathrm{Hg}\left(\mathrm{NO}_{3}\right)_{2} \mathrm{e} .006 \mathrm{M}$

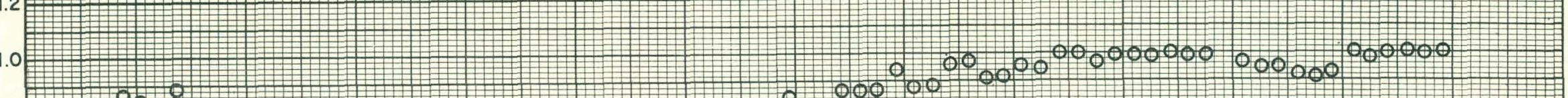

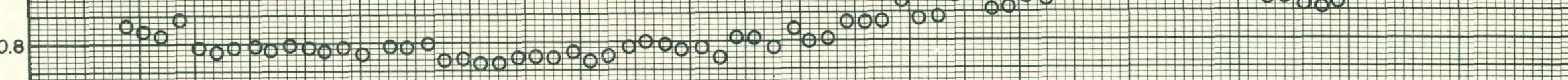

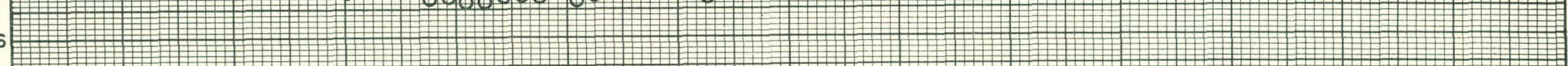

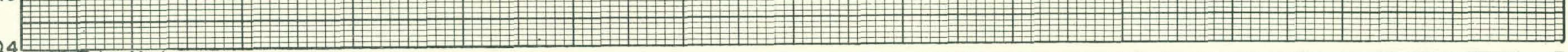

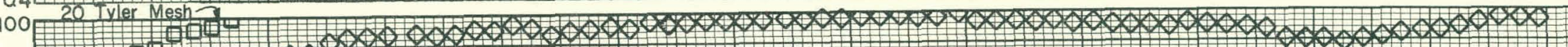

(1)

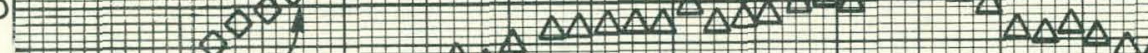

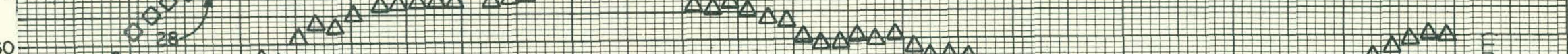

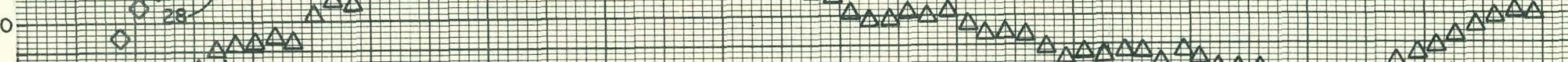

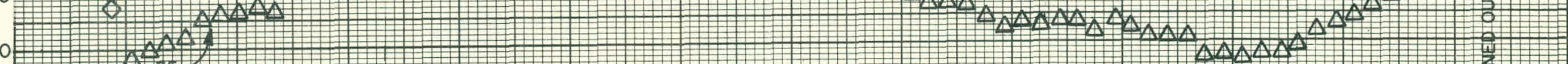

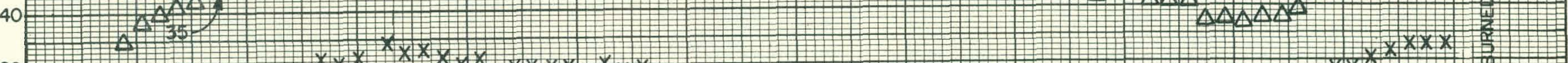

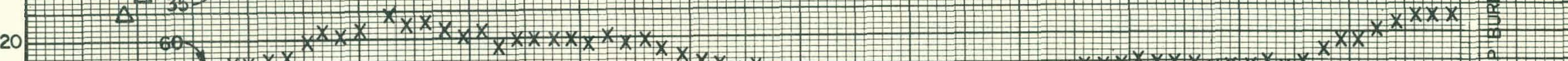

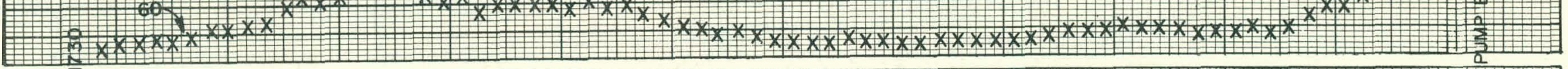

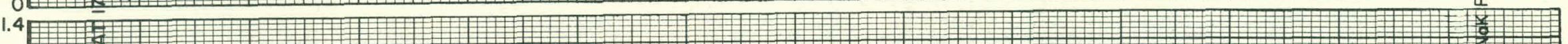
\begin{tabular}{c|c|c|c|}
\hline &
\end{tabular}

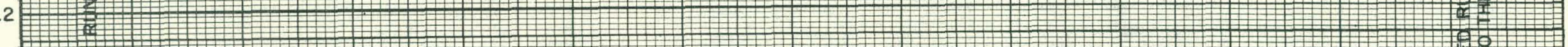

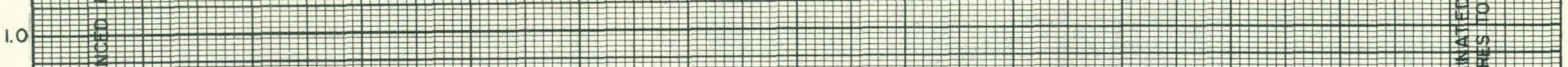

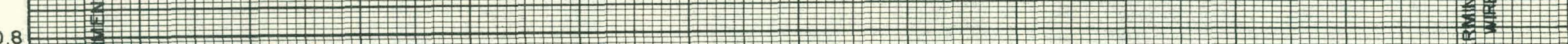

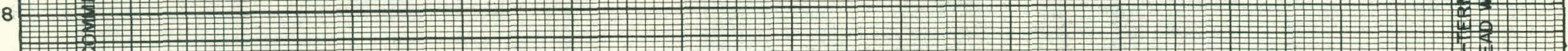

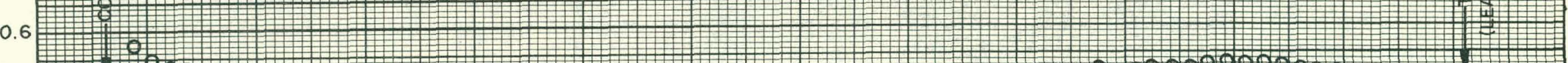

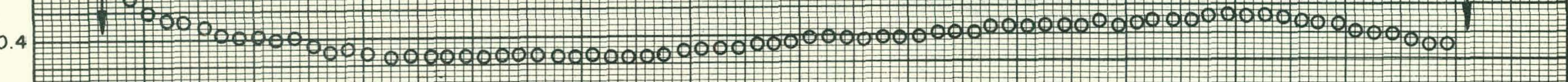

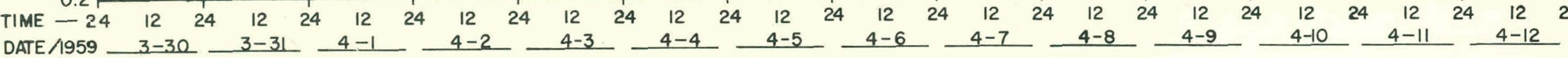
$\longrightarrow$ CPP-S-1570 
$\underline{\operatorname{Run} 4}$

Period Covered: From May 22, 1959 to July 5, 1959

Objective: This was the second run made under the revised statistical program. The objectives of this remained the same as those for previous runs, i.e., to obtain steadystate data to relate the calciner product and off-gas characteristics with the operating conditions and to continue equipment evaluation and testing.

Equipment: The equipment used during this run was the same as that used in Run 1, except that the oil-fired fluidizing air preheater was removed and the fluidizing air was heated by passing it through a heat exchanger placed in the top of the NaK furnace.

Cumulative NaK Heating System Operating Data (including this run): 66 start-ups; 2245 hours above $1000^{\circ} \mathrm{F}$; 545 hours below $1000^{\circ} \mathrm{F}$. Run Conditions:

Bed temperature, ${ }^{\circ} \mathrm{C}$

Feed rate, $1 / \mathrm{hr}$

Nozzle air-to-liquid volume ratio

Total nozzle air rate, scfm

Superficial fluidizing velocity, ft/sec

Initial

Changed on June 5 to

Feed Composition: Aluminum nitrate, M 1.95

Nitric acid, $\overline{\mathrm{M}} \quad 1.25$

Sodium nitrate, $\overline{\bar{M}} \quad 0.089$

Mercuric nitrate, $\underline{\bar{M}} \quad 0.006$

Results: Results significant to the statistical program were not obtained because steady-state operation was not achieved during this run.

Difficulties: The major source of trouble during this run was the feed rate control system. The dry fines returm system also plugged and became inoperative. 
CALCINER 2-FT RUN No. 4

FEED RATE $40 \mathrm{l} / \mathrm{hr}$. BED TEMP $500^{\circ} \mathrm{C}$

DRY FINES RETURN $14.9-13.2 \mathrm{scfm}$

$.85 \rightarrow 1.04 \mathrm{ft} / \mathrm{sec}$

NOZZLES: No. 4 TYPE SS-1/4 J AIR-TO-LIQUID VOLUME RATIO 306
FEED:

$\mathrm{Al}\left(\mathrm{NO}_{3}\right)_{3}, 1.95-\mathrm{M}$

$\mathrm{HNO}_{3}-1.25$
NaNO3 0.089

$\mathrm{Hg}\left(\mathrm{NC}_{3}\right)_{2} \underline{0.006} \underline{\mathrm{M}}$

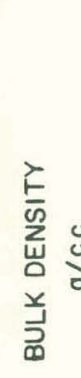

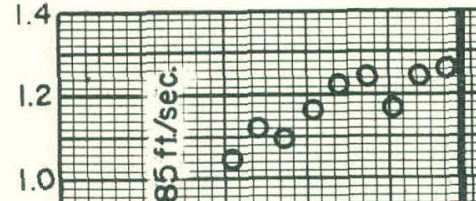
000.00

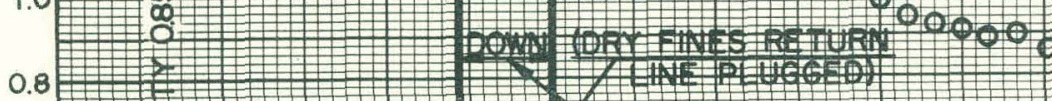

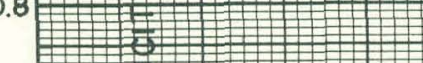

06

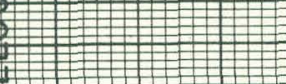

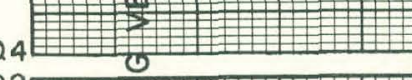

$1 0 0 \longdiv { 2 \quad 0 0 0 0 0 0 0 0 }$

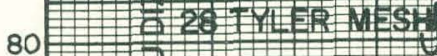

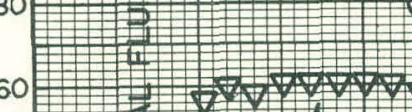

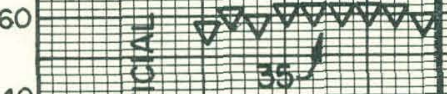

$4 0 \longdiv { - 1 + 4 }$

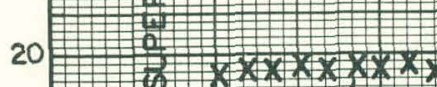

-

$1.4 \quad$ -

啚

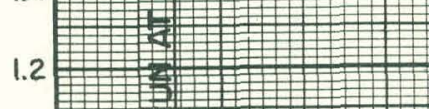

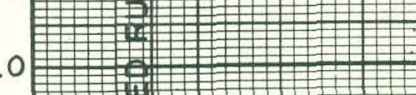

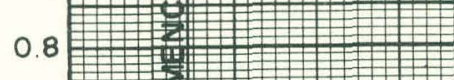

0.6

2

$\overbrace{}^{\infty}$

$0.2+0000000$

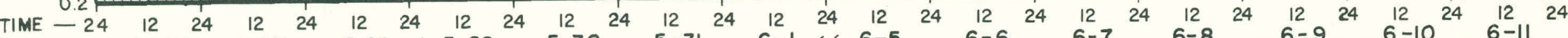

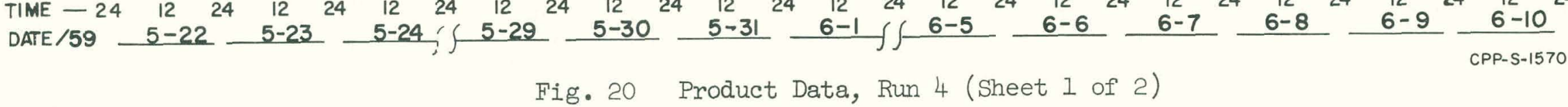

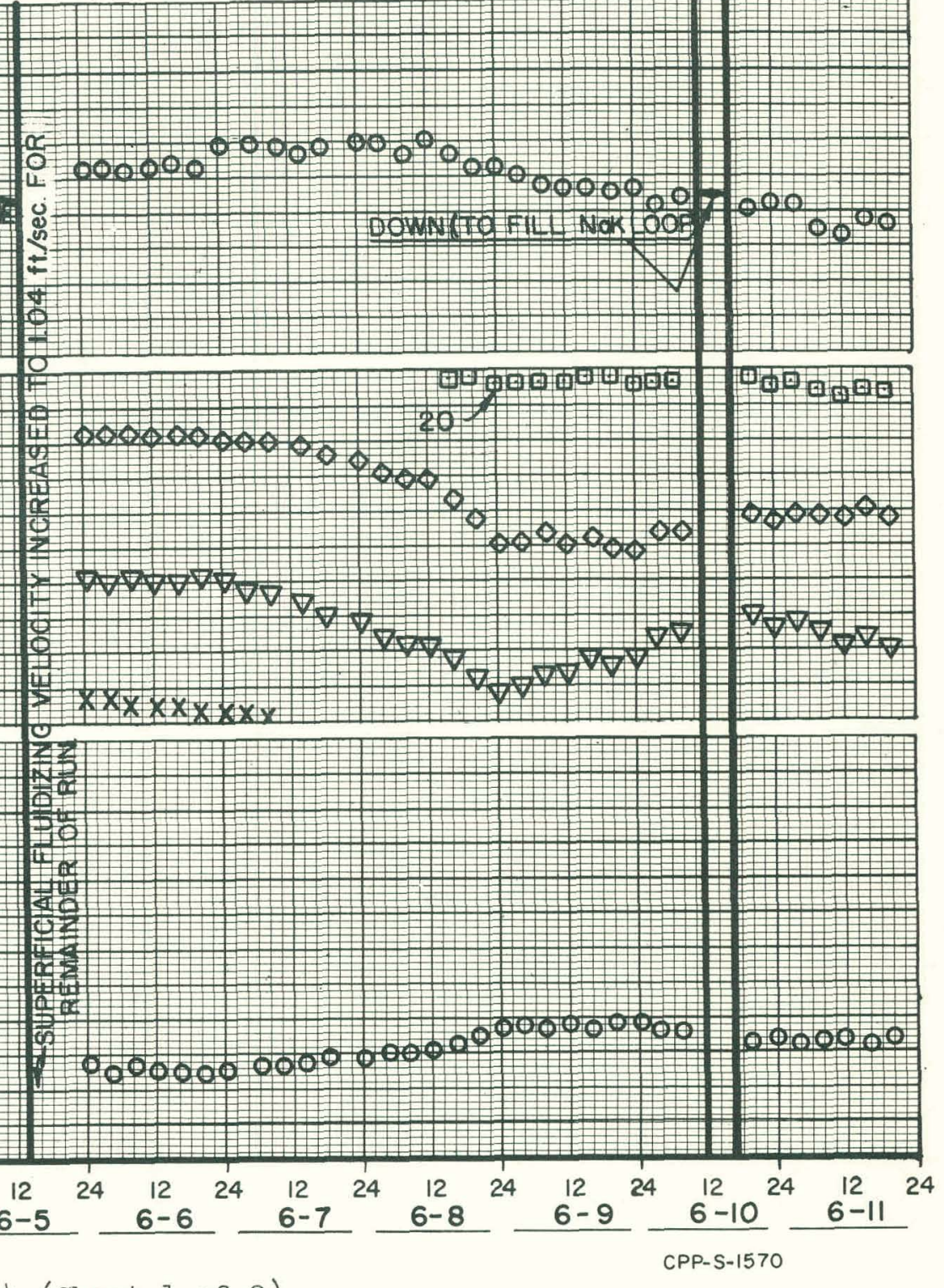


CALCINER 2-FT RUN No. 4

FEED RATE $40 \mathrm{l} / \mathrm{hr}$. BED TEMP. $500{ }^{\circ} \mathrm{C}$

NOZZLES: NO. 4
SUPERFICIAL FLUIDIZING VELOCITY $0.85-1.04$ f $\mathrm{ft} / \mathrm{sec}$.

DRY FINES RETURN $14.9 \rightarrow 13.2 \mathrm{scfm}$
FEED:

$\mathrm{Al}\left(\mathrm{NO}_{3}\right) 3 \frac{1.95}{1.25}$

$\mathrm{HNO}_{3} 1.25$
NaNO3 $0.089 \mathrm{M}$

$\mathrm{Hg}\left(\mathrm{NO}_{3}\right)_{2}$ O.006 M

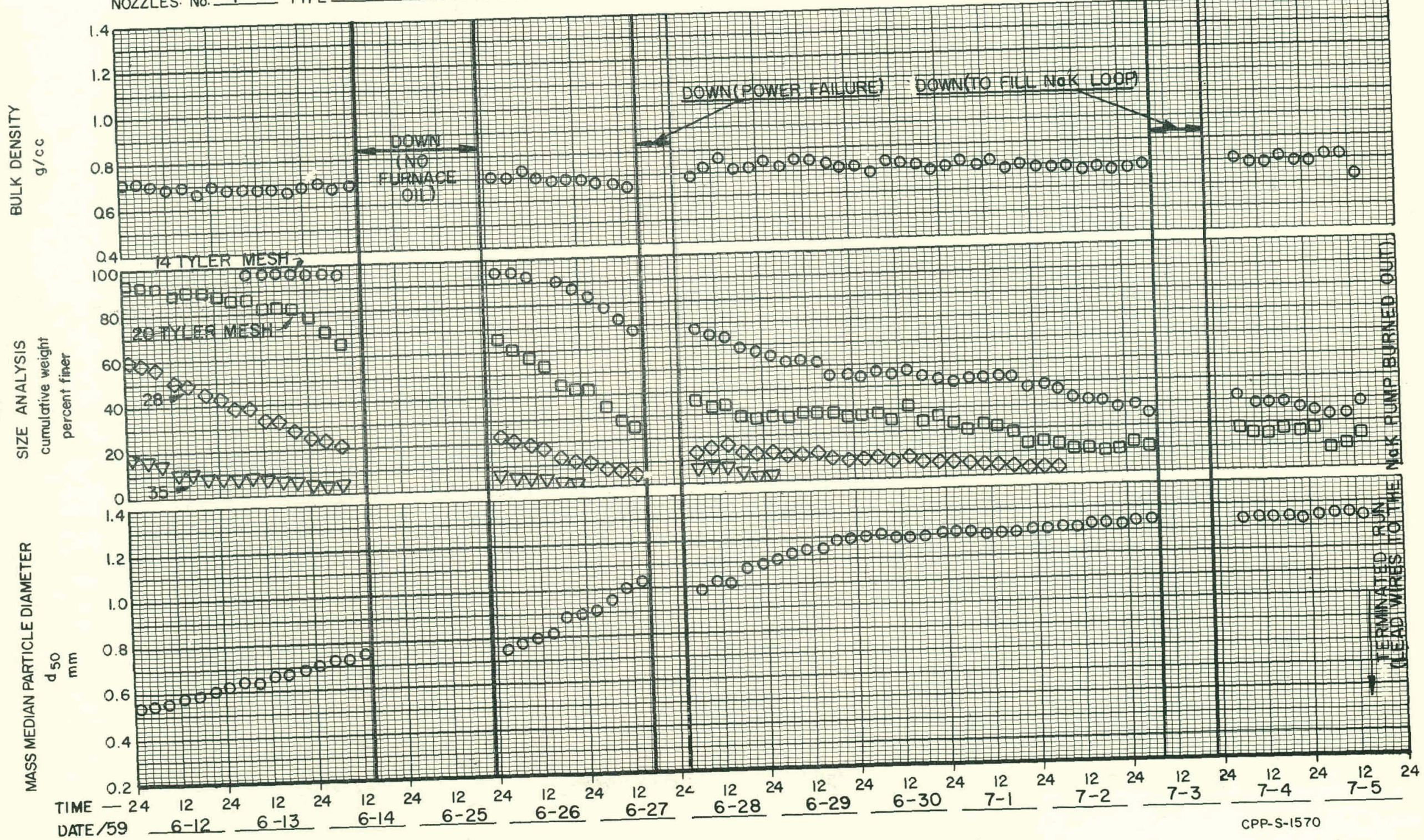

Fig. 20 Product Data, Run 4 (Sheet 2 of 2) 
CALCINER 2 - FT. RUN No. 4

FEED RATE $40 \mathrm{I} / \mathrm{hr}$ BED TEMP. $500{ }^{\circ} \mathrm{C}$

SUPERFICLAL FLUIDIZING VELOCITY $0.85-1.04 \mathrm{ft} / \mathrm{sec}$ DRY FINES RETURN $14.9-13.2$ scim
FEED:

$\mathrm{Al}\left(\mathrm{NO}_{3}\right)_{3} \frac{1.95}{\mathrm{M}}$

$\mathrm{HNO}_{3}-\frac{1.25}{\mathrm{M}}$
$\mathrm{NaNO}_{3} 0.089$

$\mathrm{Hg}\left(\mathrm{NO}_{3}\right)_{2} \mathrm{O} .006$

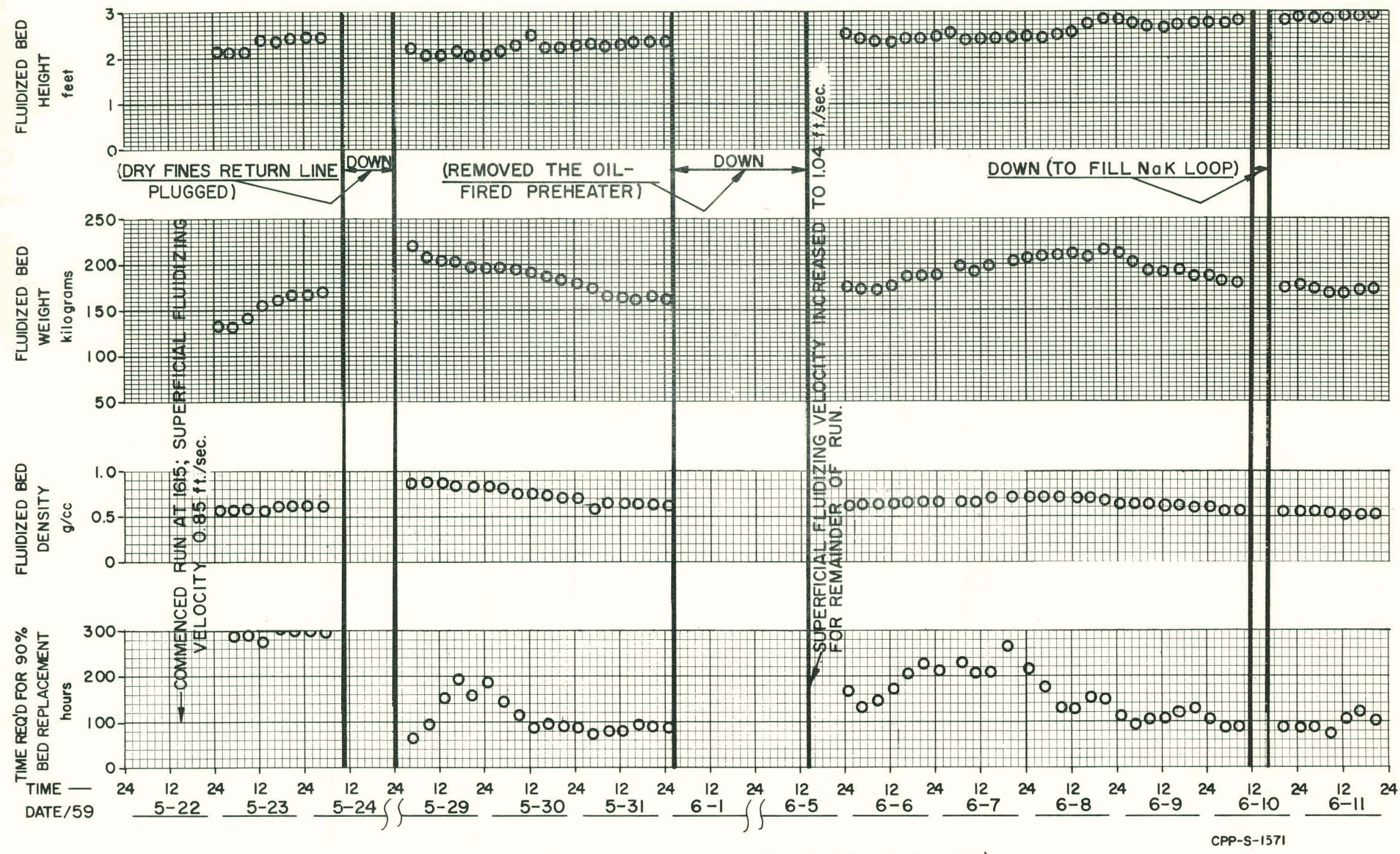

Fig. 21 Calciner Bed Data, Run 4 (Sheet 1 of 2) 
CALCINER 2-FT. RUN No. 4

FEED RATE $40 \mathrm{l} / \mathrm{hr}$ BED TEMP. $500{ }^{\circ} \mathrm{C}$

SUPERFICIAL FLUIDIZING VELOCITY $0.85-1.04 \mathrm{ft} / \mathrm{sec}$ DRY FINES RETURN $14.9-13.2 \mathrm{scfm}$

NOZZLES: NO. 4 TYPE SS-I/4 J AIR-TO-LIQUID VOLUME RATIO 306
FEED:

$\mathrm{Al}\left(\mathrm{NO}_{3}\right)_{3} \quad 1.95 \mathrm{M} \quad \mathrm{NaNO}_{3} \mathrm{O} .089$

$\mathrm{HNO}_{3} \mathrm{I} .25 \mathrm{M} \quad \mathrm{Hg}\left(\mathrm{NO}_{3}\right)_{2} \underline{0.006} \underline{M}$
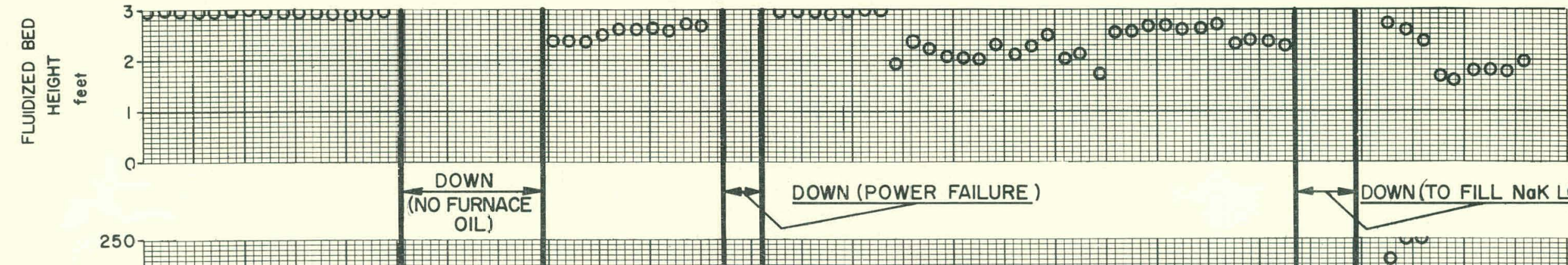

봉

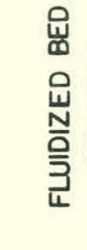


CALCINER_2 - FT RUN No. 4

FEED RATE $401 / \mathrm{hr}$ BED TEMP $500^{\circ} \mathrm{C}$
SUPERFICIAL FLUIDIZING VELOCITY0.85-104t//sec

DRY FINES RETURN $14.9 \rightarrow 13.2 \mathrm{scfm}$
FEED:

$\left.\left.\mathrm{Al}_{(\mathrm{NO}}\right)_{3}\right)_{3} \frac{1.95}{1.25} \mathrm{NaNO}_{3} \mathrm{O} 0.089 \mathrm{M}$

$\mathrm{HNO}_{3} \frac{1.25}{\mathrm{M}} \quad \mathrm{Hg}\left(\mathrm{NO}_{3}\right)_{2} \underline{0.006} \underline{M}$

$\frac{w}{a}$

论 导

: TYPE SS-1/4 J AIR-TO-LIQUID VOLUME RATIO 306
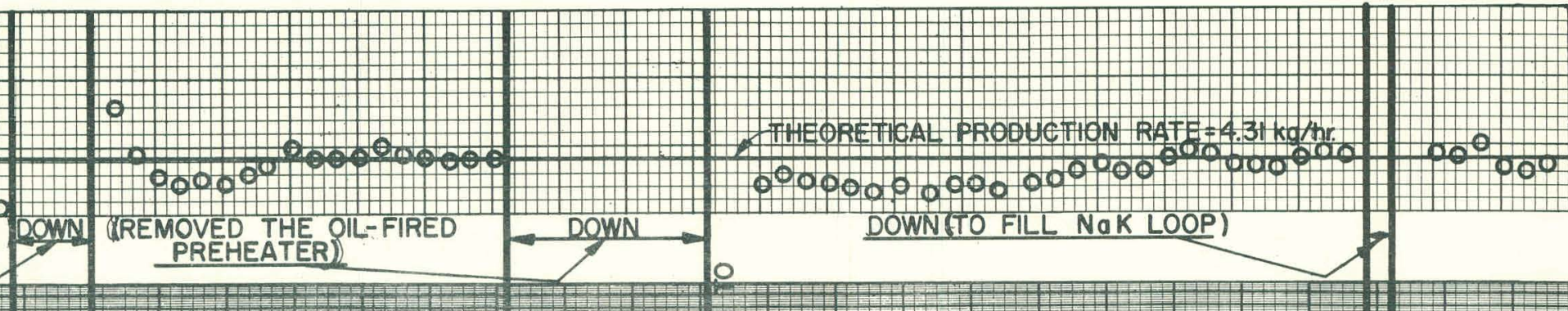

0 IDRY FINES RET RURN IN PLUGGED)

5

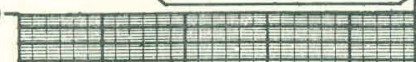
PREHEATER

品

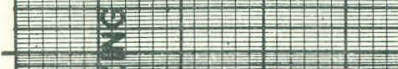

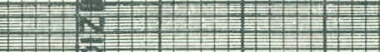

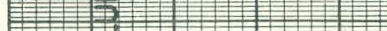

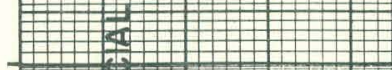

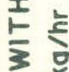

ब

山્ય
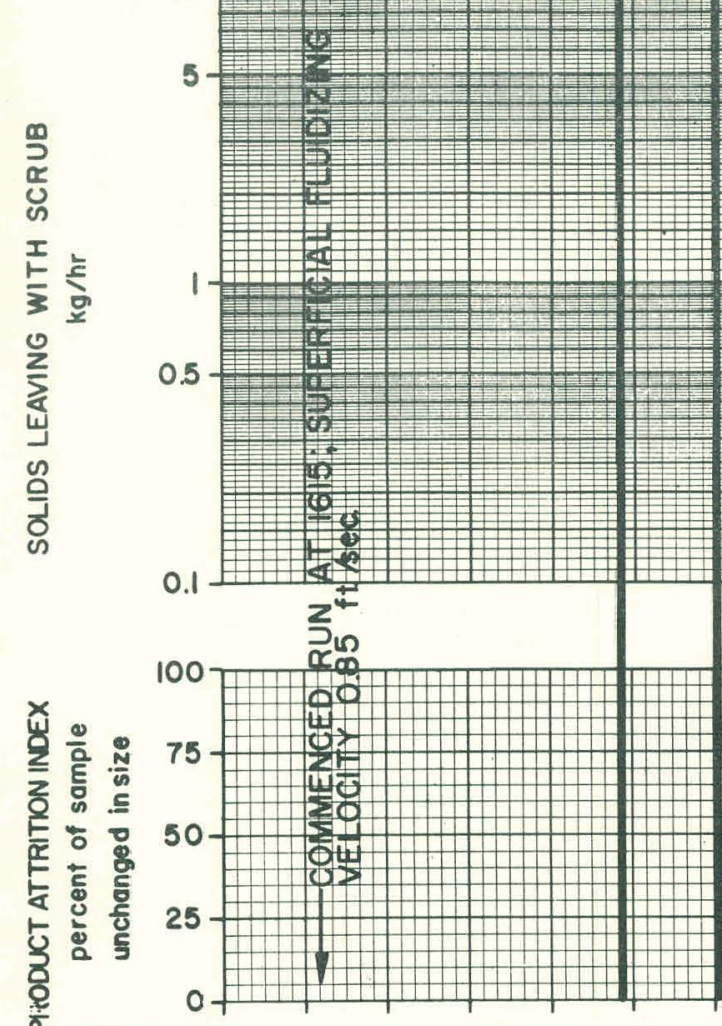

+

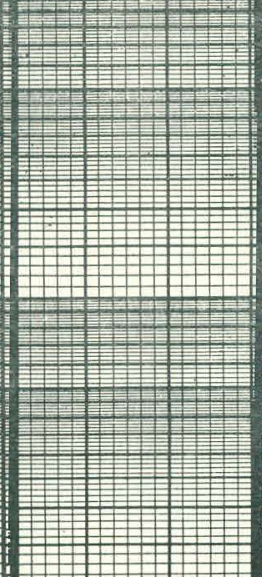

DOWNTO FLL NAK LOOP)
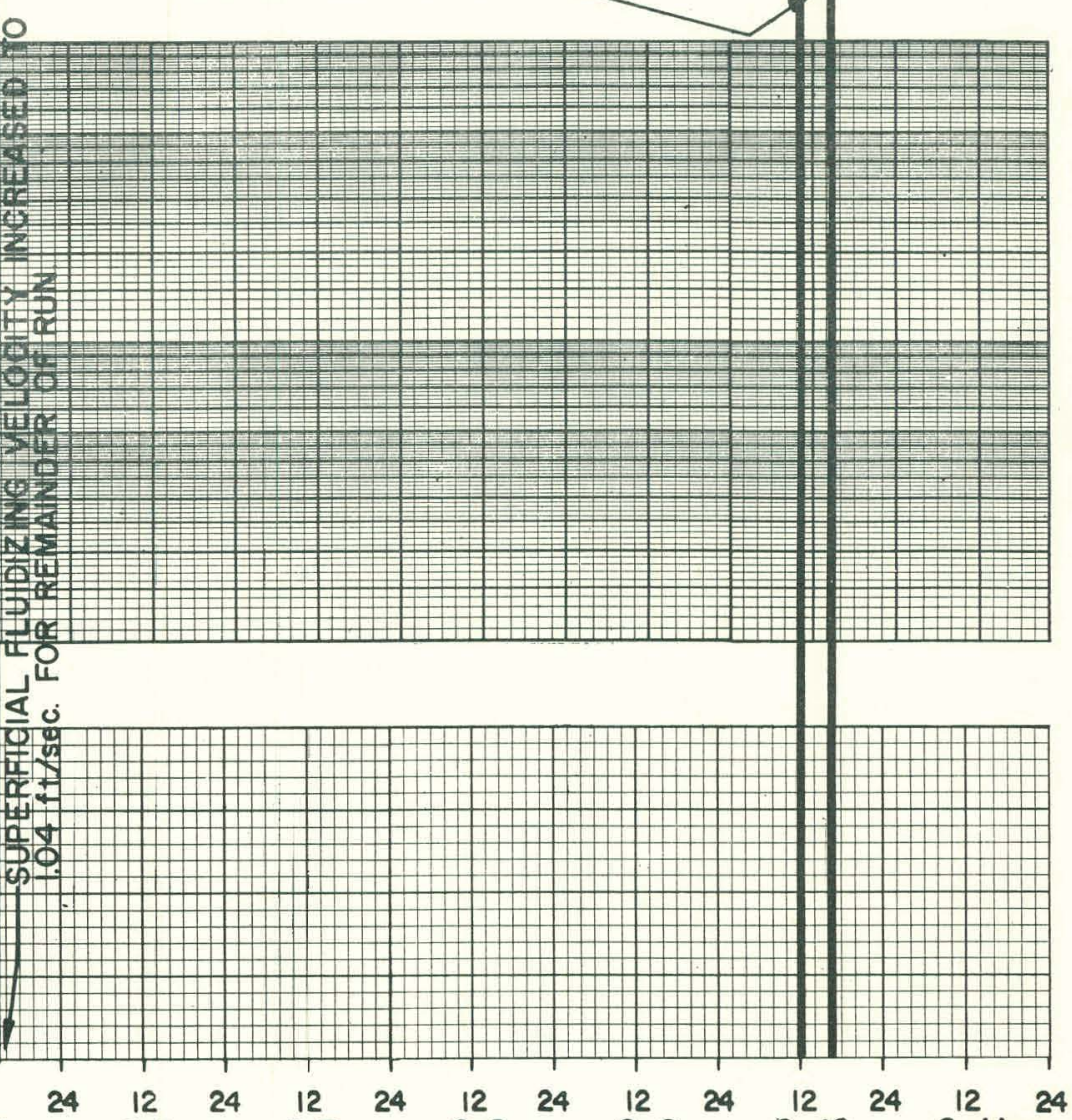

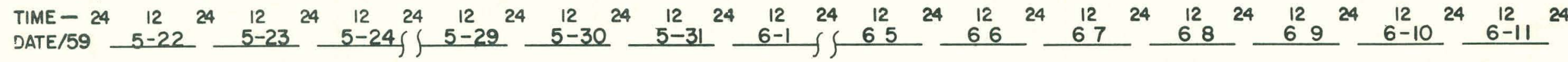

Fig. 22 General Data, Run 4 (Sheet 1 of 2) 
CALCINER 2-FT. RUN No. 4

FEED RATE 40 I/hr BED TEMP. $500^{\circ} \mathrm{C}$

NOZZLES: NO. 4 TYPE SS-I/4J AIR-TO-LIQUID VOLUME RATIO 306
SUPERFICIAL FLUIDIZING VELOCITY0.85-1.04ft/sec

DRY FINES RETURN $14.9 \rightarrow 13.2 \mathrm{scfm}$

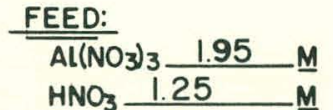

$\mathrm{NaNO}_{3}-0.089 \mathrm{M}$

$\mathrm{Hg}\left(\mathrm{NO}_{3}\right)_{2} \mathrm{O}$

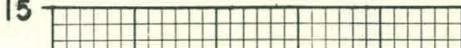

\begin{tabular}{l|l|l|}
\hline & & \\
\hline
\end{tabular}
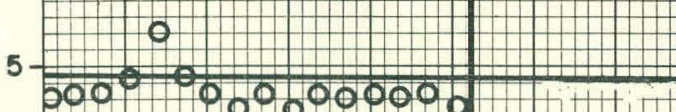

50000000000

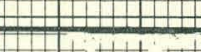

oH HIH H DOWN
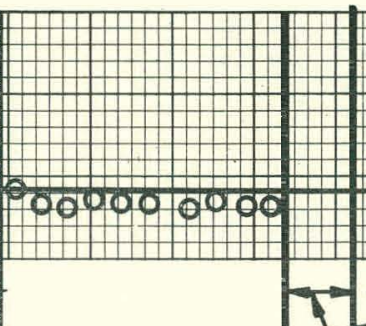

J THEDRETICAL PRODUCTION RATE = $4.31 \mathrm{~kg} / \mathrm{h}$ 100000000000000000000,0000 $0000^{\circ}$. DOWN (POWER FAILURE) DOWN(TO FILL NaK LOOP)

107

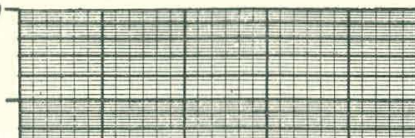

药
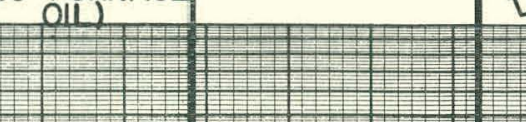
rown
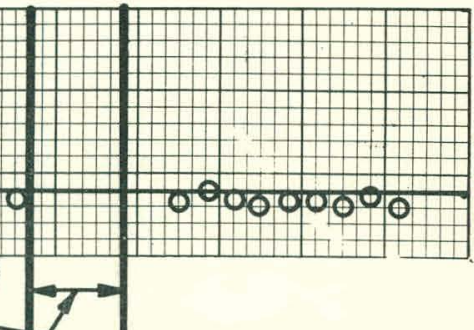

$1+0$
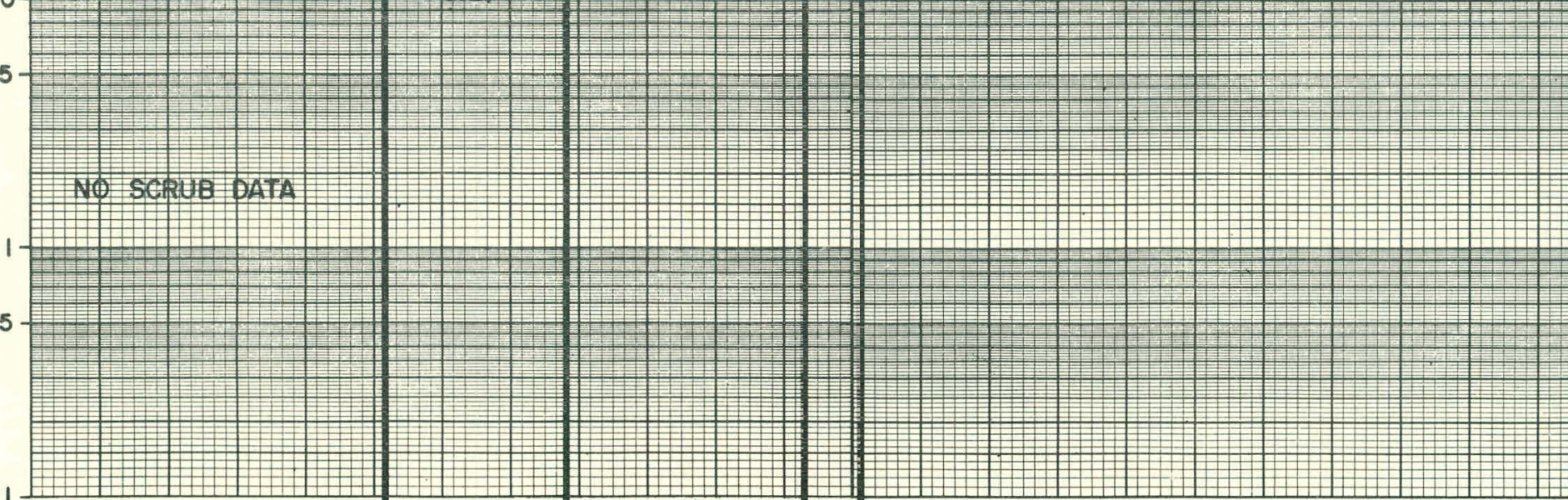

0.5

+
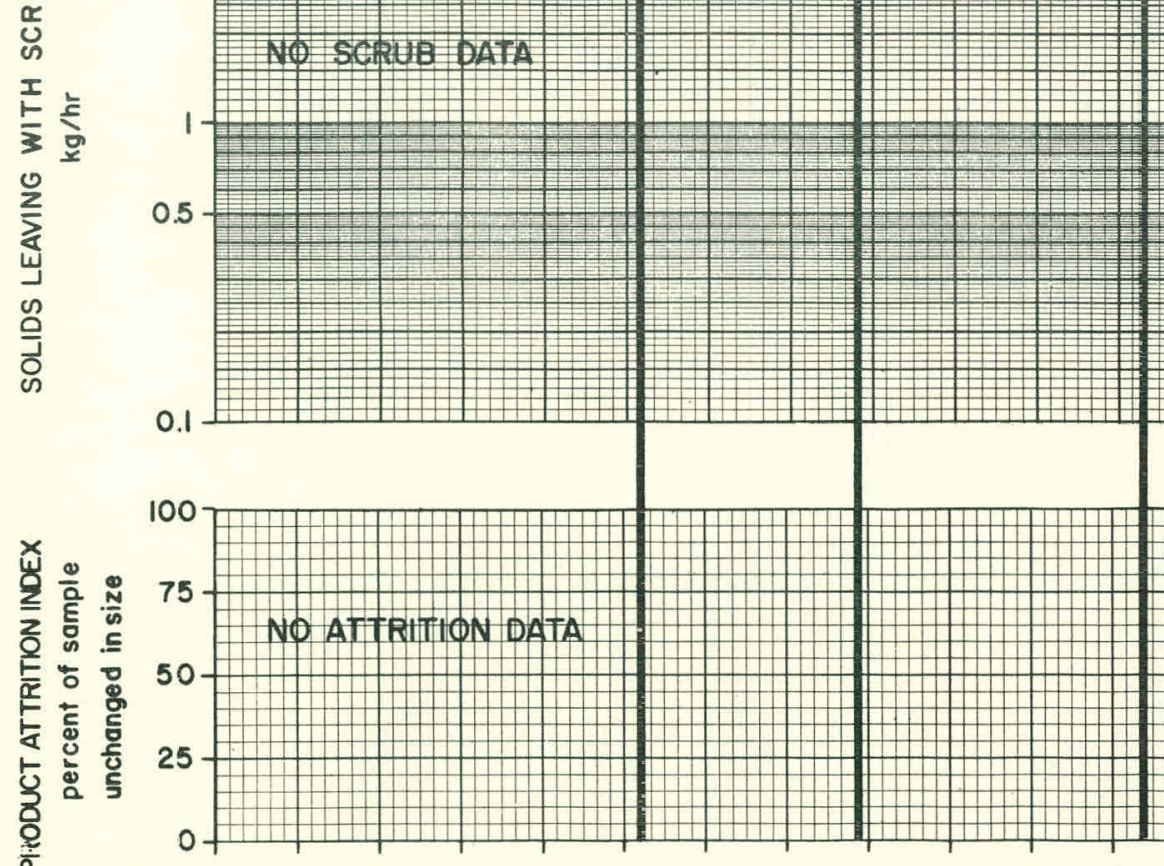

$+1+2$
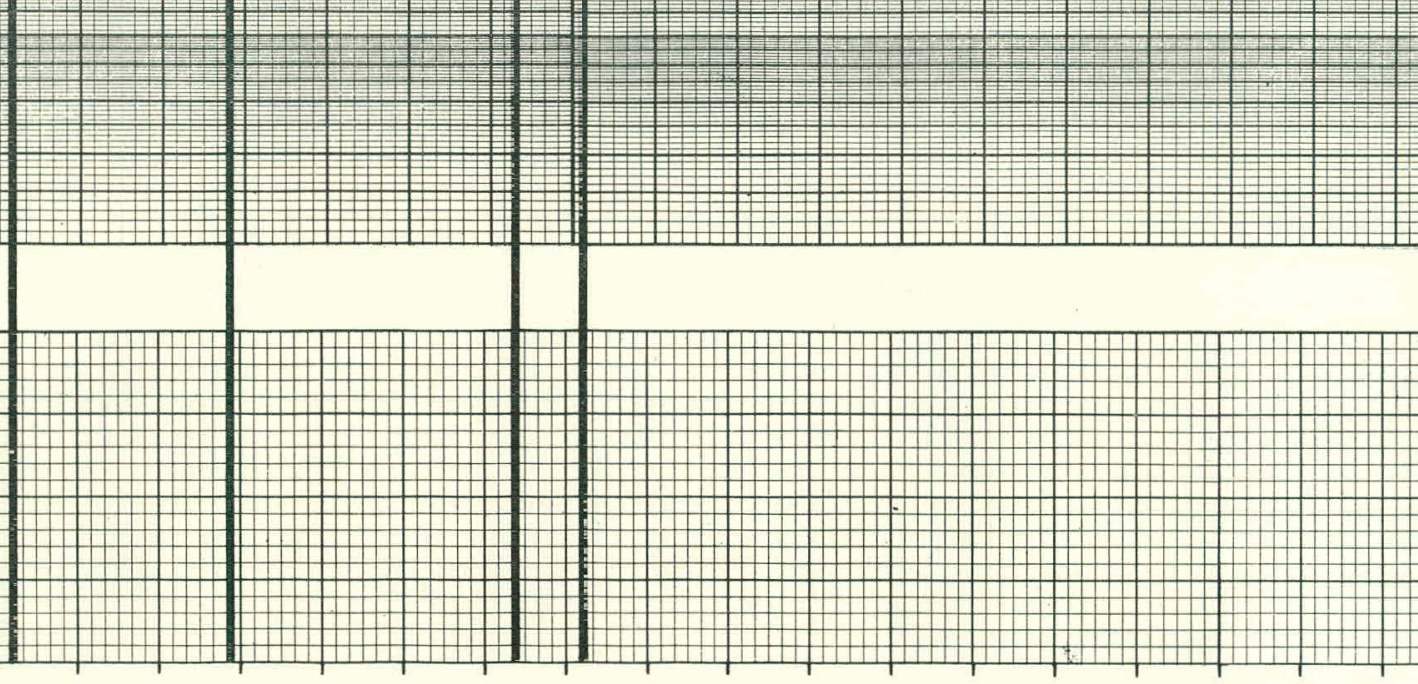

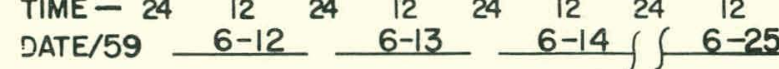

12
$6-26$

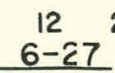

Fig. 22

General Data, Run 4 (Sheet 2 of 2) 
Period Covered: From July 7, 1959 to July 21, 1959

Objective: This was the third run made under the revised statistical program. The objectives remained the same as outlined for the previous runs, i.e., to obtain steadystate operating data to relate the product and off-gas characteristics with the calciner operating variables, and also to continue equipment development and evaluation.

Equipment: The equipment used during this run was the same as that used in Run 4.

Cumulative NaK Heating System Operating Data (including this run):

73 start-ups; 2280 hours above $1000^{\circ} \mathrm{F} ; 545$ hours below $1000^{\circ} \mathrm{F}$.

Run Conditione:

Bed temperature, ${ }^{\circ} \mathrm{C}$

Feed rate, $1 / \mathrm{hr}$

Nozzle air-to-liquid volume ratio

Number of Spraying Systems Company

$$
\text { Type } 1 / 4 \mathrm{~J} \text { nozzles }
$$

Total nozzle air rate, scfm

Superficial fluidizing velocity, ft/sec

Fccd Composition:
Part A Part B

$\begin{array}{rr}450 & 500 \\ 60 & 80 \\ 230 & 204 \\ & \\ 4 & 4 \\ 10 & 12 \\ 0.76 & 0.92\end{array}$

$\begin{array}{ll}1.95 & 1.95 \\ 1.25 & 1.25 \\ 0.089 & 0.089 \\ 0.006 & 0.006\end{array}$

Results: Results significant to the revised statistical program were not obtained during this run because steadystate operation was not achieved. A metallurgical examination of a section of the $\mathrm{NaK}$ loop indicated no significant corrosion.

Difficulties: The NaK heating system failed twice during this run when leaks occurred in the calciner Nak heat exchanger extemal to the calciner. The feed rate control system continued to give trouble throughout this run. Insufficient data were obtained to warrant publication. 
$\underline{\text { Run } 6}$

Period Covered: From November 12, 1959 to November 28, 1959

Objective: This run was made to determine the maximum feed rate at which the calciner would operate when calcining at a bed temperature of $500^{\circ} \mathrm{C}$ and using the newly altered equipment.

Equipment: The equipment used during this run was that used during Run 4, with the following changes:

1. Each of the four nozzle feed streams was controlled. by an integral flow nozzle $d / p$ cell transmitter and pneumatic recorder-controller.

2. Two of the four feed nozzles, alternate ones, were relocated to the opposite side of the calciner vessel.

3. The fluidizing air line was replaced with two lines, one a high-pressure ( $80 \mathrm{psig}$ ) air line looped through the calciner vessel above the bed, and the other a low-pressure (25 psig) line connected to the air preheater in the top of the NaK furnace.

4. The air distributor plate was replaced by a perforated plate having 3/16-inch holes on a 1 13/16-inch triangular pitch.

5. The electrical resistance-type NaK level detector in the NaK surge tank was replaced hy a General Electric "J-Tube" level detector.

6. A Moore Nullmatic pressure transmitter was added on the suction side of the $\mathrm{NaK}$ electromagnetic pump.

7. A Johnston pump equipped with aluminum oxide bearings was added to the scrub recycle system.

8. Two modifications were made on the NaK loop (modifications of the calciner NaK heating coil and replacement of a bypass valve).

Cumulative NaK Heating System Operating Data (including this mun):

85 start-ups; 2607 hours above $1000^{\circ} \mathrm{F} ; 668$ hours below $1000^{\circ} \mathrm{F}$.

Run Conditions:

Bed temperature, ${ }^{\circ} \mathrm{C} \quad 500$

Feed rate, $1 / \mathrm{hr} \quad 40-100$

Nozzle air-to-liquid volume ratio 486-195

Number of Spraying Systems Company Type 1/4 J nozzles 4 
Run 6 (continued)

Run Conditions: (continued)

Total nozzle air rate, scfm

14.8

Superficial fluidizing velocity, ft/sec

$0.89-1.03$

Feed Composition: Aluminum nitrate, $\mathrm{M}$

Nitric acid,
Sodium nitrate,
Mercuric nitrate, $\bar{M}$

Results: With the equipment used during this run, the calciner processed $100 \mathrm{l} / \mathrm{hr}$ of feed at a bed temperature of $500^{\circ} \mathrm{C}$.

Difficulties: Equipment operation during this run was generally satisfactory. Most of the troubles which had occurred during previous mus appeared to have been eliminated by the equipment modifications and replacements. A notable exception was the poor fluidization experienced throughout this run, resulting from the ineffectiveness of the new air distributor plate. 
CALCINER 2 Foot

FEED RATE $40^{*} \mathrm{l} / \mathrm{hr}$ BED TEMP $500^{\circ} \mathrm{C}$

NOZZLES: No.
SUPERFICIAL FLUIDIZING VELOCITY 1.03

DRY FINES RETURN_ 15 _ scfm
FEED:

$\mathrm{Al}\left(\mathrm{NO}_{3}\right)_{3}+{ }_{2.95} \mathrm{M}$

$\mathrm{HNO}_{3}-1.25$
NaNO3 $\quad 0.089 \quad M$

$\mathrm{Hg}\left(\mathrm{NO}_{3}\right)_{2} \stackrel{0.006}{\mathrm{M}}$

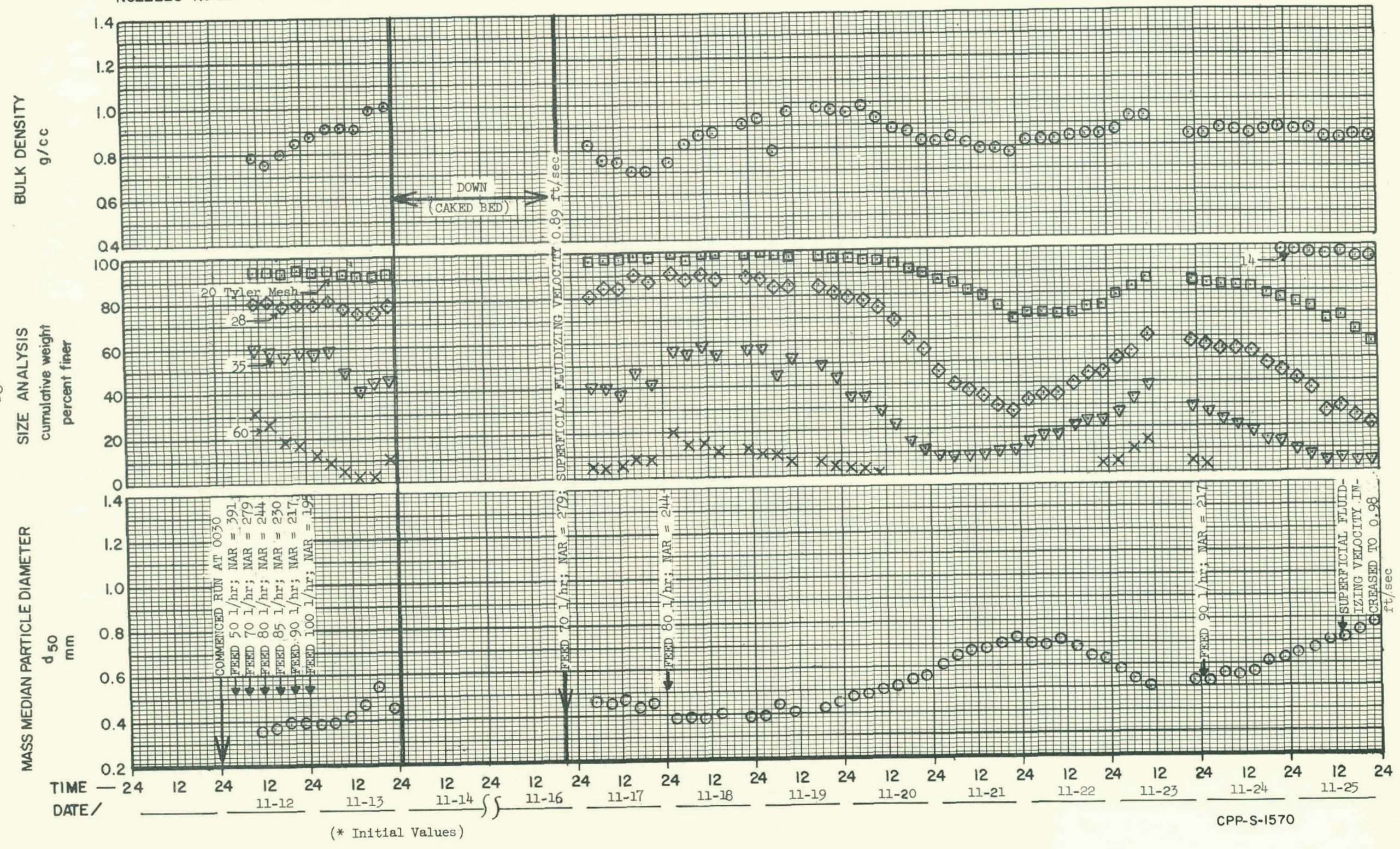

Fig. 23 Product Data, Run 6 (Sheet 1 of 2) 
CALCINER 2 Foot RUN No 6

FEED RATE $40^{*} / \mathrm{hr}$. BED TEMP $500^{\circ} \mathrm{C}$

NOZZLES: No. 4
SUPERFICIAL FLUIDIZING VELOCITY 1.03* DRY FINES RETURN_ 15 - scim
FEED:

$\mathrm{Al}\left(\mathrm{NO}_{3}\right)_{3} \quad 1.95$

$\mathrm{HNO}_{3} \longrightarrow 1.25 \mathrm{M}$
NaNO3 $\frac{0.089}{\mathrm{M}}$

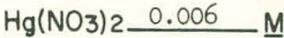

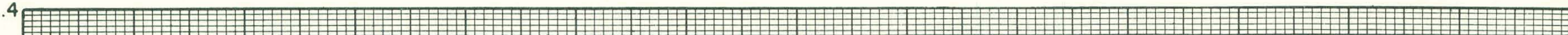

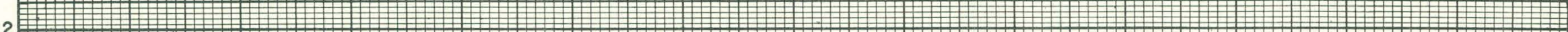

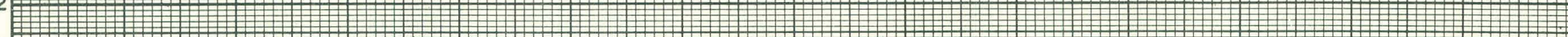

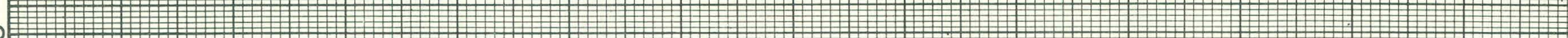

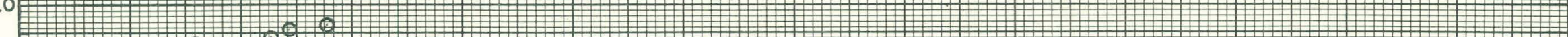

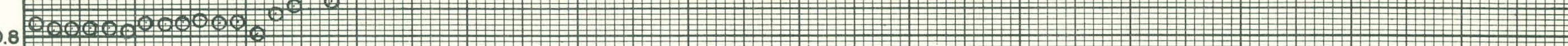

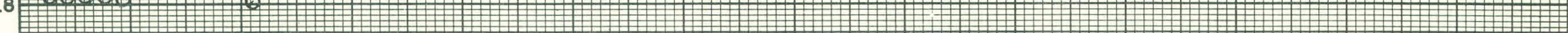

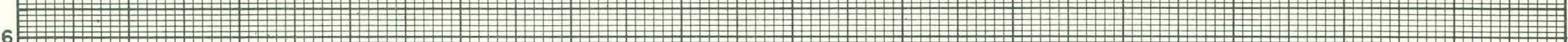

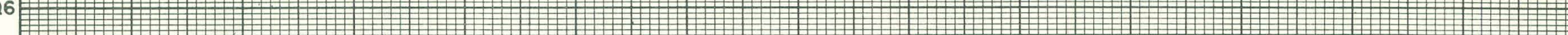

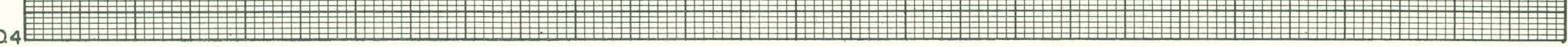

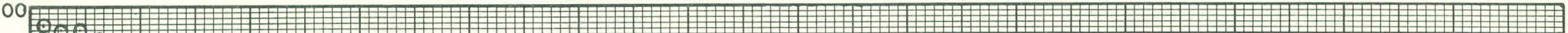

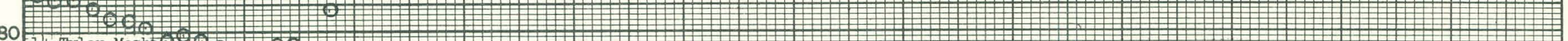

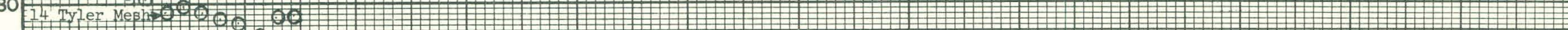

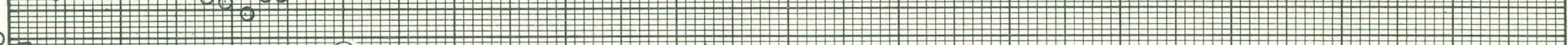

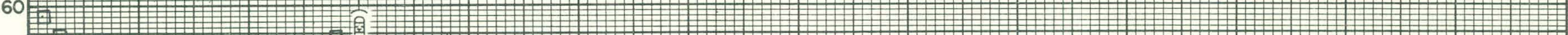

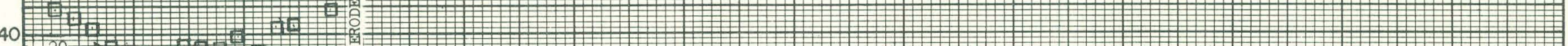

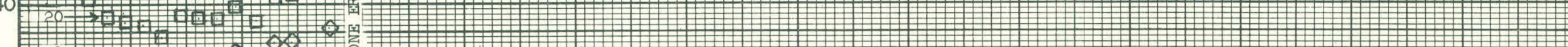

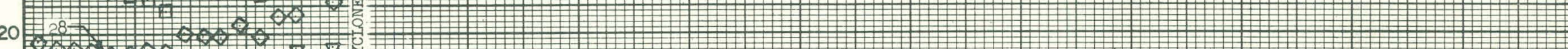

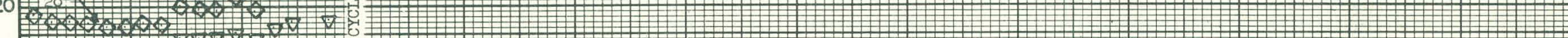

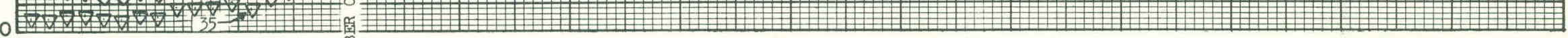

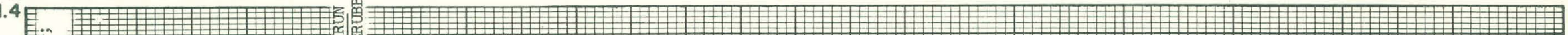

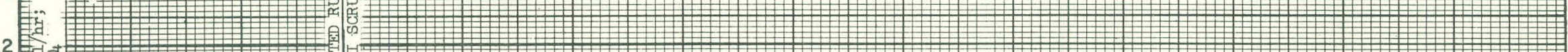

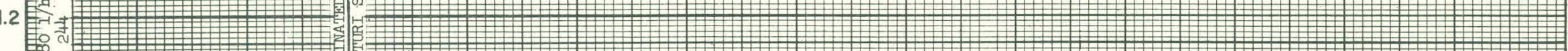
(

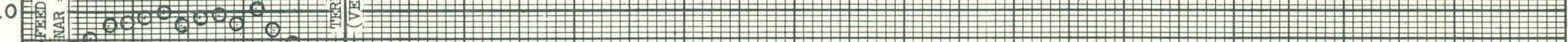

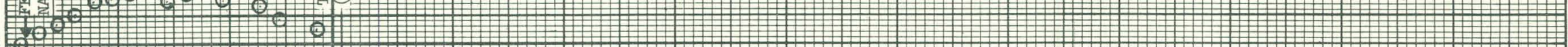

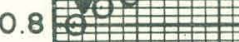

$+$

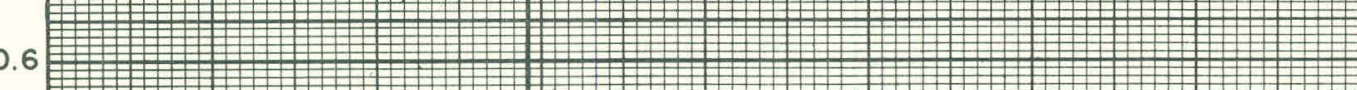

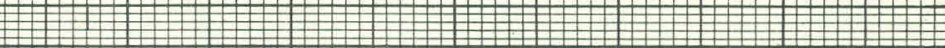

0.4

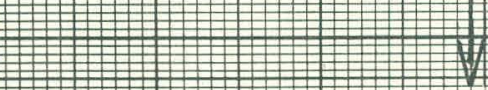

\begin{tabular}{lll}
\hline \\
\hline
\end{tabular}

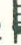

TIME $\begin{array}{llllll}24 & 12 & 24 & 12 & 24 & 12\end{array}$

DATE/ $11-26$

$24 \quad 12$

24

\begin{abstract}
12
\end{abstract}
Fig. 23 Product Data, Run 6 (Sheet 2 of 2) $\begin{array}{lllll}24 & 12 & 24 & 12 & 24\end{array}$

CPP-S-1570 


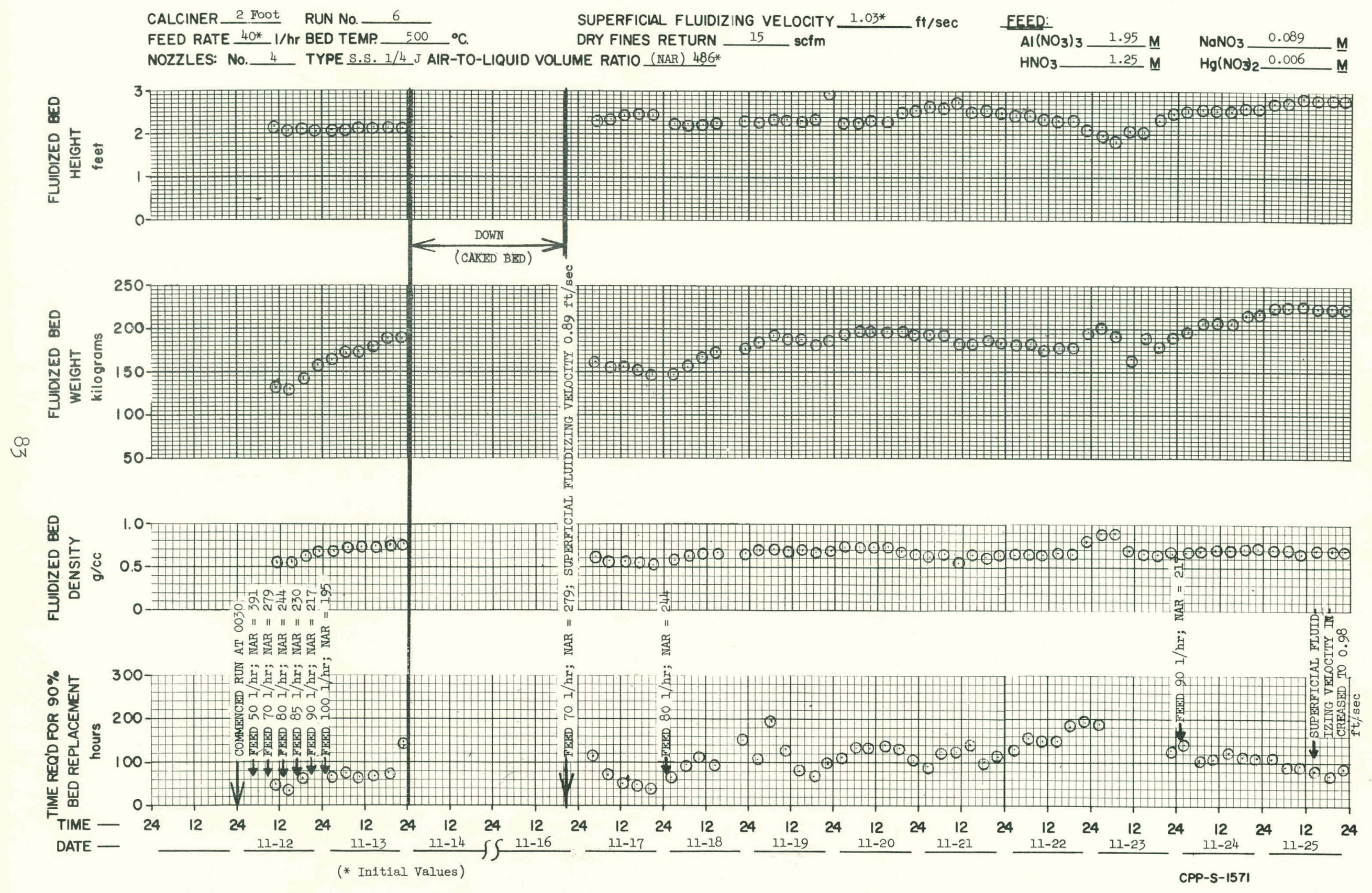

Fig. 24 Calciner Bed Data, Run 6 (Sheet 1 of 2) 
CALCINER 2 Foot RUN No. 6

FEED RATE $40 * 1 / \mathrm{hr}$ BED TEMP. $\frac{500}{\circ}{ }^{\circ} \mathrm{C}$
NOZZLES: NO. 4 TYPE S.S. I/4 JAIR-TO-LIQUID VOLUME RATIO (NAR) 486*

SUPERFICIAL FLUIDIZING VELOCITY 1.03*
FEED:

$\mathrm{Al}\left(\mathrm{NO}_{3}\right)_{3} \stackrel{1.95}{\mathrm{M}}$ $\mathrm{HNO}_{3}$
$\mathrm{NaNO}_{3}-0.089$ M

$\mathrm{Hg}\left(\mathrm{NO}_{3}\right) 0.006 \mathrm{M}$
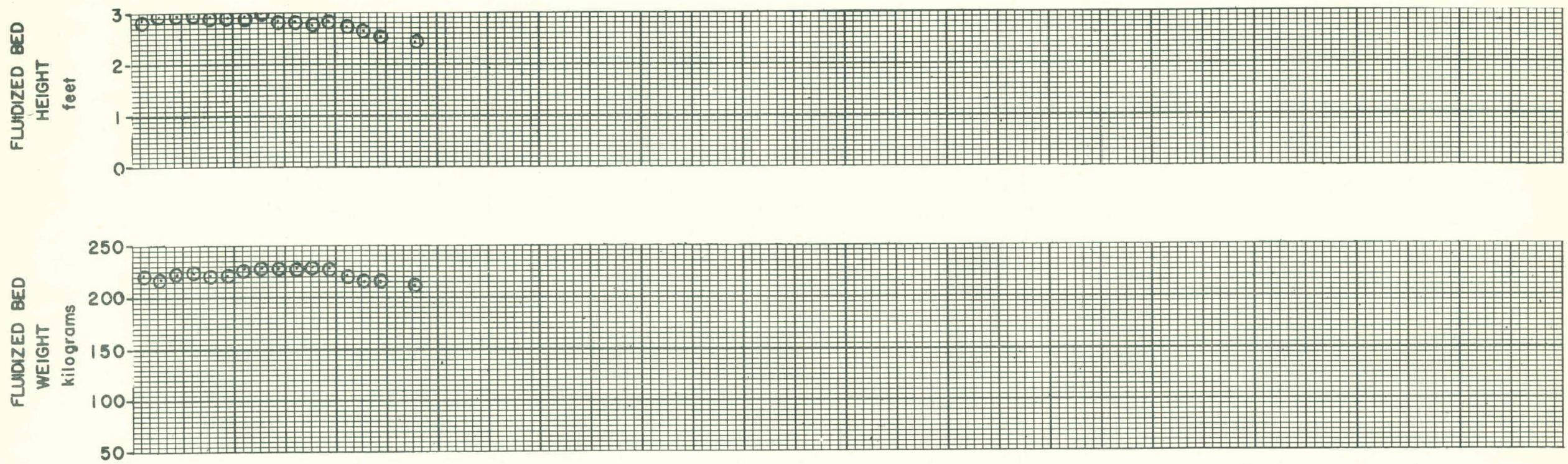

贯

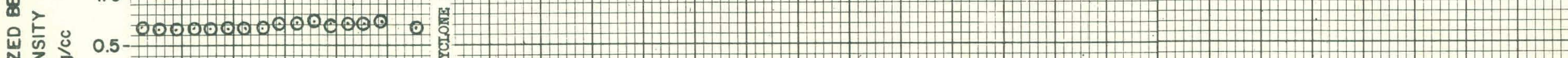

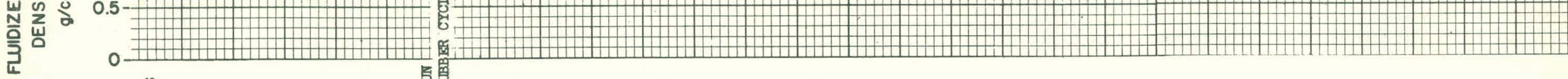

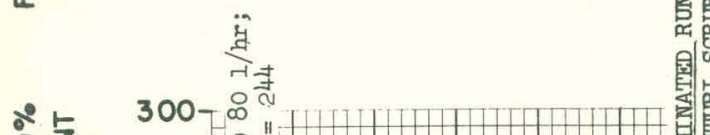

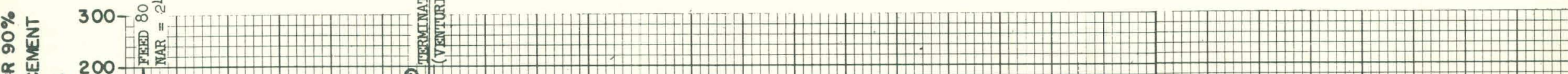

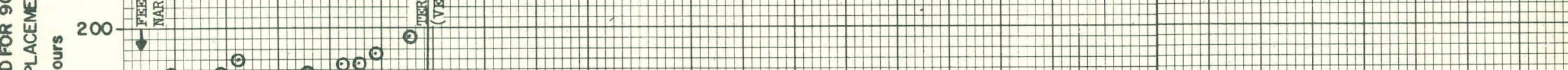

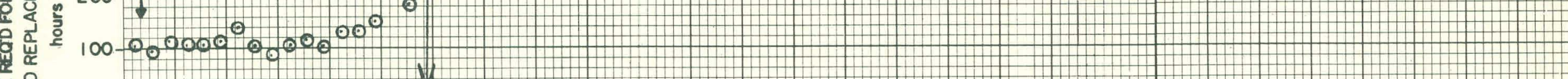

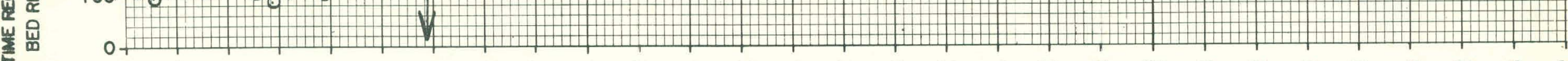

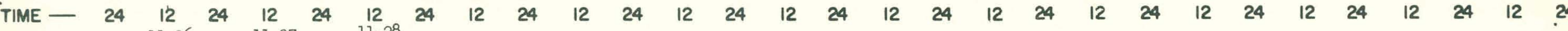
DATE - $11-26 \stackrel{11-27 \quad 11-28}{1}$

Fig. 24 Calciner Bed Data, Run 6 (Sheet 2 of 2)

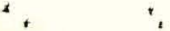


CALCINER 2 Foot RUN No. 6

FEED RATE $40 * \quad 1 / \mathrm{hr}$ BED TEMP. $500 \quad 0^{\circ} \mathrm{C}$

NOZZLES: No. 4
TYPE S.S. I/4 J AIR-TO-LIQUID VOLUME RATIO (TAR) 486*
SUPERFICIAL FLUIDIZING VELOCITY $1.03 * \mathrm{ft} / \mathrm{sec}$

DRY FINES RETURN $15 \quad$ scfm

(2)

FEED:

$\mathrm{Al}\left(\mathrm{NO}_{3}\right)_{3} \quad 1_{1.95} \mathrm{M} \quad \mathrm{NaNO}_{3}-0.089-\mathrm{M}$ $\mathrm{HNO}_{3}-1.25 \underline{\mathrm{Mg}} \quad \mathrm{Hg}\left(\mathrm{NO}_{3}\right)_{2} \underline{0.006} \underline{M}$
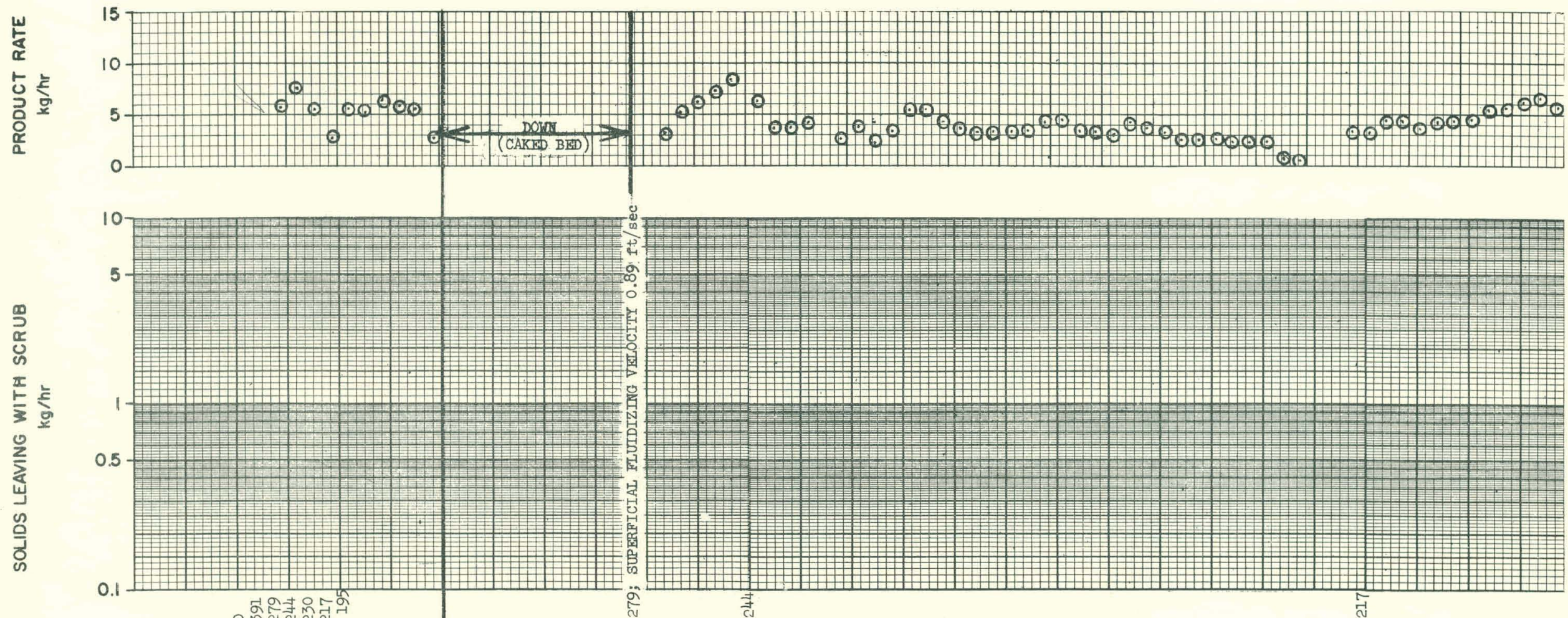

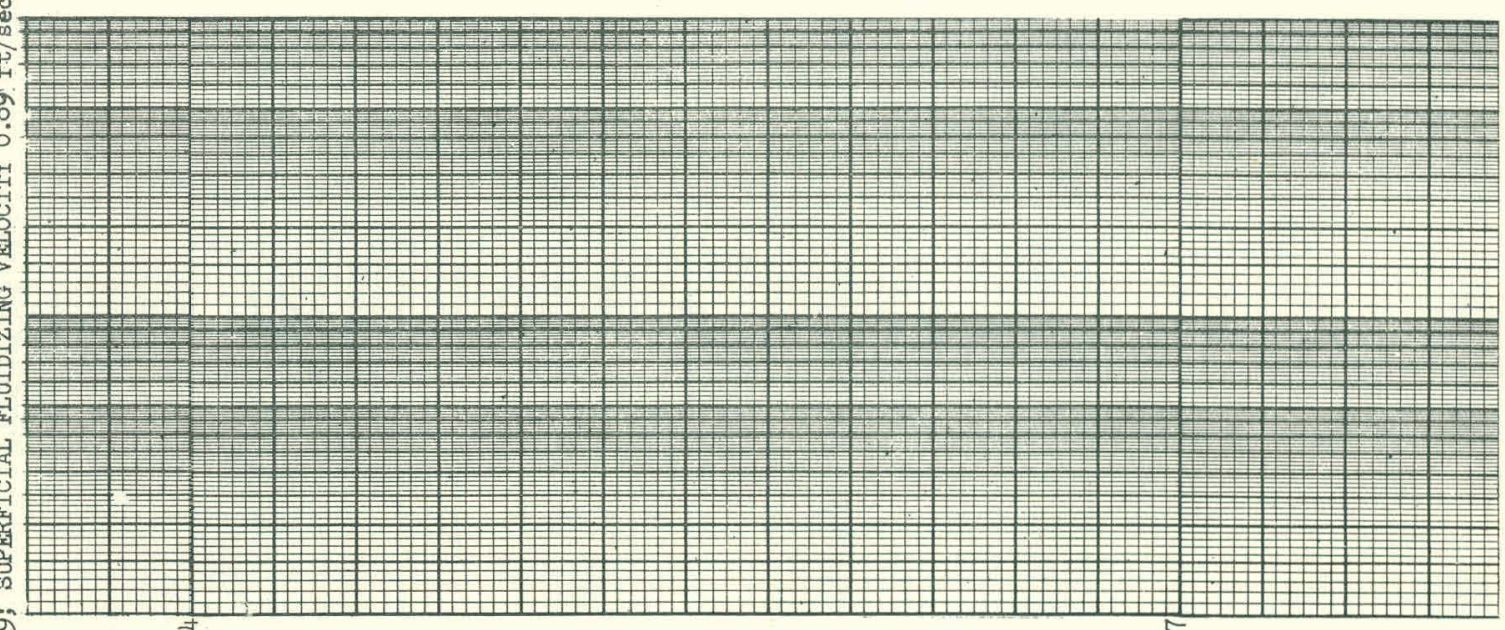

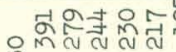

1007 W
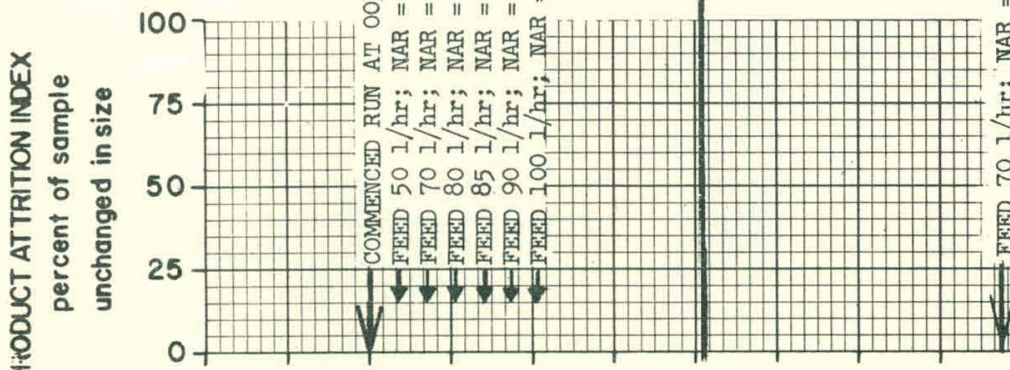
तै

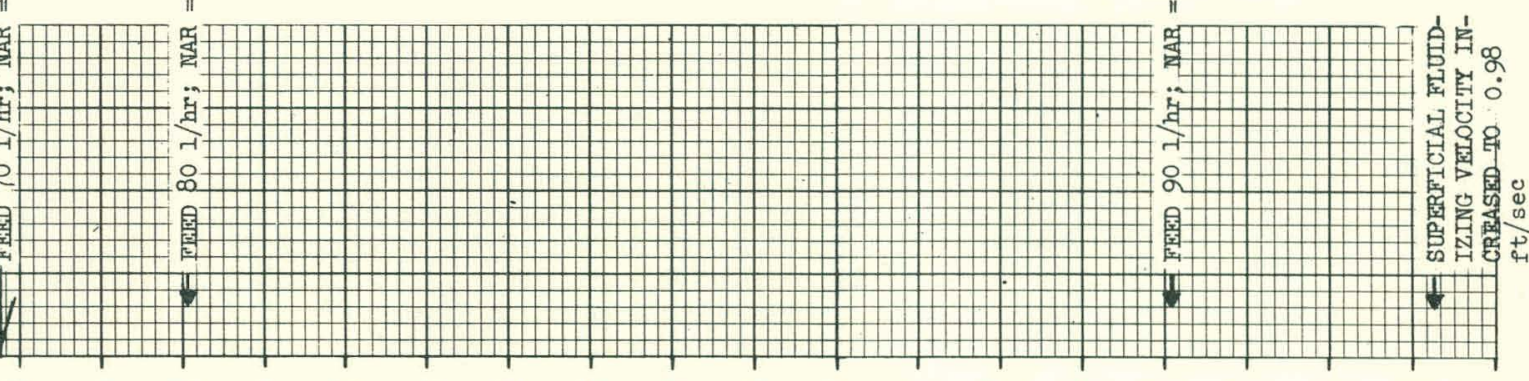
TIME 宾过连连遥 疄नНન

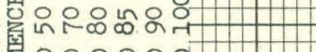

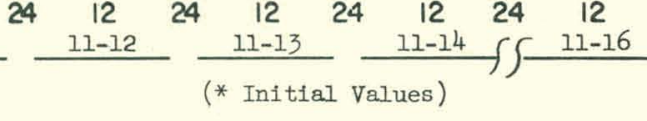

Fig. 25
General Data, Run 6 (Sheet 1 of 2)
CPP-S- 1573 
CALCINER 2 Foot RUN No. $\frac{6}{500}$ SUPERFICIAL FLUIDIZING VELOCITY $1.03^{*} \mathrm{ft} / \mathrm{seC}$

FEED RATE $40 * \frac{1}{2} 1 / \mathrm{hr}$ BED TEMP. $500 \quad 0^{\circ} \mathrm{C}$ NOZZLES: No. 4 TYPES.S. I/4 J AIR-TO-LIQUID VOLUME RATIO (NAR) 486*
FEED:

$\mathrm{Al}\left(\mathrm{NO}_{3}\right)_{3} \quad \frac{1.95}{\mathrm{M}} \quad \mathrm{NaNO}_{3}-0.089-\mathrm{M}$

$\mathrm{HNO}_{3} \frac{1.25}{-M} \quad \mathrm{Hg}\left(\mathrm{NO}_{3}\right)_{2} \frac{0.006}{-M}$
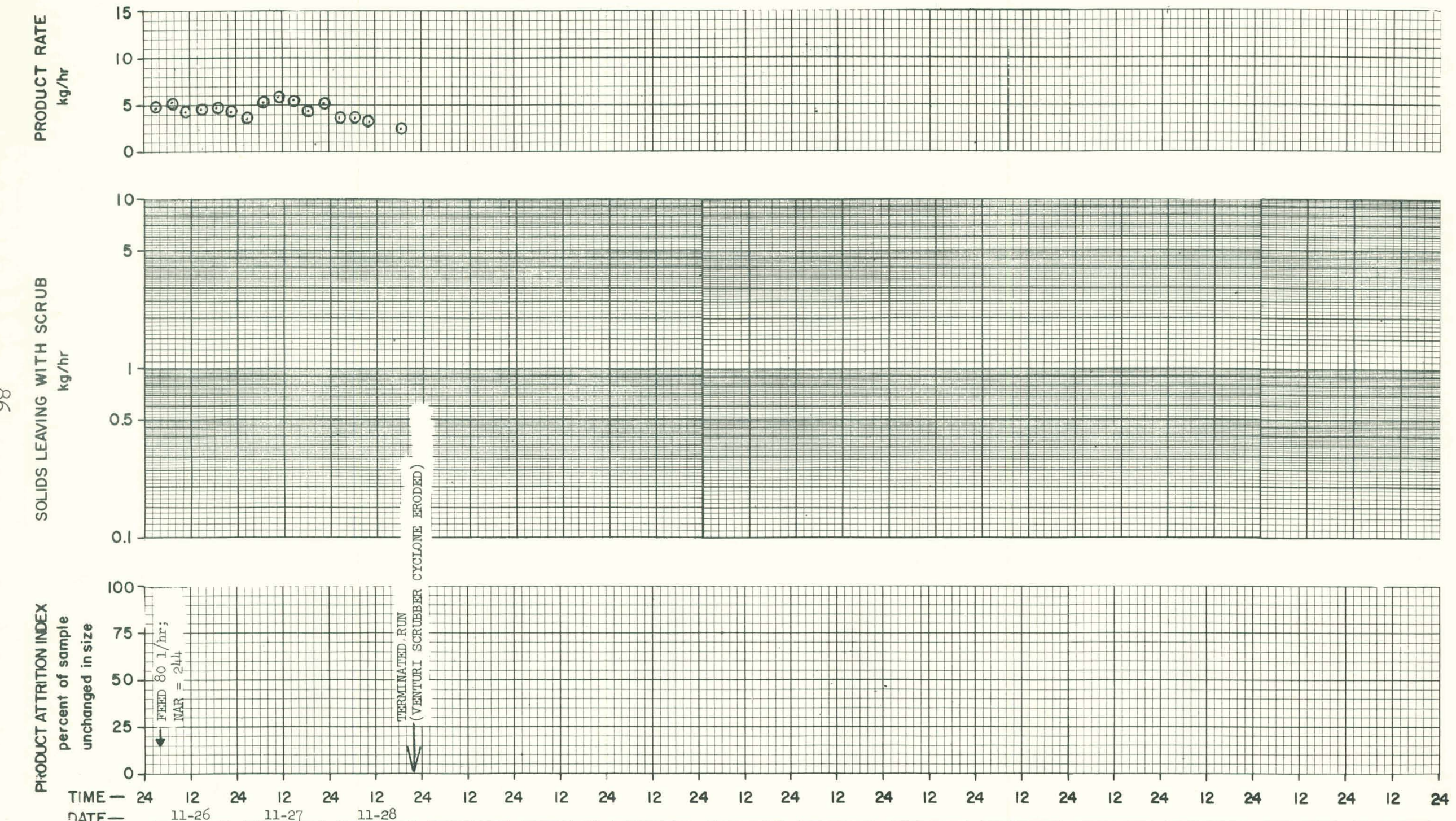

Fig. 25 Genera Data, Run 6 (Sheet 2 of 2)

CPP.S- 1573 
Run 7

Period Covered: From November 29, 1959 to January 19, 1960

Objective: The objective of this run was to test the fluidization characteristics of various air distributor plates and to select one for future calciner use.

Equipment: The equipment used during this run was that used in Run 6, except that various air distributor plates were tested and the Johnston pump was removed after the aluminum oxide bearings failed during Run 6 .

Cumulative NaK Heating System Operating Data (including this run):

101 start-ups; 2900 hours above $1000^{\circ} \mathrm{F} ; 772$ hours below $1000^{\circ} \mathrm{F}$.

Run Conditions: Generally, the bed was heated to $500^{\circ} \mathrm{C}$, and during the transient heating period the temperatures of two in-bed thermocouples were observed. If the temperatures indicated by the two thermocouples were nearly identical, good fluidization was indicated. A superficial fluidizing velocity of from 0.6 to $0.7 \mathrm{ft} / \mathrm{sec}$ was used. The quality of fluidization was determined also by observing the top of the bed through glass viewing ports.

Results: One of the air distributor plates gave consistently good fluidization, and therefore was selected for use during future runs.

Difficulties: No particular equipment troubles were observed during this run, except those associated with the poor air distributor plates. 
$\underline{\operatorname{Run} 8}$

Period Covered: From January 20, 1960 to February 6, 1960

Objective: The objective of this mun was to determine the minimum superficial fluidizing velocity at which the calciner would continue to operate indefinitely at a feed rate of 80 liters per hour, at a calcination temperature of $500^{\circ} \mathrm{C}$, and while operating with a nozzle air-to-liquid volume ratio of 282 .

Equipment: The equipment used during this run was that used for Run 7, except that the best bed support plate tested during Run 7 was adopted. This plate contained twenty-four 3/8-inch-diameter holes drilled in a, 1/8-inch 1) 7 atte nn a $4 \frac{1}{2}$-inch-square pitch. Diclso wore positioncd over these holes to prevent the bed from draining.

Cumulative NaK Hoating Eystcm Opcrating Dala (inlluding llıs run):

103 start-ups; 3288 hours above $1000^{\circ} \mathrm{F} ; 785$ hours below $1000^{\circ} \mathrm{F}$.

Run Conditions:

Bed temperature, ${ }^{\circ} \mathrm{C} \quad 500$

Feed rate, $1 / \mathrm{hr}$

Nozzle air-to-liquid volume ratio

Number of Spraying Systems Company Type $1 / 4 \mathrm{~J}$ nozzles Superficial fluidizing velocity, ft/sec

Dry fines return

282

4

$0.78,0.59$

Yes

Feed Composition: Aluminum nitrate, M 1.95

Nitric acid, $\quad \vec{M} \quad 1.25$

Dodiunilidiale, $\bar{M} \quad 0.008 y$

Mercuric nitrate, $\underline{\bar{M}} \quad 0.006$

Results: The objective of this run was not achieved. About 36 hours after the fluidizing air velocity was reduced from the original value, the bed caked. Since other factors may have contributed to the caked bed, a minimum fluidization velocity was not established.

Difficulties: Repeated brief shutdowns of the oil-fired NaK system occurred during this run. Aluminum nitrate crystals in the feed caused some minor feed controller troubles. 
CALCINER 2 ft. RUN No. 8

FEED RATE $80.3 \mathrm{l} / \mathrm{hr}$. BED TEMP. $500{ }^{\circ} \mathrm{C}$

NOZZLES: No. 4
SUPERFICIAL FLUIDIZING VELOCITY $0.8-0.59 \mathrm{ft} / \mathrm{sec}$

DRY FINES RETURN Yes
FEED:

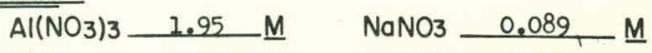$$
\mathrm{HNO}_{3} \quad \mathrm{I}_{2} 25 \mathrm{M} \quad \mathrm{Hg}\left(\mathrm{NO}_{3}\right)_{2} 20.006 \quad M
$$

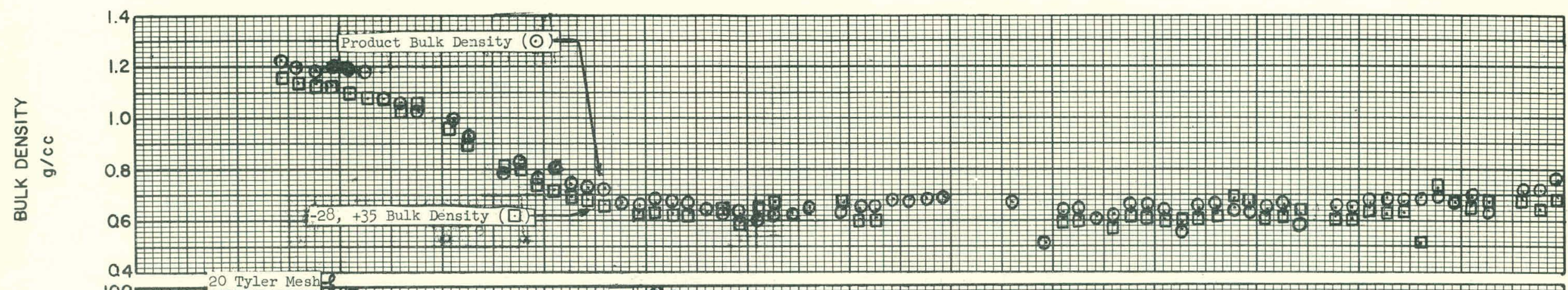

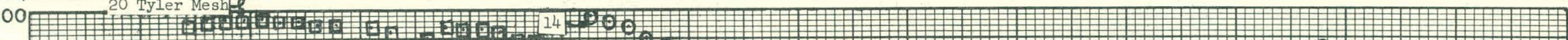

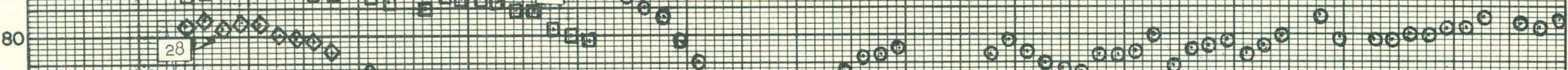

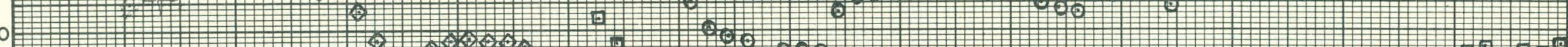
\begin{tabular}{l}
\hline \\
\hline
\end{tabular} (

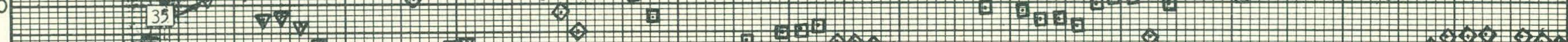

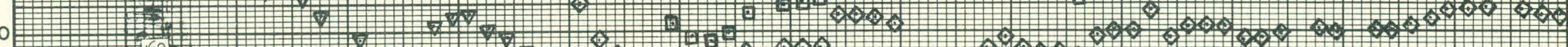

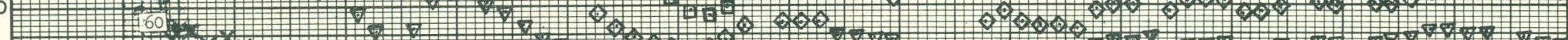

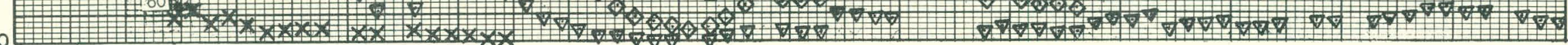

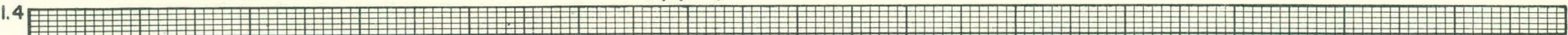

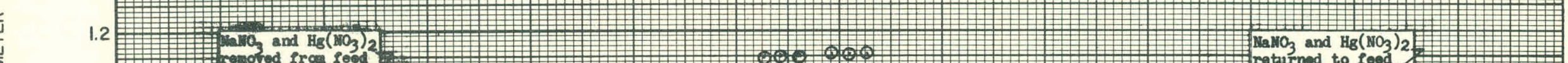
(

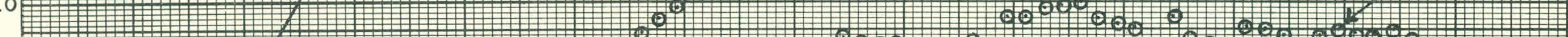

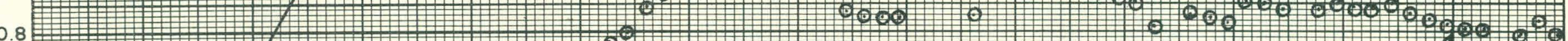

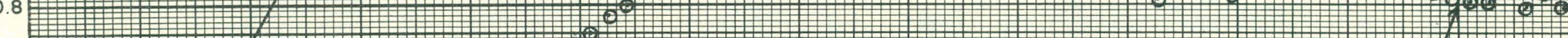

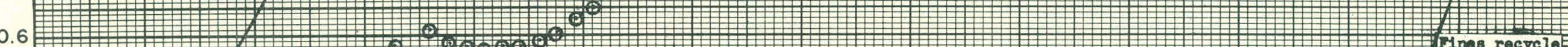

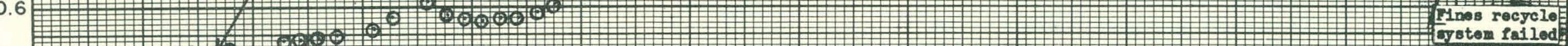

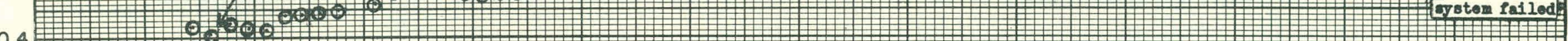

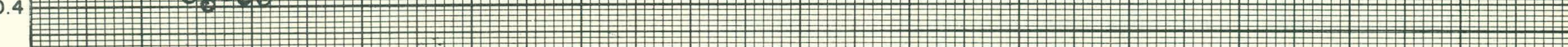

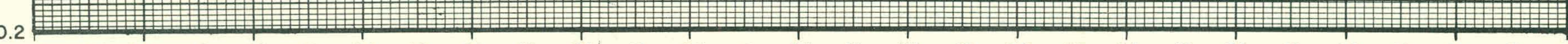

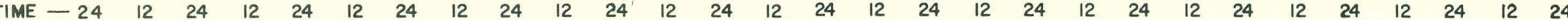

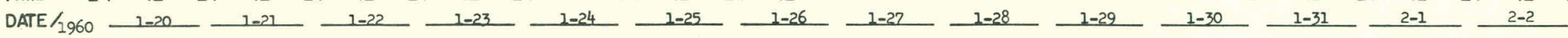


CALCINER 2 ft. RUN No. R 8

FEED RATE $80,3 \mathrm{l} / \mathrm{hr}$. BED TEMP. $-500{ }^{\circ} \mathrm{C}$

NOZZLES: No. 4
SUPERFICIAL FLUIDIZING VELOCITY $0.8-0.59 \mathrm{ft} / \mathrm{sec}$

DRY FINES RETURN_ Yes
FEED:

$\mathrm{Al}\left(\mathrm{NO}_{3}\right)_{3} \quad 1.95$

$\mathrm{HNO}_{3} 1.25$ M
$\mathrm{NaNO}_{3}-0.089 \mathrm{M}$

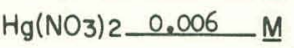

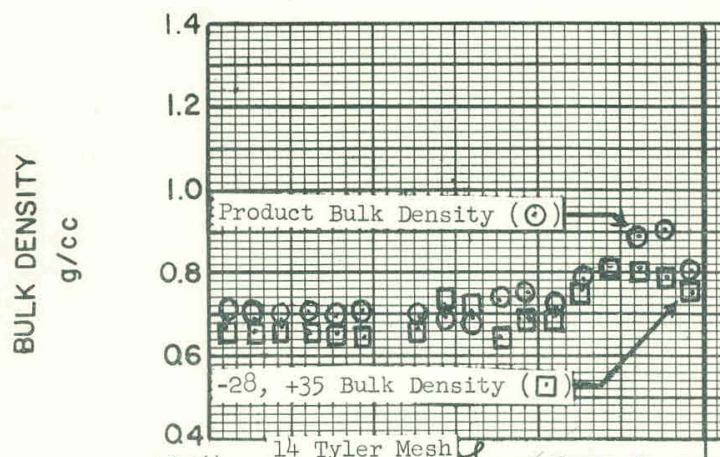

$\begin{array}{r}\text { I } \\ \hline\end{array}$

$100 \quad 14$ Tyler Mesh

100 Poona

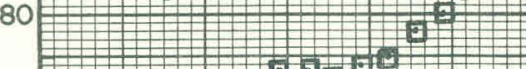

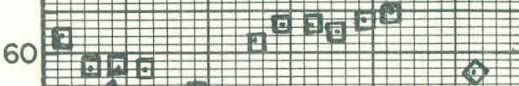

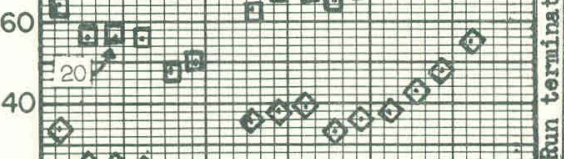

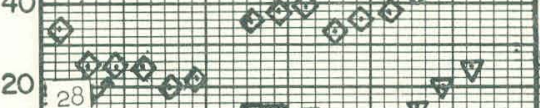

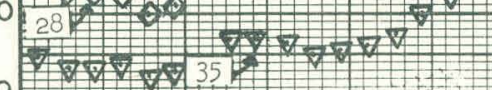

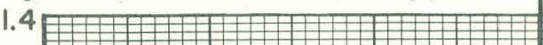
M
n

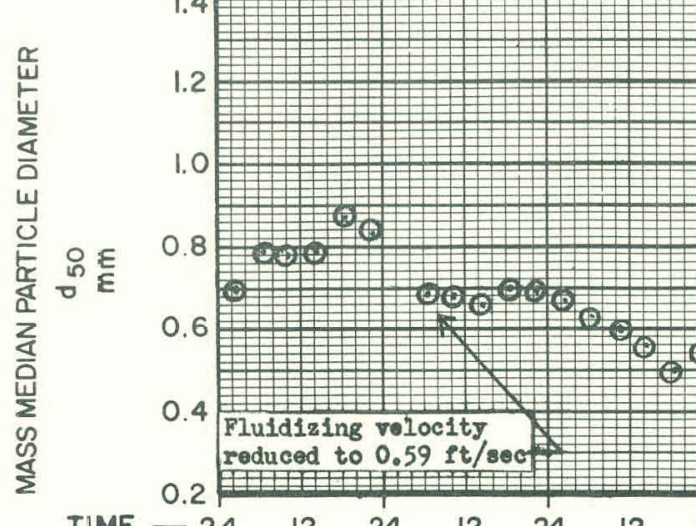

TIME $\begin{array}{lllllll}-24 & 12 & 24 & 12 & 24 & 12 & 24\end{array}$

DATE $/ 1960$ $2-4$ $2-5$
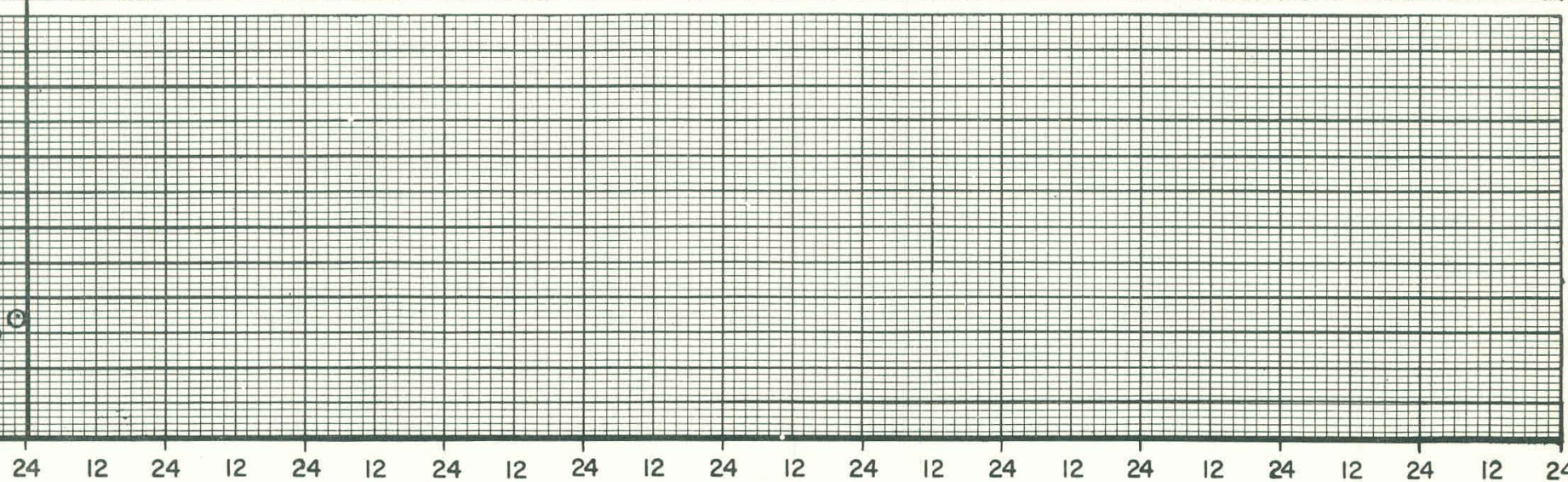

Fig. 26 Product Data, Run 8 (Sheet 2 of 2) 
CALCINER $2 \mathrm{ft}$. RUN No. 8

FEED RATE $80.3 \mathrm{l} / \mathrm{hr}$ BED TEMP. $500{ }^{\circ} \mathrm{C}$.

NOZZLES: NO. 4 TYPES.S.TYPE : 4 -JAIR-TO-LIQUID VOLUME RATIO 282
SUPERFICIAL FLUIDIZING VELOCITY $\underline{0.8-0.59} \mathrm{f} / \mathrm{sec}$

Yes
FEED:

$\mathrm{Al}\left(\mathrm{NO}_{3}\right)_{3}+1.95 \mathrm{M} \quad \mathrm{NaNO}_{3} \quad 0.089$

$\mathrm{HNO}_{3} \mathrm{I}_{2.25} \mathrm{M} \quad \mathrm{Hg}\left(\mathrm{NO}_{3}\right)_{2}-0.006 \underline{\mathrm{M}}$
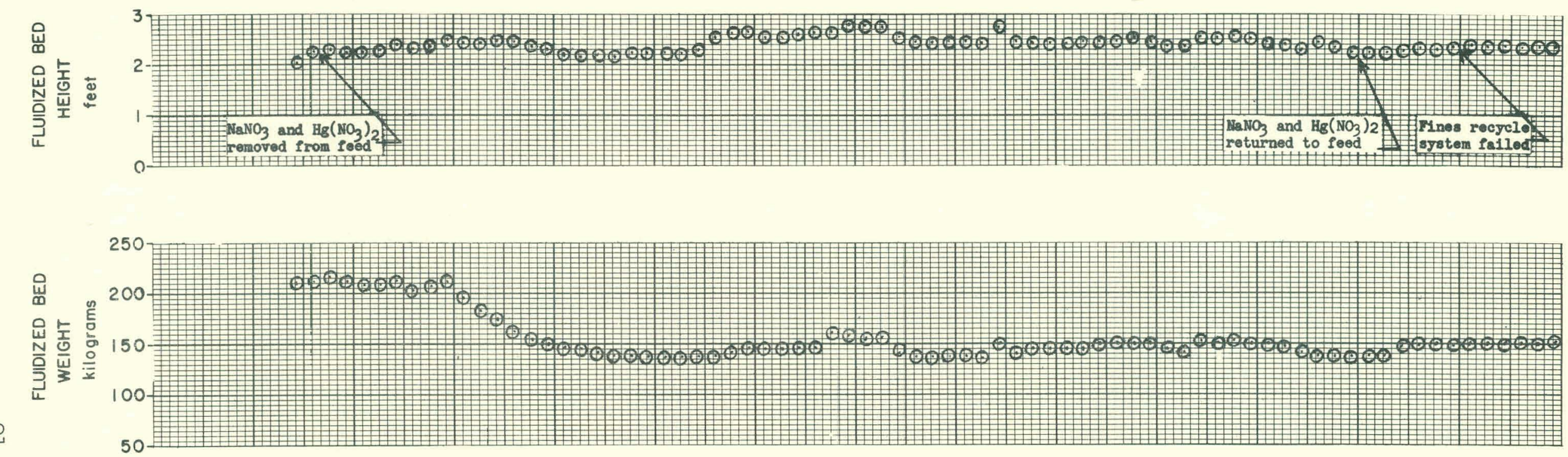

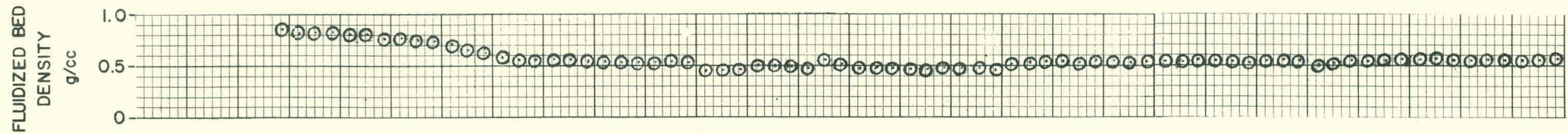

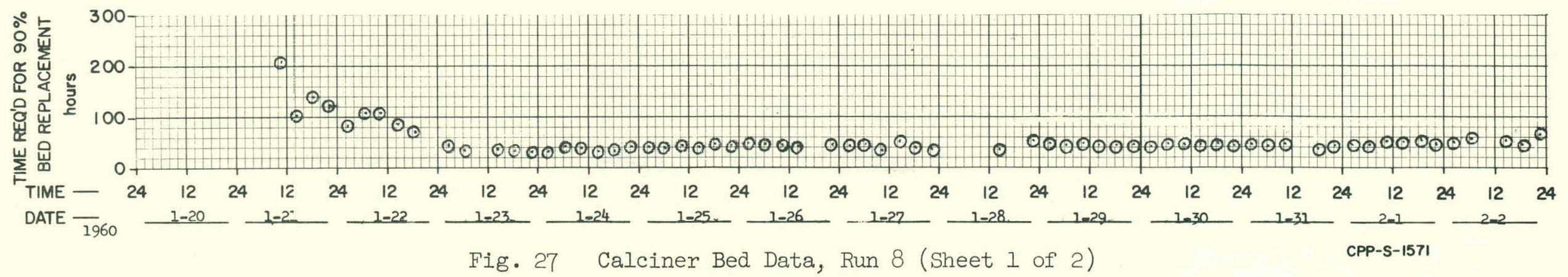


CALCINER 2 ft. RUN No. 8

FEED RATE $80.3 \mathrm{l} / \mathrm{hr}$ BED TEMP. $500{ }^{\circ} \mathrm{C}$.

SUPERFICIAL FLUIDIZING VELOCITY $0.8-0.59 \mathrm{ft} / \mathrm{sec}$

NOZZLES: NO. 4 TYPE S.S.TYPE KWAIR-TO-LIQUID VOLUME RATIO 282
FEED:

$\mathrm{Al}\left(\mathrm{NO}_{3}\right)_{3}+1.95 \mathrm{M}$

$\mathrm{NaNO}_{3} \frac{0.089}{-\mathrm{M}}$

$\mathrm{HNO}_{3}-1.25 \mathrm{M}$
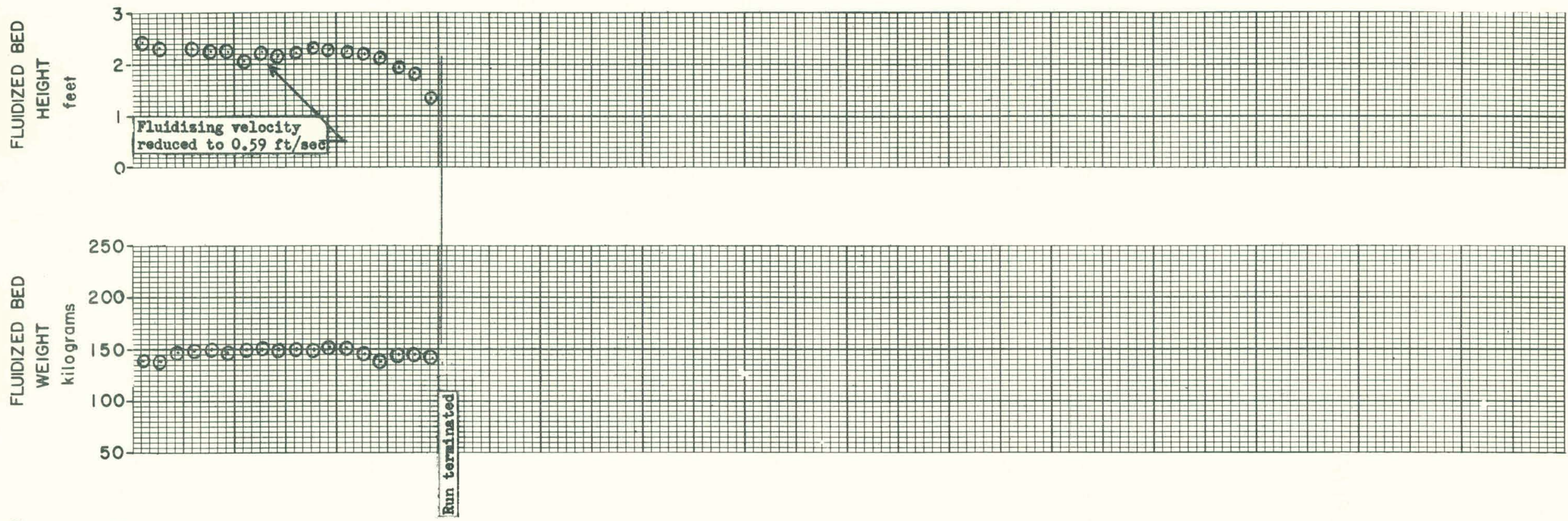

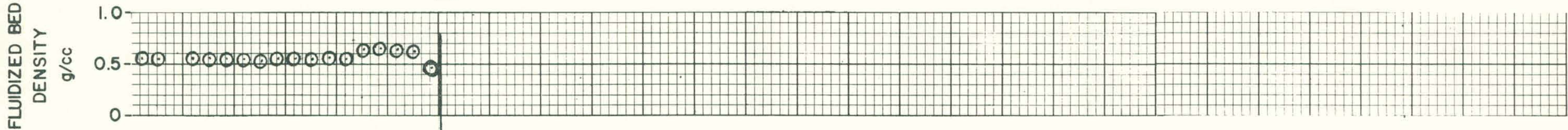

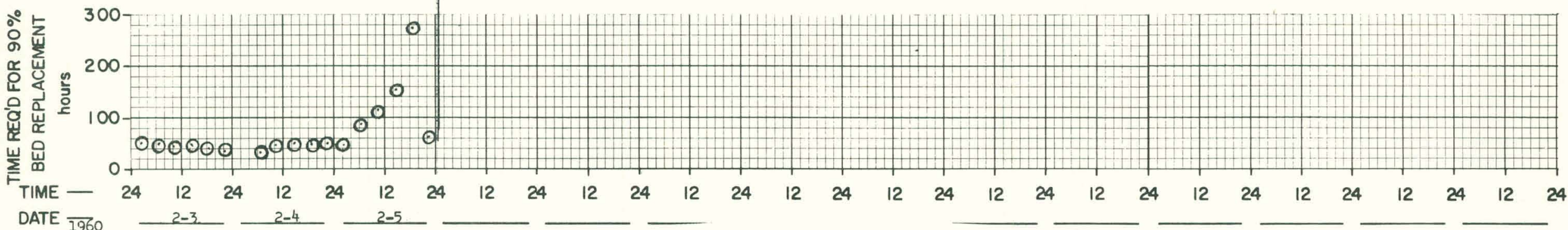

Fig. 27 Calciner Bed Data, Run 8 (Sheet 2 of 2) 


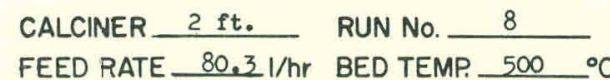

NOZZLES:

TYPE S.S. Type $y_{4}-J$

- TYPE

SUPERFICIAL FLUIDIZING VELOCITY $0.8-0.59 \mathrm{f} \uparrow / \mathrm{sec}$

DRY FINES RETURN Yes

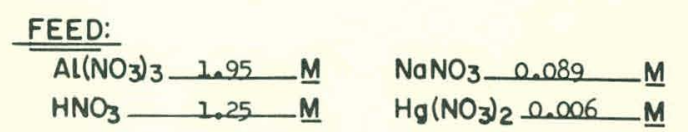
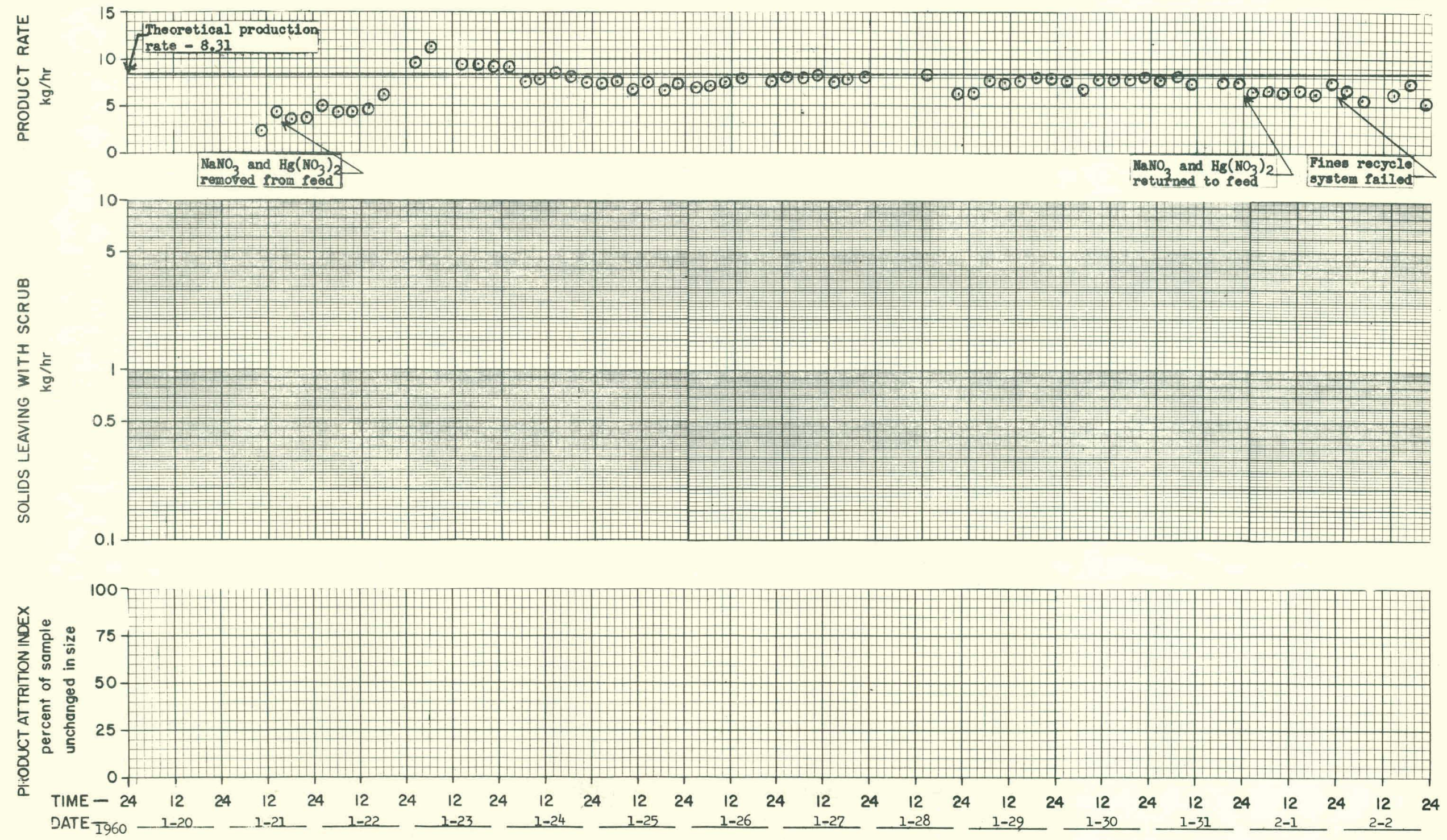

Fig. 28 General Data, Run 8 (Sheet 1 of 2) 
CALCINER $2 \mathrm{ft}$. RUN No. 8

FEED RATE $80.3 \mathrm{I} / \mathrm{hr}$ BED TEMP. $500{ }^{\circ} \mathrm{C}$ NOZZLES: No. 4
$500{ }^{\circ} \mathrm{C}$ DRY FINES RETURN Yes

TYPE S.S. TYPe 1/4J AIR-TO-LIQUID VOLUME RATIO 282
FEED:

$\mathrm{Al}\left(\mathrm{NO}_{3}\right)_{3} \mathrm{I}_{2} \mathrm{M} \quad \mathrm{M} \quad \mathrm{NaNO}_{3}-0.089-\mathrm{M}$

$\mathrm{HNO}_{3}-1.25-M \quad \mathrm{Mg}\left(\mathrm{NO}_{3}\right)_{2} \underline{0.006} \underline{\mathrm{M}}$

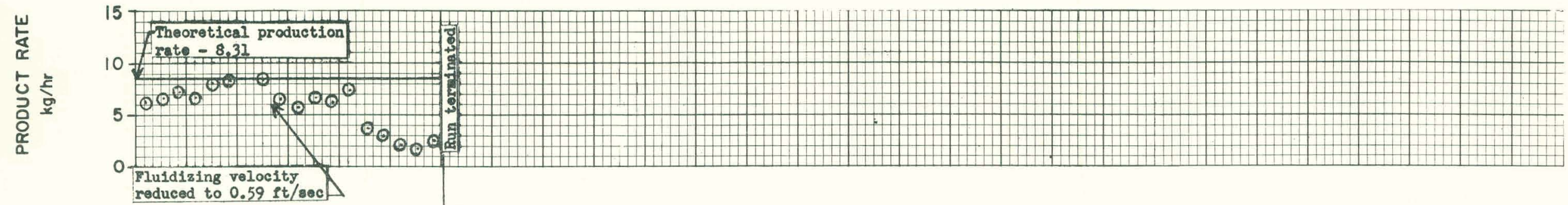
reduced to $0.59 \mathrm{ft} / \mathrm{sec}$
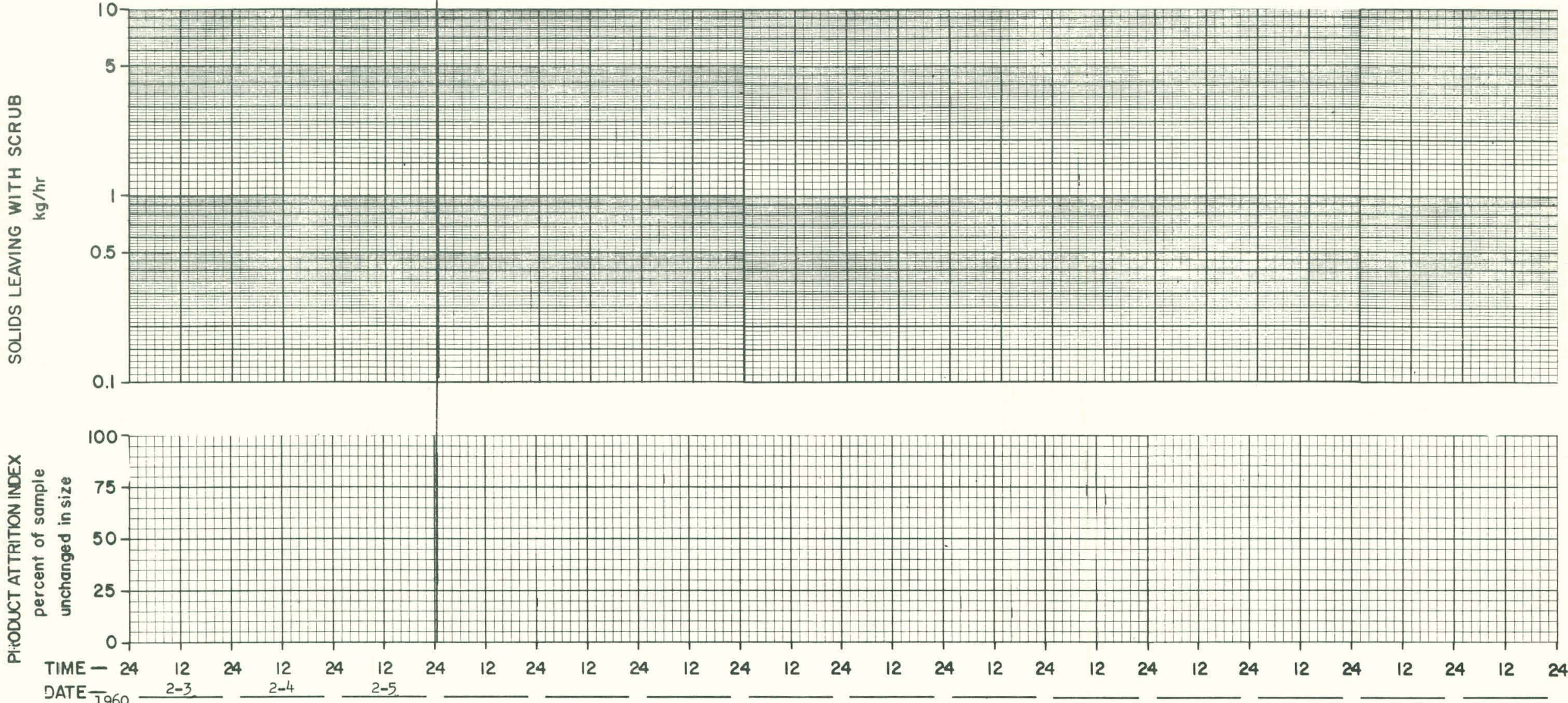

Fig. 28

General Data, Run 8

(Sheet 2 of 2)

CPP-S- 1573 
$\underline{\operatorname{Run} 9}$

Period Covered: From March 13, 1960 to April 20, 1960

Objective: The objective of this run was to duplicate the near-steady-state portion of Run 8 .

Equipment: The equipment used during this run was the same as that used during Run 8.

Cumulative NaK Heating System Operating Data (including this run):

111 start-ups; 4148 hours above $1000^{\circ} \mathrm{F} ; 796$ hours below $1000^{\circ} \mathrm{F}$.

Run Conditions:

Bed temperature, ${ }^{\circ} \mathrm{C}$

Feed rate, I/hr

Nozzle air-to-liquid volume ratio

$80 \rightarrow 70 \rightarrow 75 \rightarrow 80$

Number of Spraying Systems Company

Type $1 / 4 \mathrm{~J}$ nozzles
Superficial fluidizing gas velocity, ft/sec

$282 \rightarrow 322 \rightarrow 300 \rightarrow 282$

Feed Composition: Aluminum nitrate,

$$
\begin{aligned}
& \text { Nitric acid, } \\
& \text { Sodium nitrate, } \\
& \text { Mercuric nitrate, } \overline{\bar{M}}
\end{aligned}
$$

0.006

Results: Even though the controllable operating variables were the same as those used during Run 8, the product properties were not duplicated during this run, apparently due to a difference in crystal structure of the product.

Difficulties: The oil-fired NaK furnace shut down for several minutes a number of times during the run. The dry fines return system frequently became plugged. Control of the feed rate was difficult at times because oil from the instrument air lines collected in the feed control instruments, causing them to become erratic. 
CALCINER Tro-poot RUN No.? 9

FEED RATE shoph $\mathrm{hr}$. BED TEMP. $500{ }^{\circ} \mathrm{C}$

NOZZLES: No. 4 TYPE $1 / 4-J$
SUPERFICIAL FLUIDIZING VELOCITY $\quad 0.78$
DRY FINES RETURN 0-9.6 AIR-TO-LIQUID VOLUME RAT1O $282 \rightarrow 322 \rightarrow 300 \rightarrow 282$

\section{scfm}

$$
\text { scfm }
$$

4

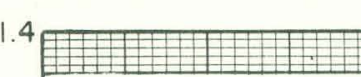

1.2 Product Bulk Density - 0

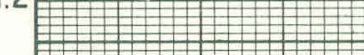
L.

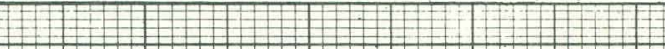

$\mathrm{Al}\left(\mathrm{NO}_{3}\right)_{3} \frac{1.95}{1.25} \mathrm{M}$

$\mathrm{HNO}_{3}$

$\mathrm{HNO}_{3} 1.25$

$\mathrm{NaNO} 3 \quad 0.089 * \mathrm{M}$ $\mathrm{Hg}\left(\mathrm{NO}_{3}\right)_{2}-0.006^{*} \mathrm{M}$

Q6 $-28,+35$ Bullk Density $-\square$

04 -

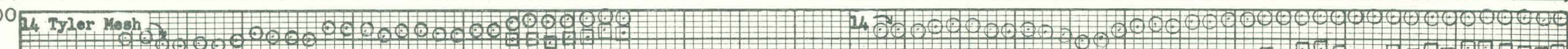

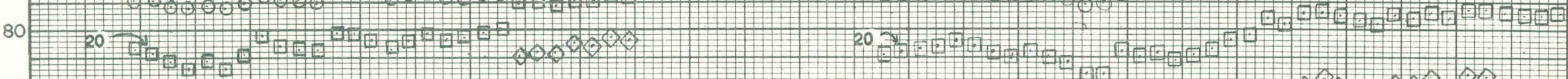

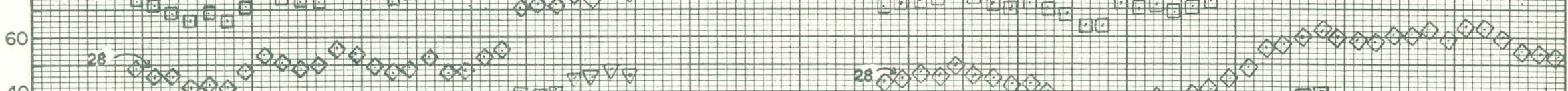

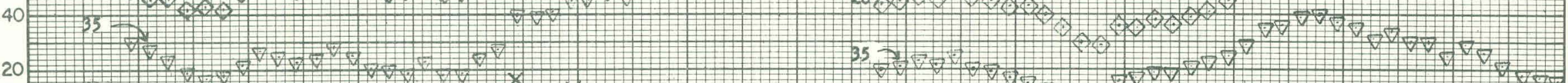

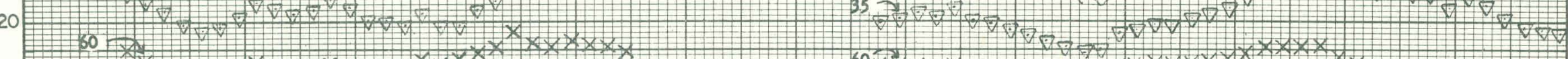

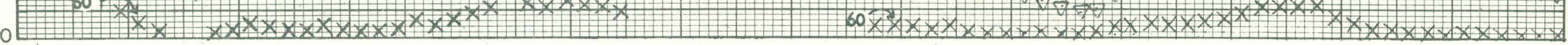

嵌

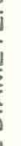

1.2

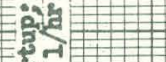

(1)
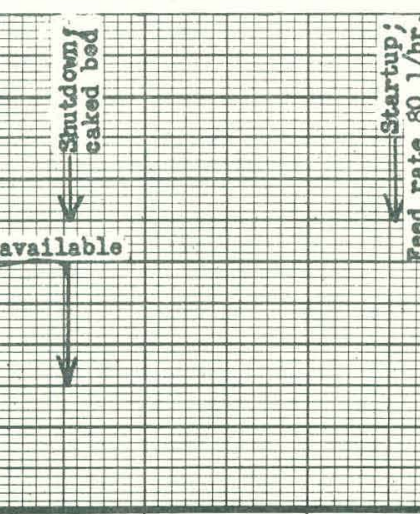

0.8

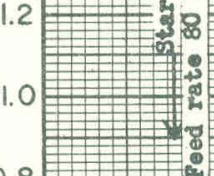

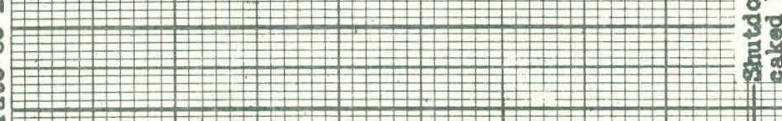

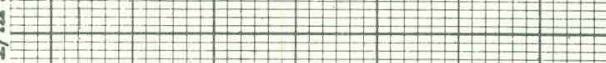

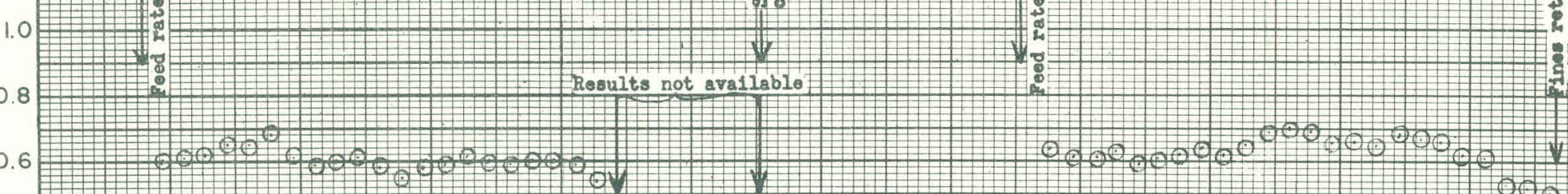

0.4

0.2

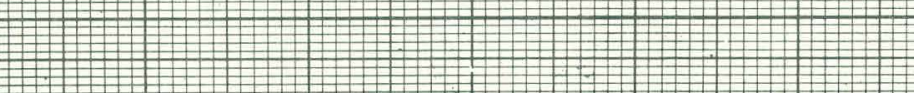

TIME -

12
$3-13$

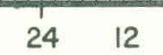

$24 \quad 12$

44

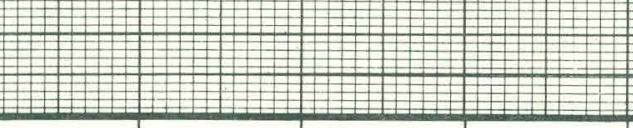

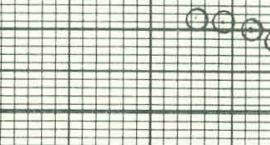

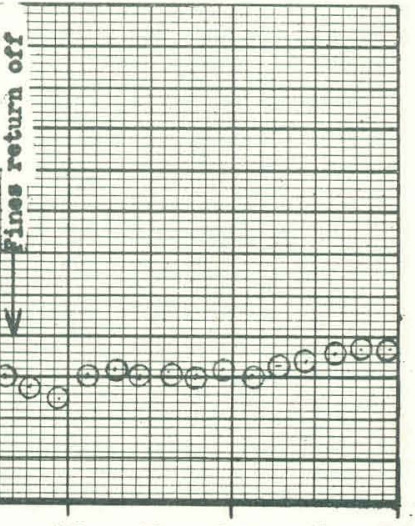

Fig. 29 Product Data, Run 9 (Sheet 1 of 3) 
CALCINER Two-foot RUN No. 9

FEED RATE $1 / \mathrm{hr}$. BED TEMP. $500{ }^{\circ} \mathrm{C}$

NOZZLES: No. 4 TYPE $1 / 4-J$
SUPERFICIAL FLUIDIZING VELOCITY $0.78 \mathrm{ft} / \mathrm{sec}$

DRY FINES RETURN $0-9.6$ scfm

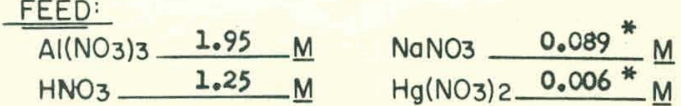

* except when 0 for periods shown

1.4 AIR-TO-LIQUID VOLUME RATIO $282 \rightarrow 322 \rightarrow 300 \rightarrow 282$

* except when 0 for periods shown

1.2

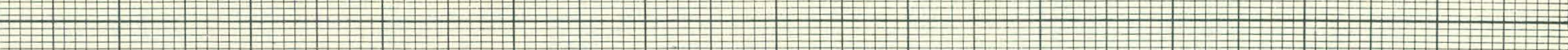

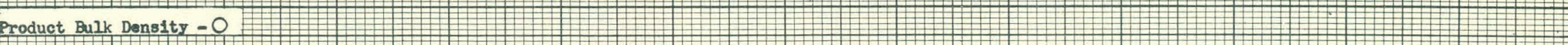

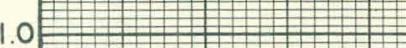

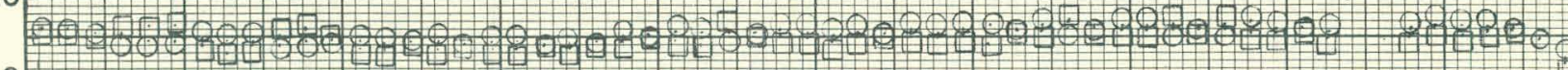

0.8

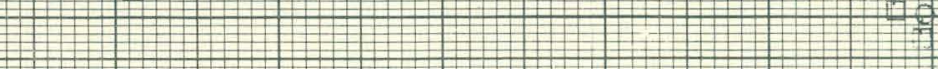

Q.6 $-28,+35$ Bulk Density $-\square$

\begin{tabular}{|l|l|}
\hline \\
\hline-1
\end{tabular}

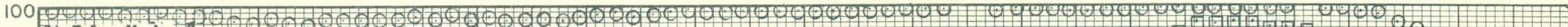

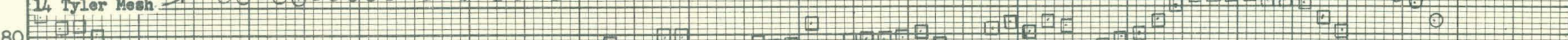

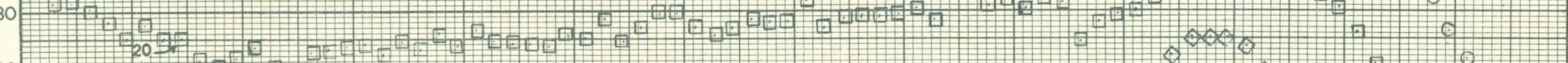

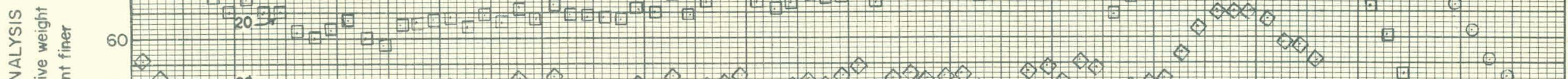

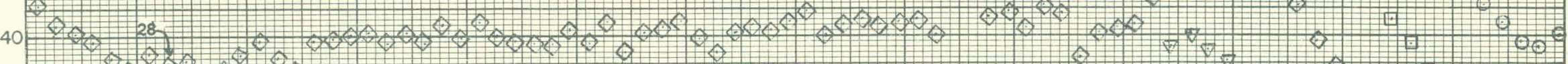

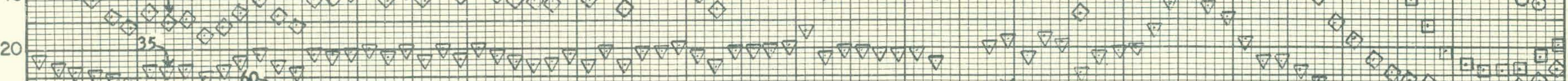

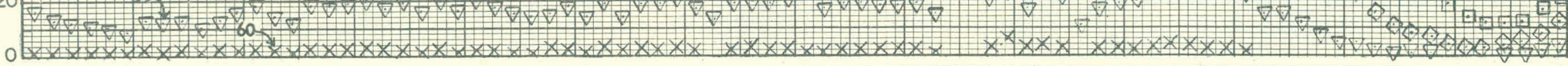

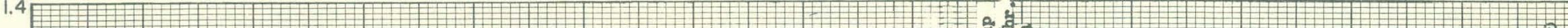

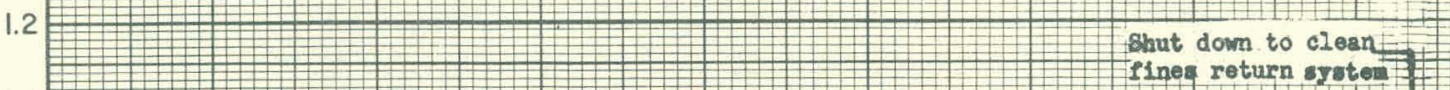

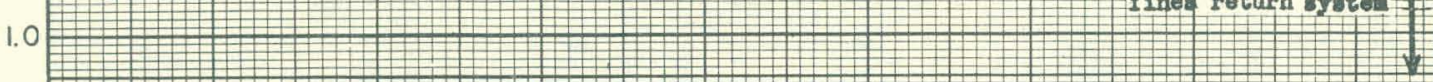

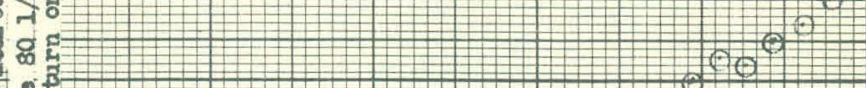

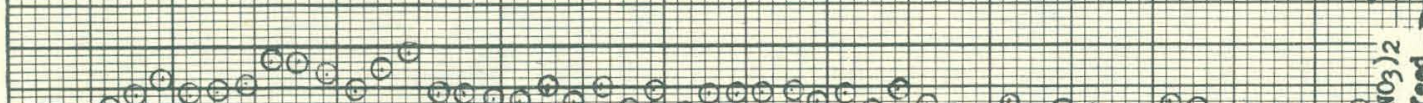

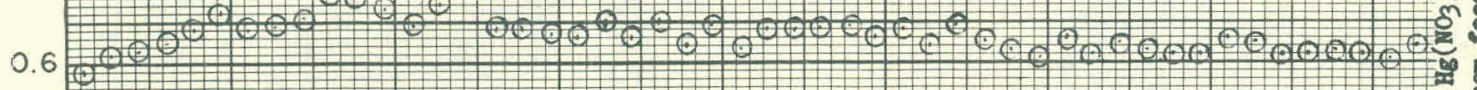

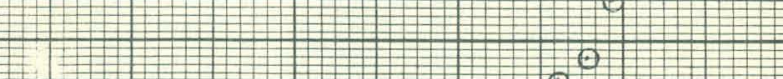

0.4

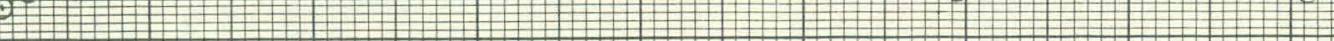

0.2

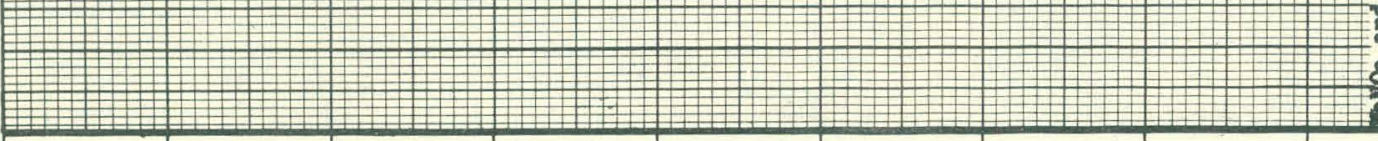

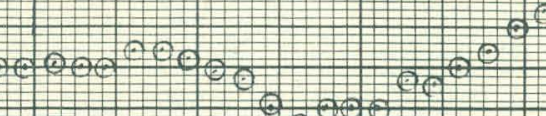

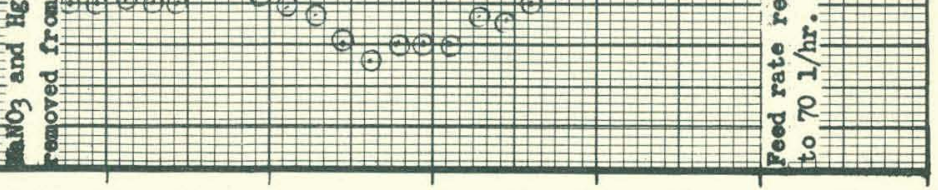

TIME -

12

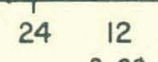

$24 \quad 12$

$24 \begin{array}{rrr}12 & 24 & 12 \\ 3-30 & & 3-31\end{array}$

$24 \quad 12$

$24 \quad 12$

$24 \quad 12$

Fig. 29

Product Data, Run 9 (Sheet 2 of 3)

CPP-S- 1570 
CALCINER Two-soot RUN No._ 9

FEED RATE shown $\mathrm{hr}$ BED TEMP $500^{\circ} \mathrm{C}$

NOZZLES: NO. 4 TYPE $1 / 4-\mathrm{J}$
SUPERFICIAL FLUIDIZING VELOCITY $0.78 \mathrm{ft} / \mathrm{sec}$

DRY FINES RETURN $0-9.6$ scfm

AIR-TO-LIQUID VOLUME RATIO $282 \rightarrow 322 \rightarrow 300 \rightarrow 282$
FEED:

$\mathrm{Al}\left(\mathrm{NO}_{3}\right)_{3}-1.95-\mathrm{M} \quad \mathrm{NaNO}_{3}-0.089^{*} \mathrm{M}$ $\mathrm{HNO}_{3} \quad \frac{1.25}{\mathrm{M}} \mathrm{Hg}\left(\mathrm{NO}_{3}\right)_{2} \mathrm{O}_{2} .006^{*} \mathrm{M}$

* areopt when $\theta$ for periods show

$1 . 4 \longdiv { 1 }$ -

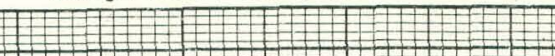

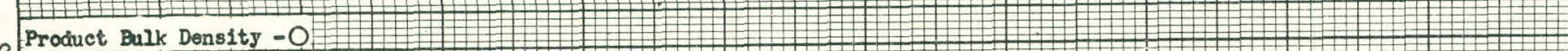

焉

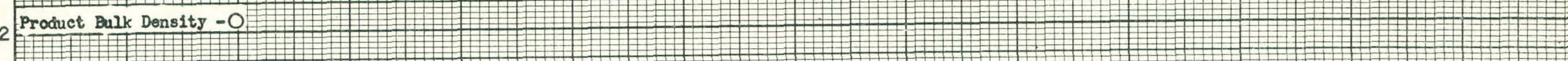

$-28,435$ Bulk Density $-\square$

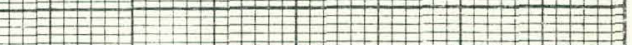

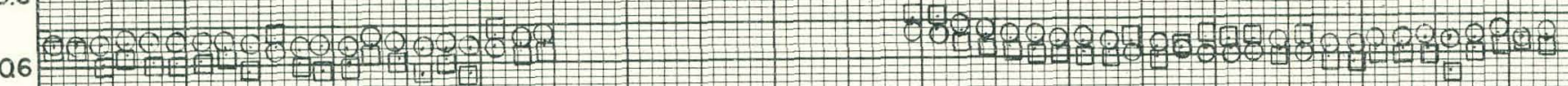

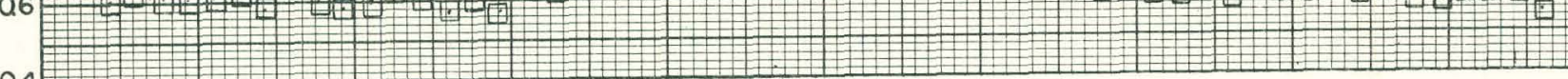

\section{.}

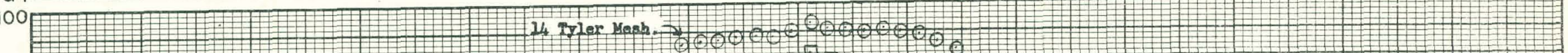

80

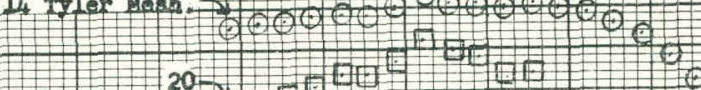

$\frac{\omega}{\sqrt{0}} \frac{5}{3}$

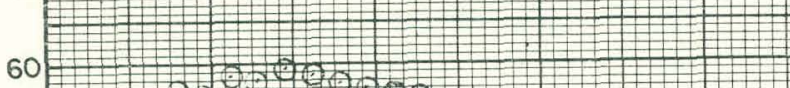
+

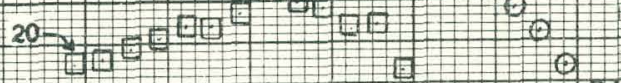

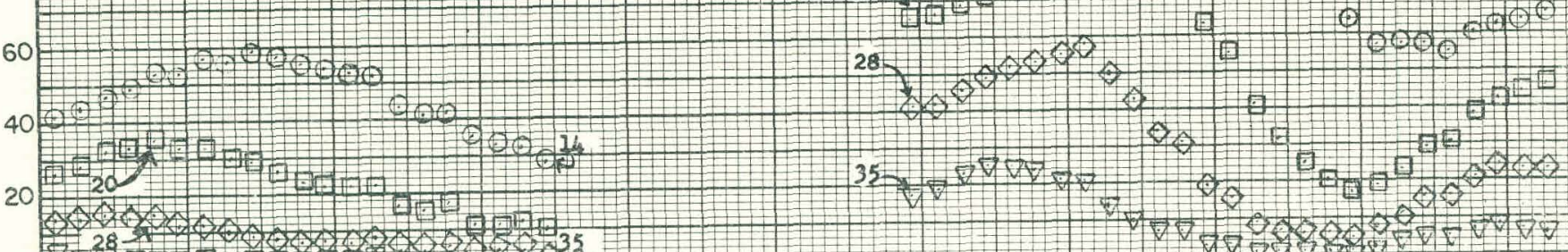

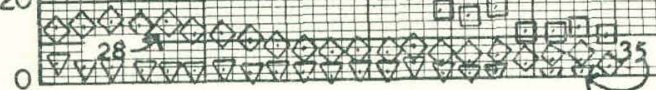

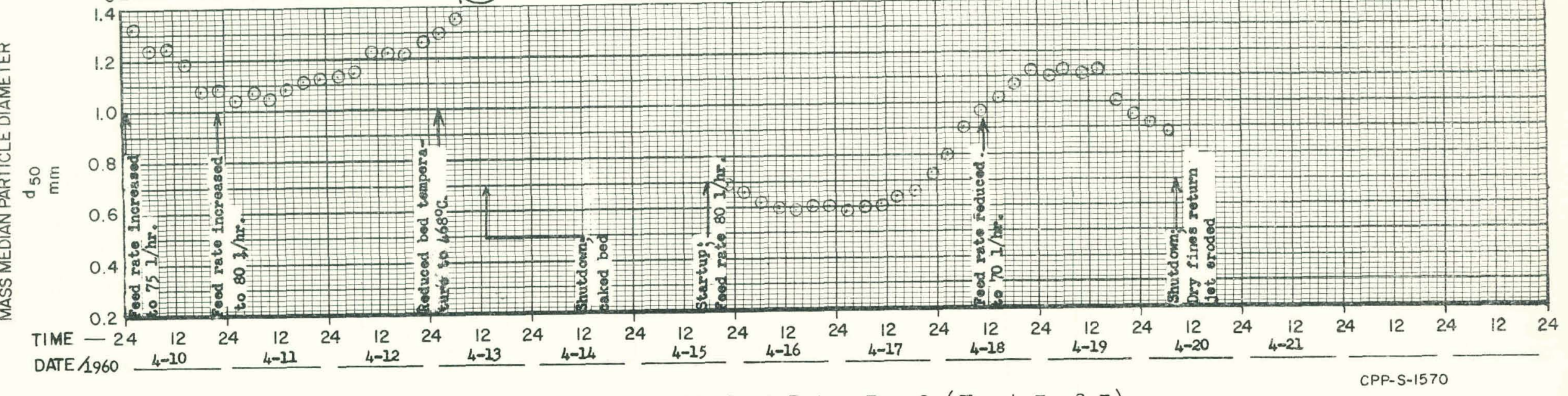

Fig. 29 Product Data, Run 9 (Sheet 3 of 3) 


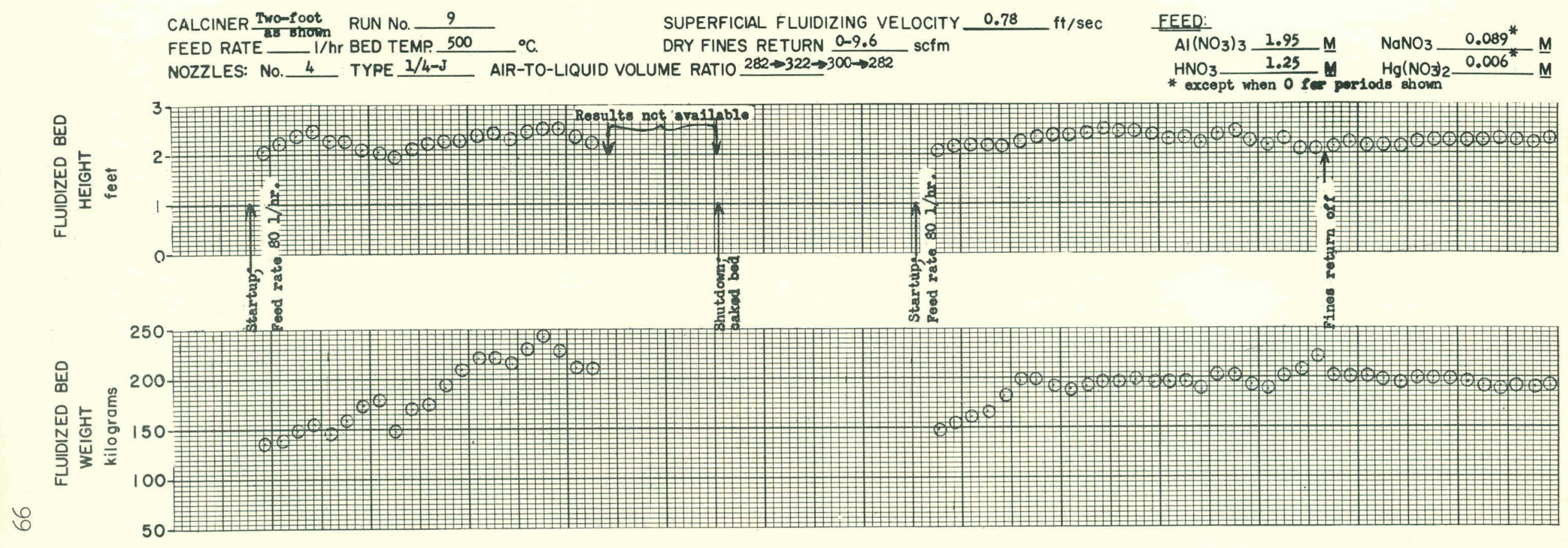

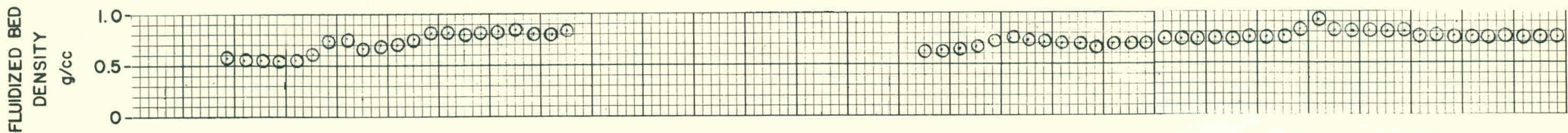

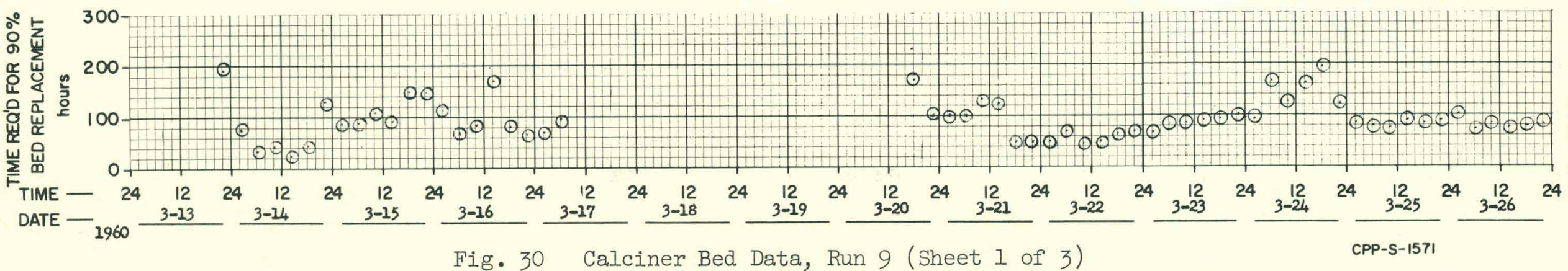


CALCINER TwO-foot RUN No. 9

FEED RATE $1 / \mathrm{hr}$ BED TEMP. 500

DRY FINES RETURN $0-9.6$

AIR-TO-LIQUID VOLUME RATIO $282 \rightarrow 322 \rightarrow 300 \rightarrow 282$

\section{scfm}

AIINO

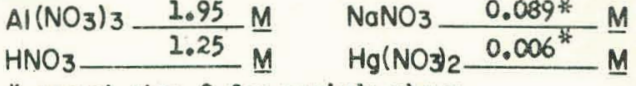

* except when 0 for periods shown

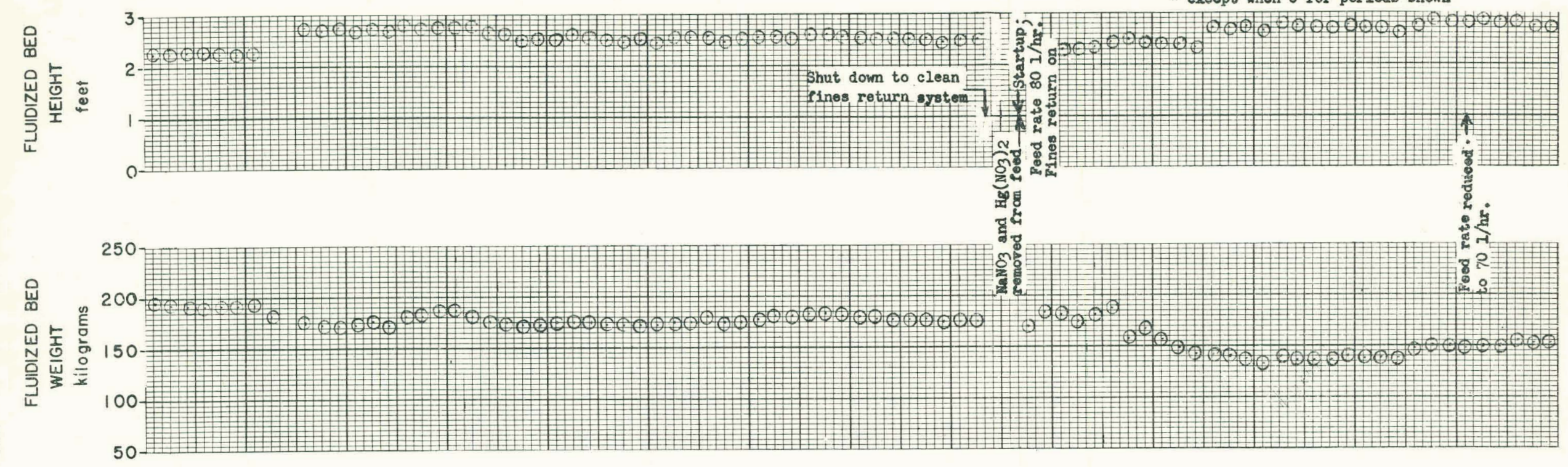

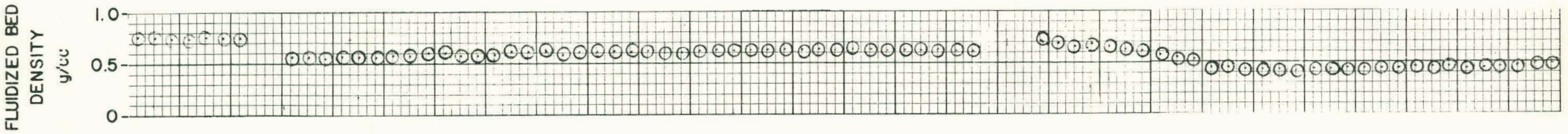

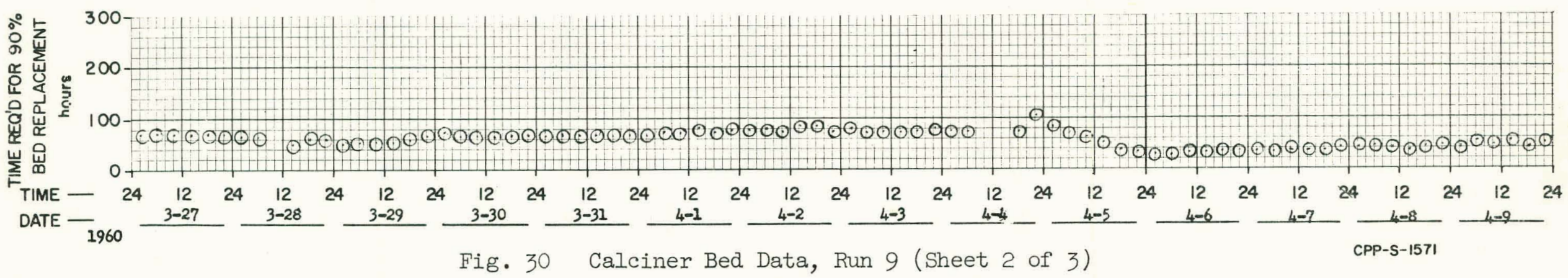

Fig. 30 Calciner Bed Data, Run 9 (Sheet 2 of 3) 

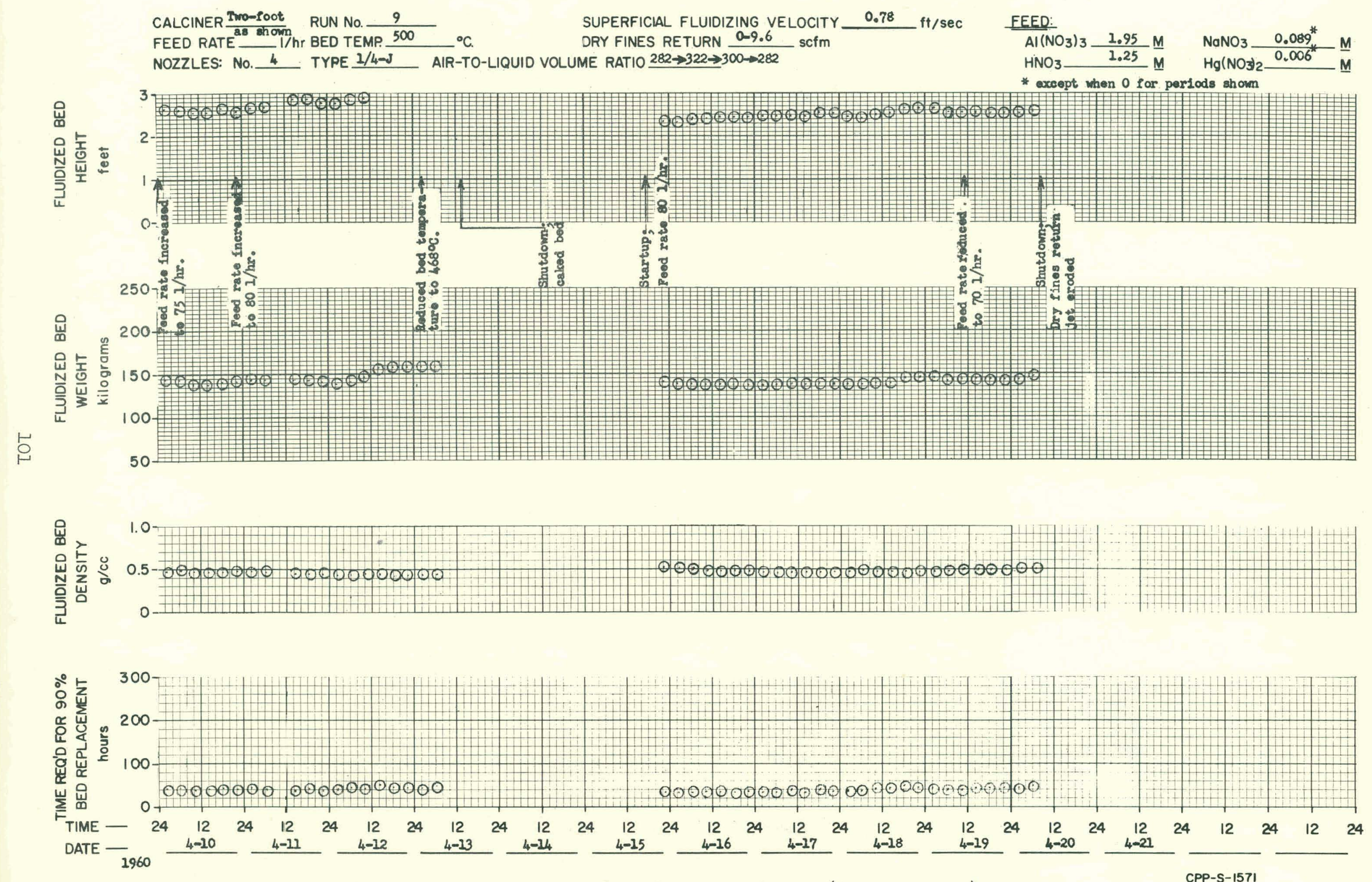

Fig. 30 Calciner Bed Data, Run 9 (Sheet 3 of 3) 


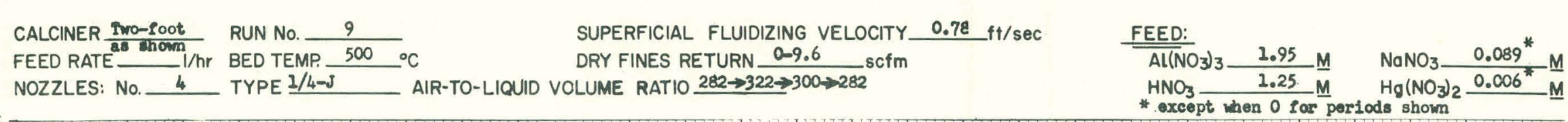
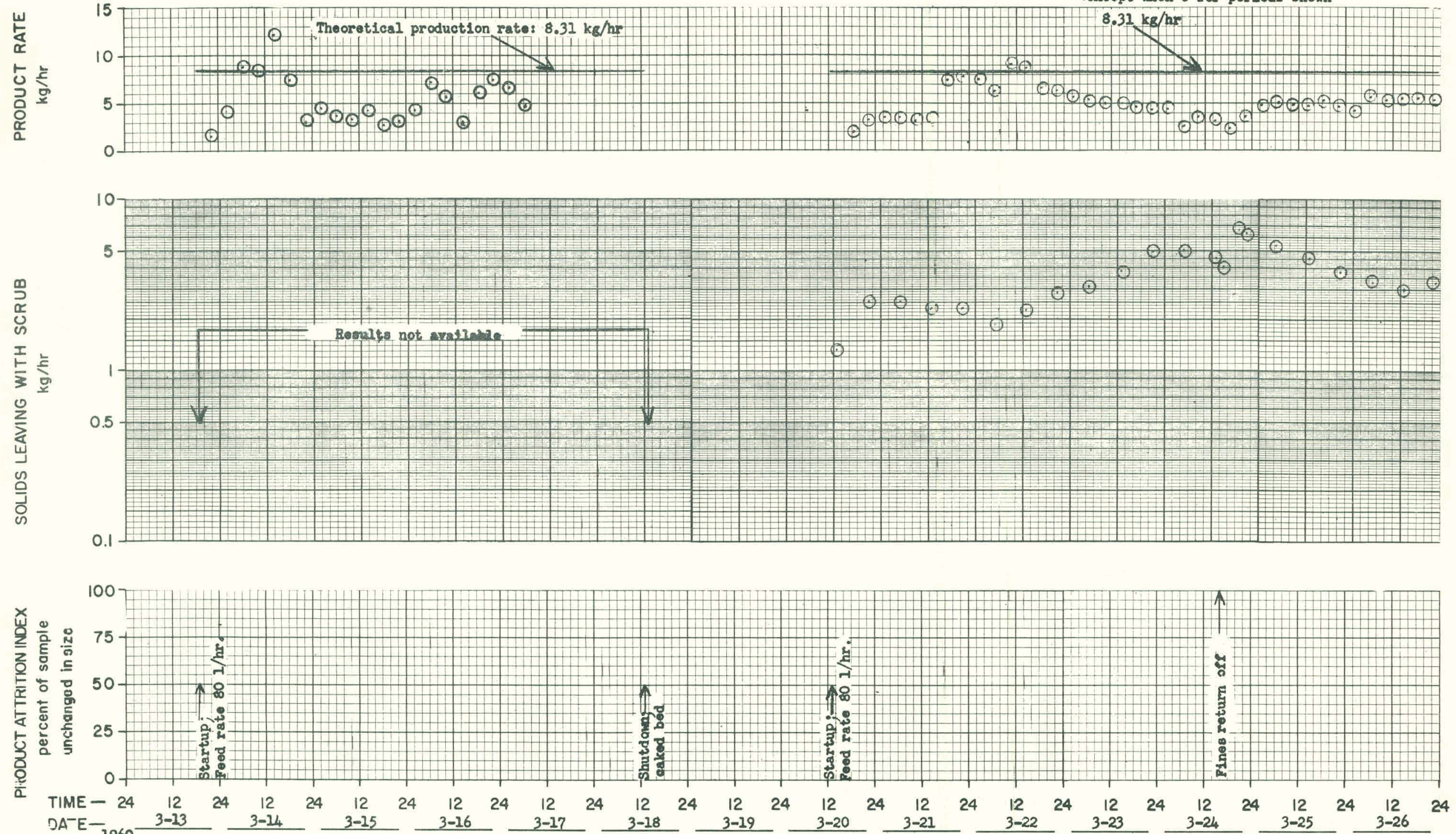

Fig. 31 General Data, Run 9 (Sheet 1 of 3)

CPP-S-1573 
CALCINER Two-foot RUN No. 9

FEED RATE $1 / \mathrm{hr}$ BED TEMP. $500{ }^{\circ} \mathrm{C}$

NOZZLES: No. 4 TYPE $1 / 4-J$
SUPERFICIAL FLUIDIZING VELOCITY $0.78 \mathrm{ft} / \mathrm{sec}$

DRY FINES RETURN $0-9.6$ scfm

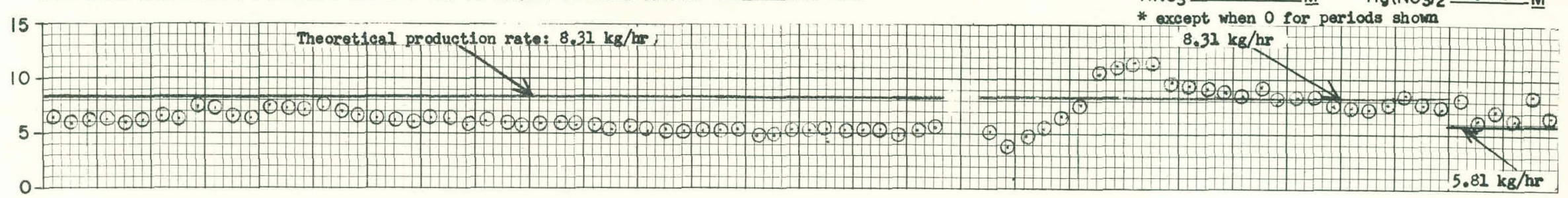

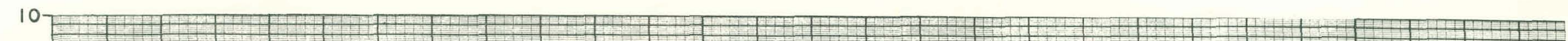

5

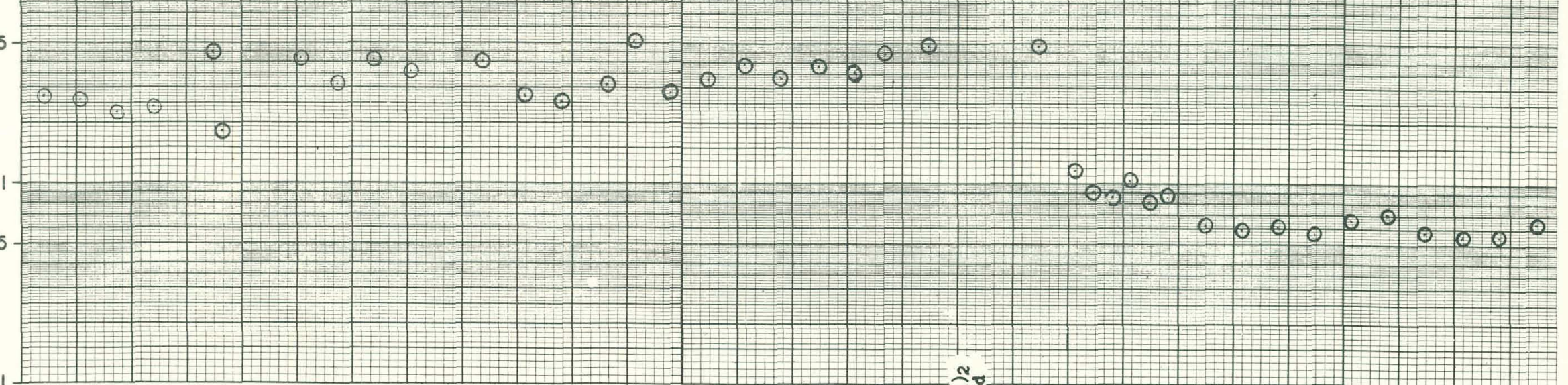

$0.1+1$ H

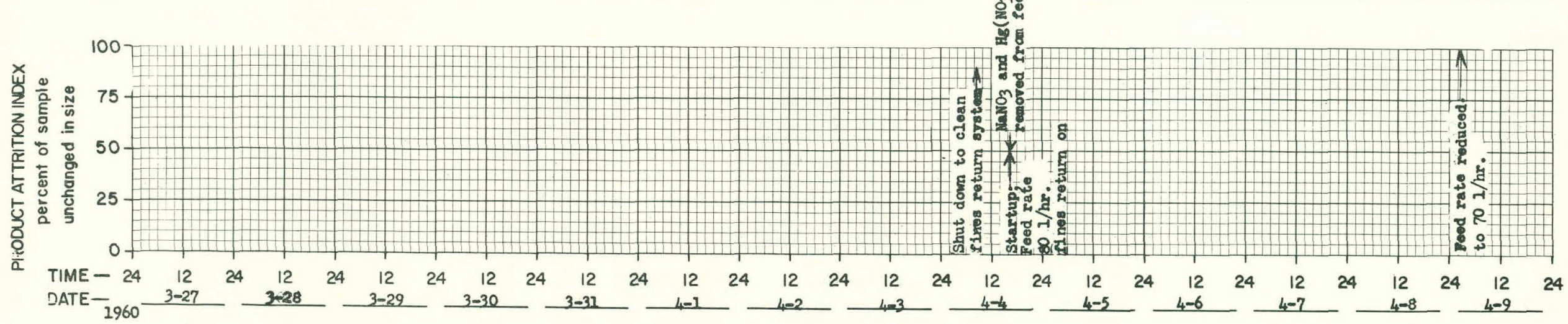

Fig. 31 General Data, Run 9 (Sheet 2 of 3)

CPP-S- 1573 
CALCINER Two-soot RUN No. ? 9

SUPERFICIAL FLUIDIZING VELOCITY $0.78 \mathrm{ft} / \mathrm{sec}$

FEED RATE 1 shown/hr BED TEMP. 500

DRY FINES RETURN $0-9.6$ scfm

NOZZLES: No. 4 TYPE $1 / 4-J$

${ }^{\circ} \mathrm{C}$
AIR-TO-LIQUID VOLUME RATIO $282 \rightarrow 322 \rightarrow 300 \rightarrow 282$
$\mathrm{Al}\left(\mathrm{NO}_{3}\right)_{3}-1.95 \mathrm{M} \quad \mathrm{NaNO}_{3} \quad 0.089 * \mathrm{M}$
$\mathrm{HNO}_{3} \quad 1.25 \mathrm{M} \quad \mathrm{Hg}\left(\mathrm{NO}_{3}\right)_{2} \mathrm{O}_{0.006 *} \mathrm{M}$

FEED:

* areept when 0 for periods shown
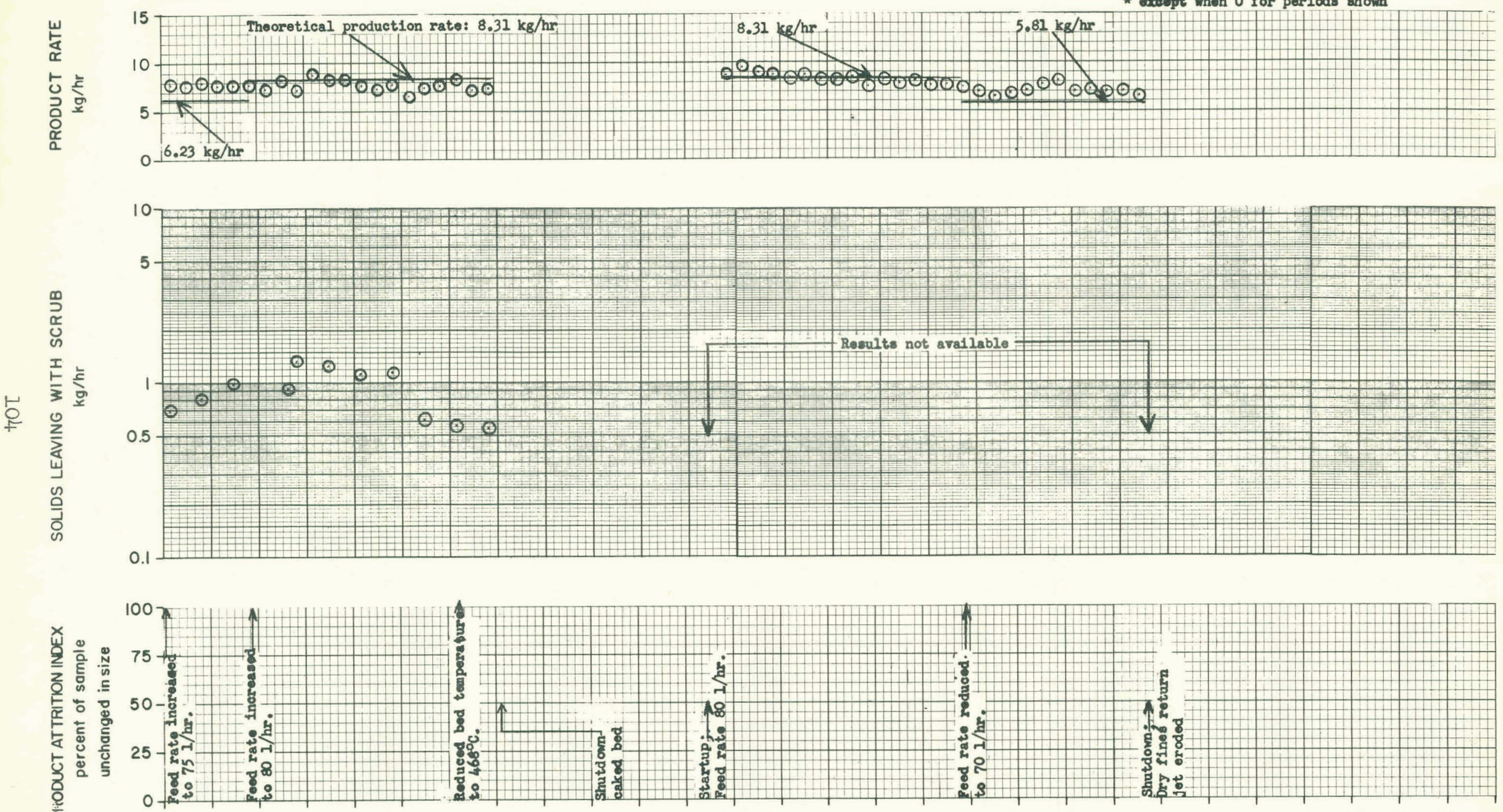

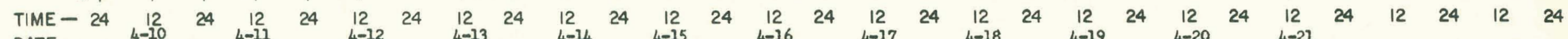
DATE- 
$\underline{\operatorname{Run} 10}$

Period Covered: From April 20, 1960 to June 8, 1960

Objective: The objective of this run was to continue attempting to duplicate the near-steady-state portion of Run 8, or, if this were impossible, to try to determine the factor or factors which prevented such duplication. Particular attention was given to the effects on the product of sodium and mercury in the feed.

Equipment: The equipment used during this run was the same as that used during Run 9.

Cumulative NaK Heating System Operating Data (including this run):

112 start-ups; 5048 hours above $1000^{\circ} \mathrm{F}$; 799 hours below $1000^{\circ} \mathrm{F}$.

$\underline{\text { Run Conditions: }}$

Bed temperature, ${ }^{\circ} \mathrm{C}$

Feed rate, $1 / \mathrm{hr}$

Nozzle air-to-liquid volume ratio

Number of Spraying Systems Company

Type $1 / 4 \mathrm{~J}$ nozzles 4

Superficial fluidizing gas velocity, ft/sec 0.78

Dry fines return

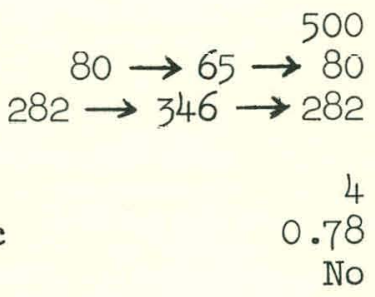

Feed Composition:

$\begin{array}{ll}\text { Aluminum nitrate, } \bar{M} & 1.95 \\ \text { Nitric acid, } & \bar{M} \\ \text { Sodium nitrate, } \bar{M} & 1.25 \\ \text { Mercuric nitrate, } \bar{M} & 0.089 \\ & 0.006\end{array}$

Results: The major objective was not realized, but it was found that the relative abundance of the two different alumina phases, amorphous and alpha, could vary considerably without changing the operating conditions; these alumina phases have entirely different physical properties. Reasons for the product alumina changes from one phase into the other were not isolated. A continuous, voluntarily terminated, trouble-free period of operation of 43 days was achieved.

Difficulties: The dry fines returm jet was replaced with a spare oversized one; however, it did not perform satisfactorily becanse insufficient high-pressure air was available. During this run, fewer equipment difficulties were encountered than in any previous mun. 
CALCINER Two-foot RUN No. 10

FEED RATE $80,65 \mathrm{l} / \mathrm{hr}$. BED TEMP. $500{ }^{\circ} \mathrm{C}$

NOZZLES: No 4 TYPE $1 / 4 \mathrm{~J}$

AIR-TO-LIQUID VOLUME RATIO 282:346
SUPERFICIAL FLUIDIZING VELOCITY $0.78 \mathrm{ft} / \mathrm{sec}$

DRY FINES RETURN None - scfm
FEED:

$\operatorname{Al}\left(\mathrm{NO}_{3}\right)_{3} \frac{1.95}{1.25} \mathrm{M}$

$\mathrm{HNO}_{3}$
NaNO3 $\frac{0.089}{-M}$

$\mathrm{Hg}\left(\mathrm{NO}_{3}\right)_{2} \stackrel{0.006}{-\mathrm{M}}$

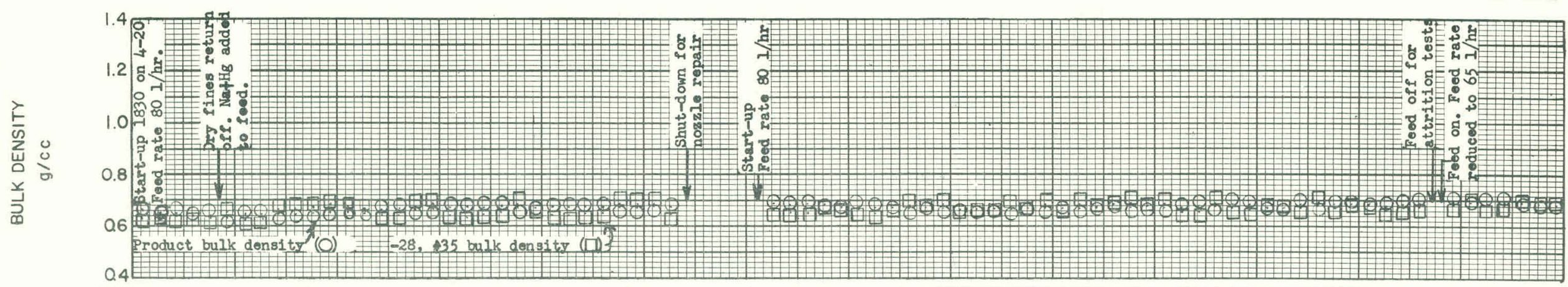

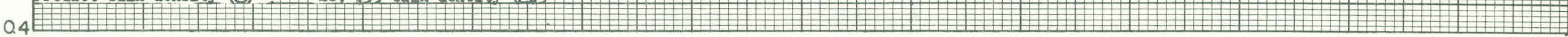

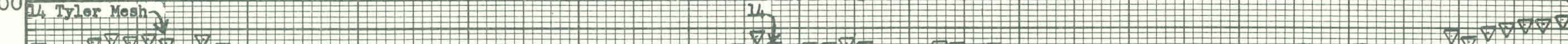

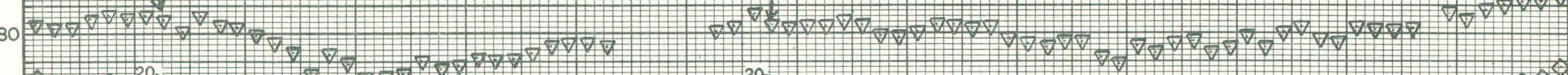

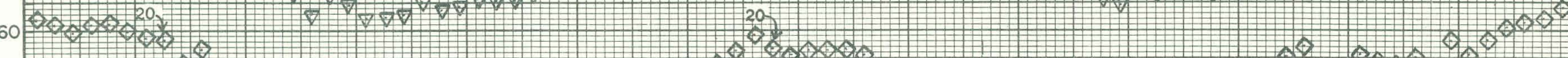

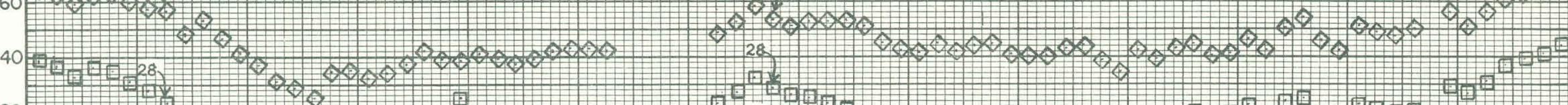

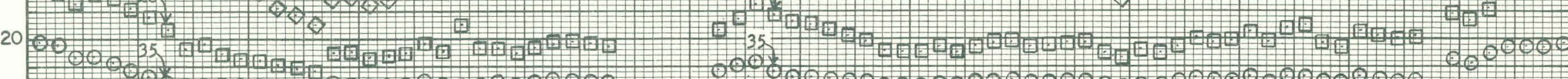

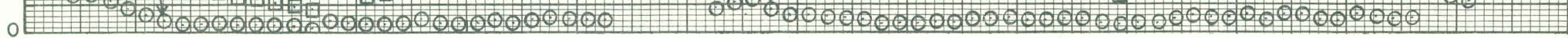

虫

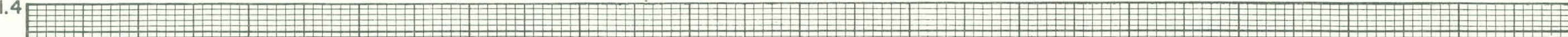

1.2

1.0

8

$\overbrace{0}^{\circ} E$

0.6

0.4 0.2

TIME -24

DATE $/ 1960 \quad 4-21$

$\begin{array}{llll}24 & 12 & 24\end{array}$

$24 \underset{4-23}{12}$

$24 \begin{array}{cccc}12 \\ 4-24\end{array} \quad 24 \begin{gathered}12 \\ 4-25\end{gathered} \quad 24 \begin{gathered}12 \\ 4-26\end{gathered}$

Fig. 32

Product Data, Run 10 (Sheet 1 of 4 )

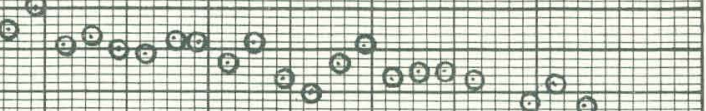
10000000000

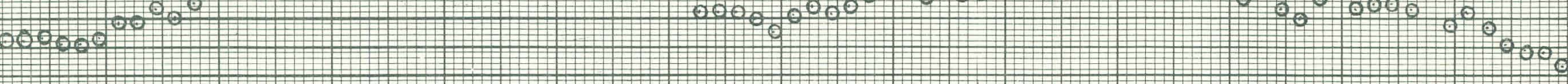

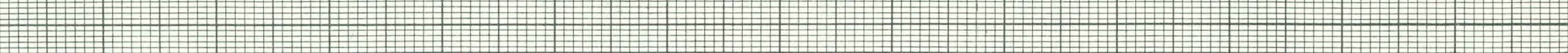

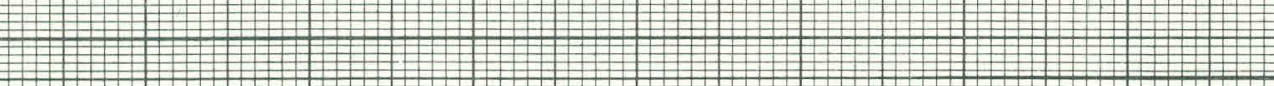

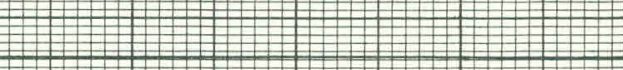


CALCINER Two-foot RUN No 10

FEED RATE $80,65 \mathrm{l} / \mathrm{hr}$. BED TEMP. $500{ }^{\circ} \mathrm{C}$

NOZZLES: No. 4 TYPE $1 / 4 \mathrm{~J}$
SUPERFICIAL FLUIDIZING VELOCITY

DRY FINES RETURN_None scfm
0.78 AIR-TO-LIQUIO VOLUME RATIO 2823346
FEED:

$\mathrm{Al}\left(\mathrm{NO}_{3}\right)_{3} \quad 2.95 \mathrm{M}$

$\mathrm{HNO}_{3}$
$\mathrm{NaNO}_{3}-0.089$ M

$\mathrm{Hg}\left(\mathrm{NO}_{3}\right)_{2}$

竞。

\begin{tabular}{l}
1.4 \\
\hline
\end{tabular}

1.2 -

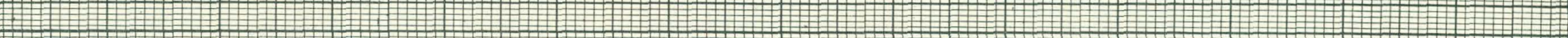

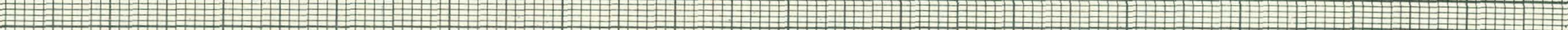

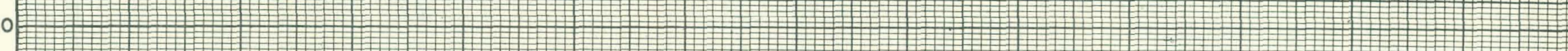

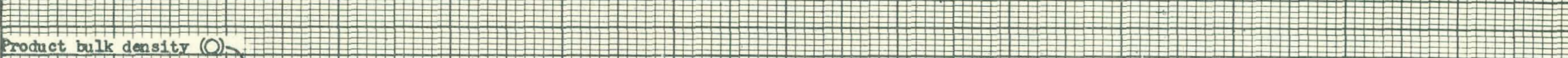

0.8 Product bulk densith $(0)$ ב

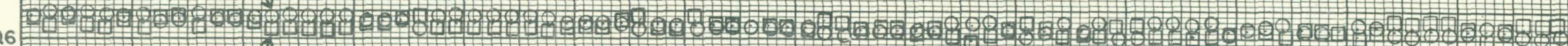

28.235 bulk density (D) (

0.4 ב

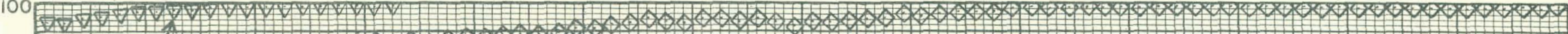

Tyler Moghs

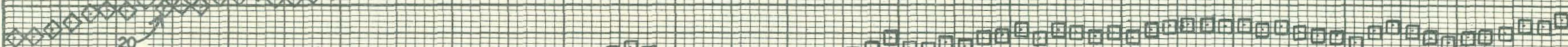

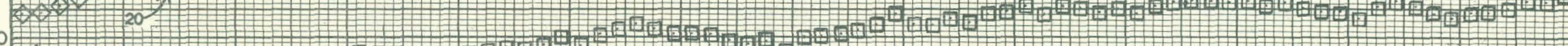
60 = (5) 40 再

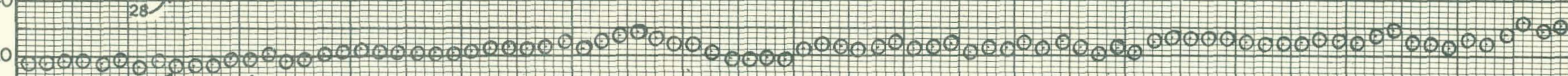

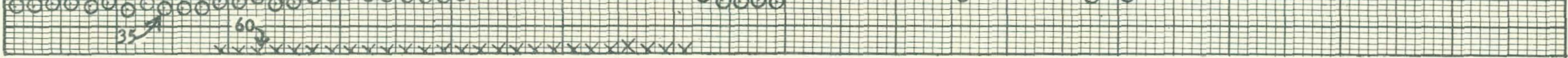

${ }^{1.4}$ ( (2)

○ (2)

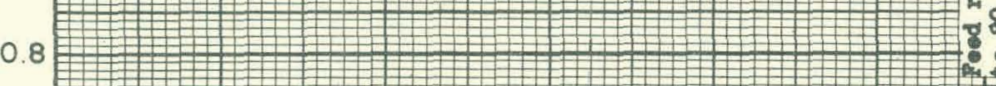

0.4

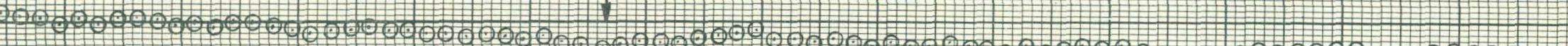
_

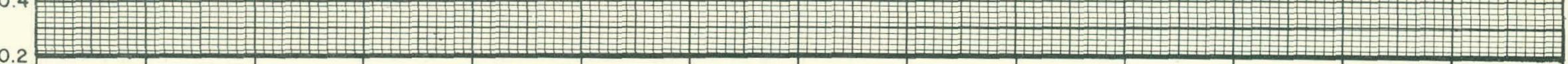
TIME $\begin{array}{lllllllllllllllllllllllllllllllllllll}-24 & 12 & 24 & 12 & 24 & 12 & 24 & 12 & 24 & 12 & 24 & 12 & 24 & 12 & 24 & 12 & 24 & 12 & 24 & 12 & 24 & 12 & 24 & 12 & 24 & 12 & 24 & 12 & 24\end{array}$ DATE $/ 1960-5-5 \quad 5-6 \quad 5-7 \quad 5-8 \quad 5-9 \quad 5-10 \quad 5-11 \quad 5-12 \quad 5-13 \quad 5-14 \quad 5-15 \quad-5-16 \quad 5-17 \quad 5-18$

Fig. 32 Product Data, Run 10 (Sheet 2 of 4)

CPP-S-1570 
CALCINER Two-foot RUN No. 10

FEED RATE $80,65 \mathrm{l} / \mathrm{hr}$. BED TEMP $500{ }^{\circ} \mathrm{C}$

NOZZLES: No. 4

TYPE $1 / 4 \mathrm{~J}$
SUPERFICIAL FLUIDIZING VELOCITY 0.78

DRY FINES RETURN_None_ $s c f m$

AIR-TO-LIQUID VOLUME RATIO 282;346
FEED:

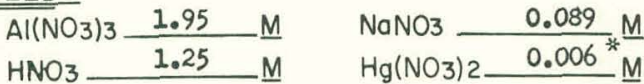

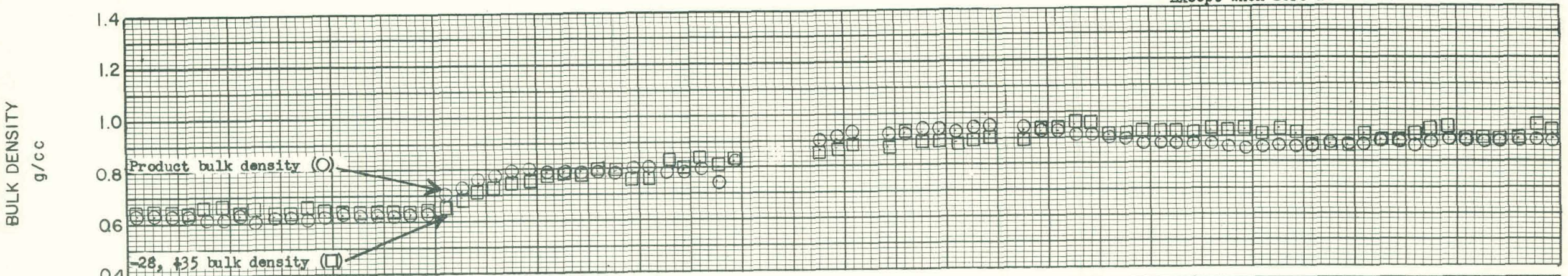

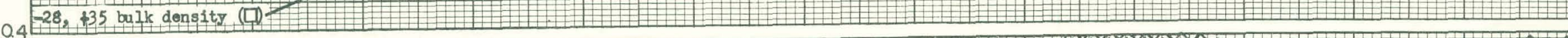

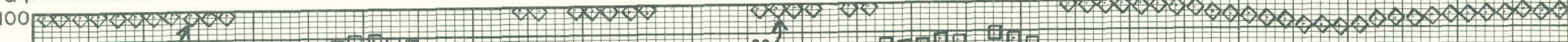

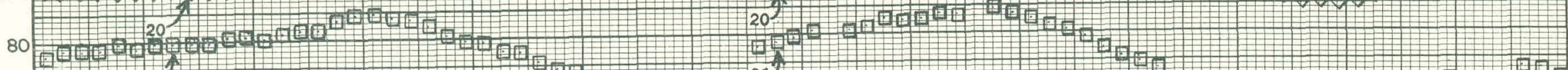

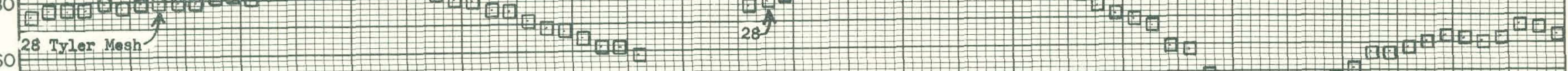

40

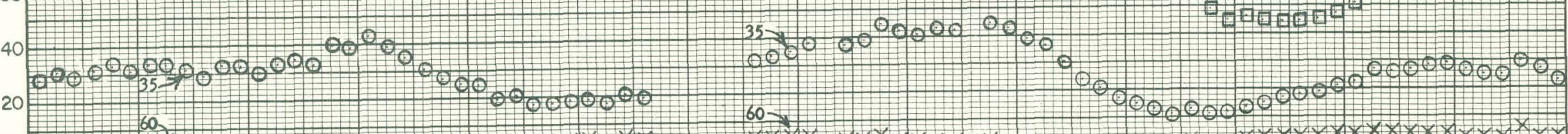

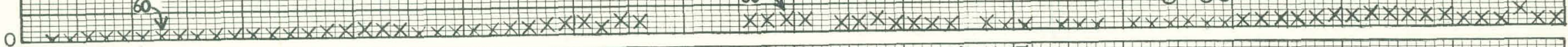

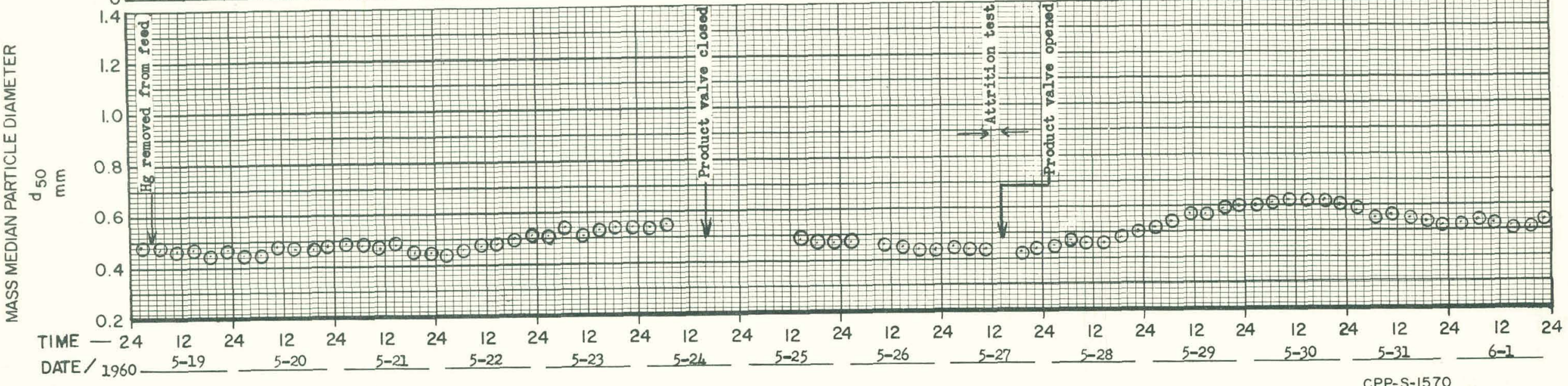

Fig. 32 Product Data, Run 10 (Sheet 3 of 4) 
CALCINER Two-Poot RUN No. $\frac{10}{500{ }^{\circ} \mathrm{C}}$

$500{ }^{\circ} \mathrm{C}$ DR'Y FINES RETURN None $\mathrm{scfm}$
SUPERFICIAL FLUIDIZING VELOCITY 0.78 ft/sec.
FEED:

$\left.\left.\mathrm{Al}^{(N O}\right)_{3}\right)_{3} \quad 1.95-\mathrm{M} . \quad \mathrm{NaNO}_{3}-0.089$ M

$\mathrm{HNO}_{3} 1.25 \mathrm{M}$

* Except when zero as noted.
$\mathrm{Hg}\left(\mathrm{NO}_{3}\right)_{2} \stackrel{0.006 *}{-\mathrm{M}}$

NOZZLES: NO. 4 TYPE $1 / 4 \mathrm{~J}$ AIR-TO-LIQUID VOLUME RATIO $282: 346$

范。

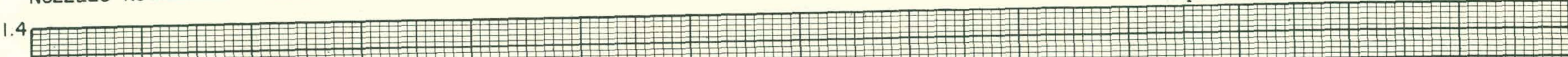
\begin{tabular}{rl|l|}
\hline \\
\hline
\end{tabular}

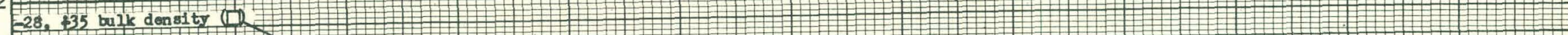
(1) (a)

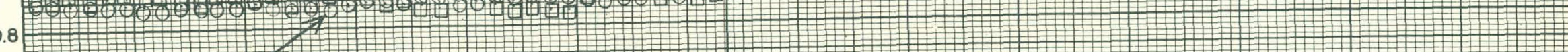

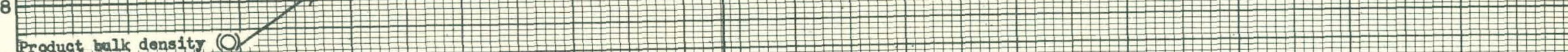

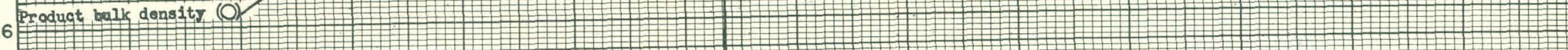

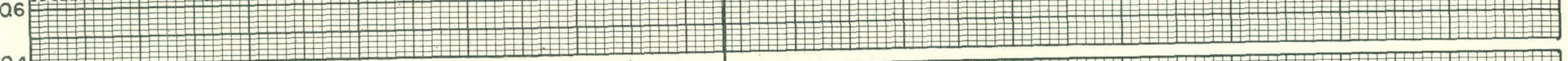

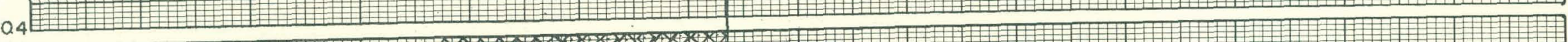

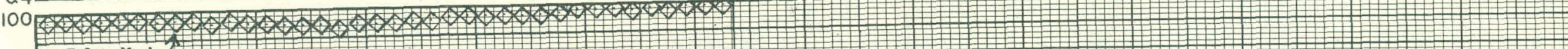
80 20 Triar Megh \begin{tabular}{lll}
\hline &
\end{tabular}

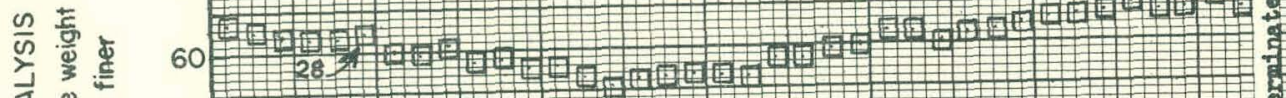

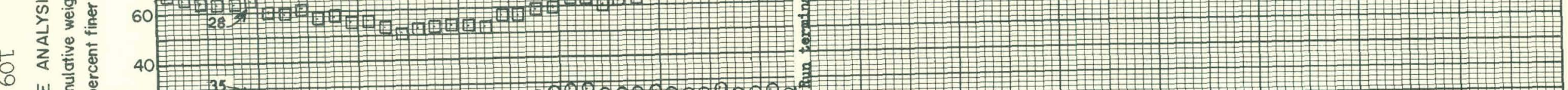

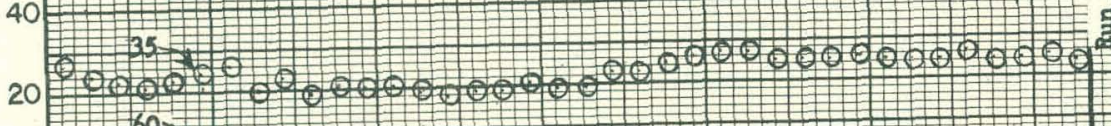
60 (1)

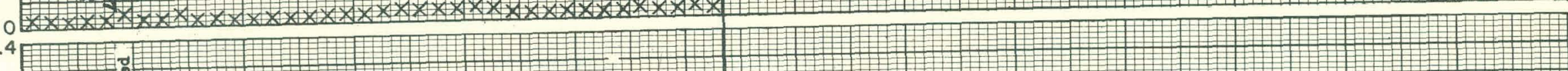

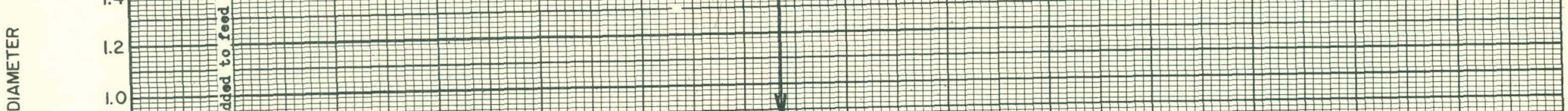

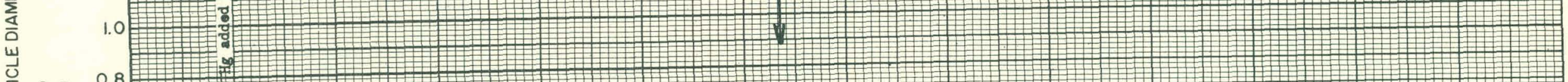

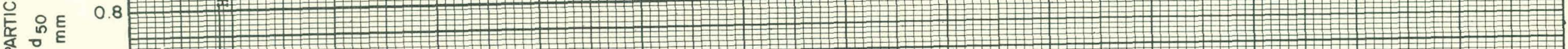

2

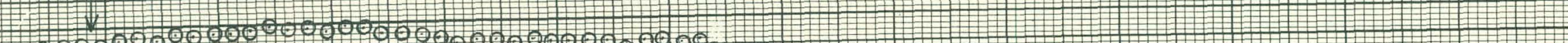

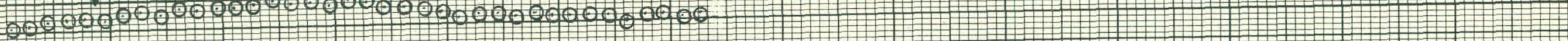

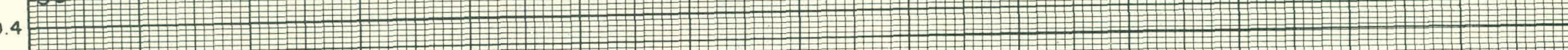

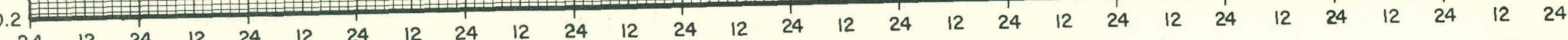
TIME - 24 DATE $/ 1960$

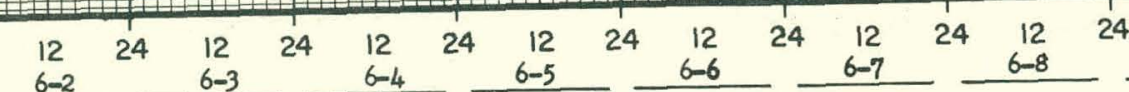

$$
\text { Fig. } 32 \text { Product Data, Run } 10 \text { (Sheet } 4 \text { of } 4 \text { ) }
$$$$
\text { CPP-S-1570 }
$$ 
CALCINER Two-foot RUN No 10

FEED RATE $80,65 \mathrm{l} / \mathrm{hr}$ BED TEMP $500{ }^{\circ} \mathrm{C}$

NOZZLES: No. 4 TYPE $1 / 4 \mathrm{~J}$
SUPERFICIAL FLUIDIZING VELOCITY $0.78 \quad \mathrm{t} / \mathrm{sec}$

DRY FINES RETURN None scfm
FEED:

$\mathrm{Al}\left(\mathrm{NO}_{3}\right)_{3}-1.95 \mathrm{M}$

$\mathrm{HNO}_{3}$
$\mathrm{NaNO}_{3}-0.089 \mathrm{M}$

$\mathrm{Hg}\left(\mathrm{NO}_{3}\right)_{2} 0.006 \mathrm{M}$
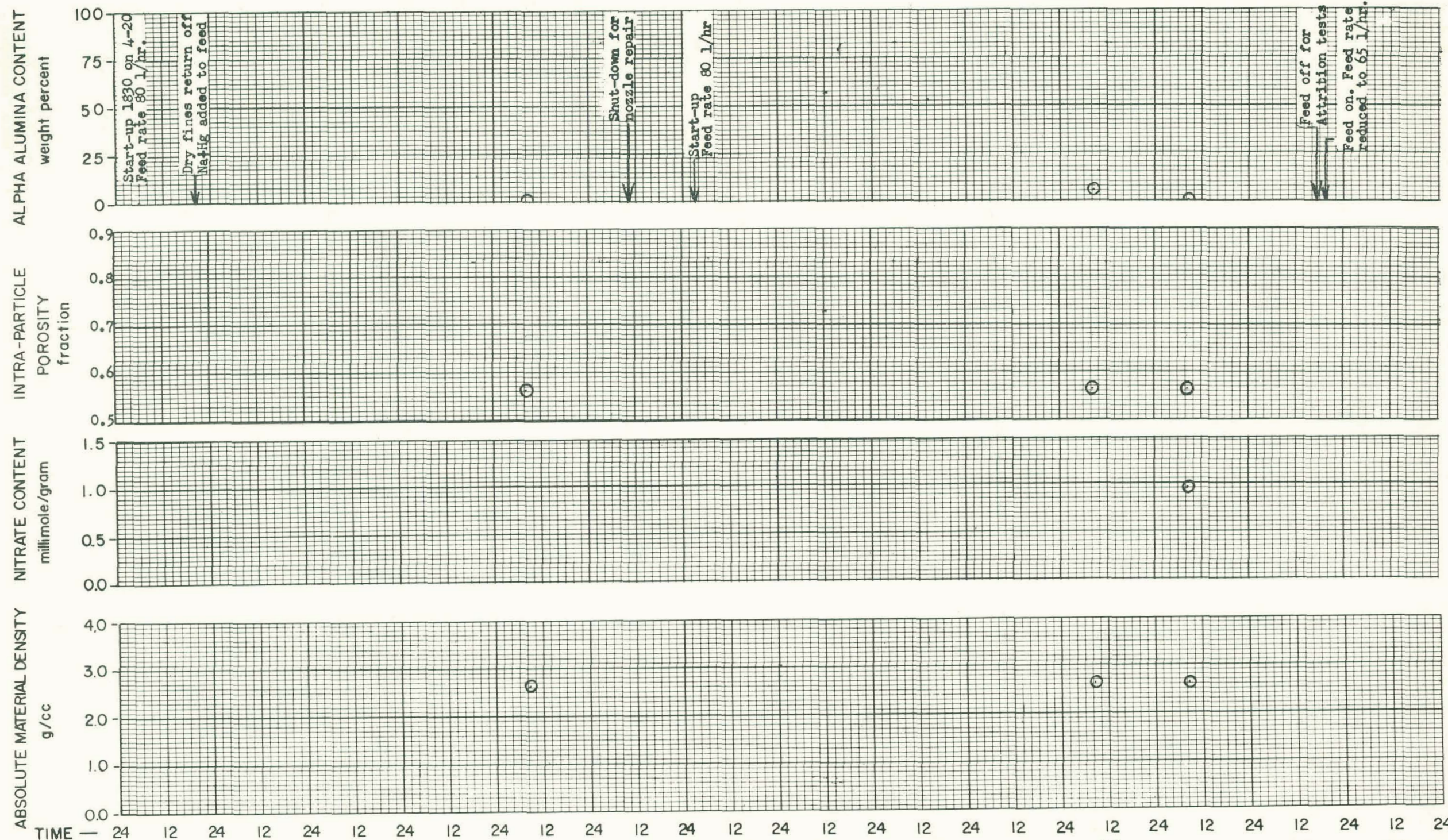

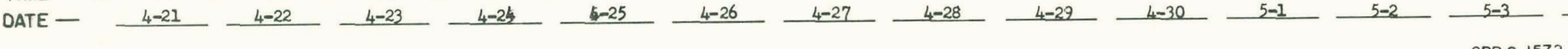

Fig. 33 Additional Product Data, Run 10 (Sheet 1 of 4) 
CALCINER Two-foot RUN No 10

FEED RATE $80,65 \mathrm{l} / \mathrm{hr}$ BED TEMP. $500{ }^{\circ} \mathrm{C}$
SUPERFICIAL FLUIDIZING VELOCITY $0.78 \mathrm{ft} / \mathrm{sec}$

DRY FINES RETURN _ NON

AIR-TO-LIQUIO VOLUME RATIO $282: 346$
FEED:

$\overline{\mathrm{Al}\left(\mathrm{NO}_{3}\right)_{3}} \frac{1.95}{3.25} \mathrm{M} \quad \mathrm{NaNO}_{3} \frac{0.089}{\mathrm{M}}$
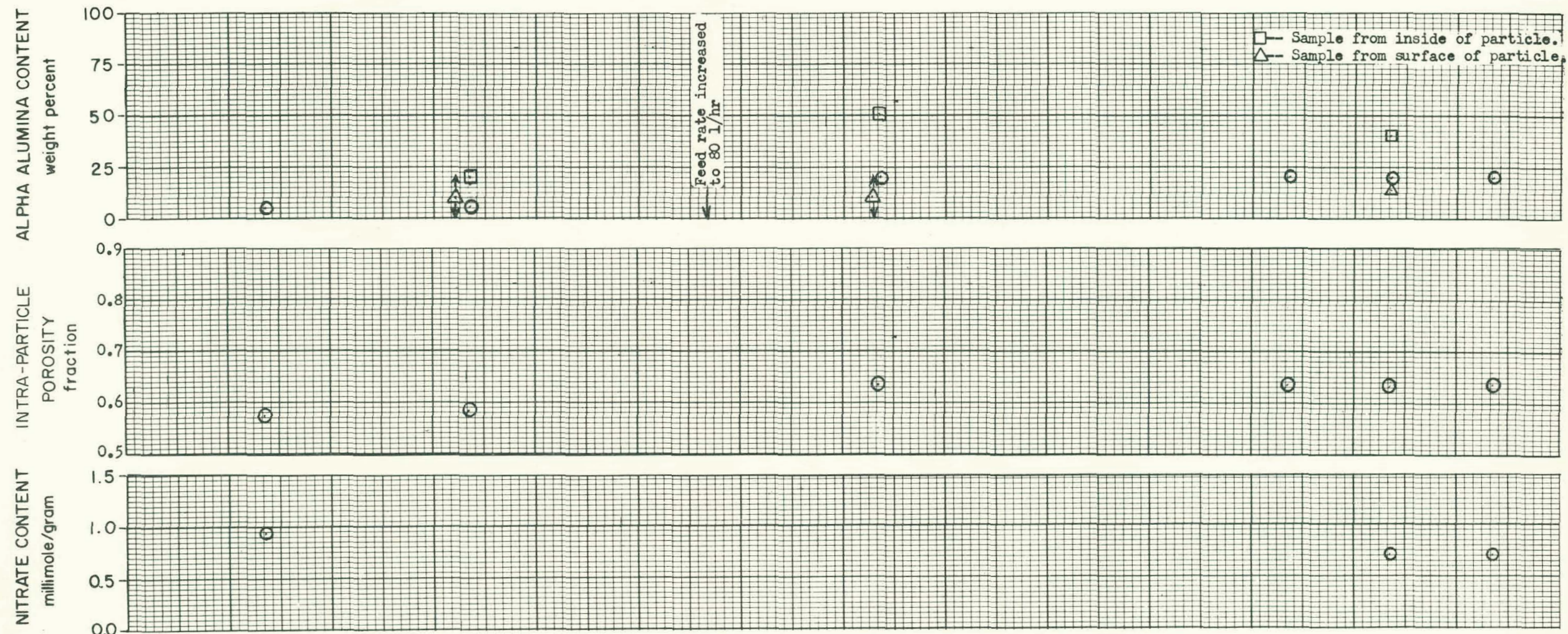

占

4.0

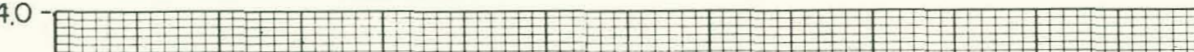

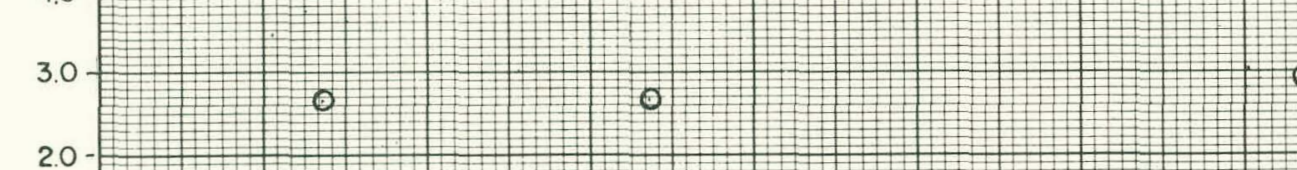

or

1.0

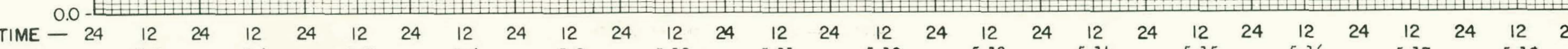

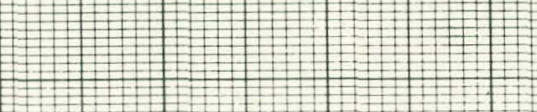

DATE $5-6$ 
CALCINER Two-foot RUN No. $10 \quad$ SUPERFICIAL FLUIDIZING VELOCITY $0.78 \mathrm{f} / \mathrm{seC}$

FEED RATE $80,65 \mathrm{l} / \mathrm{hr}$ BED TEMP. $500{ }^{\circ} \mathrm{C}$ DRY FINES RETURN None scfm

NOZZLES: NO. 4 TYPE $1 / 4 \mathrm{~J}$ AIR-TO-LIQUID VOLUME RATIO $282 ; 346$
FEED:

$\overline{A l}\left(\mathrm{NO}_{3}\right)_{3}-1.95 \mathrm{M} \quad \mathrm{NaNO}_{3}-0.089 \mathrm{M}$ $\mathrm{HNO}_{3}-\frac{1.25}{M} \quad \mathrm{Hg}\left(\mathrm{NO}_{3}\right)_{2}-0.006^{36}$ * Except when zero as noted.

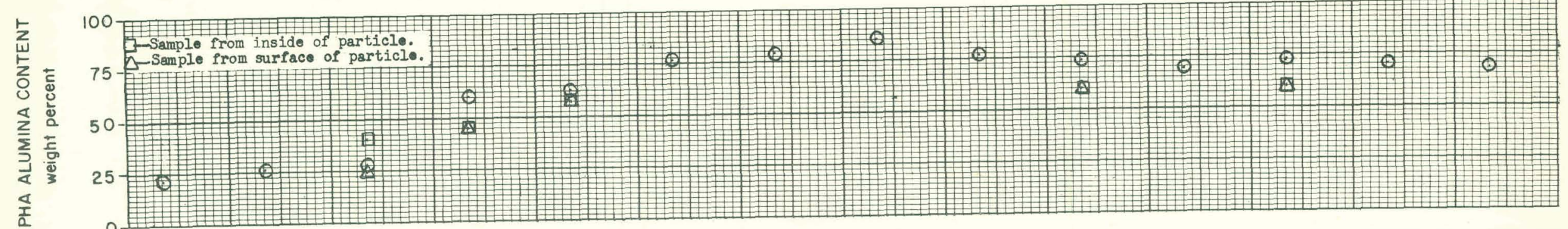

$\frac{\frac{1}{2}}{\frac{1}{\alpha}}$

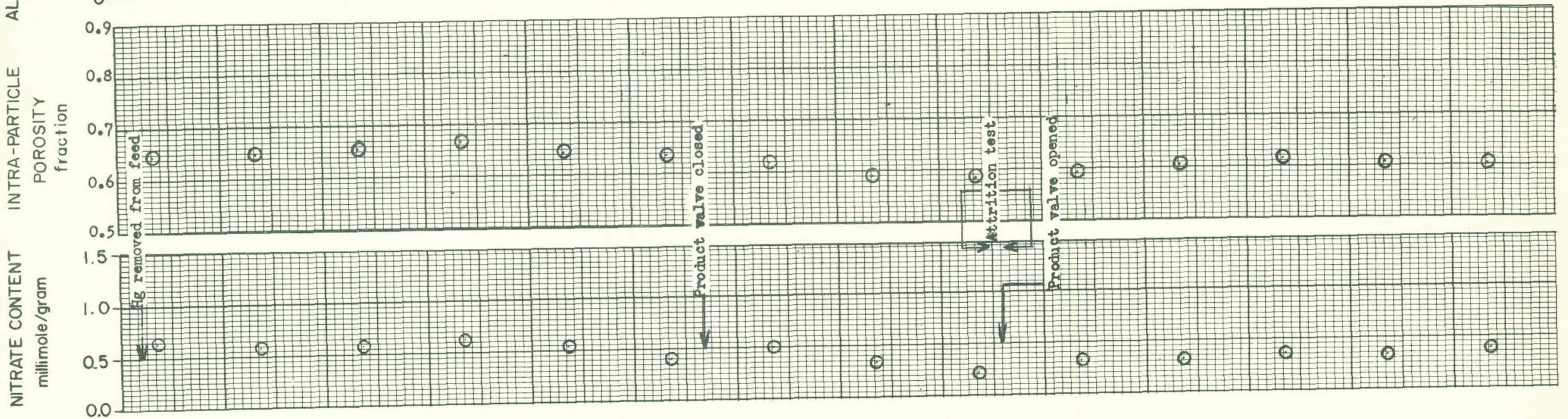

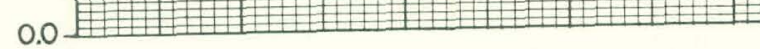

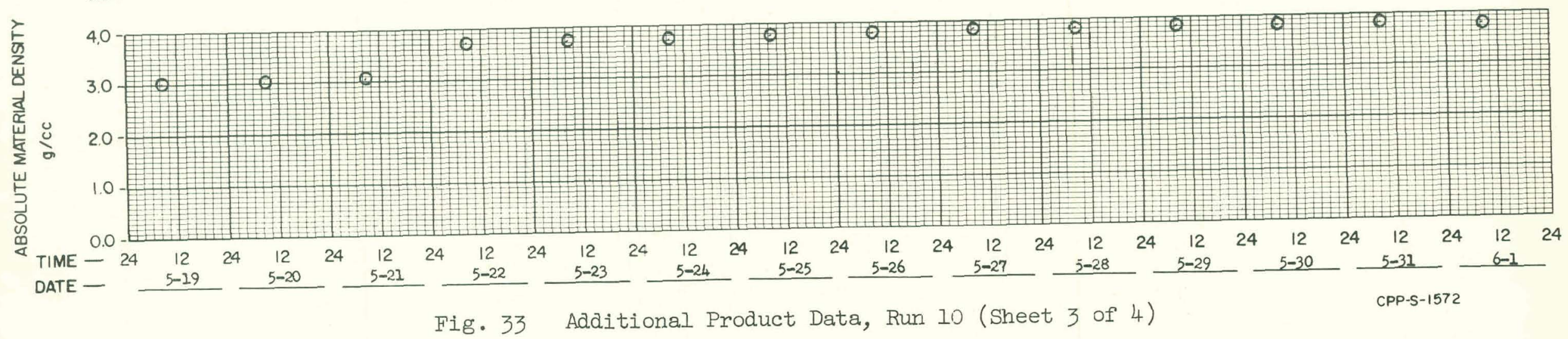


CALCINER Two-foot RUN No. 10

FEED RATE $80,65 \mathrm{l} / \mathrm{hr}$ BED TEMP $500{ }^{\circ} \mathrm{C}$

No. 4 TYPE $1 / 4 \mathrm{~J}$ AIR-TO-4IOUID DRY FINES RETURN_-Nono scfm

SUPERFICIAL FLUIDIZING VELOCITY $0.78 \mathrm{ft} / \mathrm{sec}$
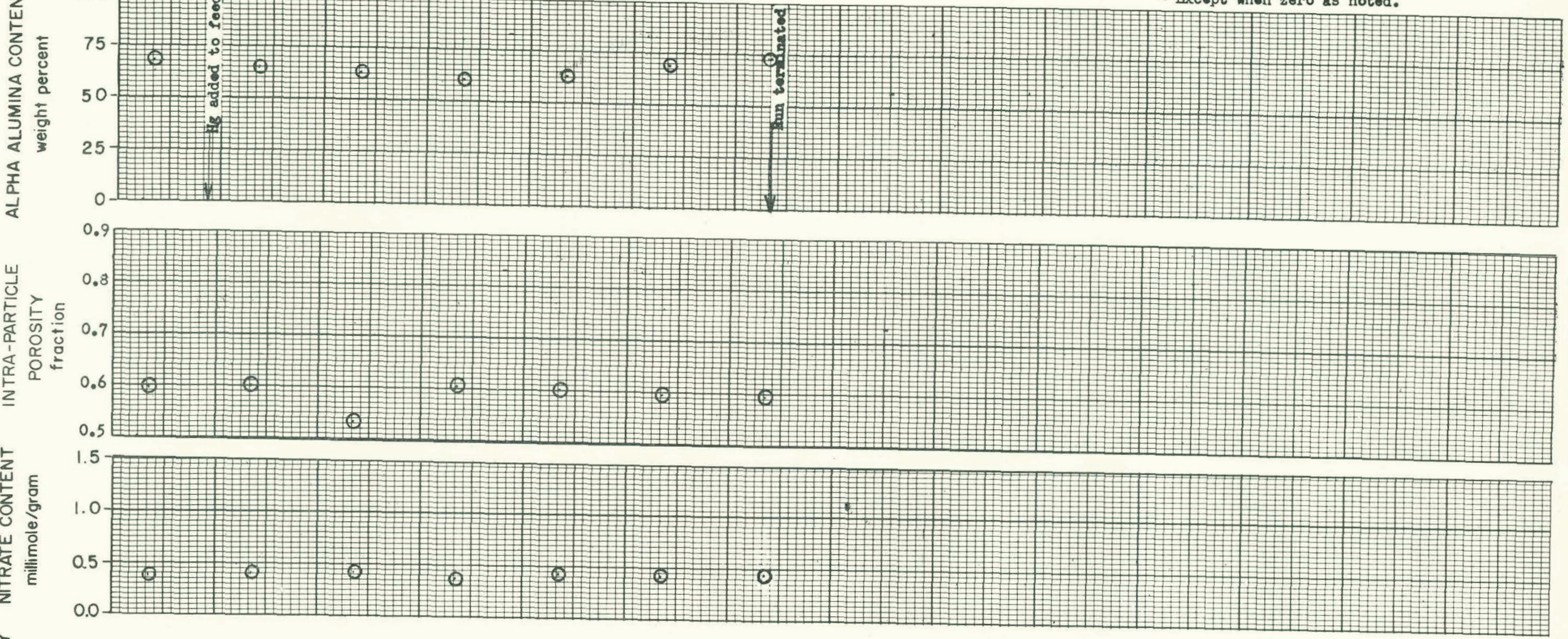

⿹

40

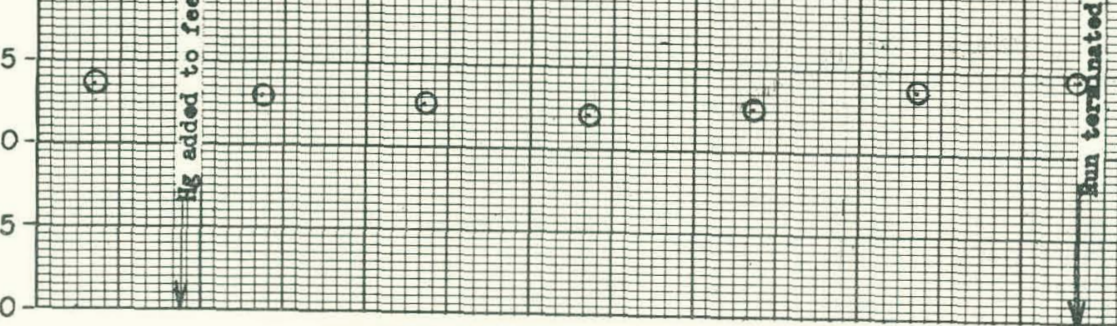

$\mathrm{Al}\left(\mathrm{NO}_{3}\right)_{3} \quad \frac{1.95}{\mathrm{M}} \quad \mathrm{NaNO}_{3} \quad 0.089$

$\mathrm{HNO}_{3} \frac{1.25}{\mathrm{M}} \quad \mathrm{Hg}\left(\mathrm{NO}_{3}\right)_{2} \frac{0.006^{*}}{\mathrm{M}}$

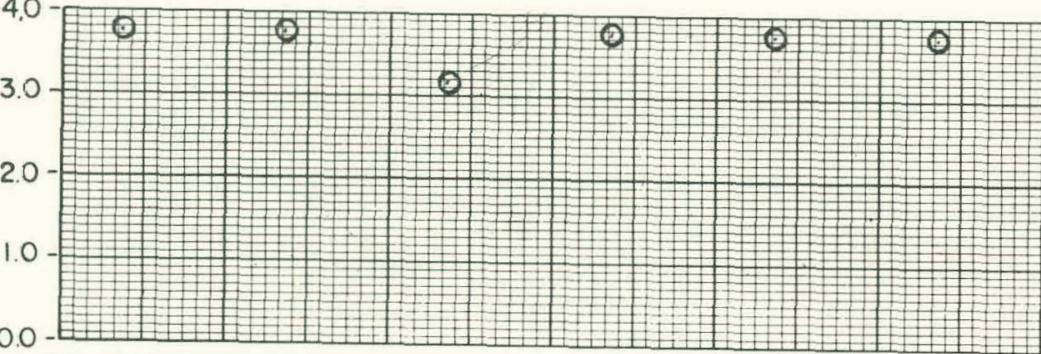

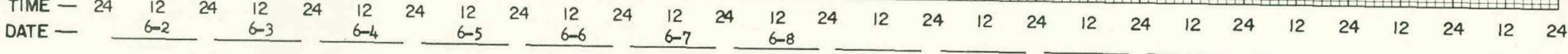


CALCINER Two-Poot RUN No. 10

FEED RATE 80,65 I/ $/ \mathrm{hr}$ BED TEMP. 500

NOZZLES: No. 4 TYPE $1 / 4 \mathrm{~J}$
SUPERFICIAL FLUIDIZING VELOCITY $0.78 \mathrm{f} \$ / \mathrm{sec}$ DRY FINES RETURN Non scfm
FEED:

$\mathrm{Al}\left(\mathrm{NO}_{3}\right)_{3} \quad 1.95 \quad \mathrm{M} \quad \mathrm{NaNO}_{3} \quad 0.089 \quad \mathrm{M}$

$\mathrm{HNO}_{3} \quad \mathrm{H}_{2} 25 \mathrm{M} \quad \mathrm{Hg}\left(\mathrm{NO}_{3}\right)_{2}-0.006$ M

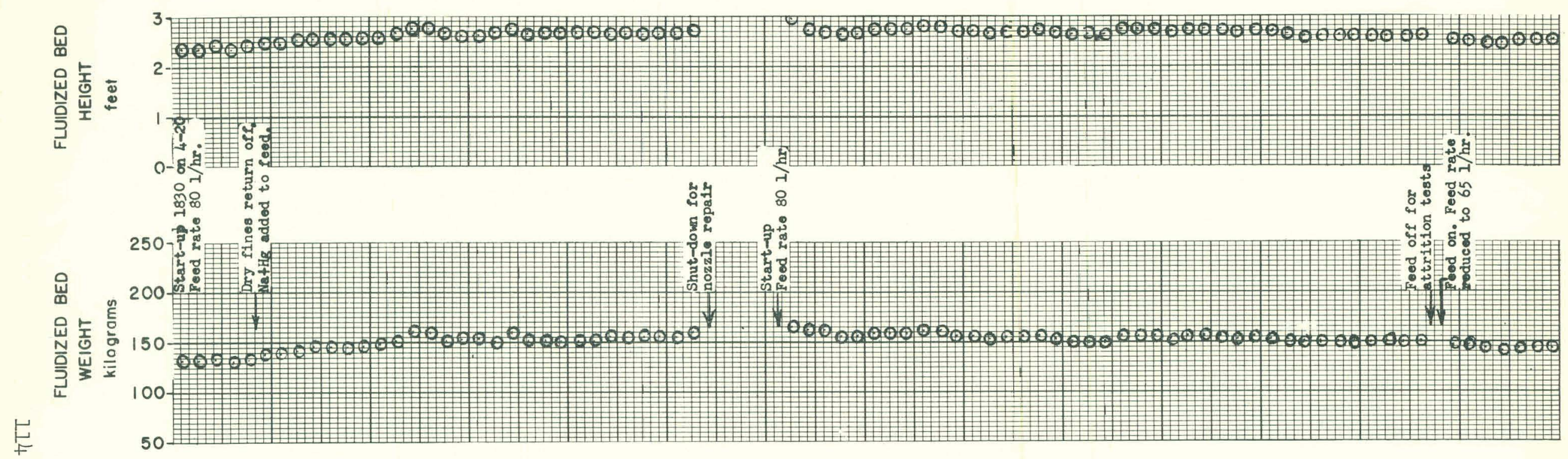

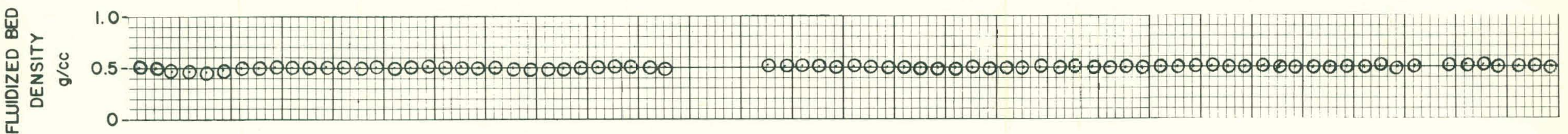

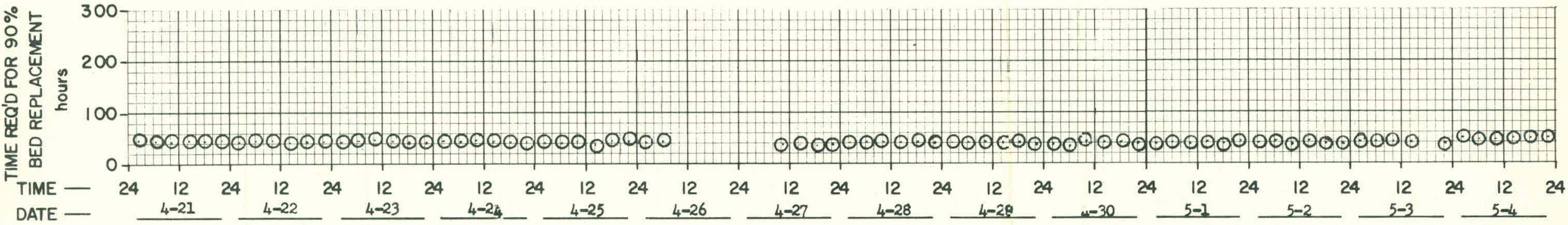

Fig. 34 Calciner Bed Data, Run 10 (Sheet 1 of L) 

CALCINER TWO-Poot RUN No. 10
SUPERFICIAL FLUIDIZING VELOCITY $0.78 \mathrm{ft} / \mathrm{sec}$
FEED RATE $80,65 \mathrm{I} / \mathrm{hr}$ BED TEMP. $500{ }^{\circ} \mathrm{C}$
DRY FINES RETURN None scím
FEED:
NOZZLES: NO. 4 TYPE 282,346 AIR-TO-LIOUID VOLUME RATIO 282;346
$\mathrm{AI}\left(\mathrm{NO}_{3}\right)_{3} \quad 1.95 \mathrm{M}$
$\mathrm{NaNO}_{3}-0.089$

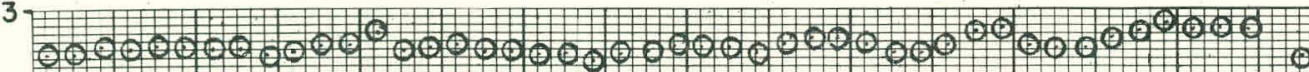
0000000000000000000000000000000

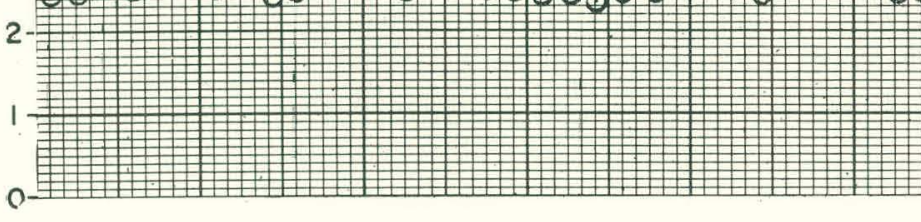

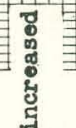
†ैं

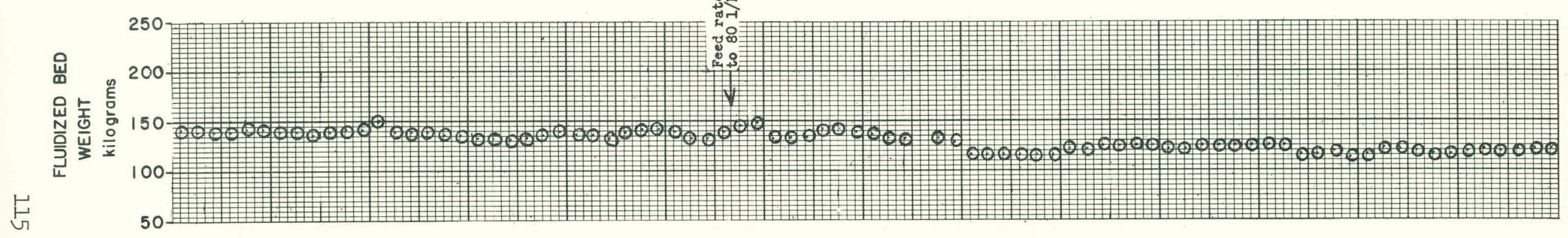

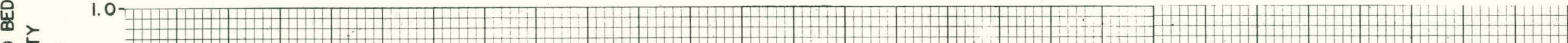

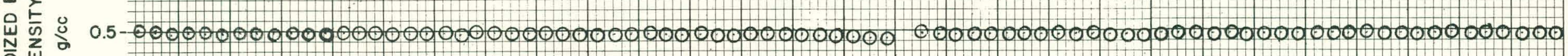

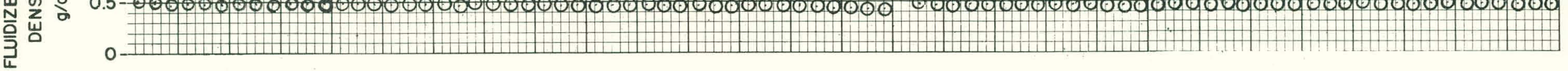

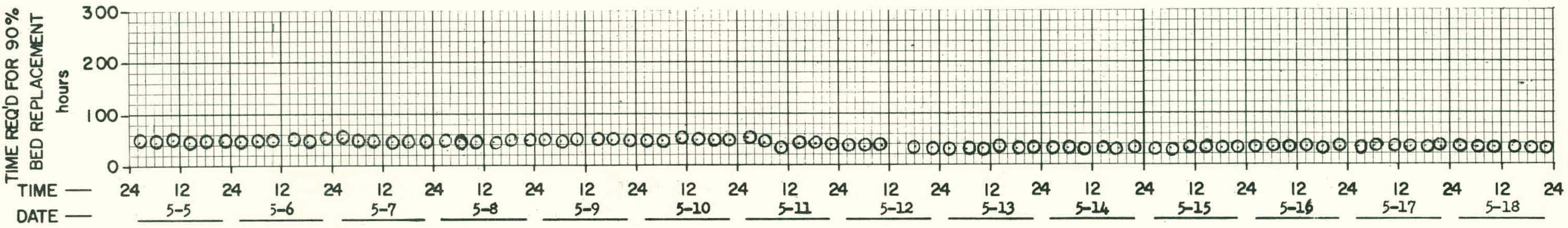


CALCINER Two-10ot RUN No. 10

FEED RATE $80,65 \mathrm{l} / \mathrm{hr}$ BED TEMP $500 \quad{ }^{\circ} \mathrm{C}$

SUPERFICIAL FLUIDIZING VELOCITY $-0.78 \mathrm{ft} / \mathrm{sec}$ NOZZLES: No. 4 TYPE $1 / 4 \mathrm{~J}$ AIR-TO-LIQUID VOLUME RATIO 282:3/46
FEED:

$\mathrm{Al}\left(\mathrm{NO}_{3}\right)_{3}, 1.95 \mathrm{M} \quad \mathrm{NaNO}_{3}-0.089 \mathrm{M}$ $\mathrm{HNO}_{3} \quad 1.25 M \quad \mathrm{Mg}\left(\mathrm{NO}_{3}\right)_{2}-0.006^{*} \mathrm{M}$ * Except when sero as noted.

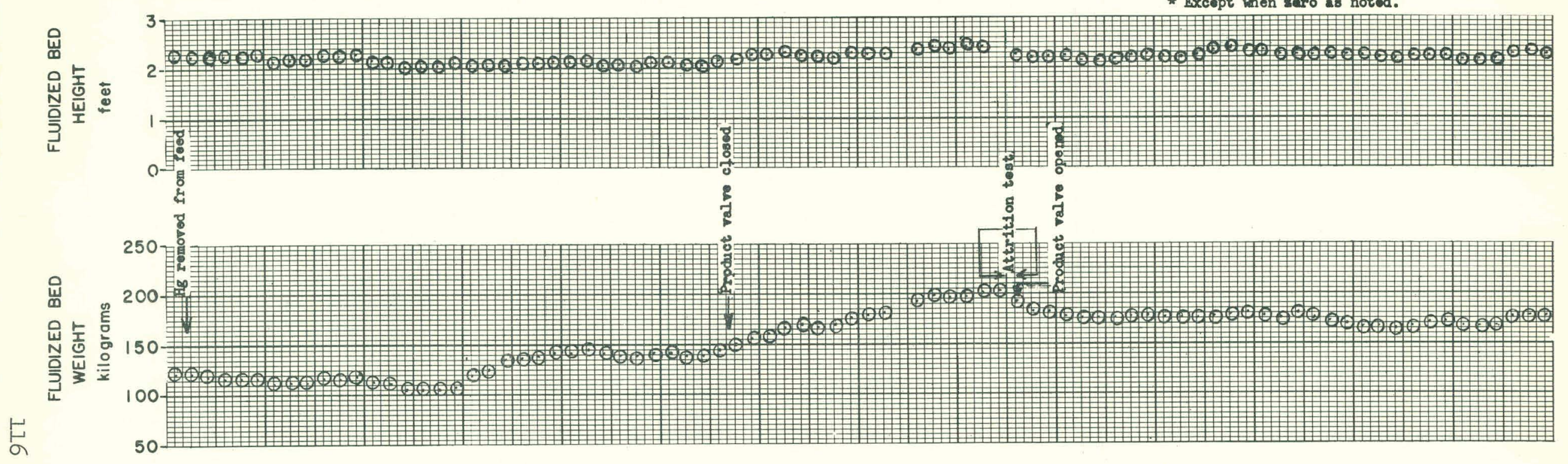

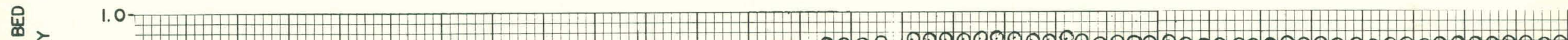

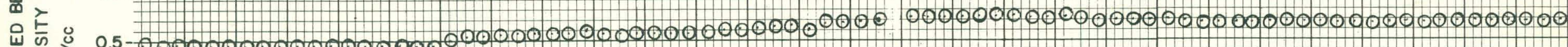

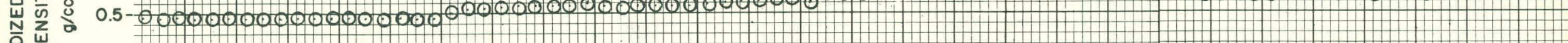

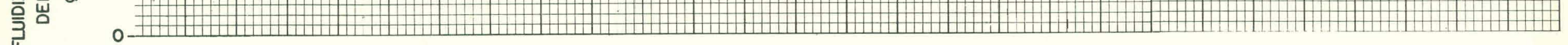

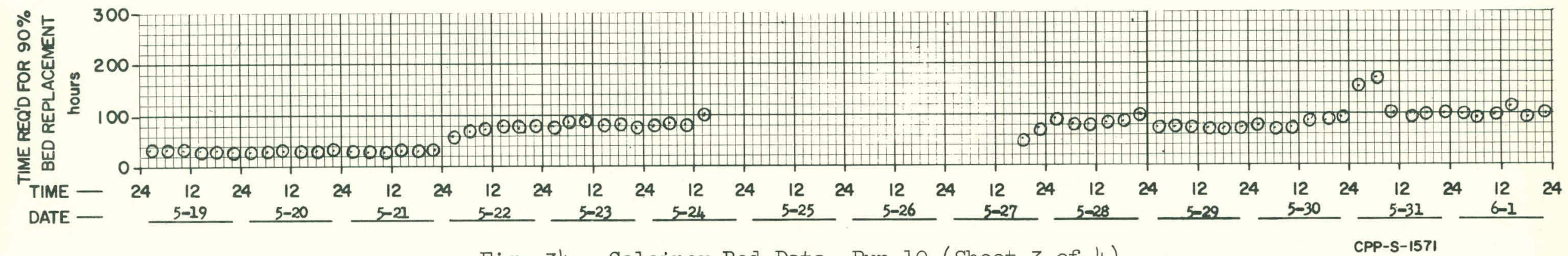

Fig. 34 Calciner Bed Data, Run 10 (Sheet 3 of 4) 


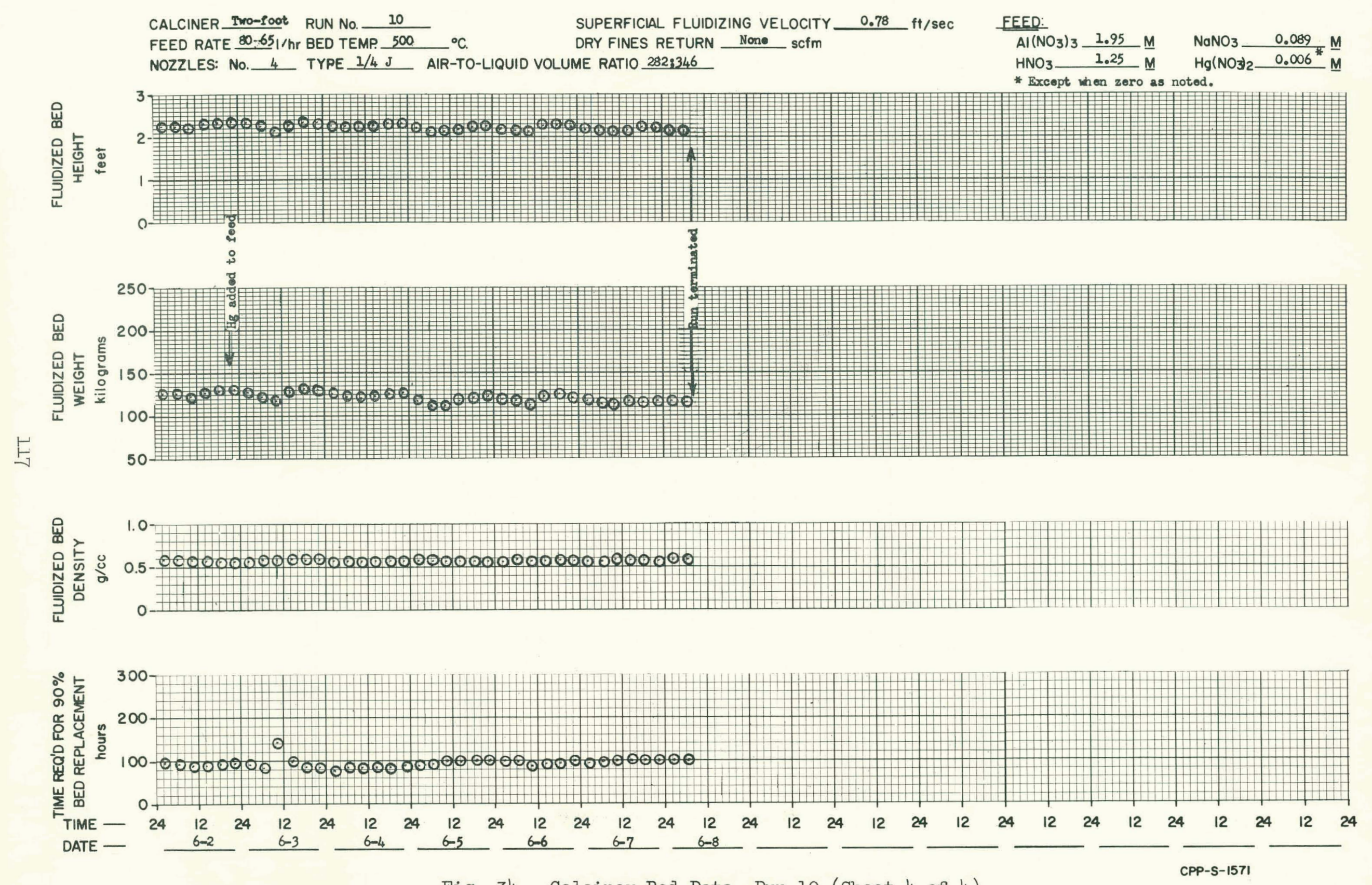

Fig. 34 Calciner Bed Data, Run 10 (Sheet 4 of 4 ) 
CALCINER Two-foot RUN No. 10

FEED RATE $80,65 \mathrm{l} / \mathrm{hr}$ BED TEMP $500{ }^{\circ} \mathrm{C}$

NOZZLES: No. 4 TYPE $1 / 4 \mathrm{~J}$
SUPERFICIAL FLUIDIZING VELOCITY $\quad 0.78 \mathrm{f} \uparrow / \mathrm{sec}$ DRY FINES RETURN None scfm AIR-TO-LIQUID VOLUME RATIO $282 ; 346$
FEED:

$\mathrm{Al}\left(\mathrm{NO}_{3}\right)_{3} \quad 1.95$ M $\quad \mathrm{NaNO}_{3} \quad 0.089 \mathrm{M}$

$\mathrm{HNO}_{3} \quad 1.25 \underline{\mathrm{M}} \quad \mathrm{Hg}\left(\mathrm{NO}_{3}\right)_{2}-0.006 \bar{M}$

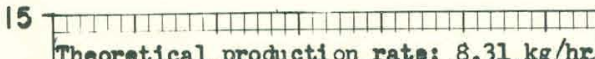

Theorotical production rate: $8.31 \mathrm{~kg} / \mathrm{hr}$

\section{[म[107T]} ont

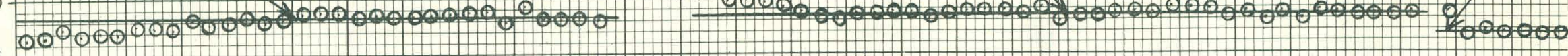

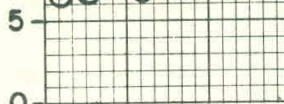
0

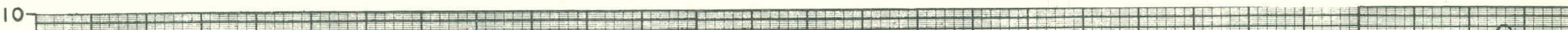

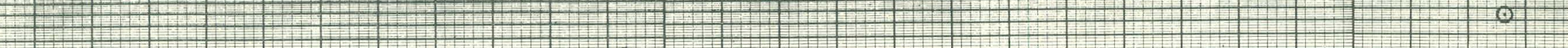

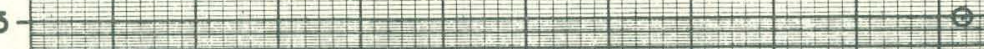

西

1 - 1 -

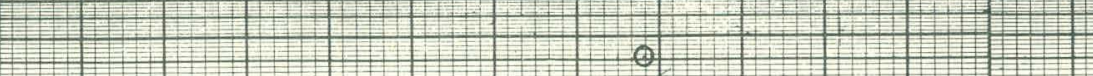

क्ष

证

0.5

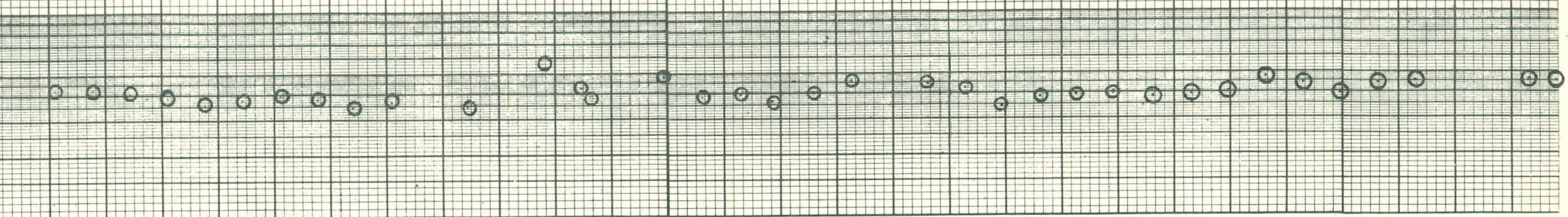

0.1

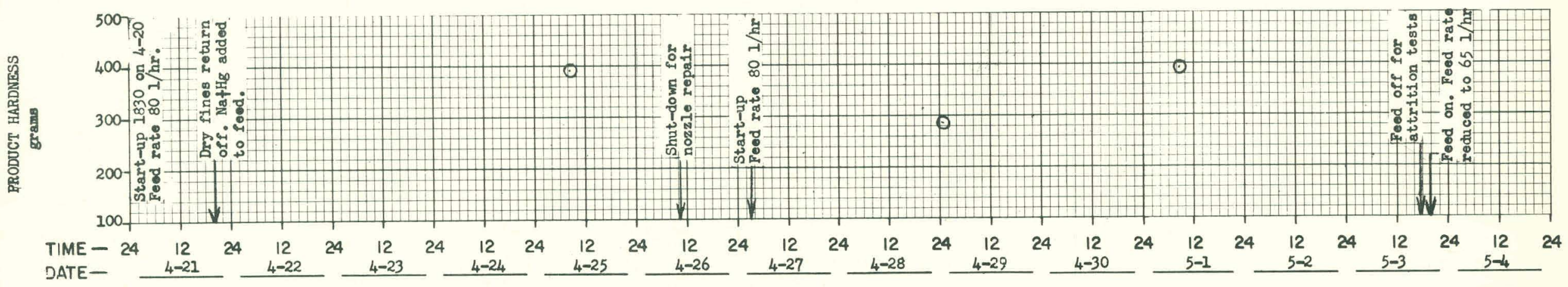

Fig. 35 Gereral Data, Run 10 (Sheet 1 of 4) 
CALCINER Two-Poot RUN No. 10

FEED RATE $\frac{80,65}{1} \mathrm{l} / \mathrm{hr}$ BED TEMP. $500{ }^{\circ} \mathrm{C}$

NOZZLES: NO 4 TYPE $1 / 4 \mathrm{~J}$
SUPERFICIAL FLUIDIZING VELOCITY $0.78 \mathrm{ft} / \mathrm{sec}$

DRY FINES RETURN Nono $8 \mathrm{cfm}$
FEED:

$\mathrm{Al}\left(\mathrm{NO}_{3}\right)_{3}-\frac{1.95}{1.25} \mathrm{M}$

$\mathrm{HNO}_{3}$
$\mathrm{NaNO}_{3}-0.089$

$\mathrm{Hg}\left(\mathrm{NO}_{3}\right)_{2} \stackrel{0.006}{-\mathrm{M}}$

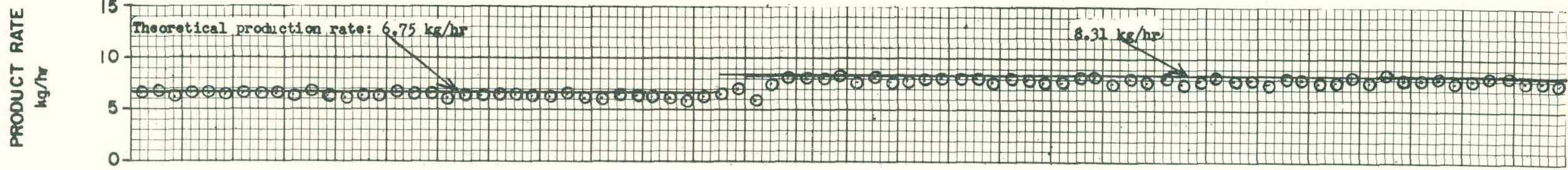
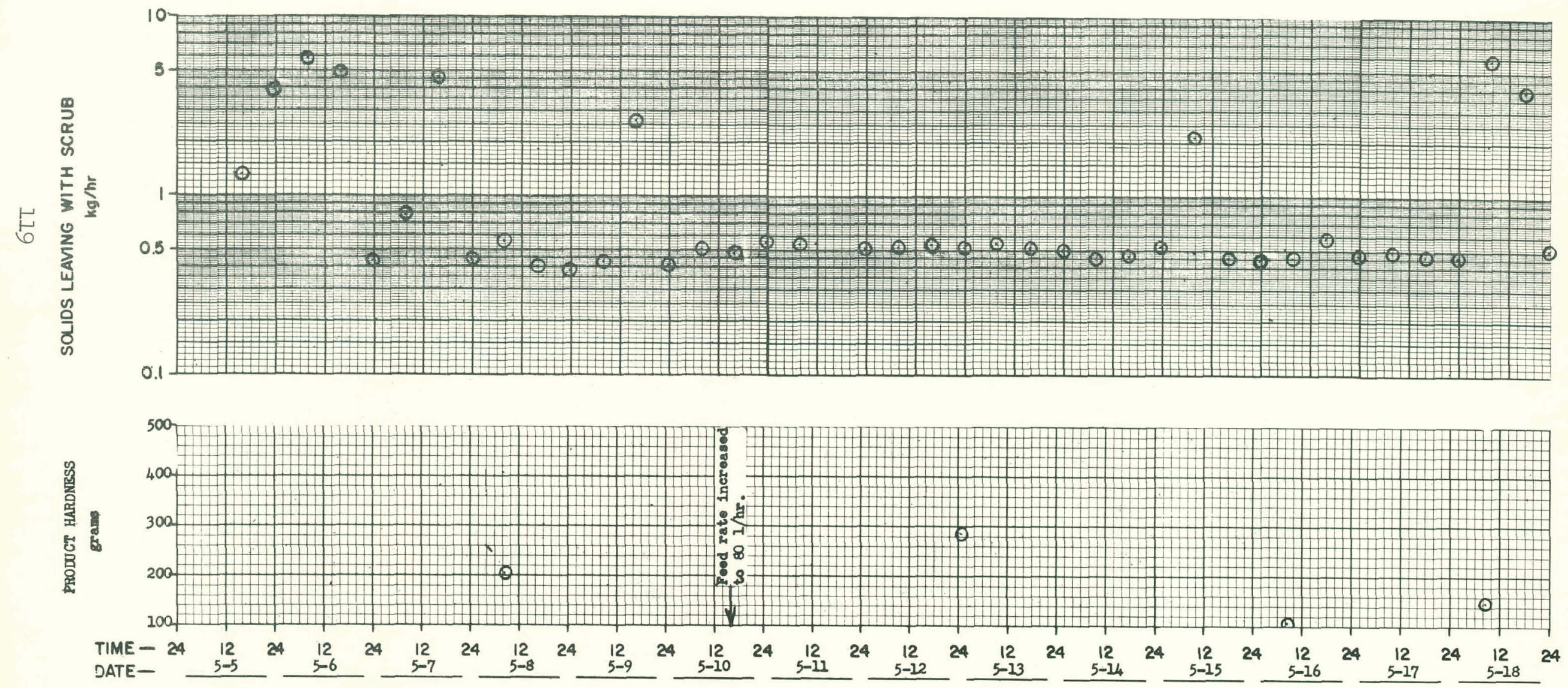

Fig. 35 General Data, Run 10 (Sheet 2 of 4) 
CALCINER TNo-Poot RUN No. 10

FEED RATE $80,65 \mathrm{l} / \mathrm{hr}$ BED TEMP 500 ㅇ

NOZZLES: NO. 4 TYPE $1 / 4 \mathrm{~J}$ DRY FINES RETURN Non

OCITY

is Theorotical production rates $8.31 \mathrm{~kg} / \mathrm{hr}$

$\frac{\omega}{\mathbb{2}}$

5

马

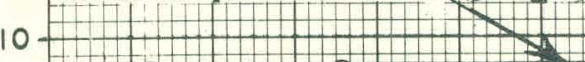

5 .

$0-$

0.77117777
FEED:

$\mathrm{Al}\left(\mathrm{NO}_{3}\right)_{3} \mathrm{l}_{3} .95 \mathrm{M} \quad \mathrm{NaNO}_{3} 0_{0.089} \mathrm{M}$

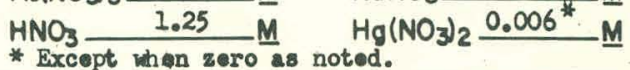

* axcept as noted.

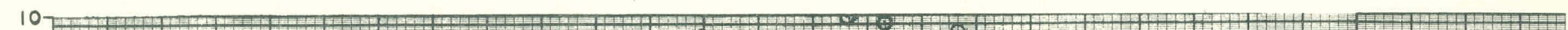

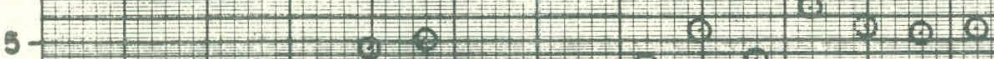
10. 6

点

0.1

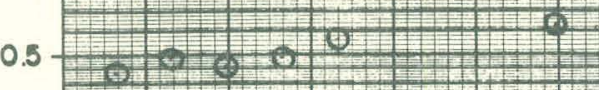

$0+2+1+2+\infty$

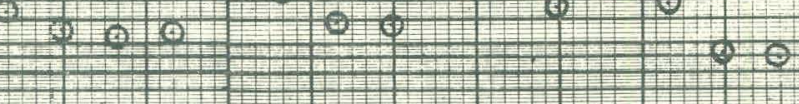
\begin{tabular}{lll}
\hline &
\end{tabular} $+$

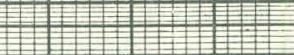
$+\frac{1}{1+10}$

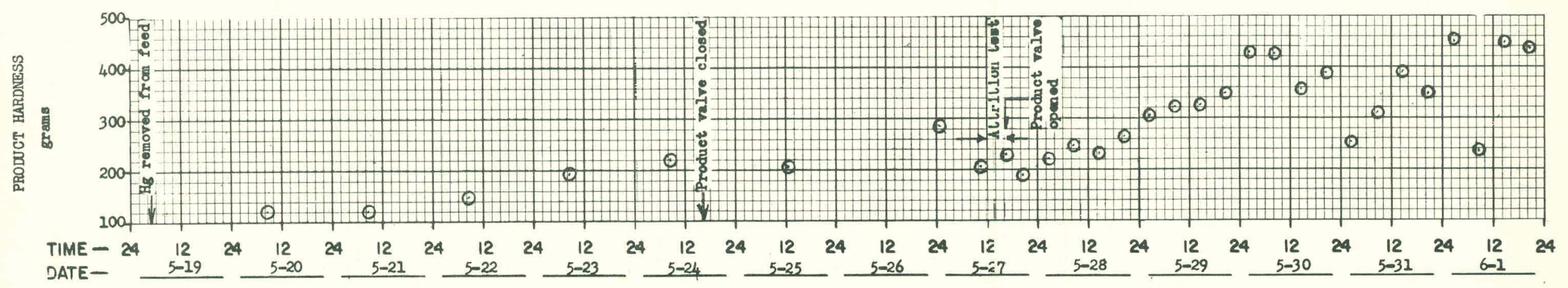

Fig. 35 General Data, Run 10 (Sheet 3 of 4) 
CALCINER Tro-root RUN No. 10 FEED RATE $80,65 \mathrm{l} / \mathrm{hr}$ BED TEMP. $500 \quad{ }^{\circ} \mathrm{C}$

NOZZLES: No. 4 TYPE $1 / 4 \mathrm{~J}$
SUPERFICIAL FLUIDIZING VELOCITY $0.78 \mathrm{ft} / \mathrm{seC}$

DRY FINES RETURN__ _one $8 c f m$
FEED:

$\mathrm{Al}\left(\mathrm{NO}_{3}\right)_{3} \frac{1.95}{\mathrm{M}} \mathrm{NaNO}_{3}-0.089$

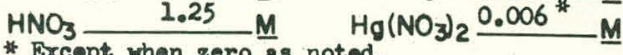
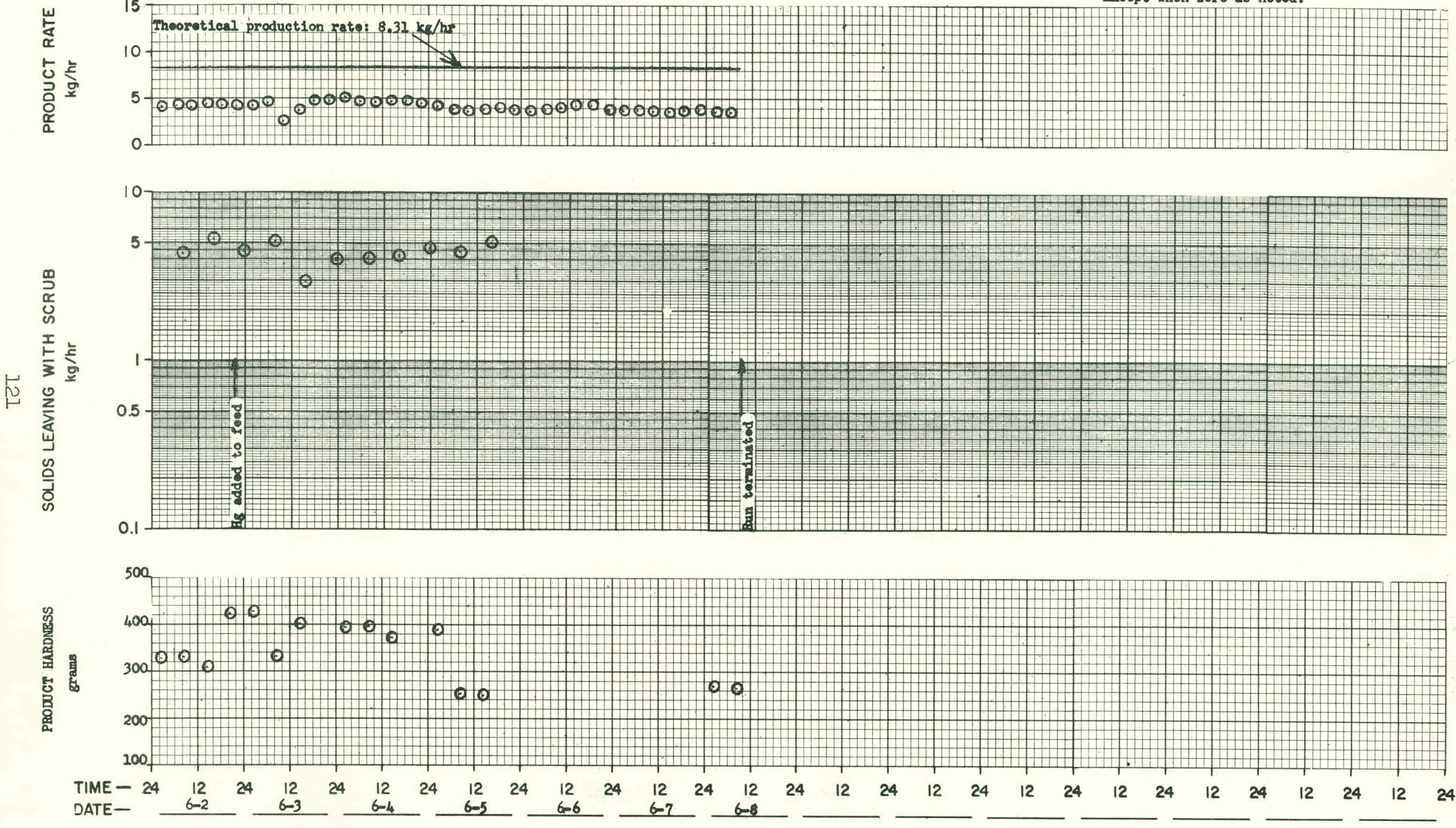

Fig. 35 General Data, Run 10 (Sheet 4 of 4 ) 


\section{PHILLIPS}

\section{PETROLEUM}

COMPANY

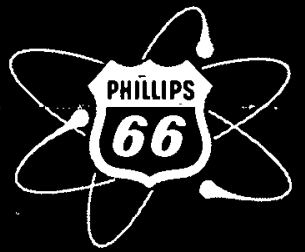

ATOMIC ENERGY DIVISION 